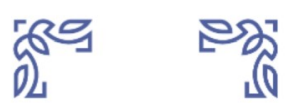 \\ Corvinus \\ \&a
}

\section{WORKITG PAPERS}

CORVINUS UNIVERSITY OF BUDAPEST

CEWP 01/2020

Forecasting exchange rates of major currencies with long maturity forward rates

Zsolt Darvas and Zoltán Schepp

http://unipub.lib.uni-corvinus.hu/5665 


\title{
Forecasting exchange rates of major currencies with long maturity
}

\author{
forward rates \\ Zsolt Darvas ${ }^{\mathrm{a}}$ and Zoltán Schepp ${ }^{\mathrm{b}}$ \\ ${ }^{a}$ Bruegel and Corvinus University of Budapest, e-mail: zsolt.darvas@uni-corvinus.hu \\ bUniversity of Pécs, e-mail: schepp.zoltan@ktk.pte.hu
}

March 30, 2020

\begin{abstract}
This paper presents unprecedented exchange rate forecasting results based upon a new model which approximates the gap between the fundamental equilibrium exchange rate and the actual exchange rate with the long-maturity forward exchange rate. The theoretical derivation of our forecasting equation is consistent with the monetary model of exchange rates. Our model outperforms the random walk in out-of-sample forecasting of twelve major currency pairs in both short and long horizons forecasts for the 1990-2020 period. The results are robust for all sub-periods with the exception of years around the collapse of Lehman Brothers in September 2008. Our results are robust to alternative model specifications, single equation and panel estimation, recursive and rolling estimation, and alternate data construction methods. The model performs better when the long-maturity forward exchange rate is assumed to be stationary as opposed to assuming non-stationarity. The improvement in forecast accuracy of our model is economically and statistically significant for almost all exchange rate series. The model is simple, linear, easy to replicate, and the data we use are available in real time and not subject to revisions.
\end{abstract}

JEL Classification: F31; F37

Keywords: exchange rate; error correction; forecasting performance; monetary model; out-ofsample; random walk 


\section{Introduction}

Forecasting foreign exchange rates is a central issue in international economics and financial market research. Since the seminal work of Meese and Rogoff (1983), hundreds of studies have attempted to outperform the random walk in out-of-sample forecasting with models based on macroeconomic fundamentals. These attempts have been either unsuccessful or if successful, subsequent work has disproved their results. A powerful formulation of the skeptical consensus was presented by Sarno and Taylor (2002) who, after conducting an extensive review of the literature, concluded that "a model that forecasts well for one exchange rate and time period will tend to perform badly when applied to another exchange rate and/or time period" (page 137).

Engel and West (2005) offered a theoretical explanation for this empirical forecasting failure: the exchange rate could be arbitrarily close to a random walk if the fundamentals have a unit root and the factor for discounting future fundamentals is close to one. This result, also emphasized by Engel et al (2007), implies that the out-of-sample forecasting power relative to the random walk is an unreliable gauge for evaluating exchange-rate models.

However, in the past one and a half decades, an increasing number of studies have reported successful forecasting results. These studies can be divided into two groups: theory-oriented works based on fundamental variables, sometimes in a new macroeconomic context, and empirical-oriented research often using $a d$-hoc assumptions and methods.

Theory-oriented approaches include works using models based on Taylor-type fundamentals, which led to successful predictions at the 1-month forecasting horizon (Molodtsova and Pappel, 2009; Ince et al, 2016). The usefulness of the monetary model for longer-horizon forecasts (15 years) has been demonstrated by Engel et al (2007) and Cerra and Saxena (2010) in panel frameworks. Gourichas and Rey (2007) used the net external asset position as a predictor for 1 to 12 quarter horizon forecasts (for weighted-average dollar exchange rates). Ca'Zorzi et al (2017) used a DSGE model to successfully forecast the real exchange rate, but not the nominal exchange rate. Finally, there are works highlighting the distortions of the mean squared forecast error (MSFE) indicator when applied to models with fundamental variables, such as Clark and West (2006 and 2007) and Moosa (2013).

Empirical-oriented approaches do not necessarily rely on a theoretical model, sometimes 
because they criticize the instability of such models. These approaches could be called 'agnostic', and they typically rely on ad-hoc model specifications and/or arbitrary econometric methods to forecast exchange rates. A seminal work employing such an approach was Clarida and Taylor (1997), who used short-term interest rates in a vector error correction framework to forecast exchange rates with some success. Other examples include Engel et al (2015), who used a factor-based panel prediction model; Chinn and Moore (2011), a hybrid model combining the monetary model with order flow variables; Altavilla and De Grauwe (2010), non-linear dynamic models; Wang and Wu (2012), interval projection method; Dal Bianco et al (2012), the use of a Kalman Filter to combine fundamental explanatory variables measured at different frequencies in a factor model; the 'kitchen-sink' regression of Li et al (2015); Berge (2014), who documented the time-varying predictive power of various fundamentals; and works focusing on time-varying parameters, weights or relationships, including Della Corte et al (2009), Wright (2008), Park and Park (2013). There are also studies assessing the efficiency of model-selection approaches, including Sarno and Valente (2009), Brooks et al (2016) and Kouwenberg et al (2017).

In spite of these recent positive forecasting results, survey works continue to be cautious when describing the predictability of exchange rates. Rossi (2013) concluded that "Overall, the empirical evidence is not favorable to traditional economic predictors, except possibly for the monetary model at very long horizons and the UIRP at short horizons, although there is disagreement in the literature" (page 1075) ${ }^{1}$. Engel (2014) discussed the controversy between shorter and longer horizon forecasts and underlines, as one possible explanation, “... even the evidence of long-horizon predictability is not unshakeable ... it may appear that the exchange rate change is forecastable over some periods, but that outcome may simply be luck. The current evidence of long-run forecastability might be overturned" (page 485). The latter conclusion can be viewed as a general criticism of forecasting literature, but is particularly relevant to works using the above-described empirical methods without a clear theoretical framework. Cheung et al (2019) compared eight alternative theory-oriented approaches for five US dollar exchange rates and concluded that "the question of exchange rate predictability (still) remains unresolved", because "a specific model/specification/currency combination may perform well in some periods under a performance metric, it will not necessarily wok well in another period with an alternative performance metric".

\footnotetext{
${ }^{1}$ UIRP $=$ uncovered interest rate parity.
} 
Rossi (2013) further highlighted that predictability of exchange rates depends on: 1) the explanatory variables, 2) the forecast horizon, 3) the sample period, 4) the model used, and 5) the evaluation method. In our interpretation, this can be seen as a multi-dimensional space which includes a number of null hypotheses, among them the following: there is no explanatory variable when used in linear models that delivers consistently positive forecasting results for a wide range of major currencies across various forecast horizons, for long out-of-sample forecast evaluation periods, while being robust to sub-periods and assessment using the toughest MSFE evaluation criterion.

In this paper, we present statistically significant results that challenge the above hypothesis. Using a novel combination of general theoretical exchange rate models as proposed by Engel and West (2005) and the error-correction forecasting equation of Mark (1995), we show longmaturity forward exchange rates can be taken as a proxy for the difference between the fundamental equilibrium and the current exchange rate. We therefore derive a simple forecasting equation where the change of exchange rate is regressed on the previous period's long-maturity theoretical forward exchange rate. While the empirical literature on uncovered interest rate parity (UIP) concludes that forward rates are not unbiased predictors of exchange rates, they can be used efficiently, in our error correction framework, to forecast future exchange rate changes for both short and long forecast horizons.

Our forecasting model leads to forecasts more accurate than the random walk in the January 1990 - February 2020 out-of-sample forecasting evaluation period, for major currencies, for all forecasting horizons between 1 month and 5 years, using four different forecast evaluation criteria. These results are unprecedented. While past works have shown better than randomwalk forecasts in some cases, our results show a Pareto-improvement relative to these. That is, our results are improved in at least one, and in most cases several, important aspects without sacrificing any other aspect. For example, some works report superior one-period-ahead forecasts, but not longer-horizon forecasts, and others the reverse. Our forecasts beat the random walk both in short and long-horizon forecasts. We use more currencies, longer out-of-sample forecasting periods and more forecast evaluation criteria than most relevant previous works. Furthermore, we test the robustness of our results using various sub-periods between 1990 and 2020 and find superior forecasting results with the exception of a few years around the collapse of Lehman Brothers in September 2008, a period when exchange rates and interest rates behaved erratically. After currency markets stabilized, our forecasting results were again strong. We apply a very large number of robustness tests which all support our strong forecasting 
results.

Our forecasts have outstanding properties when applying simple ordinary least squares (OLS) separately for each currency pair and also in panel models. In the OLS framework, the number of parameters to estimate varies from four to eight and no specification search is needed. The simplicity of our models makes the replication of our results easy, in contrast to several works, which require the estimation of large numbers of parameters and/or a time-consuming process of model selection and estimation.

We do not use long-horizon regressions (in which the multi-period ahead change in exchange rate is regressed on explanatory variables) and therefore our forecasting model is not subject to "overlapping observation" issues, as discussed by Berkowitz and Giorgianni (2001), Rossi (2007) and Darvas (2008). Instead, our longer-horizon forecasts are based on the iteration of one-period forecasts.

Also, data revision is not an issue for our model. For example, Faust et al (2003) criticized the favorable findings of Mark (1995), arguing that forecasting results depend on the data vintage used to construct explanatory variables. In contrast, the only explanatory variable included in our model is the theoretical forward exchange rate, which we calculate from the spot exchange rate and the interest rates of the two countries. These data are available in real time and are not revised.

The rest of the paper is organized as follows. Section 2 presents the theoretical framework used to derive our forecasting equation, while the model is described in section 3 . Section 4 introduces the data and results from some preliminary data analysis, section 5 presents our outof-sample forecasting results, and section 6 presents a brief conclusion. Because of space constraints and the large number of robustness tests performed, we report detailed results for the most-traded currency pair, the US dollar and the Deutsche mark (for the Deutsche mark, we use the euro rate since 1999). This currency pair accounted for one-quarter of total global foreign exchange market turnover over 1992-2019 according to the triennial surveys of BIS, with a \$1584 billion average daily turnover in April 2019 (BIS, 2019). Summary results, along with several robustness tests, are presented for eight other US dollar rates and three other mosttraded Deutsche mark (euro) rates, the Japanese yen, the British pound sterling and the Swiss 
franc rates. Detailed results for these currency pairs are available in the appendices ${ }^{2}$.

\section{Theoretical framework}

Mark (1995) considered the following general error correction model for exchange rate forecasting, based on theoretical models involving fundamental determinants of exchange rates, such as the monetary model:

$$
s_{t+k}-s_{t}=\alpha_{k}+\beta_{k} \cdot\left(f_{t}-s_{t}\right)+\varepsilon_{t+k, k},
$$

where $s_{t}$ is the logarithm of the spot exchange rate, $f_{t}$ is the logarithm of the fundamental equilibrium value of the exchange rate, $\alpha_{k}$ and $\beta_{k}$ are model parameters, and $\varepsilon_{t+k, k}$ is the $k$ period ahead forecast error.

According to this approach, exchange rate changes could be forecast using the difference between the fundamental and actual values of the exchange rate, thereby assuming an error correction mechanism. Papers using this approach typically estimate $f_{t}$ from a theoretical exchange rate model. We follow a different approach by approximating the difference between the fundamental equilibrium and actual exchange rates $\left(f_{t}-s_{t}\right)$, which is the long-maturity theoretical forward exchange rate multiplied by a scalar, as we demonstrate below.

We start with the key equation of Engel and West (2005), who analyzed a general class of theoretical exchange rate models in a rational expectation, present-value framework (see equation (2) in Engel and West, 2005). Engel (2014) presented the simplified version of this key equation (see equation (45) in Engel, 2014) as:

$$
s_{t}=(1-b) \cdot f_{1 t}+b \cdot f_{2 t}+b \cdot E_{t}\left[s_{t+1}\right],
$$

where $f_{1 t}$ and $f_{2 t}$ are the convex combinations of exchange-rate fundamentals, parameter $b$ is the discount factor, which falls in the range $0<b<1$, and $E_{t}[$. $]$ denotes the expectations operator. Engel and West (2005) show the exchange rate follows a random walk for a discount factor $b$ that is near 1 if $f_{2 t}$ has a unit root, or $f_{2 t}=0$ and $f_{1 t}$ has a unit root.

Engel and West (2005) demonstrated that when purchasing power parity holds and parameters of the money demand functions are identical in the two countries considered, a large class of

\footnotetext{
${ }^{2}$ An earlier version of this paper, which reported similarly excellent forecasting results for a shorter out-of-sample evaluation period (1990-2006), for nine USD dollar exchange rates, using one forecast evaluation criteria, yet without a proper theoretical motivation and robustness checks, is Darvas and Schepp (2007).
} 
money income models can be written in the following form (see equation (7) in Engel and West, 2005):

$$
s_{t}=\frac{1}{1+\alpha}\left[m_{t}-m_{t}^{*}-\gamma\left(y_{t}-y_{t}^{*}\right)+q_{t}-\left(v_{t}-v_{t}^{*}\right)-\alpha \rho_{t}\right]+\frac{\alpha}{1+\alpha} E_{t}\left[s_{t+1}\right],
$$

where $m_{t}$ denotes the logarithm of domestic money supply, $y_{t}$ the logarithm of domestic income, $q_{t}$ the real exchange rate, $v_{t}$ the home shocks to money demand ${ }^{3}$ and $\rho_{t}$ is the risk premium. Foreign variables are denoted with *. $\alpha$ denotes the interest semi-elasticity of money demand multiplied by -1 and $\gamma$ denotes the income elasticity of money demand.

Following Engel and West (2005), we define three simple substitutions:

(4a) $f_{1 t}=\left[m_{t}-m_{t}^{*}-\gamma\left(y_{t}-y_{t}^{*}\right)+q_{t}-\left(v_{t}-v_{t}^{*}\right)\right]$

(4b) $f_{2 t}=-\rho_{t}$

(4c) $\quad b=\frac{\alpha}{1+\alpha}$

Using (4a), (4b) and (4c), we can write (3) in the general form of (2). It may seem that unobserved variables, $\rho_{t}, E_{t}\left[s_{t+1}\right]$ and $v_{t}$ via $f_{1 t}$, are multiplied by $b$. We address this issue through use of the following definitions:

$$
\begin{aligned}
& -\rho_{t}=\tilde{i}_{t}^{(1)}-\left(E_{t}\left[s_{t+1}\right]-s_{t}\right), \\
& d_{t}^{(1)}=s_{t}+\tilde{i}_{t}^{(1)},
\end{aligned}
$$

where $\tilde{i}_{t}^{(1)}$ is the logarithmic interest rate differential and $d_{t}^{(1)}$ is the theoretical 1-period ahead forward exchange rate. Equation (5) is identical to equation (1) in Engel (2014), while equation (6) is the standard definition of the theoretical forward rate after taking $\operatorname{logs}{ }^{4}$. We use the theoretical (rather than actual) forward rate as our derivations call for. The theoretical forward exchange rate is equal to the actual forward exchange rate if covered interest party (CIP) holds.

\footnotetext{
${ }^{3}$ Engel and West (2005, page 492) interpreted money demand shocks in the following way: "Our "shocks" potentially include constant and trend terms, may be serially correlated, and may include omitted variables that in principle could be measured."

${ }^{4}$ Equation (6) is the logarithm of $D_{t}^{(1)}=S_{t} \cdot\left(1+i_{t}^{(1)}\right) /\left(1+i_{t}^{(1) *}\right)$, where $D_{t}^{(1)}$ is the level of the 1-period forward rate, $S_{t}$ is the level of the spot exchange rate, $i_{t}^{(1)}$ and $i_{t}^{(1) *}$ are the domestic and foreign 1-period interest rates measured at the frequency of the data (e.g. a 4 percent annual interest rates corresponds to approximately 1 percent at the quarterly frequency). Thereby, $\tilde{i}_{t}^{(1)}=\ln \left(\left(1+i_{t}^{(1)}\right) /\left(1+i_{t}^{(1) *}\right)\right)$.
} 
However, since the theoretical forward exchange rate is part of our derivation and the theoretical forward exchange rate is used in our empirical analysis, it is not necessary for CIP to hold, nor is a liquid market required, for example, for the 10-year maturity actual forward exchange rate.

Using (5) and (6), (4b) can be rewritten as:

$$
f_{2 t}=d_{t}^{(1)}-E_{t}\left[s_{t+1}\right] .
$$

By substituting (7) into (2) we have:

$$
s_{t}=(1-b) \cdot f_{1 t}+b \cdot d_{t}^{(1)}
$$

It is important to highlight that while two unobserved variables, $\rho_{t}$ and $E_{t}\left[s_{t+1}\right]$, were multiplied by $b$ in equation (2), in equation (8) they are replaced by the theoretical forward rate, which is easily calculated from observed variables, the exchange rate and interest rates.

By rearranging equation (8), we see that the difference between the fundamental (multiplied by a scalar) and the spot exchange rate is negatively associated with the one-period ahead theoretical forward exchange rate:

$$
(1-b) \cdot f_{1 t}-s_{t}=-b \cdot d_{t}^{(1)} \text {. }
$$

When we consider relatively high frequency data and correspondingly short maturity interest rates and forward exchange rates, 1 month or 1 quarter, the discount factor $b$ could be close to 1, according to Engel and West (2005).

However, with a smaller (but strictly positive) $b$, the left side of equation (9), $(1-b) \cdot f_{1 t}-s_{t}$, becomes more similar to the regressor in equation (1), $f_{t}-s_{t}$. Our main parameter of interest is $b$ when we consider longer maturity forward rates, which are defined as:

$$
d_{t}^{(h)}=s_{t}+h \cdot \tilde{i}_{t}^{(h)},
$$

where $h$ is the maturity and $\widetilde{i}_{t}^{(h)}$ is the logarithmic $h$-period interest rate differential ${ }^{5}$.

\footnotetext{
${ }^{5}$ Equation (10) is the logarithm of $D_{t}^{(h)}=S_{t} \cdot\left(\left(1+i_{t}^{(h)}\right) /\left(1+i_{t}^{(h) *}\right)\right)^{h}$, where $D_{t}^{(h)}$ is the level of the $h$-period forward rate, $S_{t}$ is the level of the spot exchange rate, $i_{t}^{(h)}$ and $i_{t}^{(h) *}$ are the domestic and foreign $h$-period interest rates measured at the frequency of the data and $h$ indicates the maturity measured as the number of periods in the data frequency. For example, for the 5-year forward rate when using monthly frequency, interest rates have to be converted to the monthly frequency and $h=60$. Equivalently, the interest rate could be measured at the annual frequency as it is standard in everyday practice, in which case $h$ measures the number of years.
} 
As can be seen in (4c), the discount factor $b$ is a function of $\alpha$, the interest rate semi-elasticity of money demand (multiplied by minus one). As Engel and West (2005) highlighted, the empirical estimates of $\alpha$, which are typically based on annualized interest rates expressed as percentages, need to be adjusted for the calculation of $b$ corresponding to the data frequency used $^{6}$. Engel and West (2005) used quarterly frequency. They considered the estimates presented in the seminal works of Bilson (1978), Frankel (1979) and Stock and Watson (1993), and calculated a range of 29-60 for $\alpha$, implying a range of $0.97-0.98$ for $b$, which is fairly close to one.

The estimates for $\alpha$ also need to be adjusted if we consider low frequency data, with more than one year between observations. Assuming a linear approximation, 5-year intervals imply onefifth of the estimated annual semi-elasticity, while 10-year intervals imply one-tenth. The estimates of Bilson (1978), Frankel (1979) and Stock and Watson (1993) would imply a range of 0.42-0.6 for $b$ at the 10-year data frequency when using the 10-year forward looking theoretical forward rate. This magnitude is still relatively large, though not close to 1 . More recent research suggests considerably lower (in absolute terms) estimates for the annual interest rate semi-elasticity of money, leading to lower values for $b$. For example, the estimates of Ireland (2009), Ball (2011) and Jawadi and Sousa (2013) imply a range of 0.09-0.33 for $b$ at the 10-year data frequency, while at the quarterly frequency the range remains relatively high, between $0.8-0.95$. We therefore conclude that the value of $b$ is lower when one considers lower frequency data with corresponding long maturity forward rates. For relatively long horizons such as 5 or 10 years, $b$ could be relatively close to zero.

While the left side of equation (9), $(1-b) \cdot f_{1 t}-s_{t}$, will not became identical to the regressor in equation (1), $f_{t}-s_{t}$, when $b>0$, a $b$ close to zero makes the two expressions similar. Thereby, $d_{t}^{(1)}$ (multiplied by the small but positive $b$ and by minus 1 ) is a good proxy for $f_{t}-$ $S_{t}$.

To gauge the usefulness of this approximation, we calculate correlation coefficients between $s_{t+1}-s_{t}$ and $d_{t}^{(1)}$ for different data frequencies from one month to five years. When $d_{t}^{(1)}$ correlates well with $f_{t}-s_{t}$, we expect a large (in absolute terms) correlation between $d_{t}^{(1)}$ and $s_{t+1}-s_{t}$ according to equation (1), which should have a negative sign according to equation (9). For the one-month data frequency we use the one-month theoretical forward rate, for the

\footnotetext{
${ }^{6}$ See the discussion on page 497 of Engel and West (2005) and in particular footnote 2.
} 
three-month data frequency we use the three-month forward rate, and so on. Since our underlying data is monthly, we can create alternative (non-overlapping) data samples for these calculations ${ }^{7}$. For example, for the quarterly frequency, we could use either the first months of each quarter, or the second months of each quarter, or the third months of each quarter. For the annual frequency, we could consider any of the 12 months of a year. For the three-year frequency we could consider 36 alternatives, and for the five-year frequency 60 alternatives, based on our underlying monthly dataset. In order examine the sensitivity of the estimated correlation coefficients to alternative data sampling, we consider all alternatives based on our monthly dataset and report the minimum, the maximum and the average of the correlation coefficients.

Table 1 shows a spectacular increase (in absolute value) of the correlation between the theoretical forward rate and the one-period ahead change in the exchange rate as we lengthen the time period between two observations and consider correspondingly longer maturity forward rates. At the monthly frequency, the correlation coefficient is just -0.081 . But when sampling data every fifth year and considering the five-year maturity forward rate, the average correlation coefficient is almost 10 -times larger at -0.795 . The tendency is the same for currency pairs other than German mark/US dollar.

When approximating $f_{t}-s_{t}$ with $d_{t}^{(1)}$ in equation (1), the one-period ahead forecasting equation becomes:

$$
s_{t+1}-s_{t}=\alpha_{1}+\beta_{1} d_{t}^{(1)}+\varepsilon_{t+1,1}
$$

Since $d_{t}^{(1)}$ has a negative parameter in equation (9), we expect a negative parameter for $\beta_{1}$.

We could use (11) for one-period ahead forecasts at the data frequency that corresponds to the maturity of the forward rate. For example, if we use the 5-year maturity forward rate, we could sample our data in every fifth year and calculate one-period ahead (5 year) forecasts. However, we are also interested in applying the long maturity forward rates to calculate short horizon forecasts, e.g. using the 5-year forward rate to make a 1-month ahead forecast:

$$
s_{t+1}-s_{t}=\alpha_{1}+\beta_{1} d_{t}^{(h)}+\varepsilon_{t+1,1}
$$

\footnotetext{
${ }^{7}$ Our monthly dataset is constructed using end-of-month data. We could also construct alternative versions for the monthly frequency by considering other days within a month, such as the first days of each month, or the second days of each month, and so on.
} 
when the data frequency is monthly and $h=5$ years.

\section{Our forecasting model}

Equation (1) with $k>1$ belongs to the family of long-horizon regressions, leading to "overlapping observations", which poses immense econometric problems, as discussed by Berkowitz and Giorgianni (2001), Rossi (2007) and Darvas (2008). In addition, such longhorizon regressions lead to information losses for two reasons. First, when forming out-ofsample forecasts from period $t$ to period $t+k$, the estimation sample takes into account information contained in the explanatory variable only up to period $t$ - $k$. Thereby, potentially important information between $t-k$ and $t-1$ is not taken into account in the forecast. Second, when the explanatory variable, that is, $f_{t}-s_{t}$ in equation (1) and $d_{t}^{(h)}$ in equation (12), is stationary, the explanatory variable is expected to converge to its stationary mean in the forecast period and the speed of this convergence will also influence the forecast of $s_{t+k}$. The longhorizon regression does not take this information into account.

We therefore restrict our attention to the case of $k=1$ at the monthly frequency which can produce only one-period ahead forecasts. We set up a very simple two-equation model and iterate one-period ahead forecasts for longer out-of-sample forecast horizons:

$$
\begin{aligned}
s_{t+1}-s_{t} & =\theta_{1}+\theta_{2} \cdot d_{t}^{(h)}+\varepsilon_{t+1,1}^{(1)}, \\
d_{t+1}^{(h)} & =\theta_{3}+\theta_{4} \cdot d_{t}^{(h)}+\varepsilon_{t+1,1}^{(2)},
\end{aligned}
$$

where $\theta_{1}, \theta_{2}, \theta_{3}$ and $\theta_{4}$ are parameters and $\varepsilon_{t+1,1}^{(1)}$ and $\varepsilon_{t+1,1}^{(2)}$ are the error terms.

This model is not estimated on overlapping samples and thereby avoids all problems associated with long-horizon regressions. It includes only four parameters that we estimate with OLS. We do not perform any specification search, though one might check if longer lags for $d_{t}^{(h)}$ in the second equation help forecasting. We consider alternative values for $h: 3$ years, 5 years and 10 years. Thus, our model is simple and replication of our results is very easy.

For comparison we also report forecast errors using the forward rate itself as the prediction, because our models use the long-maturity forward rate as the predictive variable, and the hypothesis of long horizon uncovered interest rate parity (UIP) is well supported by some papers (Chinn and Meredith, 2005; Chinn and Quayyum, 2012). We highlight that our forecasts are based on model (13), and thereby our forecasts are not necessarily - in practice never - equal 
to the forward rate itself. Consequently, our forecasts differ from the prediction of uncovered interest rate parity.

\section{Data and some empirical preliminaries}

\subsection{Data}

Our aim is to test the forecasting performance of our model for the most-traded global currency pairs, for which the underlying assumptions of the monetary model could be valid. We consider the US dollar against the following nine currencies (in brackets we indicate the abbreviation of the currency pair and show the share of these currency pairs in global foreign exchange market turnover in 1992-2019 $)$ ): German mark (DEM/USD, 25.1\%), British pound sterling (GBP/USD, 9.7\%), Japanese yen (JPY/USD, 17.3\%), Swiss franc (CHF/USD, 4.4\%), Canadian dollar (CAD/USD 3.8\%), Australian dollar (AUD/USD, 4.7\%), New Zealand dollar (NZD/USD 1.6\%), Norwegian krone (NOK/USD, 1.0\%), Swedish krona (SEK/USD, 1.3\%). We also study three exchange rates relative to the German mark: the Japanese yen (JPY/DEM, 2.5\%), the British pound sterling (GBP/DEM, 2.2\%) and the Swiss franc (CHF/DEM, 1.5\%). For the German mark we rescale the euro exchange rate from 1999 using the fixed conversion exchange rate. We continue to use German interest rates rather than an average euro interest rate because the latter has been influenced by default risk and euro-exit risk after 2008 . We do not include other euro-area countries, since they share the same currency with Germany since 1999 and their exchange rates were closely tied to the German mark before 1999. We also exclude Denmark, because its currency is pegged to the euro. On average in 1992-2019, the twelve currency pairs we consider accounted for $75 \%$ of global foreign exchange market

\footnotetext{
${ }^{8}$ The BIS triennial surveys measure foreign exchange turnover in April of every third year between 1992 and 2019: we calculate the average of percentage shares reported by the surveys. Turnover data for the Swedish krona rate to the US dollar is available from 2007, for the New Zealand dollar and Norwegian krone rates to the US dollar from 2013, and for the yen rate against the euro from 2001.
} 
turnover ${ }^{9}$.

The sample includes monthly data from January 1979 to February 2020, although some interest rate series are available only starting in the mid-1980s. Hence, our sample includes countries with floating exchange rates over the entire sample period (Germany, UK, Japan, Canada), but also countries that moved from a pegged to floating regime (Australia and New Zealand in the mid-1980s, Norway and Sweden in the early 1990s). Switzerland had a freely floating exchange during most of our sample period, with the exception of 2011 to 2015.

We collected end-of-month data, which is available for all exchange rates, for German, UK and US interest rates in our full period, and for interest rates of other countries staring from the late 1980s or early 1990s. For these other countries, interest rate data for the preceding period is available as a monthly average. The combination of end-of-month and monthly average data could lead to inconsistency. However, in section 5.12, we examine the robustness of our forecasting results for eight different combinations of end-of-month and monthly average data and conclude our results are robust.

Whenever available (Australia, Canada, Germany, Switzerland, UK and US), we use constant maturity zero coupon yields, and when unavailable we use yield to maturity. Using the spot rate and home and foreign interest rates, we calculate theoretical forward rates on the basis of covered interest rate parity as defined in equation (10). All data is available in real time and not revised. Our data sources are detailed in the appendices.

\subsection{The one-period regression}

\footnotetext{
${ }^{9}$ Trading turnover data of the Chinese renminbi/US dollar rate is available since 2010, when it accounted for $0.8 \%$ of global foreign exchange market turnover. This share has increased to $4.1 \%$ by 2019 . We do not include the renminbi in our analysis, because it is not a fully convertible and freely floating currency and some assumptions of the underlying monetary model are unlikely to be valid. Moreover, long-maturity interest rates are available from the Bank of China website starting in March 2006 only.
} 
The one-period regression, equation (1) with $k=1$ or equations (11) and (12), is important for forecasting, as Berkowitz and Giorgianni (2001) demonstrate.

$* * *$ Table $2 * * *$

The in-sample one-period slope coefficients from our model are significantly negative when using long-maturity forward rates, as shown in Block 2-4, Panel 1, Table 2. In contrast, when using the one-month maturity forward rate (Block 1, Table 2), slope coefficients tend to be insignificant and smaller in absolute terms, while regressions have lower $\mathrm{R}^{2}$. Beyond using monthly data, we also estimated one-period regressions using non-overlapping annual data (see Table A2 in the appendices). The $\mathrm{R}^{2}$ associated with annual data for the panel model is 0.15 when using the 10-year forward rate, a rather high value given the spot exchange rate of floating currencies is typically approximated as a random walk. $\mathrm{R}^{2}$ are relatively high for all currency pairs except the CHF/DEM rate, with the highest values obtained for the GBP/USD rate (0.32), SEK/USD rate (0.25) and the DEM(EUR)/USD rate $(0.20)$.

\subsection{Robust confidence interval for the regression parameter}

Theoretical long maturity forward rates are rather persistent time series and might even contain a unit root. The issue of persistent or non-stationary predictors is hardly considered in the exchange-rate forecasting literature ${ }^{10}$. For example, this issue is not even mentioned in the literature survey of Rossi (2013) or in the comparative analysis of Cheung et al (2019). We have downloaded the data on predictors used by Cheung et al (2019) and found that the null hypothesis of unit root cannot be rejected for almost $40 \%$ the predictors used in their study ${ }^{11}$.

\footnotetext{
${ }^{10}$ A rare example of testing the time-series properties of the predictor is Engel et al (2007). They could not reject the null hypothesis of no cointegration for one of their three models, implying the error correction term in their forecasting model is non-stationary. However, they still found this unbalanced regression provided superior outof-sample forecasts.

${ }^{11}$ Cheung et al (2019) used eight models of which we could replicate the dataset for six. They considered four US
} 
In our dataset, we found that long maturity theoretical forward rates are stationary for four currency pairs (the US dollar against the German mark, British pound sterling and Canadian dollar, and the rate of the German mark against the British pound sterling), but not for the other six currency pairs ${ }^{12}$

We therefore used the method proposed by Rossi (2007) to calculate confidence intervals of regression parameter of the one-period regression, which method is robust whether the regressor has a unit root or not. Table 3 shows that when the 1-month forward rate is used as the regressor, zero is always within the 95 percent confidence interval. When the 10 -year forward rate is used as the regressor, for five of the twelve currency-pairs, zero is not within the confidence interval and for the remaining seven cases, most of the confidence interval range is negative. We therefore conclude that even though theoretical long-maturity forward rates are rather persistent and might even contain a unit root, they can be useful in exchange rate forecasting.

$* * *$ Table $3 * * *$

\section{Out-of-sample forecasting}

\subsection{Forecast evaluation sample}

We use the 1979-1989 sample period (or mid-1980s to 1989 when earlier data is not available) to form an initial estimate and evaluate our out-of-sample forecasts for the January 1990 February 2020 period using forecasting horizons between 1 month and 5 years. We use a recursive estimation scheme ${ }^{13}$ in our baseline forecasting exercise, but as a robustness check

\footnotetext{
dollar currency pairs (CAD, JPY, CHF and GBP) in their full sample estimations. Of these $6 \times 4=24$ cases, we could reject the null hypothesis of unit root (for those predictors for which estimation is not needed) or the null hypothesis of no cointegration (for those models which are based on the estimation of a cointegration relationship) for 15 cases and we could not reject these null hypotheses for 9 cases.

${ }^{12}$ Darvas and Schepp (2009) were the first to notice that some long-maturity theoretical forward exchange rates of major currencies are stationary.

${ }^{13}$ We first estimate the models for 1979M1-1989M12 and calculate out-of-sample forecasts for 1990M1-
} 
also use a rolling estimation scheme with windows of various lengths.

\subsection{Statistics}

Rossi (2013) highlighted that "The toughest benchmark is the random walk without drift" (p. 1063), which we use as the benchmark for our models. We use four out-of-sample forecasting evaluation criteria.

The first indicator, which is the most widely used in the literature, is the mean squared forecast error (MSFE) relative to the driftless random walk $\left(M S F E R_{k}\right)$ :

$$
\operatorname{MSFER}_{k}=100 \cdot \frac{P^{-1} \sum\left(s_{t+k}-\hat{s}_{M, t, t+k}\right)^{2}}{P^{-1} \sum\left(s_{t+k}-\hat{s}_{R W, t, t+k}\right)^{2}}
$$

where $k$ is the forecast horizon, $s_{t+k}$ is the log exchange rate at period $t+k, \hat{s}_{M, t, t+k}$ is the $\log$ of the forecast made at time $t$ for $t+k$ by our model, $\hat{s}_{R W, t, t+k}$ is the log of the random walk forecast made at time $t$ for $t+k$, and $P$ is the number of forecasts made. Therefore, this measure is calculated as a percentage where a value below 100 indicates that our model outperforms the driftless random walk.

The driftless random walk benchmark is nested in all models. When comparing nested models, standard asymptotic tests do not apply when testing the null hypothesis of equal forecast accuracy. Clark and West $(2006,2007)$ showed that under the null hypothesis that the data generating process is the random walk (or any parsimonious model), estimation of parameters of a larger model introduces noise into the forecasting process that will, in finite samples, inflate its MSFE. Clark and West (2006, 2007) also suggested an adjustment of mean squared prediction error statistics, which leads to approximately normal tests. Clark and West (2006, 2007) derived their results for models estimated in direct form, i.e. in the form of long-horizon regressions, and when the forecasts are evaluated using a rolling-window estimation technique.

1994M12. Next, we estimate the models for 1979M1-1990M1 and calculate out-of-sample forecasts for 1990M21995M1, and so on. 
They also found that a bootstrap test has favorable properties in terms of both size and power. However, Pincheira and West (2016) found that the Clark and West $(2006,2007)$ statistics also worked reasonably well when the iterated method is used to obtain multi-step forecasts and the recursive estimation scheme is used. For the iterated method they considered a simple first order autoregression for the predictor, in the same way as in our forecasting model (13).

We therefore use two methods to test the null hypothesis of equal MSFE of our model and the random walk against the one-sided alternative that our model is better: (1) a non-parametric bootstrap test similar to those used in related papers such as Mark (1995), Kilian (1999) and McCracken and Sapp (2005), and (2) the Clark and West (2006, 2007) statistics. Since we find that the two methods lead to rather similar results (which we demonstrate for the detailed DEM/USD forecasting results), while calculating bootstrapped p-values is rather time consuming, but the calculation of the Clark and West statistics is instantaneous, in most of this paper we derive the p-values from the Clark and West statistics. For this statistic, we estimate the long-run variance using the method of Newey and West (1987).

The second indicator is the share of correct sign (i.e. direction of change) predictions relative to the spot exchange rate $\left(D O C S_{k}\right)$ :

$$
\operatorname{DOCS}_{k}=100 \cdot P^{-1} \sum I\left(s_{t+k}-s_{t}, \hat{s}_{M, t, t+k}-s_{t}\right),
$$

where the $I(.,$.$) is an indicator function having the value 1$ if its two arguments have the same sign and zero otherwise. Therefore, this measure is calculated as a percentage where a value above 50 indicates our model predicts the direction of change well more than half of the time. We use the test developed by Pesaran and Timmermann (1992) to test the null hypothesis that our model has no power in predicting the exchange rate. We use the same test for testing the null hypothesis that the forward exchange rate has no power in predicting the exchange rate. The third indicator is the share of correct sign (i.e. direction of change) predictions relative to the forward exchange rate $\left(D O C F_{k}\right)$ : 


$$
\operatorname{DOCF}_{k}=100 \cdot P^{-1} \sum I\left(s_{t+k}-f_{t}, \hat{s}_{M, t, t+k}-f_{t}\right) .
$$

From a currency trading perspective, the share of correct sign predictions relative to the forward exchange rate is more relevant than predicting the direction of change relative to the spot exchange rate, because a forward transaction is settled at the forward rate. The deviation of the future spot rate from the forward rate (and not from the current spot rate) determines whether there is a profit or loss. We are not aware of papers calculating the share of correct sign predictions relative to the forward exchange rate. We again use the test of Pesaran and Timmermann (1992).

The fourth indicator is the excess return on a trading strategy based on our forecasting model where a positive value indicates excess profit. For comparison, we also report the return on a simple carry trade investment strategy.

The carry trade strategy on currency markets postulates that the currency with the higher interest rate is purchased by borrowing in a currency which has a lower interest rate. An equivalent carry trade transaction can be conducted in forward or futures markets, by buying a high-yield currency forward against a low-yield currency. The excess return, ignoring transaction costs and leverage, to the simple carry trade strategy is:

$$
r_{C T, t+k}^{(k)}= \begin{cases}d_{t}^{(k)}-s_{t+k} & \text { if } d_{t}^{(k)}>s_{t} \\ 0 & \text { if } d_{t}^{(k)}=s_{t} \\ s_{t+k}-d_{t}^{(k)} & \text { if } d_{t}^{(k)}<s_{t}\end{cases}
$$

where $r_{C T, t+k}^{(k)}$ is the excess return of the carry trade strategy realized in time $t+k$ for a forward transaction opened in time $t$ for $k$-period ahead. For example, consider the New Zealand dollar/USD dollar pair over one period. When the New Zealand interest rate is higher than the US interest rate $\left(d_{t}^{(1)}>s_{t}\right)$, the New Zealand dollar is purchased against the US dollar and the return in the next period is $d_{t}^{(1)}-s_{t+1}$. That is, if the New Zealand dollar appreciates $\left(s_{t+1}<\right.$ $\left.s_{t}\right)$, remains unchanged $\left(s_{t+1}=s_{t}\right)$, or depreciates less than the forward premium $\left(s_{t+1}<\right.$ 
$\left.d_{t}^{(1)}\right)$, a profit is realized. This return is in excess of the risk-free rate. To enter a forward or futures transaction, the investor must post a margin in the form of cash or appropriate highquality marketable securities, such as a government bond. The investor earns interest income from the collateral. Therefore, the payoff for the forward transaction can be regarded as return in excess of the risk-free interest rate, such as a government bond yield. Forward currency market transactions typically involve use of leverage, as only a small percentage of the notional amount of the transaction (for example 4\%) is required by the financial intermediator as collateral. However, in our return calculations, we do not consider levered positions or transition $\operatorname{costs}^{14}$.

The trading strategy return implied by our forecasting model is defined as follows:

$$
r_{M, t+k}^{(k)}= \begin{cases}d_{t}^{(k)}-s_{t+k} & \text { if } d_{t}^{(k)}>s_{t+k \mid t} \\ 0 & \text { if } d_{t}^{(k)}=s_{t+k \mid t} \\ s_{t+k}-d_{t}^{(k)} & \text { if } d_{t}^{(k)}<s_{t+k \mid t}\end{cases}
$$

where $r_{M, t+k}^{(k)}$ is the excess return of an investment strategy based on our model and $s_{t+k \mid t}$ is the forecast in period $t$ for period $t+k$. Continuing the example above, if our forecast suggests the New Zealand dollar will appreciate $\left(s_{t+1 \mid t}<s_{t}\right)$, will remain unchanged $\left(s_{t+1 \mid t}=s_{t}\right)$, or will depreciate less than implied by the forward rate $\left(s_{t+1 \mid t}<d_{t}^{(1)}\right)$, the New Zealand dollar is purchased against the US dollar and the return for period $t+1$ is $d_{t}^{(1)}-s_{t+1}$.

We report the mean annualized profit over our out-of-sample evaluation period. We test whether the mean annualized profit based on our model is larger than zero and whether it is larger than the profit of carry trade. We test these hypotheses by $t$-tests based on the Sharpe ratio (profit divided by its standard deviation), for which we estimate the long-run variance using the method of Newey and West (1987).

\footnotetext{
${ }^{14}$ See Darvas (2009) for the quantification of transaction costs and the impact of leverage on carry trade returns.
} 


\subsection{Baseline results for the German mark / US dollar rate}

*** Table $4 * * *$

Table 4 shows baseline results for the USD/DEM exchange rate. Our full-sample results indicate better-than-random walk forecasts for both short and long forecasting horizons, using three alternative maturity forward rates and four forecast evaluation criteria (Table 4). The point estimates of the mean squared forecast error (MSFE) of our models are lower than that of the driftless random walk for forecasting horizons between 1 month and 5 years and for all alternative models using different maturity forward rates, with the sole exception of the model using the 10-year maturity forward rate for 3-month forecasting horizon. In this case the point estimate is also statistically less than $100 \%$ at the 11 percent significance level according to our bootstrap test and at 2 percent significance level according to the Clark and West $(2006,2007)$ test. For all models, longer forecasting horizons are associated with stronger results relative to the driftless random walk. Table 4 also presents results from forecasts using the simple equallyweighted combination of the three models with alternative-maturity forward rates. Our findings corroborate findings from forecast combination literature (see e.g. Timmermann, 2006) showing a simple equal-weight combination performs well. Interestingly, the combined forecast outperforms the best individual model for six of eight alternative forecast horizons reported based on MSFE statistics. The improvement in forecast accuracy as measured by the MSFE of the combined model over the driftless random walk is about $10 \%$ for 1 -year ahead forecasts, $30 \%$ for 3-year ahead forecasts, and about $40 \%$ for 5 -year ahead forecasts. These are rather large improvements relative to models presented in past works. For example, Rossi (2013) analyzed the predictive ability of six single equation and two multiple-equation models for different sample periods staring between the 1960s and 1990s and ending in mid-2011 and finds the bulk of the MSFE ratios are over 1 (or 100 if expressed it in percent) for both short-horizon 
(1 month or 1 quarter) and long horizon (4 years) forecasts. Among the 111 ratios reported for the 4-year forecasting horizon, only two were lower than 1 , and both by only 1 percent.

The two alternative ways for testing the null hypothesis that the MSFE of our model is the same as that of the random walk led to rather similar results, in line with the findings of Pincheira and West (2016). The exceptions are few and do not change the big picture.

In contrast to the excellent forecasts of our model, the forward rate itself as a prediction never led to smaller forecast errors than the random walk in our full out-of-sample evaluation period. $* * *$ Figure $1 * * *$

The first panel of Figure 1 shows actual exchange rate movements (solid blue line) and out-ofsample forecasts five years ahead (light red lines) using the combined model for the DEM/USD rate. For better readability of the panels, forecasts made only in March, June, September and December of each year are shown. The figure indicates that our model was capable of indicating both upward and downward turning points rather well, although many of the large excessive swings were forecasted to turn around earlier.

Turning to direction of change predictions, our models predict the correct signs in more than half of the cases for all three alternative models, as well as their combination, and for all forecasting horizons between one month and five years. At the one-month horizon correct sign predictions relative to the spot rate were made in about 52-53 percent of cases, while at the fiveyear horizon in about 70 percent of cases, which is really large. The bulk of these sign predictions are statistically significant. In contrast, the forward rate itself predicts the direction of change in less than 50 percent of cases for all forecast horizons in our full out-of-sample evaluation period.

Correct sign prediction relative to the forward rate is even more impressive, with $75 \%-78 \%$ correct predictions at 3-5-year horizons by the combined model.

It is therefore not surprising that a trading strategy based on our model leads to profit. The 
annualized excess return amounts to about 3 percent per year, which is economically significant, given that the average annualized US dollar interest rate was 3.1\% for the one-month interbank rate and $4.5 \%$ for the 10-year government bond yield from 1990-2020. The annualized excess returns are significantly larger than zero, though generally not significantly larger than the return based on carry trade on shorter forecasting horizons, but significantly larger on longer forecasting horizons.

*** Figure $2 * * *$

By assuming an initial investment value of 100, Figure 2 visualizes the trading profit by considering one-month and three-year reinvestment decisions. That is, in the former case the cumulative value of investment is reinvested according to our one-month ahead forecast for one-month horizon, while for the latter case the investment decision is made in every third year based on our three-year ahead forecasts. The same exercise is made for the carry trade too. For the DEM/USD currency pair, the one-month reinvestment horizon led to rather similar total cumulative returns for our model and the carry trade in 1990-2020, though return volatility is lower in the case of our model than for carry trade returns. For the three-year reinvestment horizon, eight of the ten decisions were the same for our model and for the carry trade. It is therefore not surprising that the overall performance over the 30 -year period is rather similar for our model and the carry trade, even though our model led to much lower MSFE than the random walk ${ }^{15}$. This finding suggests that better forecasting ability of a model than the random walk might not be associated with significantly better model-based return than the return on carry trade.

\footnotetext{
${ }^{15}$ Note that the 3-year trading simulation reported on Figure 2 is a particular non-overlapping result, showing the cumulative value of an initial investment of 100 made in December 1989. The average annualised 3-year return results reported in Table 4 considers investments made in each month in December 1989 - December 1992, which average is significantly larger in the case of our models than the carry trade returns.
} 


\subsection{Other currencies}

Because of space constraints and the large number of robustness tests performed, for other currency pairs, we report only the MSFE results based on the combined model. Detailed results for individual models and for all four forecast evaluation criteria are available in the appendices.

\section{$* * *$ Table $5 * * *$}

Our model also performs well for the bulk of the other currency pairs. In particular, both shortand long-horizon forecasts beat the driftless random walk for the US dollar rate relative to the British pound sterling, Norwegian krone, Swedish krona, Australian dollar. The same applies for the Japanese yen when the estimation starts in 1985. Results are also strong for the rate of the German mark relative to the British pound sterling.

For the Canadian dollar-US dollar, New Zealand dollar-US dollar and Japanese yen-German mark/euro pairs, short-term forecasting results are less favorable, while long-term forecasting results beat the random walk. Further research should explore if these somewhat weaker results relate to deviations from the underlying assumptions of the monetary model of exchange rate that we used to derive our forecasting model.

In the case of the Swiss franc/US dollar rate, full sample MSFE statistics are larger than that of the random walk in the baseline specification. However, poor forecasting results over the full sample period are not surprising. As the euro-area crisis escalated after 2010, Switzerland received increasing capital inflows. In September 2011 the Swiss National Bank unexpectedly introduced a floor for the euro/Swiss franc rate at 1.2 to limit currency appreciation. This floor meant effectively fixing the value of the Swiss franc to the euro and remained in place until January 2015. In the sub-sample sensitivity analysis below, we show forecasting results for the Swiss franc/US dollar rate were very strong in the out-of-sample evaluation period from 1990 to 2006. The finding for the rate between the Swiss franc and German mark/euro are similar 
and in fact more favorable, since our baseline forecast beats the random walk in our first three sub-periods covering 1990-2010, and the full-sample forecasts are also statistically better than the random walk for forecasting horizons between 1 and 5 years, even if the point estimates are larger than 100. Panel models work even better for the Swiss franc, against both the dollar and the mark/euro.

\subsection{Sub-sample sensitivity}

The last four columns of Table 4 and Table 5 show out-of-sample forecasting results for 3-year ahead predictions using alternative sample periods. For almost all currency pairs, our forecasts beat the random walk in 1993-1999, 2000-2006 and 2011-2020 sub-periods, but not the 20072010 period, which included the global financial and economic crisis. US dollar exchange rate movements during the period were erratic, making forecasting difficult for all models. Interestingly, our model continues to forecast well in the 2007-2010 period for four currency pairs: British pound sterling relative to the US dollar, British pound sterling relative to the German mark/euro, Japanese yen relative to the German mark/euro, and the Swiss franc relative to the German mark/euro.

Table 4 also indicates stunning sign prediction forecasts in sub-periods which do not include the period of the global financial crisis. For example, the combined model for the German mark/euro rate against the US dollar predicted the deviation from the 3-year forward rate correctly in $94 \%$ of the cases in 1993-1999 and $97.6 \%$ of the cases in $2000-2006$. The $74.5 \%$ correct prediction share in 2011-2020 is also impressive. It is therefore not surprising the modelbased trading strategy led to rather high excess returns, amounting to $4.9 \%$ per year in 1993 1999 and $7.8 \%$ per year in 2000-2006. 


\subsection{Dropping 1979-84 data}

In our analysis thus far, we have used the 1979-1989 sample period, with a few data driven exceptions, to form an initial estimate and evaluated our forecasts in the 1990-2020 period. The US dollar experienced large price fluctuations in 1980-1984. As a robustness test, we shorten the estimation sample period to start in January 1985, but continue to evaluate the out-of-sample forecasts in 1990-2020.

Table 5 Panel B shows that for most currencies, forecasting results are slightly weaker in this case, though they still beat the random walk by a large margin. Exceptions were the Australian dollar, for which short-term forecast are slightly worse, while long-term forecasts are slightly better than our baseline, and the Japanese yen, for which results are much stronger when the sample starts in $1985^{16}$. The explanation for more favorable Japanese results could be the strong nominal and real appreciation during the 1979-1984 period, while the monetary model assumes purchasing power parity holds in the long run.

Our generally favorable results for the longer sample period may be related to the ability of our model to capture adjustments to the equilibrium value of the exchange rate, which can be better estimated using longer sample periods.

\subsection{Panel estimation}

Our forecasting exercise thus far has been simple in being based on the analysis of single currency pairs and involving the estimation of only four parameters and with OLS. As a robustness test, we perform panel estimation, where we force parameters $\theta_{2}$ and $\theta_{4}$ in model (13) to be common across currency pairs, but allow the intercepts, $\theta_{1}$ and $\theta_{3}$, to vary. We find panel estimation improves both short- and long-horizon forecasts in the case of eight currency

\footnotetext{
${ }^{16}$ For the New Zealand dollar and the Swiss franc, results for the sample starting in 1985 are the same as the baseline results, because the estimation starts after 1985 in the baseline too due to missing data.
} 
pairs (CHF/USD, NOK/USD, SEK/USD, CAD/USD, AUD/USD, NZD/USD, GBP/DEM, JPY/DEM). It is useful to highlight that the full-sample MSFE point estimates are below 100 at all forecasting horizons for the NZD/USD rate and these estimates are statistically significant. The full-sample results for the CHF/USD rate statistically significantly beat the random walk in all but the 3-month forecasting horizons, though sub-sample results continue to indicate weak forecasts in 2011-2020, which includes the 2011-2015 fixed exchange rate episode. Panel estimation leads to slightly better short-horizon forecasting at the cost of slightly worse long-horizon forecasts for two currency pairs (DEM/USD and GBP/USD). Panel estimations worsen forecasts considerably for the JPY/USD rate. For the CHF/DEM rate, short-run forecasts are slightly better with panel estimation, but longer-term forecasts are considerably worse. Overall, these results show our findings are robust to single equation versus panel estimation.

\subsection{Alternative model}

Thus far we have used the simple setup described in model (13). The first equation of this model is an error-correction equation, while the second equation is a simple autoregression for the error-correction term (the theoretical forward rate). An alternative is a standard vector error correction model (VECM):

$$
\begin{gathered}
s_{t+1}-s_{t}=\varphi_{1}+\varphi_{2}\left(s_{t}-s_{t-1}\right)+\varphi_{3}\left(\tilde{l}_{t}^{(h)}-\tilde{l}_{t-1}^{(h)}\right)+\varphi_{4} \cdot d_{t}^{(h)}+\varepsilon_{t+1,1}^{(1)} \\
\tilde{l}_{t+1}^{(h)}-\tilde{l}_{t}^{(h)}=\varphi_{5}+\varphi_{6}\left(s_{t}-s_{t-1}\right)+\varphi_{7}\left(\tilde{\imath}_{t}^{(h)}-\tilde{\imath}_{t-1}^{(h)}\right)+\varphi_{8} \cdot d_{t}^{(h)}+\varepsilon_{t+1,1}^{(2)},
\end{gathered}
$$

where $\varphi_{i}$ are parameters to be estimated. Model (19) shares the advantageous features of model (13), since it is not estimated in overlapping samples. The model is not subject to the various information losses we described earlier, and multi-step ahead out-of-sample forecasts are calculated with a dynamic iteration method also using the identity defined in equation (10). Model (19) includes eight parameters to be estimated and can easily be replicated. 
As Table 5 Panel D shows, forecasting results using this alternative model are similar to benchmark results and also beat the random walk.

\subsection{Unit root in forward rates}

From a time series analysis perspective, our models given in equations (13) and (19) correspond to a stationary long-maturity theoretical forward rate assumption. We check the sensitivity of our forecasting results by assuming that the long-maturity forward rate is non-stationary, that is, $\theta_{3}=0$ and $\theta_{4}=1$ in the forecasting model (13), implying the long-maturity forward rate remains unchanged over the forecasting horizon. This assumption influences only multi-period ahead forecasts, but not the 1-month ahead forecasts, because the second equation in model (13) is not used for that.

Forecasting results, presented in Table 5 Panel E, are weaker in this case. For example, in the DEM/USD case at the 5-year ahead forecast horizon, the MSFE ratio is 57.0 in our baseline case, but 82.8 in the unit root case. For the GBP/USD rate at the 5-year ahead forecast horizon the baseline result is 71.1 , and 126.4 , assuming unit root. Altogether, the unit root assumption worsens forecasting results for eight of our twelve currency pairs, while for the remaining four currency pairs (NOK/USD, AUD/USD, GBP/DEM, JPY/DEM) short-horizon forecasts are almost identical and long-horizon forecasts are slightly better under the unit root assumption.

\subsection{VAR in levels}

A vector autoregression model (VAR) in levels can be consistently estimated irrespective of whether the variables have a unit root or not. We therefore employ a simple $\operatorname{VAR}(1)$ as a robustness check: 


$$
\left[\begin{array}{l}
S_{t+1} \\
d_{t+1}^{(h)}
\end{array}\right]=\left[\begin{array}{ll}
\omega_{1,1} & \omega_{1,2} \\
\omega_{2,1} & \omega_{2,2}
\end{array}\right]\left[\begin{array}{c}
s_{t} \\
d_{t}^{(h)}
\end{array}\right]+\left[\begin{array}{c}
\varepsilon_{t+1,1}^{(1)} \\
\varepsilon_{t+1,1}^{(2)}
\end{array}\right]
$$

where $\omega_{i, j}$ are parameters to be estimated.

Table 5 Panel F shows VAR forecasts are generally inferior to our baseline results. For example, the one-month ahead MSFE ratio in the case of DEM/USD is 99.2 in our baseline results, but 103.3 for the VAR specification. For the 5-year forecasting horizon, our baseline result is 57.0, compared to 62.1. Our baseline results are consistently stronger than VAR results for all forecasting horizons for the DEM/USD, CHF/USD, AUD/USD GBP/DEM, and CHF/DEM rates, for all but one forecasting horizon for the JPY/DEM rate, and for all but two forecasting horizon for the JPY/USD, NOK/USD, CAD/USD rates. Therefore, for these nine currency pairs our baseline model is preferable to the VAR.

In the case of the GBP/USD rate, short-horizon forecasts (up to one year) are much better in our baseline than in the VAR case, yet for longer horizon forecasts the VAR model outperforms the baseline specification. For the SEK/USD rate, short- and long-horizon forecasts are better in our baseline than in the VAR case, but in between the VAR performs significantly better. The VAR model has a clear advantage in the case of the NZD/USD rate. While for forecasting horizons up to one year, baseline results are better than VAR results, at longer horizons the VAR model is clearly better. For example, for the 5-year forecasting horizon, the baseline model led to a 98.4 MSFE ratio, while the ratio from the VAR model was 66.4.

\subsection{Recursive versus rolling estimation}

Up to this point, we have used recursive estimation for our forecasts. The first observation of the estimation sample was January 1979 for most currencies and mid-1980s for those with missing early data. We extended the last observation of the estimation sample by one period for each forecast round. We test the robustness of our findings to rolling estimation samples with 
varying lengths between 60 and 240 months. We find that our results are robust to recursive versus rolling estimation techniques, provided the length of the rolling window is sufficiently long to capture long-run tendencies.

$* * *$ Table $6 * * *$

Table 6 (for the DEM/USD rates) and Table A4 in the appendices (for all other currency pairs) show forecasting results are weak when relatively short rolling windows are used for estimation, and are conversely stronger for relatively longer rolling windows. In the case of the DEM/USD rate, the 220- and 240-month rolling window estimations led to somewhat better results for all forecasting horizons than our benchmark results based on the recursive estimation technique, while the 200-month rolling window is slightly better than the recursive estimation for longer (but not shorter) forecast horizons. The recursive estimation technique is better than any rollingwindow estimation considered for the US dollar rates relative to GBP, CAD, NOK and SEK as well as the GBP/DEM rate (with the sole exception of the 5-year ahead forecast for the 240month rolling window). For the CHF/USD, CHF/DEM, JPY/DEM the 220-month rolling window results are slightly better than our baseline results, while for the NZD/USD the rate the 200-month window looks the best. Relatively short rolling windows work well only in the cases of the AUD/USD (60 and 80-month windows for 2-5-year ahead forecasts, but short-term forecasts in this case are worse than the random walk) and JPY/USD (120-month rolling window is the best) rates.

Overall, for ten of the twelve currency pairs we study, either the recursive estimation technique works the best, or relatively long rolling windows. The improved forecast accuracy for longer rolling estimation windows likely indicates our model incorporates longer-run tendencies in the form of an error-correction relationship, which can better be captured over longer periods. While for some currency pairs, specific long rolling estimation samples lead to better forecasting results than our benchmark recursive estimation results, finding 'optimal' lengths 
for rolling window estimation is not our aim.

\subsection{Combining end-of-month and monthly average data}

$* * *$ Table $7 * * *$

In several cases, long-maturity theoretical forward rates are calculated using end-of-month spot exchange rates and monthly average interest rates, because of the lack of availability of end-of-month interest rate data. This inconsistency could have implications for our forecasting results. To test for this impact, we perform a robustness check for the GBP/USD pair, the only currency pair for which daily interest rate data is available for the entire sample period. We report forecasting results using eight different methodologies to construct the data:

1. All data end-of period (baseline results in Table 5).

2. Exchange rate end of period, interest rates period average.

3. Exchange rate and US interest rate end of period, UK interest rates period average.

4. Exchange rate and UK interest rate end of period, US interest rates period average.

5. Exchange rate period average, interest rates end of period.

6. Exchange rate and US interest rate period average, UK interest rates end of period.

7. Exchange rate and UK interest rate period average, US interest rates end of period.

8. All data period average.

Results are robust to these alterations. This is not surprising as our model captures long-term developments. Alternate data construction methods lead to relatively small alterations, and do not influence long-run trends.

\section{Summary}

This paper presents a new model based on a novel combination of the general class of theoretical exchange rate models analyzed by Engel and West (2005) and the error-correction forecasting 
equation of Mark (1995). We show, using the example of the general form of money-income models, that the gap between the fundamental equilibrium exchange rate and the actual exchange rate can be approximated with the long-maturity theoretical forward exchange rates. Using four out-of-sample forecast evaluation criteria, we find the model forecasts significantly outperform the driftless random walk for both short and long-horizon forecasting for most of nine US dollar exchange rate series (German mark/euro, British pound sterling, Japanese yen, Swiss franc, Canadian dollar, Australian dollar, New Zealand dollar, Norwegian krone, Swedish krona), as three additional German mark/euro rates, the British pound sterling, Japanese yen and the Swiss franc. The forecast accuracy of our models improves with the forecast horizon and is economically significant for most of the exchange rates. For example, in the case of the most heavily traded German mark (euro) rate against the US dollar, our outof-sample forecast beats the driftless random walk by $0.8 \%$ at one-month horizon, $11.2 \%$ at one-year horizon, $32.5 \%$ at three-year horizon and $43.0 \%$ at five-year horizon, using the mean forecast error statistics in the 1990-2020 out-of-sample evaluation period. Our model leads to impressive direction of change forecasting results, relative to both the spot exchange rate and the forward exchange rate, while a trading simulation based on our model forecasts leads to economically large excess returns.

Our results are statistically significant and robust to alternate sample periods, single currency pairs or panel estimation, specification of the error correction model, recursive versus rolling sample estimation, and various data-construction methodologies. Forecasting results are better when the long maturity theoretical forward exchange rate is assumed to be stationary than when it is not. These forecasting results exhibit a marked improvement over past works. Further research should explore the role of the underlying assumptions of the monetary model of exchange rate in our forecasting results, since we use the monetary model to derive our forecasting equation. Such research should explore if our results can be extended to the 
currencies of emerging and developing countries.

Our forecasting results suggest a close relationship between the expected components of longterm yields and the expected path of the exchange rate, with implications for exchange rate theories. Further research should develop theoretical models incorporating this relationship.

\section{Acknowledgements}

We are thankful for comments and suggestions to earlier Journal of International Economics Editor Charles Engel, two anonymous reviewers, Philippe Bacchetta, Menzie D. Chinn, Todd E. Clark, Andrew Fodor, James D. Hamilton, Henk Jager, Franc Klaassen, Zalán Kocsis, Gábor Körösi, Gábor Rappai, Andrew K. Rose, Pierre L. Siklos, András Simon, Mark P. Taylor, Timo Teräsvirta, Casper de Vries, Ákos Valentinyi and conference and seminar participants at the 11th International Conference on Macroeconomic Analysis and International Finance (Rethymno, 2007), Central Bank of Hungary (Budapest, 2007), the 5th INFINITI Conference on International Finance (Dublin, 2007), Corvinus University of Budapest (2007), University of Pécs (2007 and twice in 2014), Royal Economic Society Annual Conference (Warwick, 2008), Tinbergen Institute Rotterdam (2008), the Bank for International Settlements (Basel, 2008), ECOMOD (Berlin, 2008), NAKE Research Day (Utrecht, 2008), Hungarian Society of Economics (Budapest, 2008 and 2017), the 24th Annual Congress of the European Economic Association (Barcelona, 2009), the 44th Annual Conference of the Canadian Economic Association (Quebec City, 2010), the 34th International Symposium on Forecasting (Rotterdam, 2014), the 12th INFINITI Conference on International Finance (Prato, 2014), the 5th World Finance Conference (Venice, 2014), and the 6th Annual Conference of the International Association for Applied Econometrics (Nicosia, 2019). Thanks go to Kristóf Németh and Balázs Varga for running the test of Rossi (2007). Financial support from OTKA Grant No. K 61221 and the National Excellence in 
Higher Education Program in Hungary (contract number 20765-3/2018/FEKUTSTRAT) is gratefully acknowledged. Zsolt Darvas was affiliated with Argenta ZRt when part of this research was conducted.

\section{References}

Altavilla, C., De Grauwe, P., 2010. Forecasting and Combining Competing Models of Exchange Rate Determination. Applied Economics 42, 3455-3480.

Bank for International Settlements, 1993, 1996, 1999, 2002, 2005, 2008, 2011, 2014, 2017, and 2020. Triennial Central Bank Survey - Foreign Exchange and Derivatives Market Activity in [the preceding year of publication]. Basel: BIS.

Ball, L., 2001. Another Look at Long-Run Money Demand. Journal of Monetary Economics 47. 31-44.

Berge, T.J., 2014. Forecasting Disconnected Exchange Rates. Journal of Applied Econometrics 29, 713-735.

Berkowitz, J., Giorgianni, L., 2001. Long-Horizon Exchange Rate Predictability? The Review of Economics and Statistics 83, 81-91.

Bilson, J.F.O., 1978. The Monetary Approach to the Exchange Rate: Some Empirical Evidence. IMF Staff Papers 25, 48-75.

Brooks, C., Burke, S.P., Stanescu, S., 2016. Finite Sample Weighting of Recursive Forecast Errors. International Journal of Forecasting 32, 458-474.

Ca'Zorzi, M., Kolasa, M., Ribaszek, M., 2017. Exchange rate forecasting with DSGE models. Journal of International Economics 107, 127-146.

Cerra. V., Saxena, S.C., 2010. The Monetary Model Strikes Back: Evidence from the World. Journal of International Economics 81, 184-196. 
Cheung, Y.W., Chinn, M.D., Pascual, A.G., Zhang, Y. 2019. Exchange rate prediction redux: New models, new data, new currencies. Journal of International Money and Finance 95, $332-362$.

Chinn, M.D. Quayyum, S. 2012. Long Horizon Uncovered Interest Parity Re-Assessed. NBER Working Paper No. 18482

Chinn, M.D., Meredith, G., 2005. Testing Uncovered Interest Rate Parity at Short and Long Horizons during the Post-Bretton Woods Era. NBER Working Paper no. 11077.

Chinn, M.D., Moore, M.J., 2011. Order Flow and the Monetary Model of Exchange Rates: Evidence from a Novel Data Set. Journal of Money, Credit, and Banking 43, 1599-1624.

Clarida, R.H., Taylor, M.P., 1997. The Term Structure of Forward Exchange Rate Premiums and the Forecastability of Spot Exchange Rates: Correcting the Errors. The Review of Economics and Statistics 79, 353-361.

Clark, T.E., West, K.D., 2006. Using Out-of-Sample Mean Squared Prediction Errors to Test the Martingale Difference Hypothesis. Journal of Econometrics 135, 155-186.

Clark, T.E., West, K.D., 2007. Approximately Normal Tests for Equal Predictive Accuracy in Nested Models. Journal of Econometrics 138, 291-311.

Dal Bianco, M., Camacho, M., Perez Quiros, G., 2012. Short-Run Forecasting of the EuroDollar Exchange Rate with Economic Fundamentals. Journal of International Money and Finance 31, 377-396.

Darvas, Z., 2008. Estimation Bias and Inference in Overlapping Autoregressions: Implications for the Target Zone Literature. Oxford Bulletin of Economics and Statistics 70(1), 1-22.

Darvas, Z., 2009. Leveraged Carry Trade Portfolios. Journal of Banking and Finance, 33(5), 944-957.

Darvas, Z., Schepp, Z., 2007. Forecasting exchange rates with long maturity forward rates. Working Paper 2007/5, Department of Mathematical Economics and Economic Analysis, 
Corvinus University of Budapest, available at:

https://ideas.repec.org/p/mkg/wpaper/0705.html

Darvas, Z., Schepp, Z., 2009. Long Maturity Forward Rates of Major Currencies are

Stationary. Applied Economics Letters 16(11), 1175-1181.

Della Corte, P., Sarno, L., Tsiakas, I., 2009. An Economic Evaluation of Empirical Exchange

Rate Models. Review of Financial Studies 22, 3491-3530.

Engel, C., 2014. Exchange Rates and Interest Parity, in Gopinath, G., and Helpman, E. (eds), Handbook of International Economics vol. IV, pp. 453-522, Amsterdam: North Holland.

Engel, C., Mark, N.C., West, K.D., 2007. Exchange Rate Models Are Not as Bad as You

Think, NBER Macroeconomics Annual 2007, 381-441.

Engel, C., Mark, N.C., West, K.D., 2015. Factor Model Forecast of Exchange Rates.

Econometric Reviews 34, 32-55.

Engel, C., West, K.D., 2005. Exchange Rates and Fundamentals. Journal of Political Economy 113, 485-517.

Faust, J., Rogers, J.H., Wright, J.H., 2003. Exchange Rate Forecasting: The Errors We've Really Made. Journal of International Economics 60, 35-59.

Frankel, J.A., 1979. On the Mark: A Theory of Floating Exchange Rates Based on Real Interest Differentials. The American Economic Review 69, 610-22.

Gourichas, P.O., Rey, H., 2007. International Financial Adjustment. Journal of Political Economy 115, 665-713.

Ince, O., Molodtsova, T., Papell, D.H., 2016. Taylor Rule Deviations and Out-of-Sample Exchange Rate Predictability. Journal of International Money and Finance 69, 22-44. Ireland, P.N., 2009. On the Welfare Cost of Inflation and the Recent Behavior of Money Demand. The American Economic Review 99, 1040-1052. 
Jawadi, F., Sousa, R.M., 2013. Money demand in the euro area, the US and the UK:

Assessing the role of nonlinearity. Economic Modelling 32, 507-515.

Kilian, L., 1999. Exchange Rates and Monetary Fundamentals: What do We Learn from Long-Horizon Regressions? Journal of Applied Econometrics 14, 491-510.

Kilian, L., Taylor, M.P., 2003. Why is it so Difficult to Beat the Random Walk Forecasts of Exchange Rates? Journal of International Economics 60, 85-107.

Kouwenberg, R., Markiewicz, A., Verhoeks, R., Zwinkels, R.C.J. 2017. Model Uncertainty and Exchange Rate Forecasting. Journal of Financial and Quantitative Analysis 52, 341363.

Li, J., Tsiakas, I., Wang, W., 2015. Predicting Exchange Rates Out of Sample: Can Economic Fundamentals Beat the Random Walk? Journal of Financial Econometrics 13, 293-341.

Mark, N.C., 1995. Exchange Rates and Fundamentals: Evidence on Long-Horizon Predictability. The American Economic Review 85, 201-218.

McCracken, M.W., Sapp, S.G., 2005. Evaluating the Predictability of Exchange Rates Using Long-Horizon Regressions: Mind Your p's and q's! Journal of Money, Credit and Banking 37, 473-494.

Meese, R.A., Rogoff, K., 1983. Empirical Exchange Rate Models of the Seventies: Do They Fit out of sample? Journal of International Economics 14, 3-24.

Molodtsova, T., Papell, D.H., 2009. Out-of-Sample Exchange Rate Predictability with Taylor Rule Fundamentals. Journal of International Economics 77, 167-180.

Moosa, I., 2013. Why Is It So Difficult to Outperform the Random Walk in Exchange Rate Forecasting? Applied Economics 45, 3340-3346.

Newey, W.K.,West, K.D.,1987. A simple, positive, semi-definite, heteroskedasticity and autocorrelation consistent covariance matrix. Econometrica55(3), 703-708. 
Park, C., Park, S., 2013. Exchange Rate Predictability and a Monetary Model with TimeVarying Cointegration Coefficients. Journal of International Money and Finance 37, 394410.

Pincheira, P.M., West, K.D., 2016. A comparison of some out-of-sample tests of predictability in iterated multi-step-ahead forecasts. Research in Economics 70, 304-319.

Rossi, B., 2007. Expectation Hypothesis Tests at Long Horizons. Econometrics Journal 10, $554-579$.

Rossi, B., 2013. Exchange Rate Predictability. Journal of Economic Literature 51, 1063-1119.

Samuelson, P., 1964. Theoretical Notes on Trade Problems. The Review of Economics and Statistics 46, 145-154.

Sarno, L., Taylor, M.P., 2002. The Economics of Exchange Rates. Cambridge University Press.

Sarno, L., Valente, G., 2009. Exchange Rates and Fundamentals: Footloose or Evolving Relationship? Journal of the European Economic Association 7, 786-830.

Stock, J.H., Watson, M.W., 1993. A Simple Estimator of Cointegrating Vectors in Higher Order Integrated Systems. Econometrica 61, 783-820.

Timmermann, A., 2006. Forecast combinations. In: Elliott, Granger and Timmermann (eds): Handbook of Economic Forecasting, Volume 1, 136-196.

Wang, J., Wu, J.J., 2012. The Taylor Rule and Forecast Intervals for Exchange Rates. Journal of Money, Credit, and Banking 44, 103-144.

Wright, J.H., 2008. Bayesian Model Averaging and Exchange Rate Forecasts. Journal of Econometrics 146, 329-341. 
Figure 1: Out-of-sample forecasts and actual exchange rates, 1988-2025
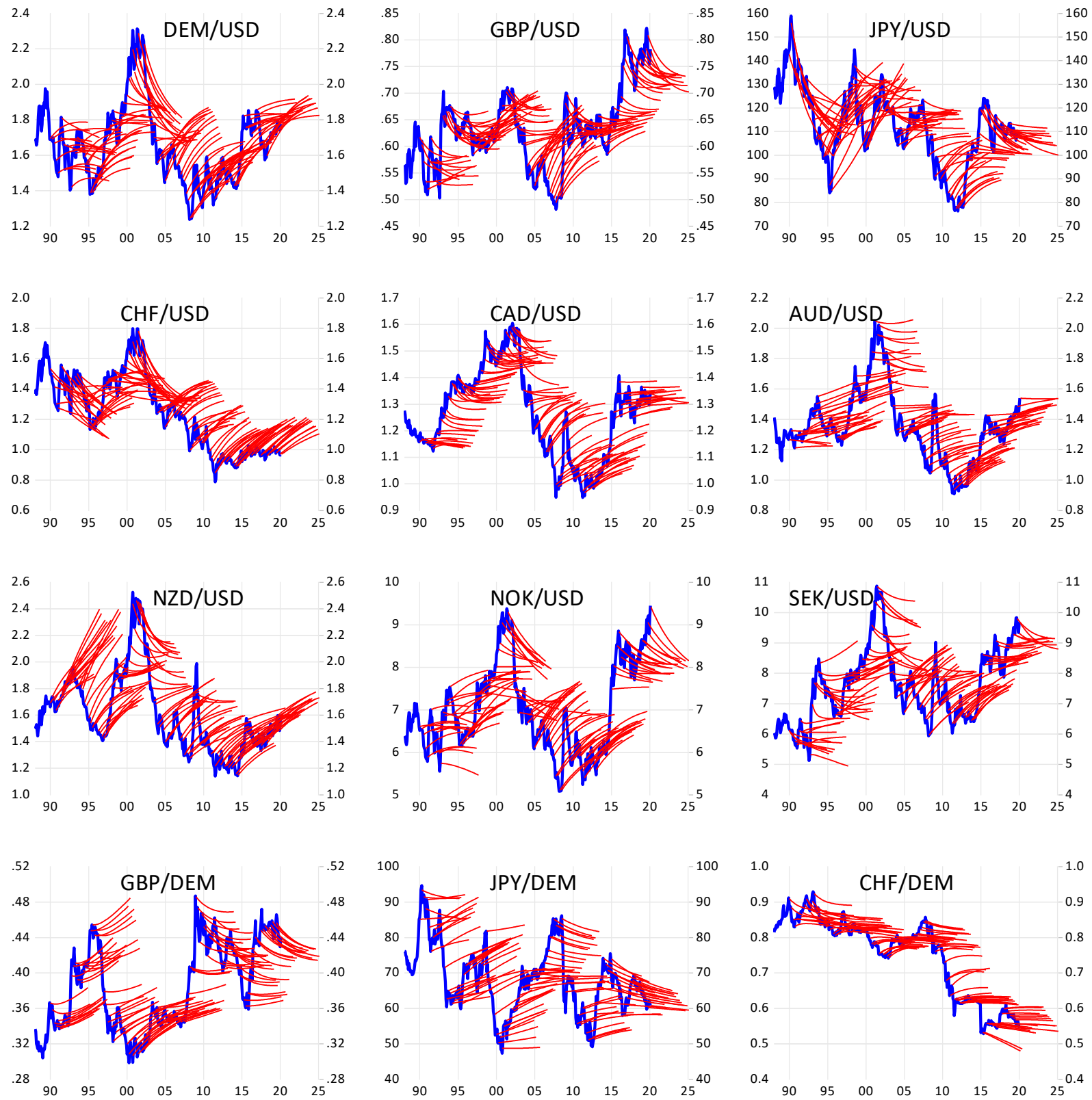

Note: The panels show actual exchange rate movements (blue line in 1988-2020) and out-of-sample forecasts for five years ahead (light red lines), starting, at each date, from the actual exchange rate. The latest forecast was made in February 2020 for the period from March 2020 to February 2025. For better readability, forecasts made only in March, June, September and December of each year are shown, plus the forecast made in February 2020. Although data was used in logarithmic form for estimation and forecasting, panels of this figure show data in their natural units (the price of one US dollar in terms of the other currencies in the first nine panel and the price of one German mark in terms of the other currencies on the last three panels). The combined model was used for all currency pairs, with estimates starting in 1979 for eight currency pairs (corresponding to baseline results in Table 5), not including the Japanese yen/US dollar rate, the New Zealand dollar/UD dollar rate and the Swedish krona/US dollar rate, for which estimation starts in 1985 (corresponding to the second data block in Table 5). 

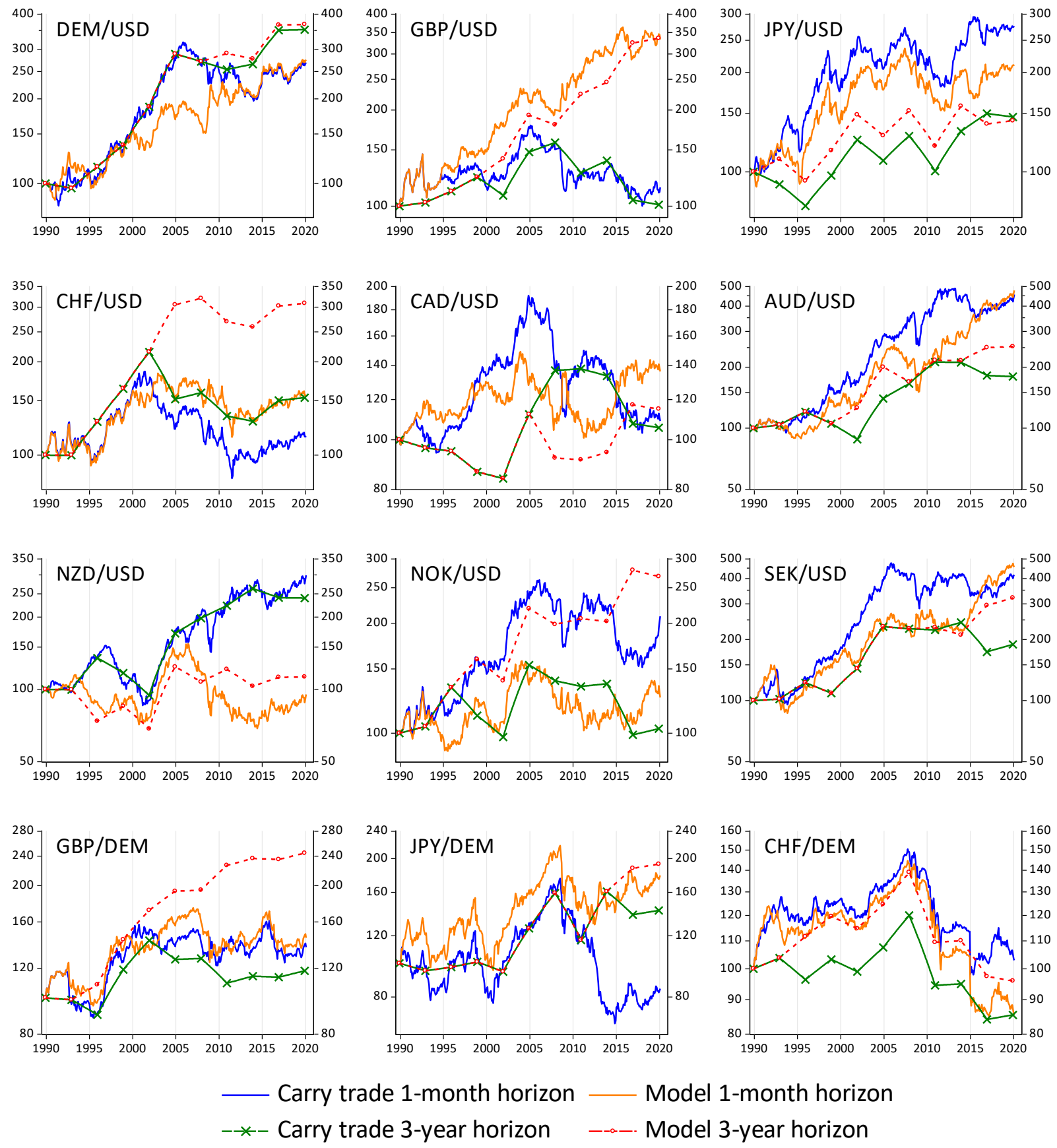

Model 1-month horizon

Model 3-year horizon

Note: The values show the cumulative excess return to investment strategies based on our model (equation (18)) and the carry trade (equation (17)) for an initial 100 investment in December 1989, for monthly reinvestments based on monthly forecasts and three-year reinvestments based non-overlapping three-year forecasts. For our model, the trading strategy based on combined forecasts is used, whereby three forecasts are combined with equal weights from the three models using alternative maturity theoretical forward rates, 3 year, 5 year or 10 years (expect for New Zealand and Sweden, for which the 2 -year maturity rate is used instead of the 3-year maturity rate). 
Table 1: Correlation between the one-period ahead change of the exchange rate and the level of the theoretical forward exchange rate at different data frequencies and corresponding maturity forward rates, DEM/USD rate, January 1979-February 2020

Data frequency and maturity of the theoretical forward rate Min $\quad \max$ average

\begin{tabular}{cccc}
\hline 1 month & & & -0.081 \\
\hline 3 months & -0.152 & -0.143 & -0.148 \\
\hline 1 year & -0.363 & -0.300 & -0.330 \\
\hline 3 years & -0.702 & -0.525 & -0.618 \\
\hline 5 years & -0.961 & -0.491 & -0.797 \\
\hline \hline
\end{tabular}

Notes: Correlation between $\mathrm{s}_{\mathrm{t}+1}-\mathrm{s}_{\mathrm{t}}$ and $\mathrm{d}_{\mathrm{t}}^{(1)}$ for different data frequencies and corresponding maturity forward rates. For example, for the 3-month frequency we sample the data in every third month and use the 3-month theoretical forward rate; for the annual frequency we sample the data in every year and use the 1-year theoretical forward rate, and so. Using our underlying monthly dataset (see the description in Section 4.1), we consider all possible sampling, that is, 3 versions for the 3-month frequency, 12 versions for the annual frequency, 36 versions for the 3 -year frequency and 60 versions for the 5year frequency, and report the minimum, the maximum and the average of the correlation coefficients calculated on these alternative data samples. The monthly frequency calculation is based on 493 observations, while the 5-year frequency calculations are based on either 8 or 7 observations in the January 1979 - February 2020 period. 
Table 2: Regression statistics of the one period change in the exchange rate on the previous period forward rate

\begin{tabular}{|c|c|c|c|c|c|c|c|c|c|c|c|c|c|c|}
\hline $\begin{array}{l}\text { Maturity } \\
\text { of } \\
\text { forward } \\
\text { rate }\end{array}$ & & $\begin{array}{l}\text { DEM/ } \\
\text { USD }\end{array}$ & $\begin{array}{l}\text { GBP/ } \\
\text { USD }\end{array}$ & $\begin{array}{l}\text { JPY/ } \\
\text { USD }\end{array}$ & $\begin{array}{l}\mathrm{CHF} / \\
\text { USD }\end{array}$ & $\begin{array}{l}\text { CAD/ } \\
\text { USD }\end{array}$ & $\begin{array}{l}\text { AUD/ } \\
\text { USD }\end{array}$ & $\begin{array}{l}\text { NZD/ } \\
\text { USD }\end{array}$ & $\begin{array}{l}\text { NOK/ } \\
\text { USD }\end{array}$ & $\begin{array}{l}\text { SEK/ } \\
\text { USD }\end{array}$ & $\begin{array}{l}\text { GBP/ } \\
\text { DEM }\end{array}$ & $\begin{array}{l}\text { JPY/ } \\
\text { DEM }\end{array}$ & $\begin{array}{l}\text { CHF/ } \\
\text { DEM }\end{array}$ & $\begin{array}{l}\text { USD- } \\
\text { Pool }\end{array}$ \\
\hline \multirow[t]{5}{*}{ 1-month } & $\delta_{1}$ & -0.013 & -0.021 & -0.007 & -0.007 & -0.014 & -0.020 & -0.023 & -0.018 & -0.018 & -0.008 & -0.017 & -0.002 & -0.012 \\
\hline & $\mathrm{t}$ & -1.81 & -2.28 & -1.58 & -1.23 & -1.88 & -2.04 & -2.39 & -1.66 & -1.75 & -1.47 & -2.28 & -0.37 & -5.09 \\
\hline & $\mathrm{R} 2$ & 0.01 & 0.01 & 0.01 & 0.00 & 0.01 & 0.01 & 0.01 & 0.01 & 0.01 & 0.00 & 0.01 & 0.00 & 0.01 \\
\hline & DW & 1.92 & 1.85 & 1.90 & 1.99 & 2.11 & 1.90 & 2.02 & 1.92 & 1.75 & 1.88 & 1.98 & 2.13 & 1.93 \\
\hline & $\mathrm{N}$ & 493 & 493 & 493 & 493 & 493 & 401 & 421 & 409 & 397 & 493 & 493 & 493 & 4093 \\
\hline \multirow[t]{5}{*}{3 -year } & $\delta_{1}$ & -0.021 & -0.030 & -0.009 & -0.013 & -0.017 & -0.019 & -0.025 & -0.019 & -0.030 & -0.012 & -0.016 & -0.002 & -0.017 \\
\hline & $\mathrm{t}$ & -2.56 & -3.04 & -1.96 & -2.06 & -2.16 & -2.67 & -2.92 & -2.40 & -2.43 & -1.95 & -2.26 & -0.32 & -7.05 \\
\hline & $\mathrm{R} 2$ & 0.01 & 0.02 & 0.01 & 0.01 & 0.01 & 0.01 & 0.02 & 0.01 & 0.01 & 0.01 & 0.01 & 0.00 & 0.01 \\
\hline & DW & 1.92 & 1.86 & 1.90 & 2.01 & 2.11 & 1.87 & 2.02 & 1.93 & 1.74 & 1.88 & 1.98 & 2.18 & 1.93 \\
\hline & $\mathrm{N}$ & 493 & 493 & 493 & 445 & 493 & 493 & 419 & 493 & 397 & 493 & 493 & 445 & 4219 \\
\hline \multirow[t]{5}{*}{ 5-year } & $\delta_{1}$ & -0.026 & -0.035 & -0.010 & -0.016 & -0.017 & -0.019 & -0.023 & -0.019 & -0.037 & -0.014 & -0.014 & -0.003 & -0.019 \\
\hline & $\mathrm{t}$ & -3.03 & -3.40 & -2.03 & -2.32 & -2.28 & -2.83 & -2.98 & -2.65 & -2.87 & -2.15 & -2.19 & -0.53 & -7.72 \\
\hline & $\mathrm{R} 2$ & 0.02 & 0.02 & 0.01 & 0.01 & 0.01 & 0.02 & 0.02 & 0.01 & 0.02 & 0.01 & 0.01 & 0.00 & 0.02 \\
\hline & DW & 1.92 & 1.86 & 1.90 & 2.01 & 2.11 & 1.88 & 2.02 & 1.93 & 1.74 & 1.88 & 1.98 & 2.17 & 1.93 \\
\hline & $\mathrm{N}$ & 493 & 493 & 493 & 445 & 493 & 493 & 419 & 493 & 397 & 493 & 493 & 445 & 4219 \\
\hline \multirow[t]{5}{*}{ 10-year } & $\delta_{1}$ & -0.037 & -0.036 & -0.012 & -0.023 & -0.014 & -0.016 & -0.018 & -0.017 & -0.022 & -0.016 & -0.011 & -0.007 & -0.019 \\
\hline & $\mathrm{t}$ & -3.86 & -3.71 & -2.25 & -3.13 & -2.16 & -2.73 & -2.85 & -2.80 & -3.37 & -2.17 & -2.03 & -1.02 & -8.63 \\
\hline & $\mathrm{R} 2$ & 0.03 & 0.03 & 0.01 & 0.02 & 0.01 & 0.01 & 0.02 & 0.02 & 0.02 & 0.01 & 0.01 & 0.00 & 0.02 \\
\hline & DW & 1.93 & 1.87 & 1.90 & 1.99 & 2.11 & 1.88 & 2.03 & 1.94 & 1.83 & 1.87 & 1.99 & 2.13 & 1.93 \\
\hline & $\mathrm{N}$ & 493 & 493 & 493 & 493 & 493 & 493 & 419 & 493 & 493 & 493 & 493 & 493 & 4363 \\
\hline
\end{tabular}

Notes. Equation estimated: $s_{t+1}-s_{t}=\delta_{0}+\delta_{1} f_{t}^{(h)}+\varepsilon_{t+1}$, where $s_{t}$ denotes the spot exchange rate; $f_{t}^{(h)}$ denotes the $h$ period maturity forward rate; $h$ is showed in the first column. t: OLS t-statistics, R2: coefficient of determinant; DW:

Durbin-Watson, N: number of observations. The sample includes monthly data in January 1979 - February 2020 (with a few data-driven exceptions). The maximum number of observations is 493 for currency pairs and 4437 for the panel. 
Table 3: 95 percent confidence interval of the slope parameter of the one-period regression for alternative maturities of the forward rate, using the local-to-unity robust estimator of Rossi (2007)

\begin{tabular}{|c|c|c|c|c|c|c|c|c|c|c|c|c|}
\hline & $\begin{array}{l}\text { DEM/ } \\
\text { USD }\end{array}$ & $\begin{array}{l}\text { GBP/ } \\
\text { USD }\end{array}$ & $\begin{array}{l}\text { JPY/ } \\
\text { USD }\end{array}$ & $\begin{array}{l}\text { CHF/ } \\
\text { USD }\end{array}$ & $\begin{array}{l}\text { CAD/ } \\
\text { USD }\end{array}$ & $\begin{array}{l}\text { AUD/ } \\
\text { USD }\end{array}$ & $\begin{array}{l}\text { NZD/ } \\
\text { USD }\end{array}$ & $\begin{array}{c}\text { NOK/ } \\
\text { USD }\end{array}$ & $\begin{array}{l}\text { SEK/ } \\
\text { USD }\end{array}$ & $\begin{array}{c}\text { GBP } \\
/ \text { DEM }\end{array}$ & $\begin{array}{l}\text { JPY/ } \\
\text { DEM }\end{array}$ & $\begin{array}{l}\text { CHF/ } \\
\text { DEM }\end{array}$ \\
\hline \multicolumn{13}{|c|}{ Regressor: 1-month forward rate } \\
\hline Upper & 0.0016 & 0.0064 & 0.0072 & 0.0068 & 0.0022 & 0.0050 & 0.0068 & 0.0032 & 0.0073 & 0.0073 & 0.0071 & 0.0084 \\
\hline Lower & -0.0248 & -0.0101 & -0.0055 & -0.0078 & -0.0241 & -0.0225 & -0.0150 & -0.0285 & -0.0178 & -0.0055 & -0.0066 & -0.0016 \\
\hline \multicolumn{13}{|c|}{ Regressor: 3-year forward rate } \\
\hline Upper & -0.0037 & 0.0027 & 0.0060 & 0.0064 & 0.0018 & 0.0070 & 0.0070 & 0.0077 & 0.0010 & 0.0054 & 0.0086 & 0.0099 \\
\hline Lower & -0.0390 & -0.0271 & -0.0108 & -0.0120 & -0.0297 & -0.0138 & -0.0170 & -0.0142 & -0.0398 & -0.0147 & -0.0095 & -0.0075 \\
\hline \multicolumn{13}{|c|}{ Regressor: 5-year forward rate } \\
\hline Upper & -0.0083 & 0.0003 & 0.0058 & 0.0039 & -0.0002 & 0.0057 & 0.0059 & 0.0054 & -0.0069 & 0.0038 & 0.0085 & 0.0096 \\
\hline Lower & -0.0468 & -0.0358 & -0.0126 & -0.0177 & -0.0326 & -0.0169 & -0.0187 & -0.0185 & -0.0593 & -0.0210 & -0.0108 & -0.0117 \\
\hline \multicolumn{13}{|c|}{ Regressor: 10 -year forward rate } \\
\hline Upper & -0.0169 & -0.0103 & 0.0044 & -0.0067 & 0.0020 & 0.0041 & 0.0041 & 0.0022 & -0.0006 & -0.0001 & 0.0068 & 0.0090 \\
\hline Lower & -0.0599 & -0.0531 & -0.0159 & -0.0393 & -0.0254 & -0.0176 & -0.0180 & -0.0212 & -0.0260 & -0.0328 & -0.0136 & -0.0193 \\
\hline
\end{tabular}

Notes. Equation estimated: $s_{t+1}-s_{t}=\delta_{0}+\delta_{1} f_{t}^{(h)}+\varepsilon_{t+1}$, where $s_{t}$ denotes the spot exchange rate; $f_{t}^{(h)}$ denotes the $h$ period maturity forward rate. The sample includes monthly data in January 1979 - February 2020 (with a few data-driven exceptions). 
Table 4: Out-of-sample forecast evaluation, baseline results for DEM/USD

Full sample, different forecast horizons

Different samples, 36M forecast horizon

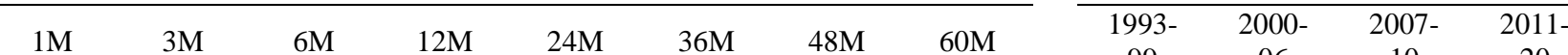

Mean squared forecast error (MSFE), random walk without drift $=100$

\begin{tabular}{lrrrrrrrrrrrrrr}
\hline Forward & 100.71 & 101.92 & 103.71 & 107.93 & 113.30 & 116.93 & 112.15 & 105.41 & 148.75 & 117.12 & 70.01 & 102.93 \\
$\mathrm{p}$ & $(0.846)$ & $(0.866)$ & $(0.920)$ & $(0.984)$ & $(0.999)$ & $(1.000)$ & $(0.988)$ & $(0.876)$ & $(1.000)$ & $(1.000)$ & $(0.002)$ & $(0.713)$ \\
\hline Model 3Y & 99.63 & 98.99 & 97.71 & 92.61 & 84.13 & 73.41 & 67.74 & 62.31 & 57.15 & 56.52 & 279.56 & 44.45 \\
p (BS) & $(0.031)$ & $(0.037)$ & $(0.028)$ & $(0.021)$ & $(0.017)$ & $(0.010)$ & $(0.015)$ & $(0.015)$ & $(0.042)$ & $(0.041)$ & $(0.940)$ & $(0.012)$ \\
p (CW) & $(0.115)$ & $(0.102)$ & $(0.073)$ & $(0.012)$ & $(0.001)$ & $(0.000)$ & $(0.000)$ & $(0.000)$ & $(0.002)$ & $(0.000)$ & $(0.999)$ & $(0.000)$ \\
\hline Model 5Y & 99.44 & 98.58 & 96.65 & 90.32 & 79.93 & 68.39 & 62.29 & 55.94 & 42.39 & 44.47 & 336.61 & 42.74 \\
p (BS) & $(0.032)$ & $(0.039)$ & $(0.035)$ & $(0.019)$ & $(0.012)$ & $(0.012)$ & $(0.013)$ & $(0.011)$ & $(0.017)$ & $(0.029)$ & $(0.965)$ & $(0.009)$ \\
p (CW) & $(0.057)$ & $(0.051)$ & $(0.032)$ & $(0.005)$ & $(0.001)$ & $(0.000)$ & $(0.000)$ & $(0.000)$ & $(0.000)$ & $(0.000)$ & $(0.999)$ & $(0.000)$ \\
\hline Model 10Y & 99.90 & 100.09 & 98.40 & 91.40 & 78.74 & 72.35 & 69.47 & 64.57 & 60.73 & 45.49 & 319.35 & 50.36 \\
p (BS) & $(0.078)$ & $(0.110)$ & $(0.055)$ & $(0.015)$ & $(0.006)$ & $(0.009)$ & $(0.017)$ & $(0.020)$ & $(0.067)$ & $(0.014)$ & $(0.969)$ & $(0.010)$ \\
p (CW) & $(0.017)$ & $(0.019)$ & $(0.011)$ & $(0.002)$ & $(0.001)$ & $(0.001)$ & $(0.000)$ & $(0.000)$ & $(0.000)$ & $(0.001)$ & $(0.998)$ & $(0.000)$ \\
\hline Combined & 99.23 & 98.18 & 95.85 & 88.76 & 77.49 & 67.49 & 62.54 & 57.02 & 44.10 & 46.18 & 310.51 & 43.04 \\
p (BS) & $(0.026)$ & $(0.034)$ & $(0.026)$ & $(0.008)$ & $(0.009)$ & $(0.006)$ & $(0.005)$ & $(0.005)$ & $(0.019)$ & $(0.022)$ & $(0.979)$ & $(0.006)$ \\
p (CW) & $(0.035)$ & $(0.034)$ & $(0.021)$ & $(0.003)$ & $(0.001)$ & $(0.000)$ & $(0.000)$ & $(0.000)$ & $(0.000)$ & $(0.000)$ & $(0.999)$ & $(0.000)$ \\
\hline
\end{tabular}

Correct sign prediction compared to the spot rate, $\%$

\begin{tabular}{lrrrrrrrrrrrr}
\hline Forward & 47.2 & 46.7 & 38.9 & 43.6 & 40.4 & 39.1 & 44.4 & 46.9 & 17.9 & 20.2 & 79.2 & 51.8 \\
$\mathrm{p}$ & $(0.860)$ & $(0.918)$ & $(1.000)$ & $(0.990)$ & $(1.000)$ & $(1.000)$ & $(0.963)$ & $(0.802)$ & $(1.000)$ & $(1.000)$ & $(0.013)$ & $(0.101)$ \\
\hline Model 3Y & 53.0 & 51.9 & 54.3 & 57.5 & 61.9 & 65.7 & 69.5 & 68.6 & 53.6 & 88.1 & 18.8 & 79.1 \\
$\mathrm{p}$ & $(0.039)$ & $(0.036)$ & $(0.009)$ & $(0.000)$ & $(0.000)$ & $(0.000)$ & $(0.000)$ & $(0.000)$ & n.a. & $(0.000)$ & n.a. & $(0.000)$ \\
\hline Model 5Y & 52.2 & 50.6 & 54.3 & 58.1 & 60.2 & 65.4 & 69.8 & 70.6 & 63.1 & 86.9 & 18.8 & 71.8 \\
$\mathrm{p}$ & $(0.086)$ & $(0.137)$ & $(0.008)$ & $(0.000)$ & $(0.000)$ & $(0.000)$ & $(0.000)$ & $(0.000)$ & $(0.001)$ & $(0.000)$ & n.a. & $(0.000)$ \\
\hline Model 10Y & 51.7 & 52.8 & 57.1 & 59.5 & 62.2 & 66.4 & 66.3 & 68.6 & 85.7 & 67.9 & 18.8 & 71.8 \\
$\mathrm{p}$ & $(0.228)$ & $(0.067)$ & $(0.001)$ & $(0.000)$ & $(0.000)$ & $(0.000)$ & $(0.000)$ & $(0.000)$ & $(0.000)$ & $(0.001)$ & n.a. & $(0.000)$ \\
\hline Combined & 52.2 & 51.1 & 55.5 & 61.0 & 60.2 & 65.1 & 69.5 & 69.3 & 73.8 & 77.4 & 18.8 & 70.0 \\
$\mathrm{p}$ & $(0.127)$ & $(0.137)$ & $(0.004)$ & $(0.000)$ & $(0.000)$ & $(0.000)$ & $(0.000)$ & $(0.000)$ & $(0.000)$ & $(0.000)$ & n.a. & n.a. \\
\hline
\end{tabular}

Correct sign prediction compared to the forward rate, $\%$

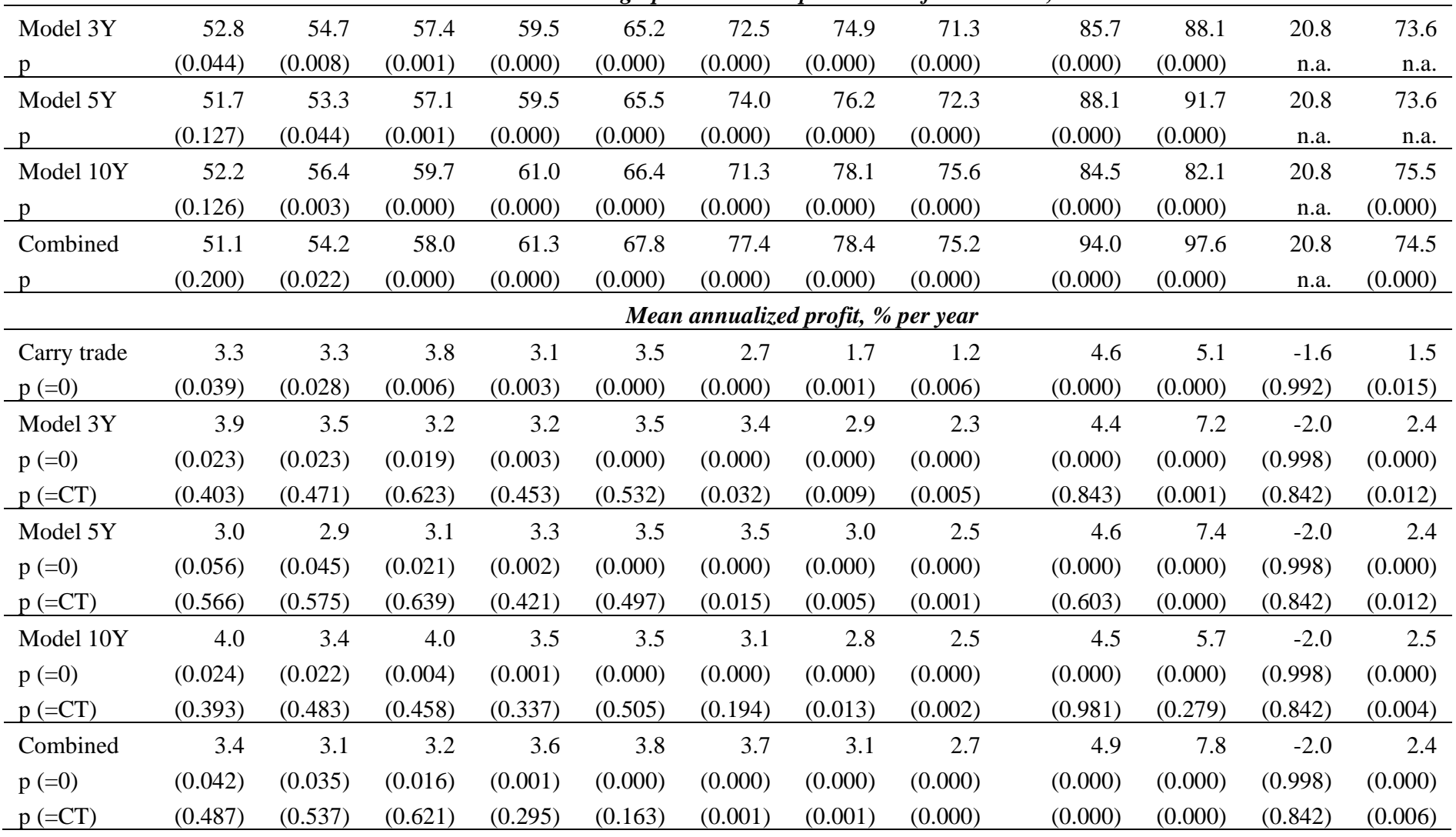


Notes: The sample period includes monthly data from January 1979 to February 2020. Using the recursive estimation window, out-of-sample evaluation of forecasts was performed in the 1990-2020 period except in the last four data columns, for which the evaluation period is indicated in the heading. For MSFE, $p$ (BS) is the bootstrap p value of testing the null hypothesis that the model MSFE is the same as that of the random walk against the one-sided alternative hypothesis that the model is better, based on 1000 bootstrap draws. $\mathrm{p}(\mathrm{CW})$ is the p-value of the same null hypothesis based on the test of Clark and West $(2006,2007)$. The p value for the sign predictions are based on the test of Pesaran and Timmermann (1992). This test assumes that both the predictor and the outcome change sign in the forecast evaluation period, which assumption is not satisfied for some of the sub-periods we consider. For the mean annualized profit, $\mathrm{p}(=0)$ is the $\mathrm{p}$ value of the null hypothesis that the Sharpe-ratio is zero against the one-sided alterative that it is positive, while $p(=C T)$ the $p$ value of the null hypothesis that the Sharpe-ratio of our model-based forecast is the same as the Sharpe-ratio of the carry trade strategy, against the one-sided alterative that the Sharpe-ratio based on our model is larger. See the results for other currency pairs in Table A3 of the appendices. 
Table 5: Sensitivity analysis, out-of-sample forecast evaluation, mean squared forecast error (random walk = 100)

DEM/USD

Full sample, different forecast horizons

$1 \mathrm{M}$

\begin{tabular}{|c|c|c|c|c|c|c|c|c|c|c|c|c|}
\hline A) Baseline & $\begin{array}{r}99.2 \\
(0.035) \\
\end{array}$ & $\begin{array}{r}98.2 \\
(0.034) \\
\end{array}$ & $\begin{array}{r}95.9 \\
(0.021) \\
\end{array}$ & $\begin{array}{r}88.8 \\
(0.003) \\
\end{array}$ & $\begin{array}{r}77.5 \\
(0.001) \\
\end{array}$ & $\begin{array}{r}67.5 \\
(0.000) \\
\end{array}$ & $\begin{array}{r}62.5 \\
(0.000) \\
\end{array}$ & $\begin{array}{r}57.0 \\
(0.000) \\
\end{array}$ & $\begin{array}{r}44.1 \\
(0.000) \\
\end{array}$ & $\begin{array}{r}46.2 \\
(0.000) \\
\end{array}$ & $\begin{array}{r}310.5 \\
(0.999) \\
\end{array}$ & $\begin{array}{r}43.0 \\
(0.000) \\
\end{array}$ \\
\hline $\begin{array}{c}\text { B) Estimation } \\
\text { sample starts in } \\
1985\end{array}$ & $\begin{array}{r}100.2 \\
(0.024) \\
\end{array}$ & $\begin{array}{r}100.5 \\
(0.021) \\
\end{array}$ & $\begin{array}{r}99.0 \\
(0.011) \\
\end{array}$ & $\begin{array}{r}93.2 \\
(0.003) \\
\end{array}$ & $\begin{array}{r}80.0 \\
(0.001) \\
\end{array}$ & $\begin{array}{r}72.2 \\
(0.001) \\
\end{array}$ & $\begin{array}{r}68.4 \\
(0.000) \\
\end{array}$ & $\begin{array}{r}64.6 \\
(0.000) \\
\end{array}$ & $\begin{array}{r}76.1 \\
(0.000) \\
\end{array}$ & $\begin{array}{r}52.0 \\
(0.002) \\
\end{array}$ & $\begin{array}{r}266.6 \\
(0.995) \\
\end{array}$ & $\begin{array}{r}37.1 \\
(0.000) \\
\end{array}$ \\
\hline C) Panel & $\begin{array}{r}99.0 \\
(0.037) \\
\end{array}$ & $\begin{array}{r}97.5 \\
(0.035) \\
\end{array}$ & $\begin{array}{r}95.0 \\
(0.022) \\
\end{array}$ & $\begin{array}{r}89.3 \\
(0.003) \\
\end{array}$ & $\begin{array}{r}81.1 \\
(0.001) \\
\end{array}$ & $\begin{array}{r}73.3 \\
(0.000) \\
\end{array}$ & $\begin{array}{r}69.4 \\
(0.000) \\
\end{array}$ & $\begin{array}{r}65.7 \\
(0.000) \\
\end{array}$ & $\begin{array}{r}60.2 \\
(0.000) \\
\end{array}$ & $\begin{array}{r}62.7 \\
(0.000) \\
\end{array}$ & $\begin{array}{r}220.5 \\
(0.998) \\
\end{array}$ & $\begin{array}{r}50.2 \\
(0.000) \\
\end{array}$ \\
\hline $\begin{array}{l}\text { D) Alternative } \\
\text { model }\end{array}$ & $\begin{array}{r}97.8 \\
(0.008) \\
\end{array}$ & $\begin{array}{r}97.8 \\
(0.026) \\
\end{array}$ & $\begin{array}{r}95.8 \\
(0.024) \\
\end{array}$ & $\begin{array}{r}89.3 \\
(0.004) \\
\end{array}$ & $\begin{array}{r}79.1 \\
(0.001) \\
\end{array}$ & $\begin{array}{r}70.2 \\
(0.000) \\
\end{array}$ & $\begin{array}{r}65.7 \\
(0.000) \\
\end{array}$ & $\begin{array}{r}61.2 \\
(0.000) \\
\end{array}$ & $\begin{array}{r}51.8 \\
(0.000) \\
\end{array}$ & $\begin{array}{r}51.6 \\
(0.000) \\
\end{array}$ & $\begin{array}{r}288.7 \\
(0.999) \\
\end{array}$ & $\begin{array}{r}43.5 \\
(0.000) \\
\end{array}$ \\
\hline $\begin{array}{l}\text { E) Unit root in } \\
\text { forward rates }\end{array}$ & $\begin{array}{r}99.2 \\
(0.035) \\
\end{array}$ & $\begin{array}{r}98.3 \\
(0.035) \\
\end{array}$ & $\begin{array}{r}96.5 \\
(0.022) \\
\end{array}$ & $\begin{array}{r}90.6 \\
(0.003) \\
\end{array}$ & $\begin{array}{r}83.6 \\
(0.001) \\
\end{array}$ & $\begin{array}{r}79.4 \\
(0.000) \\
\end{array}$ & $\begin{array}{r}83.4 \\
(0.000) \\
\end{array}$ & $\begin{array}{r}82.8 \\
(0.000) \\
\end{array}$ & $\begin{array}{r}34.5 \\
(0.000) \\
\end{array}$ & $\begin{array}{r}29.9 \\
(0.000) \\
\end{array}$ & $\begin{array}{r}542.6 \\
(0.999) \\
\end{array}$ & $\begin{array}{r}60.4 \\
(0.000) \\
\end{array}$ \\
\hline F) VAR in levels & $\begin{array}{r}103.3 \\
(0.073) \\
\end{array}$ & $\begin{array}{r}109.3 \\
(0.115) \\
\end{array}$ & $\begin{array}{r}111.3 \\
(0.066) \\
\end{array}$ & $\begin{array}{r}105.5 \\
(0.010) \\
\end{array}$ & $\begin{array}{r}84.9 \\
(0.001) \\
\end{array}$ & $\begin{array}{r}68.8 \\
(0.000) \\
\end{array}$ & $\begin{array}{r}63.0 \\
(0.000) \\
\end{array}$ & $\begin{array}{r}62.1 \\
(0.000) \\
\end{array}$ & $\begin{array}{r}59.4 \\
(0.000) \\
\end{array}$ & $\begin{array}{r}37.1 \\
(0.000) \\
\end{array}$ & $\begin{array}{r}353.3 \\
(0.999) \\
\end{array}$ & $\begin{array}{r}40.8 \\
(0.000) \\
\end{array}$ \\
\hline
\end{tabular}

GBP/USD

\begin{tabular}{|c|c|c|c|c|c|c|c|c|c|c|c|c|}
\hline & & \multicolumn{4}{|c|}{ 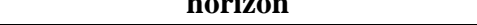 } \\
\hline & $1 \mathrm{M}$ & $3 \mathrm{M}$ & $6 \mathrm{M}$ & $12 \mathrm{M}$ & $24 \mathrm{M}$ & $36 \mathrm{M}$ & $48 \mathrm{M}$ & $60 \mathrm{M}$ & $\begin{array}{c}1993- \\
99 \\
\end{array}$ & $\begin{array}{c}2000- \\
06\end{array}$ & $\begin{array}{c}2007- \\
10 \\
\end{array}$ & $\begin{array}{c}2011- \\
20 \\
\end{array}$ \\
\hline \multirow{2}{*}{ A) Baseline } & 99.5 & 97.4 & 93.2 & 90.9 & 80.2 & 75.4 & 70.1 & 71.1 & 91.9 & 71.1 & 67.4 & 75.6 \\
\hline & $(0.030)$ & $(0.011)$ & $(0.005)$ & $(0.009)$ & $(0.001)$ & $(0.000)$ & $(0.000)$ & $(0.000)$ & $(0.020)$ & $(0.000)$ & $(0.008)$ & $(0.005)$ \\
\hline \multirow{2}{*}{$\begin{array}{c}\text { B) Estimation } \\
\text { sample starts in } \\
1985\end{array}$} & 100.7 & 99.8 & 95.9 & 97.7 & 90.2 & 92.7 & 90.1 & 94.8 & 170.5 & 60.6 & 68.3 & 96.7 \\
\hline & $(0.030)$ & $(0.011)$ & $(0.004)$ & $(0.009)$ & $(0.003)$ & $(0.004)$ & $(0.002)$ & $(0.003)$ & $(0.814)$ & $(0.000)$ & $(0.008)$ & $(0.050)$ \\
\hline \multirow{2}{*}{ C) Panel } & 99.4 & 97.7 & 95.0 & 92.1 & 83.9 & 79.6 & 76.2 & 76.6 & 89.8 & 89.3 & 63.3 & 75.0 \\
\hline & $(0.031)$ & $(0.015)$ & $(0.008)$ & $(0.013)$ & $(0.003)$ & $(0.001)$ & $(0.000)$ & $(0.000)$ & $(0.041)$ & $(0.005)$ & $(0.009)$ & $(0.001)$ \\
\hline \multirow{2}{*}{$\begin{array}{l}\text { D) Alternative } \\
\text { model }\end{array}$} & 99.3 & 97.0 & 93.3 & 91.2 & 80.5 & 75.1 & 70.5 & 71.9 & 86.2 & 74.9 & 65.4 & 75.5 \\
\hline & $(0.038)$ & $(0.012)$ & $(0.005)$ & $(0.009)$ & $(0.001)$ & $(0.000)$ & $(0.000)$ & $(0.000)$ & $(0.009)$ & $(0.000)$ & $(0.008)$ & $(0.004)$ \\
\hline \multirow{2}{*}{$\begin{array}{l}\text { E) Unit root in } \\
\text { forward rates }\end{array}$} & 99.5 & 97.5 & 93.3 & 92.8 & 86.9 & 95.6 & 100.3 & 126.4 & 148.3 & 54.4 & 121.0 & 86.7 \\
\hline & $(0.030)$ & $(0.011)$ & $(0.005)$ & $(0.009)$ & $(0.001)$ & $(0.000)$ & $(0.000)$ & $(0.000)$ & $(0.049)$ & $(0.000)$ & $(0.009)$ & $(0.010)$ \\
\hline \multirow{2}{*}{ F) VAR in levels } & 101.8 & 103.4 & 99.7 & 97.9 & 79.5 & 70.8 & 62.8 & 58.2 & 48.8 & 58.1 & 67.2 & 100.6 \\
\hline & $(0.305)$ & $(0.278)$ & $(0.091)$ & $(0.042)$ & $(0.001)$ & $(0.000)$ & $(0.000)$ & $(0.000)$ & $(0.000)$ & $(0.000)$ & $(0.013)$ & $(0.092)$ \\
\hline
\end{tabular}

Different samples, 36M forecast horizon

1993- 2000- 2007- 2011-

$\begin{array}{cccc}99 & 06 & 10 & 20\end{array}$




\begin{tabular}{|c|c|c|c|c|c|c|c|c|c|c|c|c|}
\hline & $1 \mathrm{M}$ & $3 \mathrm{M}$ & $6 \mathrm{M}$ & $12 \mathrm{M}$ & $24 \mathrm{M}$ & $36 \mathrm{M}$ & $48 \mathrm{M}$ & $60 \mathrm{M}$ & $\begin{array}{c}1993- \\
99\end{array}$ & $\begin{array}{c}2000- \\
06\end{array}$ & $\begin{array}{c}2007- \\
10\end{array}$ & $\begin{array}{c}2011- \\
20\end{array}$ \\
\hline \multirow{2}{*}{ A) Baseline } & 100.7 & 103.0 & 105.9 & 111.0 & 108.2 & 103.6 & 106.7 & 111.8 & 30.6 & 38.0 & 289.1 & 277.1 \\
\hline & $(0.128)$ & $(0.170)$ & $(0.139)$ & $(0.078)$ & $(0.015)$ & $(0.005)$ & $(0.005)$ & $(0.008)$ & $(0.000)$ & $(0.000)$ & $(1.000)$ & $(0.680)$ \\
\hline \multirow{2}{*}{$\begin{array}{c}\text { B) Estimation } \\
\text { sample starts in } \\
1985 \\
\end{array}$} & 101.7 & 106.2 & 111.7 & 122.1 & 120.3 & 115.0 & 115.1 & 118.8 & 40.2 & 35.9 & 305.2 & 321.0 \\
\hline & $(0.090)$ & $(0.113)$ & $(0.084)$ & $(0.047)$ & $(0.009)$ & $(0.003)$ & $(0.002)$ & $(0.002)$ & $(0.000)$ & $(0.001)$ & $(1.000)$ & $(0.657)$ \\
\hline \multirow{2}{*}{ C) Panel } & 99.8 & 100.1 & 100.2 & 100.5 & 96.4 & 91.3 & 90.4 & 92.8 & 64.5 & 59.6 & 171.7 & 166.6 \\
\hline & $(0.092)$ & $(0.122)$ & $(0.089)$ & $(0.046)$ & $(0.010)$ & $(0.004)$ & $(0.002)$ & $(0.003)$ & $(0.000)$ & $(0.001)$ & (1.000) & $(0.378)$ \\
\hline \multirow{2}{*}{$\begin{array}{l}\text { D) Alternative } \\
\text { model }\end{array}$} & 99.7 & 101.7 & 105.1 & 108.7 & 105.3 & 100.3 & 102.6 & 107.6 & 39.3 & 41.1 & 277.0 & 242.9 \\
\hline & $(0.036)$ & $(0.102)$ & $(0.155)$ & $(0.086)$ & $(0.018)$ & $(0.008)$ & $(0.007)$ & $(0.010)$ & $(0.000)$ & $(0.000)$ & $(1.000)$ & $(0.700)$ \\
\hline \multirow{2}{*}{$\begin{array}{l}\text { E) Unit root in } \\
\text { forward rates }\end{array}$} & 100.7 & 103.2 & 107.2 & 117.1 & 129.5 & 146.3 & 178.2 & 215.8 & 22.8 & 30.1 & 452.4 & 457.3 \\
\hline & $(0.128)$ & $(0.171)$ & $(0.143)$ & $(0.086)$ & $(0.020)$ & $(0.008)$ & $(0.012)$ & $(0.021)$ & $(0.000)$ & $(0.000)$ & $(1.000)$ & $(0.771)$ \\
\hline \multirow{2}{*}{ F) VAR in levels } & 103.6 & 114.1 & 126.1 & 144.3 & 143.1 & 133.1 & 145.1 & 162.2 & 41.8 & 26.8 & 420.0 & 377.2 \\
\hline & $(0.116)$ & $(0.219)$ & $(0.180)$ & (0.069) & $(0.007)$ & $(0.002)$ & $(0.012)$ & $(0.104)$ & $(0.000)$ & $(0.000)$ & (1.000) & $(0.640)$ \\
\hline
\end{tabular}

\section{NOK/USD}

\begin{tabular}{|c|c|c|c|c|c|c|c|c|c|c|c|c|}
\hline & & \\
\hline & $1 \mathrm{M}$ & $3 \mathrm{M}$ & $6 \mathrm{M}$ & $12 \mathrm{M}$ & $24 \mathrm{M}$ & $36 \mathrm{M}$ & $48 \mathrm{M}$ & $60 \mathrm{M}$ & $\begin{array}{c}1993- \\
99\end{array}$ & $\begin{array}{c}2000- \\
06\end{array}$ & $\begin{array}{c}2007- \\
10\end{array}$ & $\begin{array}{c}2011- \\
20\end{array}$ \\
\hline \multirow{2}{*}{ A) Baseline } & 99.6 & 98.9 & 97.4 & 93.7 & 85.9 & 76.5 & 68.6 & 66.1 & 58.8 & 61.7 & 242.8 & 66.7 \\
\hline & $(0.119)$ & $(0.115)$ & $(0.082)$ & $(0.022)$ & $(0.001)$ & $(0.000)$ & $(0.000)$ & $(0.000)$ & $(0.000)$ & $(0.000)$ & $(0.968)$ & $(0.000)$ \\
\hline \multirow{2}{*}{$\begin{array}{c}\text { B) Estimation } \\
\text { sample starts in } \\
1985 \\
\end{array}$} & 100.9 & 102.4 & 103.5 & 99.8 & 91.8 & 77.4 & 67.9 & 69.3 & 54.6 & 38.9 & 365.1 & 68.1 \\
\hline & $(0.236)$ & $(0.250)$ & $(0.200)$ & $(0.045)$ & $(0.004)$ & $(0.000)$ & $(0.000)$ & $(0.000)$ & $(0.000)$ & $(0.000)$ & $(0.979)$ & $(0.000)$ \\
\hline \multirow{2}{*}{ C) Panel } & 99.5 & 98.7 & 97.0 & 93.2 & 85.5 & 76.0 & 68.2 & 65.8 & 57.1 & 59.1 & 246.7 & 67.7 \\
\hline & $(0.109)$ & $(0.104)$ & $(0.073)$ & $(0.020)$ & $(0.001)$ & $(0.000)$ & $(0.000)$ & $(0.000)$ & $(0.000)$ & $(0.000)$ & $(0.967)$ & $(0.000)$ \\
\hline \multirow{2}{*}{$\begin{array}{l}\text { D) Alternative } \\
\text { model }\end{array}$} & 99.6 & 99.1 & 97.6 & 94.4 & 87.4 & 79.0 & 72.3 & 70.6 & 61.2 & 69.2 & 226.4 & 68.3 \\
\hline & $(0.148)$ & $(0.128)$ & $(0.087)$ & $(0.025)$ & $(0.002)$ & $(0.000)$ & $(0.000)$ & $(0.000)$ & $(0.000)$ & $(0.000)$ & $(0.970)$ & $(0.000)$ \\
\hline \multirow{2}{*}{$\begin{array}{l}\text { E) Unit root in } \\
\text { forward rates }\end{array}$} & 99.6 & 98.9 & 97.5 & 93.9 & 86.5 & 76.6 & 67.0 & 64.1 & 47.3 & 52.8 & 344.3 & 61.1 \\
\hline & $(0.119)$ & $(0.115)$ & $(0.083)$ & $(0.023)$ & $(0.001)$ & $(0.000)$ & $(0.000)$ & $(0.000)$ & $(0.000)$ & $(0.000)$ & $(0.971)$ & $(0.000)$ \\
\hline \multirow{2}{*}{ F) VAR in levels } & 100.1 & 100.6 & 99.7 & 96.1 & 87.5 & 77.4 & 67.4 & 59.6 & 55.4 & 67.6 & 209.2 & 71.0 \\
\hline & $(0.283)$ & $(0.319)$ & $(0.198)$ & $(0.053)$ & $(0.002)$ & $(0.000)$ & $(0.000)$ & $(0.000)$ & $(0.000)$ & $(0.002)$ & $(0.937)$ & $(0.001)$ \\
\hline
\end{tabular}

Full sample, different forecast horizons

\begin{tabular}{|c|c|c|c|c|c|c|c|c|c|c|c|c|}
\hline \multirow[t]{2}{*}{ SEN/UDD } & \multicolumn{8}{|c|}{ ruit sampie, anterent iorecast horzzons } & \multicolumn{4}{|c|}{ horizon } \\
\hline & $1 \mathrm{M}$ & $3 \mathrm{M}$ & $6 \mathrm{M}$ & $12 \mathrm{M}$ & $24 \mathrm{M}$ & $36 \mathrm{M}$ & $48 \mathrm{M}$ & $60 \mathrm{M}$ & $\begin{array}{c}1993- \\
99\end{array}$ & $\begin{array}{c}2000- \\
06\end{array}$ & $\begin{array}{c}2007- \\
10 \\
\end{array}$ & $\begin{array}{c}2011- \\
20\end{array}$ \\
\hline \multirow{2}{*}{ A) Baseline } & 100.2 & 98.4 & 93.9 & 89.8 & 83.7 & 85.1 & 80.1 & 80.0 & 99.6 & 70.5 & 247.3 & 61.5 \\
\hline & $(0.265)$ & $(0.061)$ & $(0.015)$ & $(0.004)$ & $(0.000)$ & $(0.000)$ & $(0.000)$ & $(0.000)$ & $(0.207)$ & $(0.000)$ & $(0.751)$ & $(0.001)$ \\
\hline \multirow{2}{*}{$\begin{array}{l}\text { B) Estimation } \\
\text { sample starts in } \\
1985\end{array}$} & 100.6 & 99.1 & 94.5 & 89.3 & 82.3 & 87.8 & 85.9 & 86.9 & 110.8 & 63.2 & 293.0 & 61.2 \\
\hline & $(0.246)$ & $(0.066)$ & $(0.015)$ & $(0.003)$ & $(0.000)$ & $(0.001)$ & $(0.000)$ & $(0.001)$ & $(0.423)$ & $(0.000)$ & $(0.775)$ & $(0.001)$ \\
\hline \multirow{2}{*}{ C) Panel } & 99.2 & 98.0 & 95.8 & 91.9 & 85.2 & 87.7 & 85.3 & 85.8 & 113.3 & 66.1 & 218.8 & 66.7 \\
\hline & $(0.062)$ & $(0.057)$ & $(0.032)$ & $(0.007)$ & $(0.000)$ & $(0.002)$ & $(0.001)$ & $(0.001)$ & $(0.751)$ & $(0.000)$ & $(0.771)$ & $(0.001)$ \\
\hline \multirow{2}{*}{$\begin{array}{l}\text { D) Alternative } \\
\text { model }\end{array}$} & 99.0 & 99.7 & 95.7 & 90.3 & 82.0 & 84.2 & 79.6 & 80.4 & 105.9 & 61.3 & 270.2 & 60.6 \\
\hline & $(0.013)$ & $(0.068)$ & $(0.026)$ & $(0.003)$ & $(0.000)$ & $(0.000)$ & $(0.000)$ & $(0.000)$ & $(0.376)$ & $(0.000)$ & $(0.769)$ & $(0.001)$ \\
\hline \multirow{2}{*}{$\begin{array}{l}\text { E) Unit root in } \\
\text { forward rates }\end{array}$} & 100.2 & 98.7 & 93.4 & 89.1 & 86.9 & 100.6 & 112.4 & 120.2 & 133.7 & 67.8 & 356.5 & 59.5 \\
\hline & $(0.265)$ & $(0.068)$ & $(0.015)$ & $(0.004)$ & $(0.000)$ & $(0.000)$ & $(0.000)$ & $(0.000)$ & $(0.072)$ & $(0.000)$ & $(0.744)$ & $(0.001)$ \\
\hline \multirow{2}{*}{ VAR in levels } & 101.3 & 101.6 & 97.4 & 91.7 & 84.7 & 84.1 & 81.8 & 78.0 & 84.7 & 74.3 & 279.1 & 64.9 \\
\hline & $(0.414)$ & $(0.280)$ & $(0.052)$ & $(0.007)$ & $(0.000)$ & $(0.000)$ & $(0.000)$ & $(0.000)$ & $(0.002)$ & $(0.004)$ & $(0.796)$ & $(0.001)$ \\
\hline
\end{tabular}




\begin{tabular}{|c|c|c|c|c|c|c|c|c|c|c|c|c|}
\hline & $1 \mathrm{M}$ & $3 \mathrm{M}$ & $6 \mathrm{M}$ & $12 \mathrm{M}$ & $24 \mathrm{M}$ & $36 \mathrm{M}$ & $48 \mathrm{M}$ & $60 \mathrm{M}$ & $\begin{array}{c}1993- \\
99\end{array}$ & $\begin{array}{c}2000- \\
06\end{array}$ & $\begin{array}{c}2007- \\
10 \\
\end{array}$ & $\begin{array}{c}2011- \\
20 \\
\end{array}$ \\
\hline \multirow{2}{*}{ A) Baseline } & 100.5 & 101.5 & 103.5 & 105.1 & 99.4 & 95.3 & 92.5 & 90.7 & 115.5 & 72.5 & 170.1 & 78.5 \\
\hline & $(0.317)$ & $(0.331)$ & $(0.400)$ & $(0.367)$ & $(0.107)$ & $(0.038)$ & $(0.015)$ & $(0.012)$ & $(0.958)$ & $(0.001)$ & $(0.988)$ & $(0.005)$ \\
\hline \multirow{2}{*}{$\begin{array}{c}\text { B) Estimation } \\
\text { sample starts in } \\
1985 \\
\end{array}$} & 100.6 & 101.9 & 104.9 & 109.0 & 106.4 & 105.2 & 104.3 & 104.0 & 160.4 & 70.9 & 178.1 & 84.4 \\
\hline & $(0.497)$ & $(0.491)$ & $(0.645)$ & $(0.711)$ & $(0.412)$ & $(0.325)$ & $(0.262)$ & $(0.264)$ & $(1.000)$ & $(0.001)$ & $(0.993)$ & $(0.008)$ \\
\hline \multirow{2}{*}{ C) Panel } & 99.8 & 99.8 & 99.6 & 99.6 & 96.7 & 92.9 & 88.9 & 84.7 & 117.4 & 64.6 & 189.1 & 71.1 \\
\hline & $(0.152)$ & $(0.167)$ & $(0.158)$ & $(0.115)$ & $(0.024)$ & $(0.010)$ & $(0.004)$ & $(0.002)$ & $(0.955)$ & $(0.001)$ & $(0.976)$ & $(0.003)$ \\
\hline \multirow{2}{*}{$\begin{array}{l}\text { D) Alternative } \\
\text { model }\end{array}$} & 100.9 & 100.7 & 102.9 & 105.3 & 101.3 & 98.4 & 96.5 & 95.4 & 114.9 & 78.6 & 166.5 & 83.0 \\
\hline & $(0.457)$ & $(0.334)$ & $(0.511)$ & $(0.544)$ & $(0.212)$ & $(0.093)$ & $(0.043)$ & $(0.044)$ & $(0.967)$ & $(0.001)$ & $(0.990)$ & $(0.008)$ \\
\hline \multirow{2}{*}{$\begin{array}{l}\text { E) Unit root in } \\
\text { forward rates }\end{array}$} & 100.5 & 101.7 & 104.9 & 110.0 & 110.9 & 111.8 & 111.4 & 110.9 & 184.5 & 56.1 & 250.8 & 78.0 \\
\hline & $(0.317)$ & $(0.334)$ & $(0.419)$ & $(0.396)$ & $(0.138)$ & $(0.062)$ & $(0.021)$ & $(0.016)$ & $(0.905)$ & $(0.001)$ & $(0.987)$ & $(0.007)$ \\
\hline \multirow{2}{*}{ F) VAR in levels } & 101.2 & 103.1 & 105.9 & 108.2 & 101.1 & 95.6 & 92.2 & 89.1 & 107.9 & 77.1 & 168.7 & 79.1 \\
\hline & $(0.332)$ & $(0.352)$ & $(0.440)$ & $(0.476)$ & $(0.156)$ & $(0.039)$ & $(0.011)$ & $(0.006)$ & $(0.545)$ & $(0.001)$ & $(0.988)$ & $(0.006)$ \\
\hline
\end{tabular}

AUD/USD

Full sample, different forecast horizons

\begin{tabular}{|c|c|c|c|c|c|c|c|c|c|c|c|c|}
\hline & & \\
\hline & $1 \mathrm{M}$ & $3 \mathrm{M}$ & $6 \mathrm{M}$ & $12 \mathrm{M}$ & $24 \mathrm{M}$ & $36 \mathrm{M}$ & $48 \mathrm{M}$ & $60 \mathrm{M}$ & $\begin{array}{c}1993- \\
99\end{array}$ & $\begin{array}{c}2000- \\
06\end{array}$ & $\begin{array}{c}2007- \\
10\end{array}$ & $\begin{array}{c}2011- \\
20\end{array}$ \\
\hline \multirow{2}{*}{ A) Baseline } & 99.0 & 97.3 & 94.9 & 91.2 & 86.5 & 85.1 & 83.4 & 84.1 & 90.9 & 82.4 & 169.3 & 71.1 \\
\hline & $(0.024)$ & $(0.024)$ & $(0.014)$ & $(0.003)$ & $(0.000)$ & $(0.001)$ & $(0.001)$ & $(0.001)$ & $(0.074)$ & $(0.000)$ & $(1.000)$ & $(0.002)$ \\
\hline \multirow{2}{*}{$\begin{array}{c}\text { B) Estimation } \\
\text { sample starts in } \\
1985\end{array}$} & 100.6 & 101.0 & 99.6 & 94.1 & 84.7 & 82.6 & 78.9 & 79.4 & 90.5 & 48.5 & 315.3 & 76.3 \\
\hline & $(0.030)$ & $(0.027)$ & $(0.018)$ & $(0.003)$ & $(0.000)$ & $(0.000)$ & $(0.000)$ & $(0.000)$ & $(0.018)$ & $(0.000)$ & $(1.000)$ & $(0.005)$ \\
\hline \multirow{2}{*}{ C) Panel } & 98.7 & 96.4 & 93.3 & 88.4 & 81.3 & 78.3 & 73.6 & 73.1 & 106.8 & 63.2 & 176.0 & 67.7 \\
\hline & $(0.011)$ & $(0.010)$ & $(0.006)$ & $(0.001)$ & $(0.000)$ & $(0.000)$ & $(0.000)$ & $(0.000)$ & $(0.411)$ & $(0.000)$ & $(0.999)$ & $(0.001)$ \\
\hline \multirow{2}{*}{$\begin{array}{l}\text { D) Alternative } \\
\text { model }\end{array}$} & 98.8 & 96.8 & 94.5 & 91.8 & 87.1 & 86.1 & 85.0 & 86.3 & 90.4 & 84.7 & 168.6 & 71.7 \\
\hline & $(0.080)$ & $(0.024)$ & $(0.011)$ & $(0.004)$ & $(0.000)$ & $(0.002)$ & $(0.002)$ & $(0.002)$ & $(0.066)$ & $(0.000)$ & $(1.000)$ & $(0.002)$ \\
\hline \multirow{2}{*}{$\begin{array}{l}\text { E) Unit root in } \\
\text { forward rates }\end{array}$} & 99.0 & 97.3 & 94.7 & 90.7 & 84.8 & 82.5 & 78.8 & 78.9 & 87.1 & 74.2 & 208.0 & 67.7 \\
\hline & $(0.024)$ & $(0.024)$ & $(0.015)$ & $(0.003)$ & $(0.000)$ & $(0.001)$ & $(0.001)$ & $(0.000)$ & $(0.044)$ & $(0.000)$ & $(1.000)$ & $(0.002)$ \\
\hline \multirow{2}{*}{ F) VAR in levels } & 99.4 & 98.3 & 96.6 & 95.2 & 92.8 & 93.0 & 90.0 & 87.2 & 92.1 & 101.9 & 165.6 & 70.5 \\
\hline & $(0.049)$ & $(0.042)$ & $(0.029)$ & $(0.022)$ & $(0.011)$ & $(0.034)$ & $(0.017)$ & $(0.005)$ & $(0.061)$ & $(0.543)$ & $(1.000)$ & $(0.002)$ \\
\hline \multirow[t]{2}{*}{ NZD/USD } & \multicolumn{8}{|c|}{ Full sample, different forecast horizons } & \multicolumn{4}{|c|}{$\begin{array}{c}\text { Different samples, } 36 \mathrm{M} \text { forecast } \\
\text { horizon }\end{array}$} \\
\hline & $1 \mathrm{M}$ & $3 \mathrm{M}$ & $6 \mathrm{M}$ & $12 \mathrm{M}$ & $24 \mathrm{M}$ & $36 \mathrm{M}$ & $48 \mathrm{M}$ & $60 \mathrm{M}$ & $\begin{array}{c}1993- \\
99\end{array}$ & $\begin{array}{c}2000- \\
06\end{array}$ & $\begin{array}{c}2007- \\
10\end{array}$ & $\begin{array}{c}2011- \\
20\end{array}$ \\
\hline \multirow{2}{*}{ A) Baseline } & 100.7 & 102.4 & 102.4 & 101.4 & 97.2 & 96.1 & 95.6 & 98.4 & 168.3 & 60.5 & 230.1 & 99.7 \\
\hline & $(0.126)$ & $(0.143)$ & $(0.093)$ & $(0.045)$ & $(0.009)$ & $(0.006)$ & $(0.004)$ & $(0.003)$ & $(0.577)$ & $(0.000)$ & $(0.570)$ & $(0.020)$ \\
\hline \multirow{2}{*}{$\begin{array}{c}\text { B) Estimation } \\
\text { sample starts in } \\
1985 \\
\end{array}$} & 100.7 & 102.4 & 102.4 & 101.4 & 97.2 & 96.1 & 95.6 & 98.4 & 168.3 & 60.5 & 230.1 & 99.7 \\
\hline & $(0.126)$ & $(0.143)$ & $(0.093)$ & $(0.045)$ & $(0.009)$ & $(0.006)$ & $(0.004)$ & $(0.003)$ & $(0.577)$ & $(0.000)$ & $(0.570)$ & $(0.020)$ \\
\hline \multirow{2}{*}{ C) Panel } & 99.4 & 98.6 & 96.8 & 94.1 & 89.5 & 87.4 & 86.1 & 87.5 & 118.5 & 69.8 & 180.2 & 88.2 \\
\hline & $(0.036)$ & $(0.051)$ & $(0.031)$ & $(0.015)$ & $(0.003)$ & $(0.001)$ & $(0.001)$ & $(0.001)$ & $(0.570)$ & $(0.000)$ & $(0.523)$ & $(0.009)$ \\
\hline \multirow{2}{*}{$\begin{array}{l}\text { D) Alternative } \\
\text { model }\end{array}$} & 100.4 & 100.4 & 100.6 & 100.2 & 96.9 & 96.8 & 97.2 & 99.8 & 161.1 & 67.6 & 200.5 & 95.6 \\
\hline & $(0.088)$ & $(0.075)$ & $(0.086)$ & $(0.052)$ & $(0.015)$ & $(0.012)$ & $(0.009)$ & $(0.007)$ & $(0.770)$ & $(0.000)$ & $(0.561)$ & $(0.021)$ \\
\hline \multirow{2}{*}{$\begin{array}{l}\text { E) Unit root in } \\
\text { forward rates }\end{array}$} & 100.7 & 102.8 & 103.6 & 105.0 & 105.3 & 108.3 & 111.1 & 124.9 & 231.5 & 42.2 & 363.4 & 125.3 \\
\hline & $(0.126)$ & $(0.146)$ & $(0.097)$ & $(0.048)$ & $(0.008)$ & $(0.003)$ & $(0.001)$ & $(0.000)$ & $(0.391)$ & $(0.000)$ & $(0.585)$ & $(0.020)$ \\
\hline \multirow{2}{*}{ F) VAR in levels } & 101.6 & 104.8 & 104.9 & 103.8 & 91.6 & 78.9 & 69.7 & 66.4 & 50.2 & 66.5 & 270.2 & 108.2 \\
\hline & $(0.387)$ & $(0.415)$ & $(0.222)$ & $(0.095)$ & $(0.004)$ & $(0.000)$ & $(0.000)$ & $(0.000)$ & $(0.000)$ & $(0.001)$ & $(0.583)$ & $(0.028)$ \\
\hline
\end{tabular}


Full sample, different forecast horizons

\begin{tabular}{|c|c|c|c|c|c|c|c|c|c|c|c|c|}
\hline \multirow[t]{2}{*}{ GBP/DEM } & \multicolumn{8}{|c|}{ Full sample, different forecast horizons } & \multicolumn{4}{|c|}{ horizon } \\
\hline & $1 \mathrm{M}$ & $3 \mathrm{M}$ & $6 \mathrm{M}$ & $12 \mathrm{M}$ & $24 \mathrm{M}$ & $36 \mathrm{M}$ & $48 \mathrm{M}$ & $60 \mathrm{M}$ & $\begin{array}{c}1993- \\
99\end{array}$ & $\begin{array}{c}2000- \\
06\end{array}$ & $\begin{array}{c}2007- \\
10\end{array}$ & $\begin{array}{c}2011- \\
20\end{array}$ \\
\hline \multirow{2}{*}{ A) Baseline } & 99.8 & 99.0 & 98.0 & 96.3 & 94.2 & 93.1 & 93.6 & 96.5 & 97.9 & 87.7 & 82.8 & 100.3 \\
\hline & $(0.131)$ & $(0.063)$ & $(0.032)$ & $(0.008)$ & $(0.002)$ & $(0.004)$ & $(0.008)$ & $(0.033)$ & $(0.237)$ & $(0.030)$ & $(0.000)$ & $(0.164)$ \\
\hline \multirow{2}{*}{$\begin{array}{c}\text { B) Estimation } \\
\text { sample starts in } \\
1985 \\
\end{array}$} & 100.3 & & 98.3 & 94.8 & 88.8 & 86.8 & 89.8 & 97.7 & 79.4 & 153.4 & 66.8 & 92.4 \\
\hline & $(0.151)$ & $(0.074)$ & $(0.040)$ & $(0.005)$ & $(0.000)$ & $(0.000)$ & $(0.001)$ & $(0.005)$ & $(0.002)$ & $(0.121)$ & $(0.000)$ & $(0.018)$ \\
\hline \multirow{2}{*}{ C) Panel } & 99.5 & 98.4 & 97.0 & 94.4 & 91.1 & 89.9 & 89.1 & 90.3 & 91.7 & 86.1 & 83.9 & 96.6 \\
\hline & $(0.033)$ & $(0.020)$ & $(0.009)$ & $(0.001)$ & $(0.000)$ & $(0.000)$ & $(0.000)$ & $(0.001)$ & $(0.010)$ & $(0.032)$ & $(0.000)$ & $(0.060)$ \\
\hline \multirow{2}{*}{$\begin{array}{l}\text { D) Alternative } \\
\text { model }\end{array}$} & 100.4 & 99.0 & 97.9 & 95.2 & 91.6 & 89.3 & 87.8 & 89.2 & 88.4 & 84.6 & 83.0 & 103.0 \\
\hline & $(0.203)$ & $(0.056)$ & $(0.036)$ & $(0.006)$ & $(0.000)$ & $(0.000)$ & $(0.000)$ & $(0.000)$ & $(0.000)$ & $(0.018)$ & $(0.000)$ & $(0.170)$ \\
\hline \multirow{2}{*}{$\begin{array}{l}\text { E) Unit root in } \\
\text { forward rates }\end{array}$} & 99.8 & 99.1 & 98.0 & 96.6 & 95.3 & 95.0 & 91.1 & 90.3 & 92.7 & 92.4 & 83.9 & 117.2 \\
\hline & $(0.131)$ & $(0.065)$ & $(0.034)$ & $(0.011)$ & $(0.003)$ & $(0.002)$ & $(0.000)$ & $(0.000)$ & $(0.029)$ & $(0.016)$ & $(0.000)$ & $(0.260)$ \\
\hline \multirow{2}{*}{ F) VAR in levels } & 101.3 & 101.8 & 102.0 & 99.0 & 97.7 & 102.8 & 118.0 & 136.3 & 119.3 & 96.0 & 80.3 & 101.9 \\
\hline & $(0.160)$ & $(0.107)$ & $(0.085)$ & $(0.026)$ & $(0.022)$ & $(0.070)$ & $(0.452)$ & $(0.775)$ & $(0.335)$ & $(0.051)$ & $(0.000)$ & $(0.330)$ \\
\hline
\end{tabular}

Different samples, 36M forecast horizon

Different samples, 36M forecast horizon
Full sample, different forecast horizons

\begin{tabular}{|c|c|c|c|c|c|c|c|c|c|c|c|c|}
\hline & & \multicolumn{4}{|c|}{ 11012000 } \\
\hline & $1 \mathrm{M}$ & $3 \mathrm{M}$ & $6 \mathrm{M}$ & $12 \mathrm{M}$ & $24 \mathrm{M}$ & $36 \mathrm{M}$ & $48 \mathrm{M}$ & $60 \mathrm{M}$ & $\begin{array}{c}1993- \\
99\end{array}$ & $\begin{array}{c}2000- \\
06\end{array}$ & $\begin{array}{c}2007- \\
10\end{array}$ & $\begin{array}{c}2011- \\
20\end{array}$ \\
\hline \multirow{2}{*}{ A) Baseline } & 100.0 & 100.1 & 99.9 & 99.4 & 98.6 & 96.5 & 94.3 & 93.9 & 112.3 & 103.8 & 84.7 & 81.0 \\
\hline & $(0.358)$ & $(0.426)$ & $(0.339)$ & $(0.261)$ & $(0.167)$ & $(0.061)$ & $(0.024)$ & $(0.032)$ & $(0.890)$ & $(0.515)$ & $(0.003)$ & $(0.000)$ \\
\hline \multirow{2}{*}{$\begin{array}{c}\text { B) Estimation } \\
\text { sample starts in } \\
1985\end{array}$} & 100.4 & 101.5 & 101.2 & 100.5 & 99.6 & 97.1 & 95.4 & 96.2 & 118.6 & 109.6 & 81.0 & 73.6 \\
\hline & $(0.523)$ & $(0.610)$ & $(0.433)$ & $(0.292)$ & $(0.164)$ & $(0.055)$ & $(0.027)$ & $(0.044)$ & $(0.944)$ & $(0.641)$ & $(0.009)$ & $(0.000)$ \\
\hline \multirow{2}{*}{ C) Panel } & 99.6 & 98.9 & 97.7 & 94.9 & 89.4 & 84.7 & 79.9 & 75.5 & 93.5 & 83.7 & 84.4 & 78.1 \\
\hline & $(0.097)$ & $(0.094)$ & $(0.056)$ & $(0.010)$ & $(0.000)$ & $(0.000)$ & $(0.000)$ & $(0.000)$ & $(0.016)$ & $(0.010)$ & $(0.001)$ & $(0.000)$ \\
\hline \multirow{2}{*}{$\begin{array}{l}\text { D) Alternative } \\
\text { model }\end{array}$} & 100.6 & 99.9 & 100.0 & 99.1 & 98.3 & 96.4 & 94.4 & 93.9 & 110.3 & 104.9 & 85.1 & 81.4 \\
\hline & $(0.516)$ & $(0.301)$ & $(0.341)$ & $(0.216)$ & $(0.145)$ & $(0.059)$ & $(0.026)$ & $(0.034)$ & $(0.858)$ & $(0.577)$ & $(0.004)$ & $(0.000)$ \\
\hline \multirow{2}{*}{$\begin{array}{l}\text { E) Unit root in } \\
\text { forward rates }\end{array}$} & 100.0 & 100.1 & 99.9 & 99.4 & 98.5 & 95.8 & 92.7 & 91.4 & 115.2 & 105.6 & 81.0 & 76.4 \\
\hline & $(0.358)$ & $(0.425)$ & $(0.337)$ & $(0.256)$ & $(0.160)$ & $(0.047)$ & $(0.013)$ & $(0.012)$ & $(0.890)$ & $(0.564)$ & $(0.004)$ & $(0.000)$ \\
\hline \multirow{2}{*}{ F) VAR in levels } & 101.4 & 104.9 & 108.1 & 112.2 & 110.0 & 102.3 & 94.8 & 90.4 & 134.6 & 104.1 & 81.1 & 83.5 \\
\hline & $(0.800)$ & $(0.916)$ & $(0.920)$ & $(0.918)$ & $(0.803)$ & $(0.316)$ & $(0.033)$ & $(0.009)$ & $(0.986)$ & $(0.508)$ & $(0.003)$ & $(0.004)$ \\
\hline
\end{tabular}

CHF/DEM

Full sample, different forecast horizons

\begin{tabular}{|c|c|c|c|c|c|c|c|c|c|c|c|c|}
\hline & & & & & & & & & \\
\hline & $1 \mathrm{M}$ & $3 \mathrm{M}$ & $6 \mathrm{M}$ & $12 \mathrm{M}$ & $24 \mathrm{M}$ & $36 \mathrm{M}$ & $48 \mathrm{M}$ & $60 \mathrm{M}$ & $\begin{array}{c}1993- \\
99 \\
\end{array}$ & $\begin{array}{c}2000- \\
06 \\
\end{array}$ & $\begin{array}{c}2007- \\
10\end{array}$ & $\begin{array}{c}2011- \\
20\end{array}$ \\
\hline \multirow{2}{*}{ A) Baseline } & 101.1 & 103.8 & 106.0 & 107.8 & 105.2 & 101.9 & 98.2 & 95.5 & 51.1 & 85.6 & 80.5 & 115.5 \\
\hline & $(0.702)$ & $(0.749)$ & $(0.739)$ & $(0.717)$ & $(0.502)$ & $(0.262)$ & $(0.100)$ & $(0.034)$ & $(0.003)$ & $(0.011)$ & $(0.012)$ & $(0.999)$ \\
\hline \multirow{2}{*}{$\begin{array}{c}\text { B) Estimation } \\
\text { sample starts in } \\
1985\end{array}$} & 101.8 & 105.9 & 108.7 & 111.4 & 109.8 & 108.6 & 106.9 & 106.0 & 59.5 & 114.9 & 82.4 & 120.4 \\
\hline & $(0.633)$ & $(0.707)$ & $(0.676)$ & $(0.686)$ & $(0.586)$ & $(0.514)$ & $(0.373)$ & $(0.407)$ & $(0.004)$ & $(0.366)$ & $(0.006)$ & $(0.999)$ \\
\hline \multirow{2}{*}{ C) Panel } & 100.9 & 103.2 & 105.9 & 108.8 & 108.3 & 108.4 & 109.5 & 106.1 & 76.8 & 85.3 & 85.2 & 121.1 \\
\hline & $(0.580)$ & $(0.644)$ & $(0.643)$ & $(0.622)$ & $(0.454)$ & $(0.459)$ & $(0.622)$ & $(0.622)$ & $(0.004)$ & $(0.001)$ & $(0.020)$ & $(0.845)$ \\
\hline \multirow{2}{*}{$\begin{array}{l}\text { D) Alternative } \\
\text { model }\end{array}$} & 102.3 & 103.3 & 105.3 & 106.6 & 104.8 & 101.1 & 95.0 & 91.4 & 59.1 & 80.3 & 79.8 & 114.3 \\
\hline & $(0.697)$ & $(0.729)$ & $(0.772)$ & $(0.718)$ & $(0.488)$ & $(0.196)$ & $(0.014)$ & $(0.001)$ & $(0.003)$ & $(0.001)$ & $(0.015)$ & $(0.951)$ \\
\hline \multirow{2}{*}{$\begin{array}{l}\text { E) Unit root in } \\
\text { forward rates }\end{array}$} & 101.1 & 104.0 & 107.2 & 112.5 & 116.8 & 120.1 & 126.3 & 137.7 & 73.6 & 160.2 & 65.7 & 134.2 \\
\hline & $(0.702)$ & $(0.740)$ & $(0.716)$ & $(0.688)$ & $(0.483)$ & $(0.311)$ & $(0.264)$ & $(0.419)$ & $(0.002)$ & $(0.224)$ & $(0.007)$ & $(1.000)$ \\
\hline \multirow{2}{*}{ F) VAR in levels } & 101.6 & 104.7 & 108.2 & 115.5 & 120.8 & 119.2 & 118.9 & 119.7 & 53.0 & 142.1 & 81.0 & 133.9 \\
\hline & $(0.635)$ & $(0.606)$ & $(0.605)$ & $(0.747)$ & $(0.810)$ & $(0.702)$ & $(0.668)$ & $(0.778)$ & $(0.004)$ & $(0.300)$ & $(0.003)$ & (0.999) \\
\hline
\end{tabular}

Notes: The results of combined forecasts are reported, whereby three forecasts are combined with equal weights horizon

Different samples, 36M forecast 
from the three models using alternative maturity theoretical forward rates, 3 year, 5 year or 10 years (expect for New Zealand and Sweden, for which the 2-year maturity rate is used instead of the 3-year maturity rate). Blocks A, B, C and E use the model defined in equation (13), block D is based on equation (19), while in block F is based on equation (20). The sample period includes monthly data from January 1979 to February 2020 (with a few data-driven exceptions). Using the recursive estimation window, out-of-sample evaluation of forecasts was performed in the 1990-2020 period except in the last four data columns, for which the evaluation period is indicated in the heading. $p$ values are reported in parentheses of testing the null hypothesis that the model MSFE is the same as that of the random walk against the one-sided alternative hypothesis that the model is better, based on the test of Clark and West (2006, 2007). 
Table 6: Recursive vs rolling estimation, out-of-sample forecast evaluation, DEM/USD rate, mean squared forecast error $($ random walk $=100)$

Forecast horizon

\begin{tabular}{|c|c|c|c|c|c|c|c|c|c|}
\hline \multirow[b]{2}{*}{$\begin{array}{l}\text { estimation } \\
\text { method }\end{array}$} & \multirow[b]{2}{*}{$\begin{array}{l}\text { rolling } \\
\text { estimation } \\
\text { months }\end{array}$} & \\
\hline & & $1 \mathrm{M}$ & $3 \mathrm{M}$ & $6 \mathrm{M}$ & $12 \mathrm{M}$ & $24 \mathrm{M}$ & $36 \mathrm{M}$ & $48 \mathrm{M}$ & $60 \mathrm{M}$ \\
\hline \multirow{20}{*}{ rolling } & \multirow[t]{2}{*}{60} & 101.9 & 104.9 & 102.7 & 98.7 & 89.3 & 85.1 & 98.9 & 97.2 \\
\hline & & $(0.086)$ & $(0.124)$ & $(0.046)$ & $(0.015)$ & $(0.000)$ & $(0.000)$ & $(0.006)$ & $(0.004)$ \\
\hline & \multirow[t]{2}{*}{80} & 101.3 & 103.3 & 101.5 & 95.7 & 101.8 & 112.4 & 119.5 & 118.7 \\
\hline & & $(0.063)$ & $(0.075)$ & $(0.028)$ & $(0.003)$ & $(0.023)$ & $(0.122)$ & $(0.213)$ & $(0.121)$ \\
\hline & \multirow[t]{2}{*}{100} & 102.1 & 105.5 & 105.2 & 101.3 & 106.5 & 115.2 & 120.5 & 116.7 \\
\hline & & $(0.191)$ & $(0.239)$ & $(0.122)$ & $(0.027)$ & $(0.070)$ & $(0.186)$ & $(0.261)$ & $(0.124)$ \\
\hline & \multirow[t]{2}{*}{120} & 101.6 & 104.5 & 105.2 & 102.7 & 102.9 & 98.8 & 96.3 & 93.9 \\
\hline & & $(0.158)$ & $(0.206)$ & $(0.131)$ & $(0.046)$ & $(0.064)$ & $(0.038)$ & $(0.023)$ & $(0.010)$ \\
\hline & \multirow[t]{2}{*}{140} & 101.6 & 104.1 & 105.2 & 102.4 & 94.3 & 86.3 & 84.1 & 78.1 \\
\hline & & $(0.250)$ & $(0.268)$ & $(0.185)$ & $(0.053)$ & $(0.016)$ & $(0.014)$ & $(0.009)$ & $(0.001)$ \\
\hline & \multirow[t]{2}{*}{160} & 101.0 & 102.7 & 104.1 & 101.6 & 94.2 & 83.0 & 78.4 & 71.0 \\
\hline & & $(0.194)$ & $(0.196)$ & $(0.161)$ & $(0.053)$ & $(0.031)$ & $(0.014)$ & $(0.004)$ & $(0.001)$ \\
\hline & \multirow[t]{2}{*}{180} & 101.7 & 104.0 & 106.1 & 102.8 & 88.2 & 71.9 & 65.1 & 57.7 \\
\hline & & $(0.232)$ & $(0.184)$ & $(0.130)$ & $(0.029)$ & $(0.009)$ & $(0.003)$ & $(0.000)$ & $(0.000)$ \\
\hline & \multirow[t]{2}{*}{200} & 99.8 & 99.0 & 96.9 & 88.2 & 73.0 & 59.3 & 54.7 & 48.7 \\
\hline & & $(0.045)$ & $(0.037)$ & $(0.023)$ & $(0.008)$ & $(0.004)$ & $(0.001)$ & $(0.000)$ & $(0.000)$ \\
\hline & \multirow[t]{2}{*}{220} & 98.9 & 97.4 & 94.5 & 85.5 & 71.5 & 59.9 & 53.8 & 48.0 \\
\hline & & $(0.025)$ & $(0.026)$ & $(0.016)$ & $(0.003)$ & $(0.001)$ & $(0.000)$ & $(0.000)$ & $(0.000)$ \\
\hline & \multirow[t]{2}{*}{240} & 98.9 & 97.3 & 94.4 & 86.6 & 74.9 & 63.7 & 57.0 & 51.7 \\
\hline & & $(0.025)$ & $(0.024)$ & $(0.014)$ & $(0.002)$ & $(0.001)$ & $(0.000)$ & $(0.000)$ & $(0.000)$ \\
\hline \multirow{2}{*}{ recursive } & & 99.2 & 98.2 & 95.9 & 88.8 & 77.5 & 67.5 & 62.5 & 57.0 \\
\hline & & $(0.035)$ & $(0.034)$ & $(0.021)$ & $(0.003)$ & $(0.001)$ & $(0.000)$ & $(0.000)$ & $(0.000)$ \\
\hline
\end{tabular}

Notes: The results of combined forecasts are reported, whereby three forecasts are combined with equal weights from three models using alternative maturity theoretical forward rates, 3 years, 5 years and 10 years (expect for New Zealand and Sweden, for which the 2-year maturity rate is used instead of the 3-year maturity rate). The model is defined in equation (13). The sample period includes monthly data from January 1979 to February 2020. Using either the recursive or rolling estimation windows, out-of-sample evaluation of forecasts was performed in the 1990-2020 period. p values are reported in parentheses of testing the null hypothesis that the model MSFE is the same as that of the random walk against the one-sided alternative hypothesis that the model is better, based on the test of Clark and West $(2006,2007)$. See the results for other currency pairs in Table A4 of the appendices. 
Table 7: Different ways of combining end-of-month and monthly average data, out-of-sample forecast evaluation, mean squared forecast error (random walk =100), GBP/USD rate

\begin{tabular}{|c|c|c|c|c|c|c|c|c|}
\hline \multirow[b]{2}{*}{$\begin{array}{c}\text { Data conversion } \\
\text { option }\end{array}$} & \multicolumn{8}{|c|}{ Forecast horizon } \\
\hline & $1 \mathrm{M}$ & $3 \mathrm{M}$ & $6 \mathrm{M}$ & $12 \mathrm{M}$ & $24 \mathrm{M}$ & $36 \mathrm{M}$ & $48 \mathrm{M}$ & $60 \mathrm{M}$ \\
\hline 1) & $\begin{array}{r}99.5 \\
(0.030) \\
\end{array}$ & $\begin{array}{r}97.4 \\
(0.011) \\
\end{array}$ & $\begin{array}{r}93.2 \\
(0.005) \\
\end{array}$ & $\begin{array}{r}90.9 \\
(0.009) \\
\end{array}$ & $\begin{array}{r}80.2 \\
(0.001) \\
\end{array}$ & $\begin{array}{r}75.4 \\
(0.000) \\
\end{array}$ & $\begin{array}{r}70.1 \\
(0.000) \\
\end{array}$ & $\begin{array}{r}71.1 \\
(0.000)\end{array}$ \\
\hline 2) & $\begin{array}{r}99.7 \\
(0.043) \\
\end{array}$ & $\begin{array}{r}97.3 \\
(0.009) \\
\end{array}$ & $\begin{array}{r}93.1 \\
(0.004) \\
\end{array}$ & $\begin{array}{r}90.9 \\
(0.009) \\
\end{array}$ & $\begin{array}{r}80.3 \\
(0.001)\end{array}$ & $\begin{array}{r}76.9 \\
(0.000) \\
\end{array}$ & $\begin{array}{r}71.7 \\
(0.000)\end{array}$ & $\begin{array}{r}72.8 \\
(0.000) \\
\end{array}$ \\
\hline 3) & $\begin{array}{r}99.5 \\
(0.033) \\
\end{array}$ & $\begin{array}{r}97.5 \\
(0.010) \\
\end{array}$ & $\begin{array}{r}93.6 \\
(0.006)\end{array}$ & $\begin{array}{r}91.2 \\
(0.009) \\
\end{array}$ & $\begin{array}{r}80.4 \\
(0.001) \\
\end{array}$ & $\begin{array}{r}76.2 \\
(0.000)\end{array}$ & $\begin{array}{r}70.8 \\
(0.000) \\
\end{array}$ & $\begin{array}{r}71.7 \\
(0.000) \\
\end{array}$ \\
\hline 4) & $\begin{array}{r}99.6 \\
(0.040) \\
\end{array}$ & $\begin{array}{r}97.3 \\
(0.010) \\
\end{array}$ & $\begin{array}{r}92.8 \\
(0.004) \\
\end{array}$ & $\begin{array}{r}90.5 \\
(0.008)\end{array}$ & $\begin{array}{r}80.0 \\
(0.001) \\
\end{array}$ & $\begin{array}{r}75.5 \\
(0.000) \\
\end{array}$ & $\begin{array}{r}70.7 \\
(0.000) \\
\end{array}$ & $\begin{array}{r}71.4 \\
(0.000)\end{array}$ \\
\hline 5) & $\begin{array}{r}99.4 \\
(0.040)\end{array}$ & $\begin{array}{r}97.3 \\
(0.015) \\
\end{array}$ & $\begin{array}{r}93.5 \\
(0.007)\end{array}$ & $\begin{array}{r}90.7 \\
(0.010) \\
\end{array}$ & $\begin{array}{r}80.2 \\
(0.001) \\
\end{array}$ & $\begin{array}{r}75.4 \\
(0.000) \\
\end{array}$ & $\begin{array}{r}71.0 \\
(0.000) \\
\end{array}$ & $\begin{array}{r}72.0 \\
(0.000)\end{array}$ \\
\hline 6) & $\begin{array}{r}99.6 \\
(0.052)\end{array}$ & $\begin{array}{r}97.3 \\
(0.015) \\
\end{array}$ & $\begin{array}{r}93.3 \\
(0.006) \\
\end{array}$ & $\begin{array}{r}90.4 \\
(0.009)\end{array}$ & $\begin{array}{r}80.4 \\
(0.001)\end{array}$ & $\begin{array}{r}75.7 \\
(0.000) \\
\end{array}$ & $\begin{array}{r}71.5 \\
(0.000)\end{array}$ & $\begin{array}{r}72.2 \\
(0.000) \\
\end{array}$ \\
\hline 7) & $\begin{array}{r}99.8 \\
(0.077) \\
\end{array}$ & $\begin{array}{r}97.5 \\
(0.016) \\
\end{array}$ & $\begin{array}{r}93.9 \\
(0.009) \\
\end{array}$ & $\begin{array}{r}91.0 \\
(0.011) \\
\end{array}$ & $\begin{array}{r}80.4 \\
(0.001) \\
\end{array}$ & $\begin{array}{r}76.1 \\
(0.000) \\
\end{array}$ & $\begin{array}{r}71.5 \\
(0.000) \\
\end{array}$ & $\begin{array}{r}72.4 \\
(0.000) \\
\end{array}$ \\
\hline 8) & $\begin{array}{r}99.9 \\
(0.097) \\
\end{array}$ & $\begin{array}{r}97.4 \\
(0.016) \\
\end{array}$ & $\begin{array}{r}93.6 \\
(0.007) \\
\end{array}$ & $\begin{array}{r}90.7 \\
(0.010) \\
\end{array}$ & $\begin{array}{r}80.4 \\
(0.001) \\
\end{array}$ & $\begin{array}{r}76.6 \\
(0.000) \\
\end{array}$ & $\begin{array}{r}72.0 \\
(0.000) \\
\end{array}$ & $\begin{array}{r}73.0 \\
(0.000) \\
\end{array}$ \\
\hline $\begin{array}{l}\text { range: point est. } \\
\text { range: p value }\end{array}$ & $\begin{array}{r}0.5 \\
(0.067) \\
\end{array}$ & $\begin{array}{r}0.2 \\
(0.006) \\
\end{array}$ & $\begin{array}{r}1.1 \\
(0.005) \\
\end{array}$ & $\begin{array}{r}0.7 \\
(0.003) \\
\end{array}$ & $\begin{array}{r}0.5 \\
(0.000) \\
\end{array}$ & $\begin{array}{r}1.5 \\
(0.000) \\
\end{array}$ & $\begin{array}{r}1.9 \\
(0.000) \\
\end{array}$ & $\begin{array}{r}1.9 \\
(0.000) \\
\end{array}$ \\
\hline
\end{tabular}

Notes: The results of combined forecasts are reported, whereby three forecasts are combined with equal weights from three models using alternative maturity theoretical forward rates, 3 years, 5 years and 10 years. The model is defined in equation (13). The sample period includes monthly data from January 1979 to February 2020.

Using the recursive estimation technique, out-of-sample evaluation of forecasts was performed in the 19902020 period. $p$ values are reported in parentheses of testing the null hypothesis that the model MSFE is the same as that of the random walk against the one-sided alternative hypothesis that the model is better, based on the test of Clark and West $(2006,2007)$. See the main text for the definitions of the eight different ways of combining end-of-month and monthly average data. 


\section{Appendices}

\section{Data sources}

\section{US dollar exchange rates:}

https://www.federalreserve.gov/datadownload/Choose.aspx?rel=H10 (daily data for our full sample period - we use end-of-month data)

\section{German mark/euro conversion rate:}

https://www.ecb.europa.eu/euro/exchange/de/html/index.en.html

German mark rates against the Japanese yen, British pound sterling and Swiss franc: calculated from US dollar exchange rates

\section{Long maturity interest rates:}

United States: https://www.federalreserve.gov/datadownload/Choose.aspx?rel=H15 (zero coupon daily data for our full sample period - we use end-of-month data)

Germany: https://www.bundesbank.de/en/statistics/money-and-capital-markets/interest-rates-andyields (zero coupon end of month data till July 1997, daily data since then - we use end-of-month data)

Japan: http://www.mof.go.jp/english/jgbs/reference/interest_rate/index.htm (daily data for our full sample period of 3-year and 5-year yields and starting in July 1986 for the 10-year yield - we use end-of-month data; for the January 1979 - June 1985 period we use 10-year government bond yield from the from the IMF International Financial Statistics, which is monthly average)

United Kingdom: https://www.bankofengland.co.uk/statistics/yield-curves (zero coupon daily data for our full sample period - we use end-of-month data)

Switzerland: https://data.snb.ch/en/topics/ziredev\#!/cube/rendoblid (zero coupon daily data available from 1988 - we use end-of-month data; 1983-1987 end-of-month bond yield data is from DataStream for the 3-year and 5-year maturities, and from the IMF International Financial Statistics for the monthly average 10-year interest rate; these earlier values were linked to more recent Swiss National Bank (SNB) data by adjusted the earlier data with the average difference to the SNB data in the first overlapping year) 
Canada: https://www.bankofcanada.ca/rates/interest-rates/bond-yield-curves/ (zero coupon daily data available from 1986 - we use end-of-month data; earlier values for monthly average government bond yields are also from the Bank of Canada; the earlier values were linked to more recent zero coupon yields by adjusted the earlier data with the average difference in the first overlapping year)

Australia: http://www.rba.gov.au/statistics/tables/xls/f17hist.xls (zero coupon daily data available from July 1992 - we use end-of-month data; earlier values for 10-year and 5-year monthly average government bond yields are also from the Reserve Bank of Australia, while the 3-year monthly average yield is from the IMF International Financial Statistics; the earlier values were linked to more recent zero coupon yields by adjusted the earlier data with the average difference in the first overlapping year)

New Zealand: https://www.rbnz.govt.nz/statistics/b2 (government bond yield daily data available from March 1985 - we use end-of-month data)

Norway: https://www.norges-bank.no/en/topics/Statistics/Interest-rates/ (government bond yield weekly data available from January 1985 for the 10-year maturity, from March 1985 for the 5-year maturity, and from March 1987 for the 3-year maturity, while daily data available from January 1990 for all three maturities - we use end-of-month data; monthly average data for earlier periods from https://www.norges-bank.no/en/topics/Statistics/Historical-monetary-statistics/Bond-markets-and-

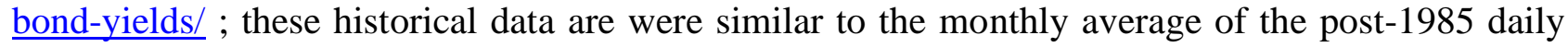
data)

Sweden: $\quad$ http://www.riksbank.se/en/Interest-and-exchange-rates/search-interest-rates-exchange-

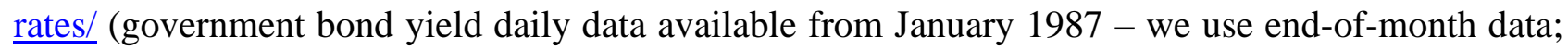
monthly average 10-year yield from the IMF International Financial Statistics is used for 1979-1986) 


\section{Unit root tests}

We use eight unit root tests to test the null hypothesis of unit root in spot and forward exchange rates. We use the standard tests for unit root of Dickey and Fuller (1979) and Phillips and Perron (1988) and six other unit root tests. Elliott et al. (1996) proposed a family of test statistics that are invariant to the trend parameters and suggested two particular tests: a modified version of the Dickey-Fuller ttest, which is based on a local GLS detrending, and another feasible point optimal test, both having substantially improved power when an unknown mean or trend is present. $\mathrm{Ng}$ and Perron (2001) exploited the findings of Elliott et al. (1996) and applied the idea of GLS detrending to modify existing tests and showed non-negligible size and power gains can be made when used in conjunction with an autoregressive spectral density estimator at frequency zero. They suggested modifications of three test statistics studied by Perron and $\mathrm{Ng}$ (1996) and the feasible point optimal test statistics of Elliott et al. (1996).

Table A1 shows the results. Our general finding is that test statistics decline with an increase in maturity of the forward rate, suggesting lower persistence for longer maturity forward rates. There are three currency pairs for which all tests suggest the 10-year maturity forward rate is stationary while the spot exchange rate is non-stationary: the three bilateral combinations of the US dollar, German mark and British pound sterling, which together account for almost 40 percent of global foreign exchange market turnover. For the Canadian dollar/US dollar, the Swiss Franc/US dollar and the Swiss Franc/German mark rates, all but two tests conclude stationarity of the long maturity forward rate. Few tests lead to this conclusion for the Australian dollar/US dollar rate and the Swedish krona/US dollar rate. For the US dollar Japanese yen, New Zealand dollar and Norwegian krona, as well as the German mark against the Japanese yen, all tests suggest the long-maturity forward rate has a unit root.

\section{References}

Dickey, D.A. and Fuller, W.A. (1979) Distribution of the Estimators for Autoregressive Time Series with a Unit Root, Journal of the American Statistical Association, vol 74, pp. 427-431

Elliott, G., Rothenberg, T.J. and Stock, J.H. (1996) Efficient Tests for an Autoregressive Unit Root, Econometrica, vol 64, pp. 813-836.

Ng, S. and Perron, P. (2001) Lag Length Selection and the Construction of Unit Root Tests with Good 
Size and Power, Econometrica, vol 69, pp. 1519-1554

Perron, P. and Ng, S. (1996) Useful Modifications to some Unit Root Tests with Dependent Errors and their Local Asymptotic Properties, Review of Economic Studies, vol 63, pp. 435-463

Phillips, P.C.B. and Perron, P. (1988) Testing for a Unit Root in Time Series Regression, Biometrika, vol 75, pp. 335-346

Table A1: Unit root tests for the logarithm of spot and theoretical forward exchange rates

\begin{tabular}{|c|c|c|c|c|c|c|c|}
\hline \multicolumn{8}{|c|}{ DEM/USD, 1979-2020 } \\
\hline & Spot & $\mathrm{F} 1 \mathrm{M}$ & F3M & $\mathrm{F} 12 \mathrm{M}$ & F3Y & F5Y & F10Y \\
\hline $\mathrm{ADF}$ & -1.78 & -1.79 & -1.79 & -1.82 & -1.99 & -2.22 & $-2.87 *$ \\
\hline PP & -1.93 & -1.95 & -1.96 & -2.01 & -2.15 & -2.30 & $-2.82 *$ \\
\hline DFGLS & $-1.69 *$ & $-1.71 *$ & $-1.73^{*}$ & $-1.81 *$ & $-1.99 * *$ & $-2.22 * *$ & $-2.87 * * *$ \\
\hline ERS & $4.33 *$ & $4.26 *$ & $4.13 *$ & $3.75^{*}$ & $3.13 * *$ & $2.52 * *$ & $1.55^{* * *}$ \\
\hline NP MZa & $-5.71^{*}$ & $-5.80 *$ & $-5.97 *$ & $-6.52 *$ & $-7.81 *$ & $-9.68 * *$ & $-16.06 * * *$ \\
\hline NP MZt & $-1.69 *$ & $-1.70 *$ & $-1.72 *$ & $-1.8^{*}$ & $-1.98 *$ & $-2.20 * *$ & $-2.83 * * *$ \\
\hline NP MSB & 0.30 & 0.29 & 0.29 & 0.28 & $0.25^{*}$ & $0.23 * *$ & $0.18 * *$ \\
\hline NP MPT & $4.30 *$ & $4.24 *$ & $4.11 *$ & $3.76^{*}$ & $3.14 * *$ & $2.53 * *$ & $1.55 * * *$ \\
\hline \multicolumn{8}{|c|}{ GBP/USD, 1979-2020 } \\
\hline & Spot & $\mathrm{F} 1 \mathrm{M}$ & $\mathrm{F} 3 \mathrm{M}$ & $\mathrm{F} 12 \mathrm{M}$ & F3Y & F5Y & $\mathrm{F} 10 \mathrm{Y}$ \\
\hline $\mathrm{ADF}$ & -1.78 & -1.79 & -1.79 & -1.82 & -1.99 & -2.22 & $-2.87 *$ \\
\hline $\mathrm{PP}$ & -1.93 & -1.95 & -1.96 & -2.01 & -2.15 & -2.30 & $-2.82 *$ \\
\hline DFGLS & $-1.69 *$ & $-1.71 *$ & $-1.73^{*}$ & $-1.81^{*}$ & $-1.99 * *$ & $-2.22 * *$ & $-2.87 * * *$ \\
\hline ERS & $4.33^{*}$ & $4.26^{*}$ & $4.13 *$ & $3.75^{*}$ & $3.13^{* *}$ & $2.52 * *$ & $1.55 * * *$ \\
\hline $\mathrm{NP} \mathrm{MZa}$ & $-5.71 *$ & $-5.80 *$ & $-5.97 *$ & $-6.52 *$ & $-7.81 *$ & $-9.68 * *$ & $-16.06^{* * *}$ \\
\hline NP MZt & $-1.69 *$ & $-1.7 *$ & $-1.72^{*}$ & $-1.80 *$ & $-1.98 *$ & $-2.2 * *$ & $-2.83 * * *$ \\
\hline NP MSB & 0.30 & 0.29 & 0.29 & 0.28 & $0.25^{*}$ & $0.23 * *$ & $0.18 * *$ \\
\hline NP MPT & $4.30 *$ & $4.24 *$ & $4.11 *$ & $3.76 *$ & $3.14 * *$ & $2.53 * *$ & $1.55 * * *$ \\
\hline
\end{tabular}


JPY/USD, 1979-2020 for all but F12M, for which 1980-2020

\begin{tabular}{cccccccc}
\hline & Spot & F1M & F3M & F12M & F3Y & F5Y & F10Y \\
\hline ADF & -1.56 & -1.55 & -1.54 & -1.97 & -1.62 & -1.78 & -2.14 \\
PP & -1.57 & -1.57 & -1.54 & -1.98 & -1.71 & -1.85 & -2.17 \\
DFGLS & -0.24 & -0.24 & -0.26 & -0.08 & -0.36 & -0.44 & -0.77 \\
ERS & 32.83 & 32.42 & 31.72 & 45.79 & 28.48 & 26.41 & 15.83 \\
NP MZa & -0.32 & -0.34 & -0.36 & -0.09 & -0.53 & -0.66 & -1.48 \\
NP MZt & -0.23 & -0.24 & -0.26 & -0.08 & -0.36 & -0.43 & -0.77 \\
NP MSB & 0.72 & 0.72 & 0.71 & 0.85 & 0.68 & 0.66 & 0.52 \\
NP MPT & 30.37 & 30.00 & 29.37 & 41.57 & 26.36 & 24.34 & 14.55 \\
\hline
\end{tabular}

CHF/USD, 1979-2020 for Spot, F1M, F3M \&F10Y, 1983-2020 for F3Y \& F5Y, 1988-2020 for F12M

\begin{tabular}{cccccccc}
\hline & Spot & F1M & F3M & F12M & F3Y & F5Y & F10Y \\
\hline ADF & -1.20 & -1.20 & -1.19 & -1.28 & -1.51 & -1.50 & -1.97 \\
PP & -1.20 & -1.20 & -1.19 & -1.2 & -1.52 & -1.49 & -1.91 \\
DFGLS & -0.50 & -0.51 & -0.55 & -1.02 & -0.15 & -0.37 & $-1.98^{* *}$ \\
ERS & 15.04 & 14.71 & 14.03 & 8.43 & 24.83 & 18.11 & $3.22 * *$ \\
NP MZa & -1.07 & -1.11 & -1.22 & -2.83 & -0.26 & -0.73 & $-8.18^{* *}$ \\
NP MZt & -0.49 & -0.51 & -0.55 & -1.01 & -0.15 & -0.37 & $-1.96^{*}$ \\
NP MSB & 0.46 & 0.46 & 0.45 & 0.36 & 0.59 & 0.50 & $0.24 *$ \\
NP MPT & 14.31 & 14.01 & 13.40 & 8.20 & 22.8 & 16.76 & $3.23 *$ \\
\hline
\end{tabular}

CAD/USD, 1979-2020 for all but F12M, for which 1986-2020

\begin{tabular}{cccccccc}
\hline & Spot & F1M & F3M & F12M & F3Y & F5Y & F10Y \\
\hline ADF & -1.87 & -1.88 & -1.89 & -1.87 & -2.10 & -2.23 & -2.03 \\
PP & -1.82 & -1.83 & -1.82 & -1.8 & -2.10 & -2.03 & -2.15 \\
DFGLS & $-1.72 *$ & $-1.72 *$ & $-1.73 *$ & -1.23 & $-1.92 *$ & $-2.12^{* *}$ & $-2.03 * *$ \\
ERS & $4.18^{*}$ & $4.17 *$ & $4.11^{*}$ & 8.53 & $3.45^{*}$ & $2.67 * *$ & $2.99 * *$ \\
NP MZa & $-6.18^{*}$ & $-6.2 *$ & $-6.28^{*}$ & -3.05 & $-7.63^{*}$ & $-9.59 * *$ & $-8.21 * *$ \\
NP MZt & $-1.71^{*}$ & $-1.71 *$ & $-1.73^{*}$ & -1.23 & $-1.91 *$ & $-2.16^{* *}$ & $-2.02 * *$ \\
NP MSB & 0.28 & 0.28 & $0.27 *$ & 0.4 & $0.25 *$ & $0.23 * *$ & $0.25 *$ \\
NP MPT & $4.13^{*}$ & $4.11 *$ & $4.06^{*}$ & 8.01 & $3.39 *$ & $2.67 * *$ & $3.00 * *$ \\
\hline
\end{tabular}


AUD/USD, 1979-2020 for all but F1M \& F12M, for which 1986-2020

\begin{tabular}{cccccccc}
\hline & Spot & F1M & F3M & F12M & F3Y & F5Y & F10Y \\
\hline ADF & -2.23 & -2.03 & -2.27 & -2.27 & -2.52 & $-2.62^{*}$ & $-2.76^{*}$ \\
PP & -2.23 & -2.17 & -2.27 & -2.37 & -2.56 & $-2.65^{*}$ & $-2.77^{*}$ \\
DFGLS & -0.43 & -1.38 & -0.42 & -1.13 & -0.49 & -0.61 & -0.86 \\
ERS & 19.79 & 6.89 & 20.59 & 10.27 & 21.06 & 18.72 & 13.78 \\
NP MZa & -0.8 & -3.79 & -0.76 & -2.6 & -0.86 & -1.11 & -1.79 \\
NP MZt & -0.43 & -1.38 & -0.42 & -1.12 & -0.49 & -0.6 & -0.86 \\
NP MSB & 0.54 & 0.36 & 0.55 & 0.43 & 0.57 & 0.54 & 0.48 \\
NP MPT & 18.03 & 6.46 & 18.73 & 9.36 & 19.06 & 16.93 & 12.48 \\
\hline
\end{tabular}

NZD/USD, 1979-2020 for Spot, 1985-2020 for F1M, F3M, F3Y, F5Y, 1987-2020 for F12M

\begin{tabular}{cccccccc} 
& Spot & F1M & F3M & F12M & F3Y & F5Y & F10Y \\
\hline ADF & $-2.71 *$ & -2.37 & -2.38 & -2.02 & -2.55 & $-2.61 *$ & -2.48 \\
PP & $-2.71^{*}$ & -2.35 & -2.36 & -2.05 & -2.49 & $-2.59 *$ & -2.48 \\
DFGLS & -0.50 & -1.00 & -0.95 & -1.49 & -0.57 & -0.47 & -0.40 \\
ERS & 24.00 & 11.35 & 12.14 & 5.73 & 20.62 & 23.15 & 23.72 \\
NP MZa & -0.80 & -2.27 & -2.10 & -4.57 & -0.99 & -0.78 & -0.67 \\
NP MZt & -0.50 & -0.99 & -0.95 & -1.48 & -0.56 & -0.46 & -0.40 \\
NP MSB & 0.62 & 0.44 & 0.45 & 0.32 & 0.57 & 0.60 & 0.60 \\
NP MPT & 21.62 & 10.29 & 10.98 & 5.43 & 18.36 & 20.54 & 21.10 \\
\hline
\end{tabular}

NOK/USD, 1979-2020 for Spot, F3Y, F5Y \& F10Y, 1981-2020 for F3M, 1985-2020 for F12M, 1986 for F1M

\begin{tabular}{cccccccc}
\hline & Spot & F1M & F3M & F12M & F3Y & F5Y & F10Y \\
\hline ADF & -2.01 & -1.68 & -2.02 & -2.07 & -2.13 & -2.19 & -2.37 \\
PP & -2.18 & -1.8 & -2.22 & -2.07 & -2.24 & -2.31 & -2.37 \\
DFGLS & -0.31 & $-1.66^{*}$ & -0.70 & -1.15 & -0.19 & -0.28 & -0.68 \\
ERS & 15.92 & $4.3 *$ & 10.23 & 10.01 & 20.95 & 20.03 & 13.37 \\
NP MZa & -0.70 & $-6.39 *$ & -2.02 & -2.64 & -0.36 & -0.53 & -1.55 \\
NP MZt & -0.31 & $-1.65^{*}$ & -0.70 & -1.14 & -0.19 & -0.27 & -0.68 \\
NP MSB & 0.44 & $0.26^{*}$ & 0.34 & 0.43 & 0.52 & 0.52 & 0.44 \\
NP MPT & 14.61 & $4.29 *$ & 9.44 & 9.26 & 19.09 & 18.24 & 12.21 \\
\hline
\end{tabular}


SEK/USD, 1979 or Spot \& F10Y, 1984 for F12M, 1987 for F1M, F3M, F3Y, F5Y

\begin{tabular}{cccccccc}
\hline & Spot & F1M & F3M & F12M & F3Y & F5Y & F10Y \\
\hline ADF & -2.32 & -1.76 & -1.78 & -2.01 & -2.09 & -2.38 & $-2.75^{*}$ \\
PP & -2.53 & -2.05 & -2.07 & -2.37 & -2.35 & $-2.68^{*}$ & $-2.89 * *$ \\
DFGLS & 0.06 & -1.12 & -1.17 & $-1.83^{*}$ & $-2.08^{* *}$ & $-2.19^{* *}$ & -0.83 \\
ERS & 33.6 & 7.10 & 6.77 & $3.75^{*}$ & $3.10^{* *}$ & $2.71 * *$ & 12.92 \\
NP MZa & 0.10 & -3.73 & -4.00 & $-6.99^{*}$ & $-9.67 * *$ & $-9.61 * *$ & -1.84 \\
NP MZt & 0.07 & -1.11 & -1.16 & $-1.82^{*}$ & $-2.06^{* *}$ & $-2.16^{* *}$ & -0.83 \\
NP MSB & 0.68 & 0.30 & 0.29 & $0.26^{*}$ & $0.21 * *$ & $0.22 * *$ & 0.45 \\
NP MPT & 30.34 & 6.70 & 6.40 & $3.70^{*}$ & $3.09 * *$ & $2.67 * *$ & 11.71 \\
\hline
\end{tabular}

\begin{tabular}{cccccccc}
\hline \multicolumn{7}{c}{ GBP/DEM, 1979-2020 } \\
\hline Spot & F1M & F3M & F12M & F3Y & F5Y & F10Y \\
\hline ADF & -1.45 & -1.45 & -1.44 & -1.44 & -1.55 & -1.82 & $-2.76^{*}$ \\
PP & -1.51 & -1.51 & -1.52 & -1.53 & -1.67 & -1.90 & $-2.72^{*}$ \\
DFGLS & -0.24 & -0.26 & -0.30 & -0.46 & -1.00 & $-1.69 *$ & $-2.00^{* *}$ \\
ERS & 22.69 & 22.08 & 20.77 & 16.55 & 8.54 & $4.23^{*}$ & $3.27 *$ \\
NP MZa & -0.41 & -0.45 & -0.54 & -0.94 & -2.83 & $-6.51 *$ & $-7.87 *$ \\
NP MZt & -0.23 & -0.25 & -0.30 & -0.46 & -1.00 & $-1.68^{*}$ & $-1.98^{* *}$ \\
NP MSB & 0.57 & 0.56 & 0.55 & 0.49 & 0.35 & $0.26^{*}$ & $0.25 *$ \\
NP MPT & 21.10 & 20.53 & 19.35 & 15.51 & 8.18 & $4.18^{*}$ & $3.12^{* *}$ \\
\hline
\end{tabular}

\begin{tabular}{cccccccc}
\hline \multicolumn{7}{c}{ JPY/DEM, 1979-2020 for all but F12M, for which 1980-2020 } \\
\hline & Spot & F1M & F3M & F12M & F3Y & F5Y & F10Y \\
\hline ADF & -2.28 & -2.28 & -2.28 & $-3.33^{* *}$ & -2.26 & -2.29 & -2.12 \\
PP & -2.39 & -2.39 & -2.40 & $-3.41^{* *}$ & -2.44 & -2.44 & -2.19 \\
DFGLS & -0.45 & -0.45 & -0.45 & -0.13 & -0.47 & -0.51 & -0.73 \\
ERS & 20.17 & 20.11 & 20.21 & 38.00 & 22.39 & 22.98 & 18.10 \\
NP MZa & -0.81 & -0.82 & -0.81 & -0.16 & -0.78 & -0.83 & -1.31 \\
NP MZt & -0.44 & -0.45 & -0.45 & -0.12 & -0.47 & -0.50 & -0.73 \\
NP MSB & 0.55 & 0.55 & 0.55 & 0.75 & 0.59 & 0.61 & 0.56 \\
NP MPT & 18.35 & 18.30 & 18.39 & 33.55 & 20.38 & 20.90 & 16.62 \\
\hline
\end{tabular}




\begin{tabular}{|c|c|c|c|c|c|c|c|}
\hline & Spot & $\mathrm{F} 1 \mathrm{M}$ & F3M & F12M & F3Y & F5Y & F10Y \\
\hline $\mathrm{ADF}$ & -0.35 & -0.35 & -0.36 & -0.22 & -0.43 & -0.76 & -2.17 \\
\hline PP & -0.20 & -0.2 & -0.20 & -0.05 & -0.23 & -0.52 & -1.92 \\
\hline DFGLS & 0.75 & 0.73 & 0.70 & 0.34 & -0.15 & -0.71 & $-2.14 * *$ \\
\hline ERS & 32.32 & 31.80 & 30.73 & 24.04 & 14.30 & 9.12 & $2.86^{* *}$ \\
\hline NP MZa & 1.27 & 1.25 & 1.22 & 0.66 & -0.37 & -2.16 & $-9.74 * *$ \\
\hline NP MZt & 0.75 & 0.74 & 0.71 & 0.35 & -0.15 & -0.71 & $-2.12 * *$ \\
\hline NP MSB & 0.59 & 0.59 & 0.58 & 0.52 & 0.40 & 0.33 & $0.22 * *$ \\
\hline NP MPT & 30.46 & 29.98 & 29.00 & 23.02 & 13.97 & 9.05 & $2.87 * *$ \\
\hline
\end{tabular}

Notes. The sample includes monthly exchange rates against the US dollar between January 1979 and February 2020. spot: spot exchange rate; F1M: 1-month maturity theoretical forward exchange rate, F3M: 3-month maturity theoretical forward exchange rate, and so on. ADF: augmented test of Dickey-Fuller (1979); PP: test of Phillips-Perron (1988); ERS DF: DF test with GLS detrending suggested by Elliott-Rothenberg-Stock (1996); ERS FPO: feasible point-optimal test of Elliott-Rothenberg-Stock (1996), NP MZa \& MZt \& MSB \& MPT: four tests suggested by Ng-Perron (2001). Null hypothesis is unit root for all tests. The $1 \%, 5 \%$, and $10 \%$ critical values are the following. ADF and PP: $-3.45,-2.87,-2.57$. ERS DF: $-2.57,-1.94,-1.62$. ERS FPO: 1.96, 3.23, 4.42. NP MZa -13.8, -8.1, -5.7. NP MZt: -2.58, -1.98, -1.62. NP MSB: 0.174, 0.233, 0.275. NP MPT: $1.78,3.17,4.45 . * * *, * *$, and * indicates rejection of the null hypothesis at $1 \%, 5 \%$, and $10 \%$ significance level, respectively. 
Table A2: Regression statistics of the one period change in the exchange rate on the previous period forward rate, annual frequency using January data of each year

\begin{tabular}{|c|c|c|c|c|c|c|c|c|c|c|c|c|c|c|}
\hline $\begin{array}{l}\text { Maturity } \\
\text { of } \\
\text { forward } \\
\text { rate } \\
\end{array}$ & & $\begin{array}{l}\text { DEM/ } \\
\text { USD }\end{array}$ & $\begin{array}{l}\text { GBP/ } \\
\text { USD }\end{array}$ & $\begin{array}{l}\text { JPY/ } \\
\text { USD }\end{array}$ & $\begin{array}{l}\mathrm{CHF} / \\
\mathrm{USD}\end{array}$ & $\begin{array}{l}\text { CAD/ } \\
\text { USD }\end{array}$ & $\begin{array}{l}\text { AUD/ } \\
\text { USD }\end{array}$ & $\begin{array}{l}\text { NZD/ } \\
\text { USD }\end{array}$ & $\begin{array}{l}\text { NOK/ } \\
\text { USD }\end{array}$ & $\begin{array}{l}\text { SEK/ } \\
\text { USD }\end{array}$ & $\begin{array}{l}\text { GBP/ } \\
\text { DEM }\end{array}$ & $\begin{array}{l}\text { JPY/ } \\
\text { DEM }\end{array}$ & $\begin{array}{l}\mathrm{CHF} / \\
\mathrm{DEM}\end{array}$ & $\begin{array}{l}\text { USD- } \\
\text { Pool }\end{array}$ \\
\hline \multirow[t]{5}{*}{ 1-year } & $\delta_{1}$ & -0.214 & -0.333 & -0.128 & -0.107 & -0.218 & -0.318 & -0.325 & -0.332 & -0.340 & -0.153 & -0.347 & -0.015 & -0.219 \\
\hline & $\mathrm{t}$ & -2.19 & -2.90 & -2.26 & -1.25 & -2.03 & -2.41 & -2.46 & -2.58 & -2.52 & -1.91 & -3.81 & -0.22 & -6.55 \\
\hline & $\mathrm{R} 2$ & 0.11 & 0.18 & 0.12 & 0.05 & 0.11 & 0.15 & 0.16 & 0.17 & 0.16 & 0.09 & 0.28 & 0.00 & 0.12 \\
\hline & DW & 1.62 & 1.69 & 1.41 & 1.93 & 1.91 & 1.95 & 1.92 & 1.74 & 1.63 & 2.04 & 1.89 & 2.30 & 1.83 \\
\hline & $\mathrm{N}$ & 41 & 41 & 40 & 32 & 34 & 34 & 33 & 35 & 36 & 41 & 40 & 32 & 326 \\
\hline \multirow[t]{5}{*}{ 3-year } & $\delta_{1}$ & -0.253 & -0.400 & -0.109 & -0.142 & -0.212 & -0.225 & -0.277 & -0.253 & -0.419 & -0.192 & -0.223 & -0.022 & -0.209 \\
\hline & $\mathrm{t}$ & -2.43 & -3.43 & -1.86 & -1.86 & -2.16 & -2.50 & -2.61 & -2.60 & -2.80 & -2.22 & -2.51 & -0.33 & -6.94 \\
\hline & $\mathrm{R} 2$ & 0.13 & 0.23 & 0.08 & 0.09 & 0.11 & 0.14 & 0.17 & 0.15 & 0.20 & 0.11 & 0.14 & 0.00 & 0.13 \\
\hline & DW & 1.62 & 1.68 & 1.45 & 1.75 & 1.93 & 2.00 & 2.09 & 1.91 & 1.69 & 2.02 & 2.10 & 2.31 & 1.86 \\
\hline & $\mathrm{N}$ & 41 & 41 & 41 & 37 & 41 & 41 & 35 & 41 & 33 & 41 & 41 & 37 & 351 \\
\hline \multirow[t]{5}{*}{ 5-year } & $\delta_{1}$ & -0.295 & -0.447 & -0.111 & -0.160 & -0.203 & -0.208 & -0.234 & -0.239 & -0.479 & -0.229 & -0.203 & -0.037 & -0.213 \\
\hline & $\mathrm{t}$ & -2.69 & -3.83 & -1.86 & -2.00 & -2.11 & -2.39 & -2.41 & -2.64 & -3.23 & -2.46 & -2.41 & -0.51 & -7.15 \\
\hline & $\mathrm{R} 2$ & 0.16 & 0.27 & 0.08 & 0.10 & 0.10 & 0.13 & 0.15 & 0.15 & 0.25 & 0.13 & 0.13 & 0.01 & 0.14 \\
\hline & DW & 1.61 & 1.67 & 1.44 & 1.75 & 1.94 & 2.03 & 2.15 & 1.95 & 1.71 & 2.00 & 2.12 & 2.28 & 1.88 \\
\hline & $\mathrm{N}$ & 41 & 41 & 41 & 37 & 41 & 41 & 35 & 41 & 33 & 41 & 41 & 37 & 351 \\
\hline \multirow[t]{5}{*}{10 -year } & $\delta_{1}$ & -0.377 & -0.449 & -0.122 & -0.205 & -0.162 & -0.151 & -0.164 & -0.188 & -0.281 & -0.253 & -0.166 & -0.072 & -0.200 \\
\hline & $\mathrm{t}$ & -3.13 & -4.27 & -1.94 & -2.36 & -1.97 & -2.03 & -2.09 & -2.42 & -3.63 & -2.62 & -2.29 & -0.94 & -7.50 \\
\hline & $\mathrm{R} 2$ & 0.20 & 0.32 & 0.09 & 0.12 & 0.09 & 0.10 & 0.12 & 0.13 & 0.25 & 0.15 & 0.12 & 0.02 & 0.15 \\
\hline & DW & 1.64 & 1.65 & 1.42 & 1.81 & 1.96 & 2.06 & 2.20 & 2.01 & 1.61 & 1.95 & 2.16 & 2.22 & 1.87 \\
\hline & $\mathrm{N}$ & 41 & 41 & 41 & 41 & 41 & 41 & 35 & 41 & 41 & 41 & 41 & 41 & 363 \\
\hline
\end{tabular}

Notes. Equation estimated: $s_{t+1}-s_{t}=\delta_{0}+\delta_{1} f_{t}^{(h)}+\varepsilon_{t+1}$, where $s_{t}$ denotes the spot exchange rate; $f_{t}^{(h)}$ denotes the $h$ period maturity forward rate; $h$ is showed in the first column. $\mathrm{t}$ : OLS t-statistics, R2: coefficient of determinant; DW: Durbin-Watson, N: number of observations. The sample includes January data in January 1979 - January 2020 (with a few data-driven exceptions). The maximum number of observations is 41 for currency pairs and 369 for the panel. 
Table A3 corresponds to Table 4 of the paper by showing the results for currency pairs beyond the DEM/USD rate.

\section{Table A3: Out-of-sample forecast evaluation, baseline results}

GBP/USD

Full sample, different forecast horizons

\begin{tabular}{|c|c|c|c|c|c|c|c|c|c|c|c|c|}
\hline & & \\
\hline & $1 \mathrm{M}$ & $3 \mathrm{M}$ & $6 \mathrm{M}$ & $12 \mathrm{M}$ & $24 \mathrm{M}$ & $36 \mathrm{M}$ & $48 \mathrm{M}$ & $60 \mathrm{M}$ & $\begin{array}{c}1993- \\
99 \\
\end{array}$ & $\begin{array}{c}2000- \\
06\end{array}$ & $\begin{array}{c}2007- \\
10\end{array}$ & $\begin{array}{c}2011- \\
20 \\
\end{array}$ \\
\hline & \multicolumn{12}{|c|}{ Mean squared forecast error (MSFE), random walk without drift $=100$} \\
\hline Forward & 100.11 & 99.65 & 99.22 & 97.08 & 97.38 & 98.58 & 101.31 & 96.43 & 62.10 & 123.11 & 102.53 & 91.35 \\
\hline $\mathrm{p}$ & $(0.532)$ & $(0.459)$ & $(0.438)$ & $(0.320)$ & $(0.351)$ & $(0.421)$ & $(0.572)$ & $(0.304)$ & $(0.046)$ & $(0.995)$ & $(0.610)$ & $(0.091)$ \\
\hline Model 3Y & 99.42 & 97.65 & 94.07 & 91.05 & 79.82 & 71.35 & 62.05 & 57.95 & 78.02 & 52.76 & 61.73 & 94.21 \\
\hline $\mathrm{p}(\mathrm{CW})$ & $(0.028)$ & $(0.017)$ & $(0.009)$ & $(0.012)$ & $(0.001)$ & $(0.000)$ & $(0.000)$ & $(0.000)$ & $(0.005)$ & $(0.000)$ & $(0.008)$ & $(0.051)$ \\
\hline Model 5Y & 99.37 & 97.36 & 93.26 & 90.76 & 79.34 & 72.72 & 65.84 & 65.46 & 93.15 & 60.21 & 66.04 & 78.14 \\
\hline $\mathrm{p}(\mathrm{CW})$ & $(0.021)$ & $(0.011)$ & $(0.005)$ & $(0.010)$ & $(0.001)$ & $(0.000)$ & $(0.000)$ & $(0.000)$ & $(0.026)$ & $(0.000)$ & $(0.008)$ & $(0.007)$ \\
\hline Model 10Y & 100.31 & 98.74 & 94.84 & 95.46 & 87.90 & 90.78 & 92.19 & 101.87 & 109.12 & 118.76 & 76.16 & 59.74 \\
\hline $\mathrm{p}(\mathrm{CW})$ & $(0.069)$ & $(0.020)$ & $(0.007)$ & $(0.010)$ & $(0.002)$ & $(0.002)$ & $(0.002)$ & $(0.008)$ & $(0.121)$ & $(0.198)$ & $(0.010)$ & $(0.000)$ \\
\hline \multirow{3}{*}{$\begin{array}{l}\text { Combined } \\
\mathrm{p}(\mathrm{CW})\end{array}$} & 99.49 & 97.41 & 93.25 & 90.90 & 80.17 & 75.44 & 70.11 & 71.07 & 91.91 & 71.10 & 67.43 & 75.55 \\
\hline & $(0.030)$ & $(0.011)$ & $(0.005)$ & $(0.009)$ & $(0.001)$ & $(0.000)$ & $(0.000)$ & $(0.000)$ & $(0.020)$ & $(0.000)$ & $(0.008)$ & $(0.005)$ \\
\hline & \multicolumn{12}{|c|}{ Correct sign prediction compared to the spot rate, \% } \\
\hline Forward & 50.3 & 48.3 & 47.1 & 49.9 & 47.2 & 44.6 & 49.8 & 64.7 & 44.0 & 42.9 & 37.5 & 49.1 \\
\hline $\mathrm{p}$ & $(0.578)$ & $(0.628)$ & $(0.678)$ & $(0.804)$ & $(0.899)$ & $(1.000)$ & $(0.999)$ & $(0.017)$ & n.a. & $(0.806)$ & $(0.996)$ & $(0.844)$ \\
\hline Model 3Y & 54.7 & 55.6 & 62.2 & 64.4 & 69.9 & 69.7 & 72.7 & 68.6 & 71.4 & 90.5 & 56.3 & 59.1 \\
\hline $\mathrm{p}$ & $(0.031)$ & $(0.020)$ & $(0.000)$ & $(0.000)$ & $(0.000)$ & $(0.000)$ & $(0.000)$ & $(0.000)$ & $(0.000)$ & $(0.000)$ & n.a. & $(0.002)$ \\
\hline Model 5Y & 54.4 & 56.1 & 64.1 & 66.4 & 70.2 & 69.1 & 74.6 & 70.0 & 69.0 & 84.5 & 56.3 & 63.6 \\
\hline $\mathrm{p}$ & $(0.042)$ & $(0.011)$ & $(0.000)$ & $(0.000)$ & $(0.000)$ & $(0.000)$ & $(0.000)$ & $(0.000)$ & $(0.000)$ & $(0.000)$ & n.a. & $(0.001)$ \\
\hline Model 10Y & 56.1 & 56.1 & 64.4 & 68.4 & 65.5 & 62.1 & 68.3 & 65.3 & 60.7 & 47.6 & 56.3 & 77.3 \\
\hline $\mathrm{p}$ & $(0.011)$ & $(0.008)$ & $(0.000)$ & $(0.000)$ & $(0.000)$ & $(0.000)$ & $(0.000)$ & $(0.004)$ & $(0.043)$ & $(0.058)$ & n.a. & $(0.000)$ \\
\hline \multirow{3}{*}{$\begin{array}{l}\text { Combined } \\
\mathrm{p}\end{array}$} & 56.1 & 56.7 & 63.9 & 66.7 & 69.6 & 67.3 & 74.6 & 70.3 & 66.7 & 77.4 & 56.3 & 65.5 \\
\hline & $(0.009)$ & $(0.006)$ & $(0.000)$ & $(0.000)$ & $(0.000)$ & $(0.000)$ & $(0.000)$ & $(0.000)$ & $(0.002)$ & $(0.000)$ & n.a. & $(0.000)$ \\
\hline & \multicolumn{12}{|c|}{ Correct sign prediction compared to the forward rate, \% } \\
\hline Model 3Y & 54.1 & 53.6 & 61.1 & 56.4 & 65.2 & 68.2 & 69.8 & 70.3 & 67.9 & 84.5 & 58.3 & 60.0 \\
\hline $\mathrm{p}$ & $(0.056)$ & $(0.287)$ & $(0.000)$ & $(0.006)$ & $(0.000)$ & $(0.000)$ & $(0.000)$ & $(0.000)$ & $(0.024)$ & $(0.000)$ & $(0.123)$ & $(0.000)$ \\
\hline Model 5Y & 55.5 & 58.6 & 64.1 & 63.2 & 68.1 & 72.5 & 77.8 & 73.9 & 66.7 & 91.7 & 56.3 & 69.1 \\
\hline $\mathrm{p}$ & $(0.018)$ & $(0.002)$ & $(0.000)$ & $(0.000)$ & $(0.000)$ & $(0.000)$ & $(0.000)$ & $(0.000)$ & $(0.115)$ & $(0.000)$ & n.a. & $(0.000)$ \\
\hline Model 10Y & 58.6 & 58.6 & 67.2 & 69.8 & 69.0 & 72.2 & 76.5 & 70.0 & 60.7 & 77.4 & 56.3 & 83.6 \\
\hline $\mathrm{p}$ & $(0.001)$ & $(0.001)$ & $(0.000)$ & $(0.000)$ & $(0.000)$ & $(0.000)$ & $(0.000)$ & $(0.000)$ & $(0.725)$ & $(0.000)$ & n.a. & $(0.000)$ \\
\hline \multirow{3}{*}{$\begin{array}{l}\text { Combined } \\
\mathrm{p}\end{array}$} & 56.4 & 58.9 & 63.9 & 63.0 & 68.1 & 72.2 & 77.1 & 73.3 & 65.5 & 89.3 & 56.3 & 70.9 \\
\hline & $(0.008)$ & $(0.001)$ & $(0.000)$ & $(0.000)$ & $(0.000)$ & $(0.000)$ & $(0.000)$ & $(0.000)$ & $(0.251)$ & $(0.000)$ & n.a. & $(0.000)$ \\
\hline & \multicolumn{12}{|c|}{ Mean annualized profit, \% per year } \\
\hline Carry trade & 0.5 & 1.1 & 0.7 & 0.5 & 0.5 & 0.8 & 0.8 & 0.1 & 0.9 & 2.4 & 0.2 & -0.3 \\
\hline $\mathrm{p}(=0)$ & $(0.404)$ & $(0.259)$ & $(0.317)$ & $(0.308)$ & $(0.241)$ & $(0.085)$ & $(0.048)$ & $(0.447)$ & $(0.055)$ & $(0.013)$ & $(0.446)$ & $(0.657)$ \\
\hline Model 3Y & 2.7 & 1.8 & 2.3 & 2.0 & 1.9 & 1.9 & 1.9 & 1.6 & 1.0 & 4.1 & 2.3 & 0.7 \\
\hline $\mathrm{p}(=0)$ & $(0.066)$ & $(0.122)$ & $(0.043)$ & $(0.024)$ & $(0.003)$ & $(0.000)$ & $(0.000)$ & $(0.000)$ & $(0.047)$ & $(0.000)$ & $(0.060)$ & $(0.173)$ \\
\hline $\mathrm{p}(=\mathrm{CT})$ & $(0.075)$ & $(0.337)$ & $(0.157)$ & $(0.130)$ & $(0.058)$ & $(0.058)$ & $(0.014)$ & $(0.000)$ & $(0.116)$ & $(0.000)$ & $(0.219)$ & $(0.241)$ \\
\hline Model 5Y & 3.8 & 4.0 & 3.2 & 2.8 & 2.5 & 2.3 & 2.3 & 1.8 & 1.0 & 4.6 & 2.1 & 1.7 \\
\hline $\mathrm{p}(=0)$ & $(0.014)$ & $(0.005)$ & $(0.009)$ & $(0.002)$ & $(0.000)$ & $(0.000)$ & $(0.000)$ & $(0.000)$ & $(0.052)$ & $(0.000)$ & $(0.086)$ & $(0.005)$ \\
\hline $\mathrm{p}(=\mathrm{CT})$ & $(0.042)$ & $(0.074)$ & $(0.062)$ & $(0.044)$ & $(0.011)$ & $(0.011)$ & $(0.000)$ & $(0.000)$ & $(0.347)$ & $(0.000)$ & $(0.248)$ & $(0.060)$ \\
\hline Model 10Y & 4.7 & 4.2 & 4.2 & 3.6 & 2.7 & 2.1 & 2.0 & 1.2 & 0.7 & 2.8 & 2.1 & 2.8 \\
\hline $\mathrm{p}(=0)$ & $(0.004)$ & $(0.003)$ & $(0.001)$ & $(0.000)$ & $(0.000)$ & $(0.000)$ & $(0.000)$ & $(0.000)$ & $(0.118)$ & $(0.002)$ & $(0.086)$ & $(0.000)$ \\
\hline $\mathrm{p}(=\mathrm{CT})$ & $(0.016)$ & $(0.068)$ & $(0.029)$ & $(0.010)$ & $(0.005)$ & $(0.027)$ & $(0.010)$ & $(0.022)$ & $(0.923)$ & $(0.342)$ & $(0.248)$ & $(0.002)$ \\
\hline Combined & 4.1 & 4.1 & 3.3 & 2.7 & 2.6 & 2.3 & 2.3 & 1.8 & 0.9 & 4.4 & 2.1 & 1.8 \\
\hline $\mathrm{p}(=0)$ & $(0.010)$ & $(0.004)$ & (0.006) & $(0.002)$ & $(0.000)$ & $(0.000)$ & $(0.000)$ & $(0.000)$ & $(0.064)$ & $(0.000)$ & $(0.086)$ & $(0.002)$ \\
\hline $\mathrm{p}(=\mathrm{CT})$ & $(0.032)$ & $(0.065)$ & $(0.052)$ & $(0.045)$ & $(0.008)$ & $(0.012)$ & $(0.000)$ & $(0.000)$ & $(0.759)$ & $(0.000)$ & $(0.248)$ & $(0.046)$ \\
\hline
\end{tabular}


Table A3 continued: Out-of-sample forecast evaluation, baseline results

JPY/USD

Full sample, different forecast horizons

\begin{tabular}{|c|c|c|c|c|c|c|c|c|c|c|c|}
\hline $1 \mathrm{M}$ & $3 \mathrm{M}$ & $6 \mathrm{M}$ & $12 \mathrm{M}$ & $24 \mathrm{M}$ & $36 \mathrm{M}$ & $48 \mathrm{M}$ & $60 \mathrm{M}$ & $\begin{array}{c}1993- \\
99\end{array}$ & $\begin{array}{c}2000- \\
06\end{array}$ & $\begin{array}{c}2007- \\
10\end{array}$ & $\begin{array}{c}2011- \\
20\end{array}$ \\
\hline \multicolumn{12}{|c|}{ Mean squared forecast error (MSFE), random walk without drift $=100$} \\
\hline $\begin{array}{r}101.04 \\
(0.840) \\
\end{array}$ & $\begin{array}{r}102.74 \\
(0.855) \\
\end{array}$ & $\begin{array}{r}104.40 \\
(0.840)\end{array}$ & $\begin{array}{r}110.98 \\
(0.932) \\
\end{array}$ & $\begin{array}{r}112.69 \\
(0.903) \\
\end{array}$ & $\begin{array}{r}110.34 \\
(0.842)\end{array}$ & $\begin{array}{r}111.15 \\
(0.837)\end{array}$ & $\begin{array}{r}118.49 \\
(0.895) \\
\end{array}$ & $\begin{array}{r}131.08 \\
(0.981)\end{array}$ & $\begin{array}{r}163.31 \\
(0.895) \\
\end{array}$ & $\begin{array}{r}56.30 \\
(0.014) \\
\end{array}$ & $\begin{array}{r}97.97 \\
(0.309)\end{array}$ \\
\hline $\begin{array}{r}100.07 \\
(0.478) \\
\end{array}$ & $\begin{array}{r}100.66 \\
(0.619) \\
\end{array}$ & $\begin{array}{r}101.44 \\
(0.646) \\
\end{array}$ & $\begin{array}{r}102.23 \\
(0.614) \\
\end{array}$ & $\begin{array}{r}105.73 \\
(0.770) \\
\end{array}$ & $\begin{array}{r}111.57 \\
(0.887) \\
\end{array}$ & $\begin{array}{r}114.35 \\
(0.914) \\
\end{array}$ & $\begin{array}{r}115.87 \\
(0.896) \\
\end{array}$ & $\begin{array}{r}132.37 \\
(0.972) \\
\end{array}$ & $\begin{array}{r}97.82 \\
(0.206) \\
\end{array}$ & $\begin{array}{r}110.33 \\
(0.997) \\
\end{array}$ & $\begin{array}{r}93.09 \\
(0.023) \\
\end{array}$ \\
\hline $\begin{array}{r}100.08 \\
(0.490) \\
\end{array}$ & $\begin{array}{r}100.69 \\
(0.650) \\
\end{array}$ & $\begin{array}{r}101.39 \\
(0.663) \\
\end{array}$ & $\begin{array}{r}101.98 \\
(0.609) \\
\end{array}$ & $\begin{array}{r}104.21 \\
(0.711) \\
\end{array}$ & $\begin{array}{r}108.35 \\
(0.842) \\
\end{array}$ & $\begin{array}{r}109.34 \\
(0.815) \\
\end{array}$ & $\begin{array}{r}110.56 \\
(0.758) \\
\end{array}$ & $\begin{array}{r}120.93 \\
(0.946) \\
\end{array}$ & $\begin{array}{r}110.09 \\
(0.496) \\
\end{array}$ & $\begin{array}{r}111.29 \\
(0.995) \\
\end{array}$ & $\begin{array}{r}93.51 \\
(0.023) \\
\end{array}$ \\
\hline $\begin{array}{l}100.24 \\
(0.513)\end{array}$ & $\begin{array}{r}101.09 \\
(0.658)\end{array}$ & $\begin{array}{r}101.66 \\
(0.605)\end{array}$ & $\begin{array}{r}101.50 \\
(0.422)\end{array}$ & $\begin{array}{r}99.94 \\
(0.202) \\
\end{array}$ & $\begin{array}{r}100.71 \\
(0.163)\end{array}$ & $\begin{array}{r}99.52 \\
(0.061) \\
\end{array}$ & $\begin{array}{r}102.41 \\
(0.142) \\
\end{array}$ & $\begin{array}{r}94.88 \\
(0.063) \\
\end{array}$ & $\begin{array}{r}138.49 \\
(0.663) \\
\end{array}$ & $\begin{array}{r}110.44 \\
(0.986) \\
\end{array}$ & $\begin{array}{r}94.73 \\
(0.037) \\
\end{array}$ \\
\hline $\begin{array}{r}100.09 \\
(0.494) \\
\end{array}$ & $\begin{array}{r}100.71 \\
(0.664) \\
\end{array}$ & $\begin{array}{r}101.31 \\
(0.658)\end{array}$ & $\begin{array}{r}101.53 \\
(0.557) \\
\end{array}$ & $\begin{array}{r}102.76 \\
(0.598) \\
\end{array}$ & $\begin{array}{r}106.19 \\
(0.766) \\
\end{array}$ & $\begin{array}{r}106.77 \\
(0.700) \\
\end{array}$ & $\begin{array}{r}108.27 \\
(0.660) \\
\end{array}$ & $\begin{array}{r}114.86 \\
(0.904) \\
\end{array}$ & $\begin{array}{r}113.26 \\
(0.527) \\
\end{array}$ & $\begin{array}{r}110.66 \\
(0.994) \\
\end{array}$ & $\begin{array}{r}93.72 \\
(0.024) \\
\end{array}$ \\
\hline
\end{tabular}

Correct sign prediction compared to the spot rate, \%

\begin{tabular}{|c|c|c|c|c|c|c|c|c|c|c|c|c|}
\hline $\begin{array}{l}\text { Forward } \\
\mathrm{p}\end{array}$ & $\begin{array}{r}48.3 \\
(0.968) \\
\end{array}$ & $\begin{array}{r}47.2 \\
(0.945) \\
\end{array}$ & $\begin{array}{r}55.7 \\
(0.000) \\
\end{array}$ & $\begin{array}{r}52.1 \\
(0.999) \\
\end{array}$ & $\begin{array}{r}57.5 \\
(0.986) \\
\end{array}$ & $\begin{array}{r}54.7 \\
(0.899) \\
\end{array}$ & $\begin{array}{r}55.6 \\
(0.814) \\
\end{array}$ & $\begin{array}{r}52.1 \\
\text { n.o. }\end{array}$ & $\begin{array}{r}50.0 \\
(0.915) \\
\end{array}$ & $\begin{array}{r}65.5 \\
\text { n.a. }\end{array}$ & $\begin{array}{r}72.9 \\
\text { n.a. } \\
\end{array}$ & $\begin{array}{r}41.8 \\
\text { n.a. }\end{array}$ \\
\hline $\begin{array}{l}\text { Model 3Y } \\
\mathrm{p}\end{array}$ & $\begin{array}{r}50.0 \\
(0.418) \\
\end{array}$ & $\begin{array}{r}54.7 \\
(0.030) \\
\end{array}$ & $\begin{array}{r}54.1 \\
(0.030) \\
\end{array}$ & $\begin{array}{r}51.9 \\
(0.031) \\
\end{array}$ & $\begin{array}{r}53.4 \\
(0.004) \\
\end{array}$ & $\begin{array}{r}47.4 \\
(0.577) \\
\end{array}$ & $\begin{array}{r}41.0 \\
(0.995) \\
\end{array}$ & $\begin{array}{r}44.9 \\
(0.948) \\
\end{array}$ & $\begin{array}{r}25.0 \\
(1.000) \\
\end{array}$ & $\begin{array}{r}53.6 \\
(0.001) \\
\end{array}$ & $\begin{array}{r}27.1 \\
\text { n.a. } \\
\end{array}$ & $\begin{array}{r}69.1 \\
(0.000) \\
\end{array}$ \\
\hline $\begin{array}{l}\text { Model 5Y } \\
\mathrm{p}\end{array}$ & $\begin{array}{r}48.9 \\
(0.575) \\
\end{array}$ & $\begin{array}{r}53.6 \\
(0.065) \\
\end{array}$ & $\begin{array}{r}53.2 \\
(0.040) \\
\end{array}$ & $\begin{array}{r}48.7 \\
(0.130) \\
\end{array}$ & $\begin{array}{r}51.6 \\
(0.008) \\
\end{array}$ & $\begin{array}{r}48.0 \\
(0.416) \\
\end{array}$ & $\begin{array}{r}43.8 \\
(0.914) \\
\end{array}$ & $\begin{array}{r}46.5 \\
(0.831) \\
\end{array}$ & $\begin{array}{r}42.9 \\
(0.919) \\
\end{array}$ & $\begin{array}{r}40.5 \\
(0.046) \\
\end{array}$ & $\begin{array}{r}27.1 \\
\text { n.a. } \\
\end{array}$ & $\begin{array}{r}67.3 \\
(0.000) \\
\end{array}$ \\
\hline $\begin{array}{l}\text { Model 10Y } \\
\mathrm{p}\end{array}$ & $\begin{array}{r}49.2 \\
(0.493) \\
\end{array}$ & $\begin{array}{r}51.1 \\
(0.324) \\
\end{array}$ & $\begin{array}{r}50.1 \\
(0.294) \\
\end{array}$ & $\begin{array}{r}47.0 \\
(0.200) \\
\end{array}$ & $\begin{array}{r}54.0 \\
(0.000) \\
\end{array}$ & $\begin{array}{r}52.6 \\
(0.009) \\
\end{array}$ & $\begin{array}{r}52.4 \\
(0.013) \\
\end{array}$ & $\begin{array}{r}49.5 \\
(0.406) \\
\end{array}$ & $\begin{array}{r}67.9 \\
(0.000) \\
\end{array}$ & $\begin{array}{r}35.7 \\
(0.231) \\
\end{array}$ & $\begin{array}{r}27.1 \\
\text { n.a. }\end{array}$ & $\begin{array}{r}64.5 \\
(0.001) \\
\end{array}$ \\
\hline $\begin{array}{l}\text { Combined } \\
\mathrm{p}\end{array}$ & $\begin{array}{r}48.9 \\
(0.566) \\
\end{array}$ & $\begin{array}{r}51.7 \\
(0.248) \\
\end{array}$ & $\begin{array}{r}52.7 \\
(0.059) \\
\end{array}$ & $\begin{array}{r}50.1 \\
(0.034) \\
\end{array}$ & $\begin{array}{r}53.1 \\
(0.001) \\
\end{array}$ & $\begin{array}{r}48.6 \\
(0.332) \\
\end{array}$ & $\begin{array}{r}45.4 \\
(0.775) \\
\end{array}$ & $\begin{array}{r}47.5 \\
(0.713) \\
\end{array}$ & $\begin{array}{r}48.8 \\
(0.626) \\
\end{array}$ & $\begin{array}{r}38.1 \\
(0.099) \\
\end{array}$ & $\begin{array}{r}27.1 \\
\text { n.a. }\end{array}$ & $\begin{array}{r}66.4 \\
(0.000) \\
\end{array}$ \\
\hline & \multicolumn{12}{|c|}{ Correct sign prediction compared to the forward rate, $\%$} \\
\hline $\begin{array}{l}\text { Model 3Y } \\
\mathrm{p}\end{array}$ & $\begin{array}{r}53.0 \\
(0.165) \\
\end{array}$ & $\begin{array}{r}55.0 \\
(0.106) \\
\end{array}$ & $\begin{array}{r}52.9 \\
(0.622) \\
\end{array}$ & $\begin{array}{r}55.6 \\
(0.000) \\
\end{array}$ & $\begin{array}{r}58.1 \\
(0.000) \\
\end{array}$ & $\begin{array}{r}61.2 \\
(0.099) \\
\end{array}$ & $\begin{array}{r}65.1 \\
(0.815) \\
\end{array}$ & $\begin{array}{r}70.3 \\
(0.828) \\
\end{array}$ & $\begin{array}{r}44.0 \\
(0.974) \\
\end{array}$ & $\begin{array}{r}76.2 \\
\text { n.a. }\end{array}$ & $\begin{array}{r}43.8 \\
\text { n.a. } \\
\end{array}$ & $\begin{array}{r}70.9 \\
(0.000) \\
\end{array}$ \\
\hline $\begin{array}{l}\text { Model 5Y } \\
\mathrm{p}\end{array}$ & $\begin{array}{r}53.3 \\
(0.129) \\
\end{array}$ & $\begin{array}{r}55.6 \\
(0.065) \\
\end{array}$ & $\begin{array}{r}53.2 \\
(0.575) \\
\end{array}$ & $\begin{array}{r}53.6 \\
(0.003) \\
\end{array}$ & $\begin{array}{r}57.5 \\
(0.000) \\
\end{array}$ & $\begin{array}{r}63.0 \\
(0.004) \\
\end{array}$ & $\begin{array}{r}67.9 \\
(0.038) \\
\end{array}$ & $\begin{array}{r}72.3 \\
(0.325) \\
\end{array}$ & $\begin{array}{r}47.6 \\
(0.859) \\
\end{array}$ & $\begin{array}{r}76.2 \\
\text { n.a. }\end{array}$ & $\begin{array}{r}43.8 \\
\text { n.a. } \\
\end{array}$ & $\begin{array}{r}73.6 \\
(0.000) \\
\end{array}$ \\
\hline $\begin{array}{l}\text { Model 10Y } \\
\mathrm{p}\end{array}$ & $\begin{array}{r}53.6 \\
(0.085) \\
\end{array}$ & $\begin{array}{r}55.6 \\
(0.063) \\
\end{array}$ & $\begin{array}{r}54.9 \\
(0.193) \\
\end{array}$ & $\begin{array}{r}53.8 \\
(0.000) \\
\end{array}$ & $\begin{array}{r}60.5 \\
(0.000) \\
\end{array}$ & $\begin{array}{r}69.1 \\
(0.000) \\
\end{array}$ & $\begin{array}{r}75.2 \\
(0.000) \\
\end{array}$ & $\begin{array}{r}78.5 \\
(0.000) \\
\end{array}$ & $\begin{array}{r}70.2 \\
(0.000) \\
\end{array}$ & $\begin{array}{c}76.2 \\
\text { n.a. }\end{array}$ & $\begin{array}{r}43.8 \\
\text { n.a. }\end{array}$ & $\begin{array}{r}74.5 \\
(0.000)\end{array}$ \\
\hline $\begin{array}{l}\text { Combined } \\
\mathrm{p}\end{array}$ & $\begin{array}{r}53.9 \\
(0.074) \\
\end{array}$ & $\begin{array}{r}54.7 \\
(0.144) \\
\end{array}$ & $\begin{array}{r}54.3 \\
(0.322) \\
\end{array}$ & $\begin{array}{r}54.1 \\
(0.001) \\
\end{array}$ & $\begin{array}{r}58.7 \\
(0.000) \\
\end{array}$ & $\begin{array}{r}64.5 \\
(0.000) \\
\end{array}$ & $\begin{array}{r}68.3 \\
(0.018) \\
\end{array}$ & $\begin{array}{r}72.3 \\
(0.231) \\
\end{array}$ & $\begin{array}{r}51.2 \\
(0.562) \\
\end{array}$ & $\begin{array}{c}76.2 \\
\text { n.a. }\end{array}$ & $\begin{array}{r}43.8 \\
\text { n.a. } \\
\end{array}$ & $\begin{array}{r}75.5 \\
(0.000) \\
\end{array}$ \\
\hline & \multicolumn{12}{|c|}{ Mean annualized profit, \% per year } \\
\hline $\begin{array}{l}\text { Carry trade } \\
\mathrm{p}(=0)\end{array}$ & $\begin{array}{r}3.4 \\
(0.049) \\
\end{array}$ & $\begin{array}{r}2.8 \\
(0.071) \\
\end{array}$ & $\begin{array}{r}0.6 \\
(0.368) \\
\end{array}$ & $\begin{array}{r}2.2 \\
(0.048) \\
\end{array}$ & $\begin{array}{r}1.8 \\
(0.045) \\
\end{array}$ & $\begin{array}{r}1.7 \\
(0.028) \\
\end{array}$ & $\begin{array}{r}1.9 \\
(0.004) \\
\end{array}$ & $\begin{array}{r}2.2 \\
(0.000) \\
\end{array}$ & $\begin{array}{r}1.1 \\
(0.287) \\
\end{array}$ & $\begin{array}{r}2.8 \\
(0.001) \\
\end{array}$ & $\begin{array}{r}-0.9 \\
(0.745) \\
\end{array}$ & $\begin{array}{r}2.6 \\
(0.032) \\
\end{array}$ \\
\hline $\begin{array}{l}\text { Model 3Y } \\
\mathrm{p}(=0) \\
\mathrm{p}(=\mathrm{CT})\end{array}$ & $\begin{array}{r}3.0 \\
(0.063) \\
(0.603) \\
\end{array}$ & $\begin{array}{r}2.0 \\
(0.133) \\
(0.757) \\
\end{array}$ & $\begin{array}{r}0.5 \\
(0.367) \\
(0.512) \\
\end{array}$ & $\begin{array}{r}2.1 \\
(0.040) \\
(0.554) \\
\end{array}$ & $\begin{array}{r}1.9 \\
(0.026) \\
(0.438) \\
\end{array}$ & $\begin{array}{r}1.1 \\
(0.087) \\
(0.865) \\
\end{array}$ & $\begin{array}{r}1.4 \\
(0.022) \\
(0.937) \\
\end{array}$ & $\begin{array}{r}1.7 \\
(0.001) \\
(0.966) \\
\end{array}$ & $\begin{array}{r}-1.5 \\
(0.800) \\
(0.927) \\
\end{array}$ & $\begin{array}{r}2.8 \\
(0.001) \\
\text { n.a. }\end{array}$ & $\begin{array}{r}-0.9 \\
(0.745) \\
\text { n.a. }\end{array}$ & $\begin{array}{r}2.9 \\
(0.017) \\
(0.042) \\
\end{array}$ \\
\hline $\begin{array}{l}\text { Model 5Y } \\
\mathrm{p}(=0) \\
\mathrm{p}(=\mathrm{CT})\end{array}$ & $\begin{array}{r}2.4 \\
(0.104) \\
(0.753) \\
\end{array}$ & $\begin{array}{r}1.7 \\
(0.170) \\
(0.784) \\
\end{array}$ & $\begin{array}{r}0.8 \\
(0.301) \\
(0.412) \\
\end{array}$ & $\begin{array}{r}1.6 \\
(0.099) \\
(0.741) \\
\end{array}$ & $\begin{array}{r}1.8 \\
(0.033) \\
(0.526) \\
\end{array}$ & $\begin{array}{r}1.4 \\
(0.039) \\
(0.737) \\
\end{array}$ & $\begin{array}{r}1.6 \\
(0.007) \\
(0.827) \\
\end{array}$ & $\begin{array}{r}2.0 \\
(0.000) \\
(0.863) \\
\end{array}$ & $\begin{array}{r}-0.5 \\
(0.611) \\
(0.844) \\
\end{array}$ & $\begin{array}{r}2.8 \\
(0.001) \\
\text { n.a. } \\
\end{array}$ & $\begin{array}{r}-0.9 \\
(0.745) \\
\text { n.a. }\end{array}$ & $\begin{array}{r}3.0 \\
(0.013) \\
(0.041) \\
\end{array}$ \\
\hline $\begin{array}{l}\text { Model 10Y } \\
\mathrm{p}(=0) \\
\mathrm{p}(=\mathrm{CT})\end{array}$ & $\begin{array}{r}3.0 \\
(0.082) \\
(0.585) \\
\end{array}$ & $\begin{array}{r}2.4 \\
(0.096) \\
(0.602) \\
\end{array}$ & $\begin{array}{r}1.6 \\
(0.162) \\
(0.121) \\
\end{array}$ & $\begin{array}{r}2.3 \\
(0.041) \\
(0.444) \\
\end{array}$ & $\begin{array}{r}2.5 \\
(0.010) \\
(0.015) \\
\end{array}$ & $\begin{array}{r}2.6 \\
(0.001) \\
(0.009) \\
\end{array}$ & $\begin{array}{r}2.7 \\
(0.000) \\
(0.008) \\
\end{array}$ & $\begin{array}{r}2.6 \\
(0.000) \\
(0.008) \\
\end{array}$ & $\begin{array}{r}3.9 \\
(0.012) \\
(0.005) \\
\end{array}$ & $\begin{array}{r}2.8 \\
(0.001) \\
\text { n.a. } \\
\end{array}$ & $\begin{array}{r}-0.9 \\
(0.745) \\
\text { n.a. }\end{array}$ & $\begin{array}{r}3.0 \\
(0.013) \\
(0.069) \\
\end{array}$ \\
\hline $\begin{array}{l}\text { Combined } \\
\mathrm{p}(=0) \\
\mathrm{p}(=\mathrm{CT})\end{array}$ & $\begin{array}{r}2.8 \\
(0.078) \\
(0.661)\end{array}$ & $\begin{array}{r}1.7 \\
(0.178) \\
(0.796)\end{array}$ & $\begin{array}{r}1.3 \\
(0.205) \\
(0.211)\end{array}$ & $\begin{array}{r}2.0 \\
(0.053) \\
(0.596)\end{array}$ & $\begin{array}{r}2.0 \\
(0.019) \\
(0.345)\end{array}$ & $\begin{array}{r}1.6 \\
(0.020) \\
(0.587)\end{array}$ & $\begin{array}{r}1.6 \\
(0.007) \\
(0.822)\end{array}$ & $\begin{array}{r}1.9 \\
(0.000) \\
(0.894)\end{array}$ & $\begin{array}{r}0.2 \\
(0.445) \\
(0.749)\end{array}$ & $\begin{array}{r}2.8 \\
(0.001) \\
\text { n.a. }\end{array}$ & $\begin{array}{r}-0.9 \\
(0.745) \\
\text { n.a. }\end{array}$ & $\begin{array}{r}3.0 \\
(0.012) \\
(0.032)\end{array}$ \\
\hline
\end{tabular}


Table A3 continued: Out-of-sample forecast evaluation, baseline results

Japanese yen - US dollar rate results when the sample for estimation starts in January 1985.

JPY/USD

Full sample, different forecast horizons

Different samples, 36M forecast

$\begin{array}{llllll}6 \mathrm{M} & 12 \mathrm{M} & 24 \mathrm{M} & 36 \mathrm{M} & 48 \mathrm{M} & 60 \mathrm{M}\end{array}$

\begin{tabular}{cccc}
\multicolumn{4}{c}{ horizon } \\
\hline $1993-$ & $2000-$ & $2007-$ & $2011-$ \\
99 & 06 & 10 & 20 \\
\hline
\end{tabular}

Mean squared forecast error (MSFE), random walk without drift $=100$

\begin{tabular}{|c|c|c|c|c|c|c|c|c|c|c|c|c|}
\hline $\begin{array}{l}\text { Forward } \\
p\end{array}$ & $\begin{array}{r}101.04 \\
(0.840) \\
\end{array}$ & $\begin{array}{l}102.74 \\
(0.855) \\
\end{array}$ & $\begin{array}{r}104.40 \\
(0.840) \\
\end{array}$ & $\begin{array}{r}110.98 \\
(0.932) \\
\end{array}$ & $\begin{array}{r}112.69 \\
(0.903) \\
\end{array}$ & $\begin{array}{r}110.34 \\
(0.842) \\
\end{array}$ & $\begin{array}{l}111.15 \\
(0.837) \\
\end{array}$ & $\begin{array}{r}118.49 \\
(0.895) \\
\end{array}$ & $\begin{array}{l}131.08 \\
(0.981) \\
\end{array}$ & $\begin{array}{r}163.31 \\
(0.895) \\
\end{array}$ & $\begin{array}{r}56.30 \\
(0.014) \\
\end{array}$ & $\begin{array}{r}97.97 \\
(0.309) \\
\end{array}$ \\
\hline $\begin{array}{l}\text { Model 3Y } \\
\mathrm{p}(\mathrm{CW})\end{array}$ & $\begin{array}{r}99.16 \\
(0.058) \\
\end{array}$ & $\begin{array}{r}97.68 \\
(0.039) \\
\end{array}$ & $\begin{array}{r}94.08 \\
(0.012) \\
\end{array}$ & $\begin{array}{r}88.43 \\
(0.002) \\
\end{array}$ & $\begin{array}{r}74.53 \\
(0.000) \\
\end{array}$ & $\begin{array}{r}66.63 \\
(0.000) \\
\end{array}$ & $\begin{array}{r}63.63 \\
(0.000) \\
\end{array}$ & $\begin{array}{r}66.36 \\
(0.000) \\
\end{array}$ & $\begin{array}{r}52.40 \\
(0.000) \\
\end{array}$ & $\begin{array}{r}58.99 \\
(0.000) \\
\end{array}$ & $\begin{array}{r}105.37 \\
(0.611) \\
\end{array}$ & $\begin{array}{r}68.58 \\
(0.008) \\
\end{array}$ \\
\hline $\begin{array}{l}\text { Model 5Y } \\
\mathrm{p}(\mathrm{CW})\end{array}$ & $\begin{array}{r}99.33 \\
(0.070) \\
\end{array}$ & $\begin{array}{r}98.23 \\
(0.051) \\
\end{array}$ & $\begin{array}{r}94.63 \\
(0.014) \\
\end{array}$ & $\begin{array}{r}88.85 \\
(0.002) \\
\end{array}$ & $\begin{array}{r}73.70 \\
(0.000) \\
\end{array}$ & $\begin{array}{r}65.42 \\
(0.000) \\
\end{array}$ & $\begin{array}{r}62.78 \\
(0.000) \\
\end{array}$ & $\begin{array}{r}70.12 \\
(0.000) \\
\end{array}$ & $\begin{array}{r}42.29 \\
(0.000) \\
\end{array}$ & $\begin{array}{r}83.24 \\
(0.007) \\
\end{array}$ & $\begin{array}{l}102.16 \\
(0.331) \\
\end{array}$ & $\begin{array}{r}71.94 \\
(0.006) \\
\end{array}$ \\
\hline $\begin{array}{l}\text { Model 10Y } \\
\mathrm{p}(\mathrm{CW})\end{array}$ & $\begin{array}{l}100.14 \\
(0.119) \\
\end{array}$ & $\begin{array}{l}100.45 \\
(0.100) \\
\end{array}$ & $\begin{array}{r}97.27 \\
(0.026) \\
\end{array}$ & $\begin{array}{r}90.91 \\
(0.001) \\
\end{array}$ & $\begin{array}{r}72.17 \\
(0.000) \\
\end{array}$ & $\begin{array}{r}63.74 \\
(0.000) \\
\end{array}$ & $\begin{array}{r}62.54 \\
(0.000) \\
\end{array}$ & $\begin{array}{r}78.75 \\
(0.000) \\
\end{array}$ & $\begin{array}{r}25.51 \\
(0.000) \\
\end{array}$ & $\begin{array}{r}120.80 \\
(0.055) \\
\end{array}$ & $\begin{array}{r}87.85 \\
(0.001) \\
\end{array}$ & $\begin{array}{r}82.26 \\
(0.003) \\
\end{array}$ \\
\hline $\begin{array}{l}\text { Combined } \\
\mathrm{p}(\mathrm{CW})\end{array}$ & $\begin{array}{r}99.45 \\
(0.078) \\
\end{array}$ & $\begin{array}{r}98.55 \\
(0.059) \\
\end{array}$ & $\begin{array}{r}94.88 \\
(0.015) \\
\end{array}$ & $\begin{array}{r}88.51 \\
(0.001) \\
\end{array}$ & $\begin{array}{r}72.17 \\
(0.000) \\
\end{array}$ & $\begin{array}{r}63.50 \\
(0.000) \\
\end{array}$ & $\begin{array}{r}60.29 \\
(0.000) \\
\end{array}$ & $\begin{array}{r}67.75 \\
(0.000) \\
\end{array}$ & $\begin{array}{r}37.26 \\
(0.000) \\
\end{array}$ & $\begin{array}{r}84.30 \\
(0.008) \\
\end{array}$ & $\begin{array}{r}98.12 \\
(0.106) \\
\end{array}$ & $\begin{array}{r}73.43 \\
(0.005) \\
\end{array}$ \\
\hline
\end{tabular}

$\begin{array}{llll}\mathrm{p}(\mathrm{CW}) & (0.059) & (0.015) & \text { Correct sign prediction compared to the spot rate, } \%\end{array}$

\begin{tabular}{|c|c|c|c|c|c|c|c|c|c|c|c|c|}
\hline $\begin{array}{l}\text { Forward } \\
\mathrm{p}\end{array}$ & $\begin{array}{r}48.3 \\
(0.968) \\
\end{array}$ & $\begin{array}{r}47.2 \\
(0.945) \\
\end{array}$ & $\begin{array}{r}55.7 \\
(0.000) \\
\end{array}$ & $\begin{array}{r}52.1 \\
(0.999) \\
\end{array}$ & $\begin{array}{r}57.5 \\
(0.986) \\
\end{array}$ & $\begin{array}{r}54.7 \\
(0.899) \\
\end{array}$ & $\begin{array}{r}55.6 \\
(0.814) \\
\end{array}$ & $\begin{array}{r}52.1 \\
\text { n.o. }\end{array}$ & $\begin{array}{r}50.0 \\
(0.915) \\
\end{array}$ & $\begin{array}{r}65.5 \\
\text { n.a. }\end{array}$ & $\begin{array}{l}72.9 \\
\text { n.a. }\end{array}$ & $\begin{array}{r}41.8 \\
\text { n.a. }\end{array}$ \\
\hline $\begin{array}{l}\text { Model 3Y } \\
\mathrm{p}\end{array}$ & $\begin{array}{r}55.5 \\
(0.013) \\
\end{array}$ & $\begin{array}{r}58.3 \\
(0.001) \\
\end{array}$ & $\begin{array}{r}59.7 \\
(0.000) \\
\end{array}$ & $\begin{array}{r}65.0 \\
(0.000) \\
\end{array}$ & $\begin{array}{r}72.6 \\
(0.000) \\
\end{array}$ & $\begin{array}{r}70.0 \\
(0.000) \\
\end{array}$ & $\begin{array}{r}63.5 \\
(0.000) \\
\end{array}$ & $\begin{array}{r}70.6 \\
(0.000) \\
\end{array}$ & $\begin{array}{r}85.7 \\
(0.000) \\
\end{array}$ & $\begin{array}{r}77.4 \\
(0.000) \\
\end{array}$ & $\begin{array}{r}39.6 \\
(0.053) \\
\end{array}$ & $\begin{array}{r}65.5 \\
(0.001) \\
\end{array}$ \\
\hline $\begin{array}{l}\text { Model 5Y } \\
\mathrm{p}\end{array}$ & $\begin{array}{r}55.5 \\
(0.015) \\
\end{array}$ & $\begin{array}{r}58.6 \\
(0.001) \\
\end{array}$ & $\begin{array}{r}59.9 \\
(0.000) \\
\end{array}$ & $\begin{array}{r}65.5 \\
(0.000) \\
\end{array}$ & $\begin{array}{r}69.9 \\
(0.000) \\
\end{array}$ & $\begin{array}{r}67.9 \\
(0.000) \\
\end{array}$ & $\begin{array}{r}62.9 \\
(0.000) \\
\end{array}$ & $\begin{array}{r}67.7 \\
(0.000) \\
\end{array}$ & $\begin{array}{r}88.1 \\
(0.000) \\
\end{array}$ & $\begin{array}{r}71.4 \\
(0.000) \\
\end{array}$ & $\begin{array}{r}43.8 \\
(0.028) \\
\end{array}$ & $\begin{array}{r}60.0 \\
(0.021) \\
\end{array}$ \\
\hline $\begin{array}{l}\text { Model 10Y } \\
\mathrm{p}\end{array}$ & $\begin{array}{r}53.6 \\
(0.076) \\
\end{array}$ & $\begin{array}{r}60.0 \\
(0.000) \\
\end{array}$ & $\begin{array}{r}58.5 \\
(0.000) \\
\end{array}$ & $\begin{array}{r}63.2 \\
(0.000) \\
\end{array}$ & $\begin{array}{r}72.6 \\
(0.000) \\
\end{array}$ & $\begin{array}{r}70.0 \\
(0.000) \\
\end{array}$ & $\begin{array}{r}66.3 \\
(0.000) \\
\end{array}$ & $\begin{array}{r}69.6 \\
(0.000) \\
\end{array}$ & $\begin{array}{r}90.5 \\
(0.000) \\
\end{array}$ & $\begin{array}{r}59.5 \\
(0.002) \\
\end{array}$ & $\begin{array}{r}77.1 \\
(0.000) \\
\end{array}$ & $\begin{array}{r}59.1 \\
(0.027) \\
\end{array}$ \\
\hline $\begin{array}{l}\text { Combined } \\
\mathrm{p}\end{array}$ & $\begin{array}{r}55.5 \\
(0.015) \\
\end{array}$ & $\begin{array}{r}58.1 \\
(0.001) \\
\end{array}$ & $\begin{array}{r}59.9 \\
(0.000) \\
\end{array}$ & $\begin{array}{r}65.8 \\
(0.000) \\
\end{array}$ & $\begin{array}{r}72.0 \\
(0.000) \\
\end{array}$ & $\begin{array}{r}70.9 \\
(0.000) \\
\end{array}$ & $\begin{array}{r}66.3 \\
(0.000) \\
\end{array}$ & $\begin{array}{r}70.3 \\
(0.000) \\
\end{array}$ & $\begin{array}{r}91.7 \\
(0.000) \\
\end{array}$ & $\begin{array}{r}71.4 \\
(0.000) \\
\end{array}$ & $\begin{array}{r}60.4 \\
(0.001) \\
\end{array}$ & $\begin{array}{r}59.1 \\
(0.032) \\
\end{array}$ \\
\hline & \multicolumn{12}{|c|}{ Correct sign prediction compared to the forward rate, $\%$} \\
\hline $\begin{array}{l}\text { Model 3Y } \\
\text { p }\end{array}$ & $\begin{array}{r}53.9 \\
(0.091) \\
\end{array}$ & $\begin{array}{r}60.3 \\
(0.000) \\
\end{array}$ & $\begin{array}{r}61.1 \\
(0.000) \\
\end{array}$ & $\begin{array}{r}61.3 \\
(0.000) \\
\end{array}$ & $\begin{array}{r}67.8 \\
(0.000) \\
\end{array}$ & $\begin{array}{r}72.8 \\
(0.000) \\
\end{array}$ & $\begin{array}{r}79.0 \\
(0.000) \\
\end{array}$ & $\begin{array}{r}82.5 \\
(0.000) \\
\end{array}$ & $\begin{array}{r}85.7 \\
(0.000) \\
\end{array}$ & $\begin{array}{r}78.6 \\
(0.007) \\
\end{array}$ & $\begin{array}{r}43.8 \\
\text { n.a. }\end{array}$ & $\begin{array}{r}70.9 \\
(0.000) \\
\end{array}$ \\
\hline $\begin{array}{l}\text { Model 5Y } \\
\mathrm{p}\end{array}$ & $\begin{array}{r}53.0 \\
(0.163) \\
\end{array}$ & $\begin{array}{r}60.0 \\
(0.000) \\
\end{array}$ & $\begin{array}{r}60.5 \\
(0.000) \\
\end{array}$ & $\begin{array}{r}59.5 \\
(0.000) \\
\end{array}$ & $\begin{array}{r}65.5 \\
(0.000) \\
\end{array}$ & $\begin{array}{r}73.4 \\
(0.000) \\
\end{array}$ & $\begin{array}{r}80.3 \\
(0.000) \\
\end{array}$ & $\begin{array}{r}82.2 \\
(0.000) \\
\end{array}$ & $\begin{array}{r}91.7 \\
(0.000) \\
\end{array}$ & $\begin{array}{r}78.6 \\
(0.007) \\
\end{array}$ & $\begin{array}{c}43.8 \\
\text { n.a. }\end{array}$ & $\begin{array}{r}68.2 \\
(0.000) \\
\end{array}$ \\
\hline $\begin{array}{l}\text { Model 10Y } \\
\mathrm{p}\end{array}$ & $\begin{array}{r}51.1 \\
(0.430) \\
\end{array}$ & $\begin{array}{r}58.1 \\
(0.003) \\
\end{array}$ & $\begin{array}{r}57.7 \\
(0.007) \\
\end{array}$ & $\begin{array}{r}56.7 \\
(0.001) \\
\end{array}$ & $\begin{array}{r}63.4 \\
(0.000) \\
\end{array}$ & $\begin{array}{r}72.5 \\
(0.000) \\
\end{array}$ & $\begin{array}{r}78.4 \\
(0.000) \\
\end{array}$ & $\begin{array}{r}76.6 \\
(0.000) \\
\end{array}$ & $\begin{array}{r}98.8 \\
(0.000) \\
\end{array}$ & $\begin{array}{r}78.6 \\
(0.005) \\
\end{array}$ & $\begin{array}{r}43.8 \\
\text { n.a. }\end{array}$ & $\begin{array}{r}60.0 \\
(0.044) \\
\end{array}$ \\
\hline $\begin{array}{l}\text { Combined } \\
\mathrm{p}\end{array}$ & $\begin{array}{r}52.5 \\
(0.225) \\
\end{array}$ & $\begin{array}{r}59.4 \\
(0.001) \\
\end{array}$ & $\begin{array}{r}59.9 \\
(0.000) \\
\end{array}$ & $\begin{array}{r}59.3 \\
(0.000) \\
\end{array}$ & $\begin{array}{r}64.3 \\
(0.000) \\
\end{array}$ & $\begin{array}{r}73.4 \\
(0.000) \\
\end{array}$ & $\begin{array}{r}81.0 \\
(0.000) \\
\end{array}$ & $\begin{array}{r}81.5 \\
(0.000) \\
\end{array}$ & $\begin{array}{r}91.7 \\
(0.000) \\
\end{array}$ & $\begin{array}{r}78.6 \\
(0.007) \\
\end{array}$ & $\begin{array}{r}43.8 \\
\text { n.a. }\end{array}$ & $\begin{array}{r}68.2 \\
(0.000) \\
\end{array}$ \\
\hline & \multicolumn{12}{|c|}{ Mean annualized profit, \% per year } \\
\hline $\begin{array}{l}\text { Carry trade } \\
\mathrm{p}(=0)\end{array}$ & $\begin{array}{r}3.4 \\
(0.049) \\
\end{array}$ & $\begin{array}{r}2.8 \\
(0.071) \\
\end{array}$ & $\begin{array}{r}0.6 \\
(0.368) \\
\end{array}$ & $\begin{array}{r}2.2 \\
(0.048) \\
\end{array}$ & $\begin{array}{r}1.8 \\
(0.045) \\
\end{array}$ & $\begin{array}{r}1.7 \\
(0.028) \\
\end{array}$ & $\begin{array}{r}1.9 \\
(0.004) \\
\end{array}$ & $\begin{array}{r}2.2 \\
(0.000) \\
\end{array}$ & $\begin{array}{r}1.1 \\
(0.287) \\
\end{array}$ & $\begin{array}{r}2.8 \\
(0.001) \\
\end{array}$ & $\begin{array}{r}-0.9 \\
(0.745) \\
\end{array}$ & $\begin{array}{r}2.6 \\
(0.032) \\
\end{array}$ \\
\hline $\begin{array}{l}\text { Model 3Y } \\
\mathrm{p}(=0) \\
\mathrm{p}(=\mathrm{CT})\end{array}$ & $\begin{array}{r}4.9 \\
(0.011) \\
(0.265) \\
\end{array}$ & $\begin{array}{r}4.5 \\
(0.007) \\
(0.175) \\
\end{array}$ & $\begin{array}{r}3.9 \\
(0.006) \\
(0.011) \\
\end{array}$ & $\begin{array}{r}3.6 \\
(0.002) \\
(0.068) \\
\end{array}$ & $\begin{array}{r}3.5 \\
(0.000) \\
(0.001) \\
\end{array}$ & $\begin{array}{r}3.3 \\
(0.000) \\
(0.002) \\
\end{array}$ & $\begin{array}{r}3.3 \\
(0.000) \\
(0.001) \\
\end{array}$ & $\begin{array}{r}3.1 \\
(0.000) \\
(0.002) \\
\end{array}$ & $\begin{array}{r}6.8 \\
(0.000) \\
(0.000) \\
\end{array}$ & $\begin{array}{r}2.8 \\
(0.001) \\
(0.017) \\
\end{array}$ & $\begin{array}{r}-0.9 \\
(0.745) \\
\text { n.a. }\end{array}$ & $\begin{array}{r}2.9 \\
(0.016) \\
(0.135) \\
\end{array}$ \\
\hline $\begin{array}{l}\text { Model 5Y } \\
\mathrm{p}(=0) \\
\mathrm{p}(=\mathrm{CT})\end{array}$ & $\begin{array}{r}2.8 \\
(0.080) \\
(0.629) \\
\end{array}$ & $\begin{array}{r}3.9 \\
(0.021) \\
(0.267) \\
\end{array}$ & $\begin{array}{r}3.3 \\
(0.023) \\
(0.036) \\
\end{array}$ & $\begin{array}{r}3.2 \\
(0.007) \\
(0.158) \\
\end{array}$ & $\begin{array}{r}3.3 \\
(0.001) \\
(0.005) \\
\end{array}$ & $\begin{array}{r}3.6 \\
(0.000) \\
(0.001) \\
\end{array}$ & $\begin{array}{r}3.4 \\
(0.000) \\
(0.001) \\
\end{array}$ & $\begin{array}{r}3.1 \\
(0.000) \\
(0.002) \\
\end{array}$ & $\begin{array}{r}8.1 \\
(0.000) \\
(0.000) \\
\end{array}$ & $\begin{array}{r}2.8 \\
(0.001) \\
(0.017) \\
\end{array}$ & $\begin{array}{r}-0.9 \\
(0.745) \\
\text { n.a. } \\
\end{array}$ & $\begin{array}{r}2.8 \\
(0.020) \\
(0.273) \\
\end{array}$ \\
\hline $\begin{array}{l}\text { Model 10Y } \\
\mathrm{p}(=0) \\
\mathrm{p}(=\mathrm{CT})\end{array}$ & $\begin{array}{r}1.3 \\
(0.264) \\
(0.873) \\
\end{array}$ & $\begin{array}{r}2.4 \\
(0.090) \\
(0.578) \\
\end{array}$ & $\begin{array}{r}2.6 \\
(0.052) \\
(0.100) \\
\end{array}$ & $\begin{array}{r}2.7 \\
(0.018) \\
(0.306) \\
\end{array}$ & $\begin{array}{r}3.2 \\
(0.000) \\
(0.026) \\
\end{array}$ & $\begin{array}{r}3.6 \\
(0.000) \\
(0.002) \\
\end{array}$ & $\begin{array}{r}3.1 \\
(0.000) \\
(0.006) \\
\end{array}$ & $\begin{array}{r}2.7 \\
(0.000) \\
(0.072) \\
\end{array}$ & $\begin{array}{r}8.7 \\
(0.000) \\
(0.000) \\
\end{array}$ & $\begin{array}{r}2.8 \\
(0.001) \\
(0.047) \\
\end{array}$ & $\begin{array}{r}-0.9 \\
(0.745) \\
\text { n.a. } \\
\end{array}$ & $\begin{array}{r}2.3 \\
(0.042) \\
(0.710) \\
\end{array}$ \\
\hline $\begin{array}{l}\text { Combined } \\
\mathrm{p}(=0) \\
\mathrm{p}(=\mathrm{CT})\end{array}$ & $\begin{array}{r}2.5 \\
(0.106) \\
(0.687)\end{array}$ & $\begin{array}{r}3.6 \\
(0.027) \\
(0.311)\end{array}$ & $\begin{array}{r}3.1 \\
(0.028) \\
(0.046)\end{array}$ & $\begin{array}{r}3.2 \\
(0.006) \\
(0.154)\end{array}$ & $\begin{array}{r}3.2 \\
(0.001) \\
(0.009)\end{array}$ & $\begin{array}{r}3.5 \\
(0.000) \\
(0.002)\end{array}$ & $\begin{array}{r}3.4 \\
(0.000) \\
(0.001)\end{array}$ & $\begin{array}{r}3.1 \\
(0.000) \\
(0.003)\end{array}$ & $\begin{array}{r}8.1 \\
(0.000) \\
(0.000)\end{array}$ & $\begin{array}{r}2.8 \\
(0.001) \\
(0.017)\end{array}$ & $\begin{array}{r}-0.9 \\
(0.745) \\
\text { n.a. }\end{array}$ & $\begin{array}{r}2.7 \\
(0.022) \\
(0.328)\end{array}$ \\
\hline
\end{tabular}


Table A3 continued: Out-of-sample forecast evaluation, baseline results

CHF/USD

Full sample, different forecast horizons

\begin{tabular}{|c|c|c|c|c|c|c|c|c|c|c|}
\hline & & & & & & & & & & \\
\hline $1 \mathrm{M}$ & $3 \mathrm{M}$ & $6 \mathrm{M}$ & $12 \mathrm{M}$ & $24 \mathrm{M}$ & $36 \mathrm{M}$ & $48 \mathrm{M}$ & $60 \mathrm{M}$ & $\begin{array}{c}1993- \\
99\end{array}$ & $\begin{array}{c}2000- \\
06\end{array}$ & $\begin{array}{c}2007- \\
10\end{array}$ \\
\hline
\end{tabular}

Mean squared forecast error (MSFE), random walk without drift $=100$

\begin{tabular}{|c|c|c|c|c|c|c|c|c|c|c|c|c|}
\hline $\begin{array}{l}\text { Forward } \\
\mathrm{p}\end{array}$ & $\begin{array}{l}100.85 \\
(0.886) \\
\end{array}$ & $\begin{array}{l}102.15 \\
(0.876) \\
\end{array}$ & $\begin{array}{l}103.88 \\
(0.896) \\
\end{array}$ & $\begin{array}{l}107.62 \\
(0.946) \\
\end{array}$ & $\begin{array}{l}113.87 \\
(0.963) \\
\end{array}$ & $\begin{array}{r}116.39 \\
(0.939) \\
\end{array}$ & $\begin{array}{l}105.10 \\
(0.657) \\
\end{array}$ & $\begin{array}{r}91.15 \\
(0.251) \\
\end{array}$ & $\begin{array}{l}158.63 \\
(1.000) \\
\end{array}$ & $\begin{array}{l}112.74 \\
(0.803) \\
\end{array}$ & $\begin{array}{r}35.13 \\
(0.000) \\
\end{array}$ & $\begin{array}{l}105.51 \\
(0.814) \\
\end{array}$ \\
\hline $\begin{array}{l}\text { Model 3Y } \\
\mathrm{p}(\mathrm{CW})\end{array}$ & $\begin{array}{l}100.56 \\
(0.332) \\
\end{array}$ & $\begin{array}{r}102.00 \\
(0.370) \\
\end{array}$ & $\begin{array}{r}104.40 \\
(0.381) \\
\end{array}$ & $\begin{array}{r}107.50 \\
(0.269) \\
\end{array}$ & $\begin{array}{l}108.25 \\
(0.107) \\
\end{array}$ & $\begin{array}{l}108.85 \\
(0.059) \\
\end{array}$ & $\begin{array}{l}114.62 \\
(0.089) \\
\end{array}$ & $\begin{array}{r}121.64 \\
(0.154) \\
\end{array}$ & $\begin{array}{r}47.68 \\
(0.000) \\
\end{array}$ & $\begin{array}{r}51.06 \\
(0.000) \\
\end{array}$ & $\begin{array}{l}306.60 \\
(1.000) \\
\end{array}$ & $\begin{array}{l}234.79 \\
(0.871) \\
\end{array}$ \\
\hline $\begin{array}{l}\text { Model 5Y } \\
\mathrm{p}(\mathrm{CW})\end{array}$ & $\begin{array}{l}100.86 \\
(0.204) \\
\end{array}$ & $\begin{array}{r}103.30 \\
(0.247) \\
\end{array}$ & $\begin{array}{l}106.74 \\
(0.228) \\
\end{array}$ & $\begin{array}{l}111.74 \\
(0.129) \\
\end{array}$ & $\begin{array}{r}112.83 \\
(0.033) \\
\end{array}$ & $\begin{array}{l}113.41 \\
(0.013) \\
\end{array}$ & $\begin{array}{l}122.15 \\
(0.027) \\
\end{array}$ & $\begin{array}{r}130.35 \\
(0.057) \\
\end{array}$ & $\begin{array}{r}24.17 \\
(0.000) \\
\end{array}$ & $\begin{array}{r}35.68 \\
(0.000) \\
\end{array}$ & $\begin{array}{l}366.67 \\
(1.000) \\
\end{array}$ & $\begin{array}{l}302.62 \\
(0.806) \\
\end{array}$ \\
\hline $\begin{array}{l}\text { Model 10Y } \\
\mathrm{p}(\mathrm{CW})\end{array}$ & $\begin{array}{l}102.75 \\
(0.085) \\
\end{array}$ & $\begin{array}{r}109.93 \\
(0.118) \\
\end{array}$ & $\begin{array}{l}118.52 \\
(0.075) \\
\end{array}$ & $\begin{array}{l}136.80 \\
(0.040) \\
\end{array}$ & $\begin{array}{l}141.12 \\
(0.006) \\
\end{array}$ & $\begin{array}{l}136.55 \\
(0.002) \\
\end{array}$ & $\begin{array}{l}136.18 \\
(0.001) \\
\end{array}$ & $\begin{array}{r}140.13 \\
(0.000) \\
\end{array}$ & $\begin{array}{r}118.00 \\
(0.000) \\
\end{array}$ & $\begin{array}{r}55.59 \\
(0.002) \\
\end{array}$ & $\begin{array}{l}210.69 \\
(1.000) \\
\end{array}$ & $\begin{array}{l}323.31 \\
(0.299) \\
\end{array}$ \\
\hline $\begin{array}{l}\text { Combined } \\
\mathrm{p}(\mathrm{CW})\end{array}$ & $\begin{array}{l}100.65 \\
(0.128) \\
\end{array}$ & $\begin{array}{r}102.99 \\
(0.170) \\
\end{array}$ & $\begin{array}{r}105.89 \\
(0.139) \\
\end{array}$ & $\begin{array}{l}110.96 \\
(0.078) \\
\end{array}$ & $\begin{array}{r}108.25 \\
(0.015) \\
\end{array}$ & $\begin{array}{r}103.61 \\
(0.005) \\
\end{array}$ & $\begin{array}{l}106.73 \\
(0.005) \\
\end{array}$ & $\begin{array}{r}111.84 \\
(0.008) \\
\end{array}$ & $\begin{array}{r}30.55 \\
(0.000) \\
\end{array}$ & $\begin{array}{r}37.99 \\
(0.000) \\
\end{array}$ & $\begin{array}{l}289.10 \\
(1.000) \\
\end{array}$ & $\begin{array}{r}277.05 \\
(0.680) \\
\end{array}$ \\
\hline
\end{tabular}

Correct sign prediction compared to the spot rate, \%

\begin{tabular}{|c|c|c|c|c|c|c|c|c|c|c|c|c|}
\hline $\begin{array}{l}\text { Forward } \\
\mathrm{p}\end{array}$ & $\begin{array}{r}51.4 \\
(0.545) \\
\end{array}$ & $\begin{array}{r}54.4 \\
(0.372) \\
\end{array}$ & $\begin{array}{r}51.3 \\
(0.487) \\
\end{array}$ & $\begin{array}{r}55.0 \\
(0.150) \\
\end{array}$ & $\begin{array}{r}50.4 \\
(0.966) \\
\end{array}$ & $\begin{array}{r}53.2 \\
(1.000) \\
\end{array}$ & $\begin{array}{r}55.2 \\
(0.999) \\
\end{array}$ & $\begin{array}{r}65.0 \\
(0.350) \\
\end{array}$ & $\begin{array}{r}21.4 \\
(1.000) \\
\end{array}$ & $\begin{array}{r}65.5 \\
\text { n.a. }\end{array}$ & $\begin{array}{r}100.0 \\
\text { n.a. }\end{array}$ & $\begin{array}{r}47.3 \\
(1.000) \\
\end{array}$ \\
\hline Model 3Y & 47.8 & 46.7 & 49.9 & 49.0 & 56.0 & 59.3 & 59.7 & 54.5 & 85.7 & 81.0 & 0.0 & 49.1 \\
\hline $\mathrm{p}$ & $(0.665)$ & $(0.512)$ & $(0.211)$ & $(0.192)$ & $(0.000)$ & $(0.000)$ & $(0.000)$ & $(0.000)$ & $(0.000)$ & $(0.000)$ & n.a. & n.a. \\
\hline Model 5Y & 48.3 & 47.8 & 51.8 & 51.3 & 58.1 & 62.4 & 61.6 & 54.8 & 96.4 & 81.0 & 0.0 & 49.1 \\
\hline $\mathrm{p}$ & $(0.570)$ & $(0.322)$ & $(0.045)$ & $(0.030)$ & $(0.000)$ & $(0.000)$ & $(0.000)$ & $(0.000)$ & $(0.000)$ & $(0.000)$ & n.a. & n.a. \\
\hline Model 10Y & 50.6 & 51.9 & 53.2 & 53.3 & 55.8 & 56.0 & 60.3 & 62.4 & 73.8 & 65.5 & 14.6 & 52.7 \\
\hline $\mathrm{p}$ & $(0.344)$ & $(0.114)$ & $(0.070)$ & $(0.059)$ & $(0.010)$ & $(0.008)$ & $(0.000)$ & $(0.000)$ & $(0.000)$ & $(0.320)$ & n.a. & $(0.000)$ \\
\hline \multirow{3}{*}{$\begin{array}{l}\text { Combined } \\
\mathrm{p}\end{array}$} & 50.0 & 49.4 & 51.8 & 51.3 & 54.3 & 58.4 & 62.5 & 64.0 & 90.5 & 71.4 & 0.0 & 49.1 \\
\hline & $(0.364)$ & $(0.262)$ & $(0.109)$ & $(0.106)$ & $(0.011)$ & $(0.000)$ & $(0.000)$ & $(0.000)$ & $(0.000)$ & $(0.002)$ & n.a. & n.a. \\
\hline & \multicolumn{12}{|c|}{ Correct sign prediction compared to the forward rate, \% } \\
\hline Model 3Y & 51.1 & 51.9 & 58.3 & 59.3 & 66.7 & 66.7 & 64.1 & 54.1 & 91.7 & 77.4 & 12.5 & 63.6 \\
\hline $\mathrm{p}$ & $(0.415)$ & $(0.161)$ & $(0.000)$ & $(0.000)$ & $(0.000)$ & $(0.000)$ & $(0.000)$ & $(0.001)$ & $(0.000)$ & $(0.000)$ & n.a. & n.a. \\
\hline Model 5Y & 50.8 & 52.8 & 58.3 & 61.3 & 67.6 & 69.1 & 66.7 & 57.1 & 96.4 & 82.1 & 12.5 & 63.6 \\
\hline $\mathrm{p}$ & $(0.468)$ & $(0.082)$ & $(0.000)$ & $(0.000)$ & $(0.000)$ & $(0.000)$ & $(0.000)$ & $(0.000)$ & $(0.000)$ & $(0.000)$ & n.a. & n.a. \\
\hline Model 10Y & 53.9 & 55.3 & 58.8 & 59.8 & 65.5 & 64.2 & 63.2 & 62.0 & 75.0 & 78.6 & 14.6 & 66.4 \\
\hline $\mathrm{p}$ & $(0.079)$ & $(0.016)$ & $(0.000)$ & $(0.000)$ & $(0.000)$ & $(0.000)$ & $(0.000)$ & $(0.000)$ & $(0.000)$ & $(0.000)$ & $(0.350)$ & $(0.000)$ \\
\hline Combined & 51.1 & 52.8 & 58.3 & 59.5 & 67.0 & 68.8 & 66.3 & 60.1 & 90.5 & 84.5 & 12.5 & 64.5 \\
\hline \multirow[t]{2}{*}{$\mathrm{p}$} & $(0.408)$ & $(0.095)$ & $(0.001)$ & $(0.000)$ & $(0.000)$ & $(0.000)$ & $(0.000)$ & $(0.000)$ & $(0.000)$ & $(0.000)$ & n.a. & $(0.000)$ \\
\hline & \multicolumn{12}{|c|}{ Mean annualized profit, \% per year } \\
\hline Carry trade & 0.5 & 0.4 & 0.8 & 0.6 & 1.0 & 1.1 & 0.5 & 0.1 & 5.1 & -0.2 & -1.9 & 0.3 \\
\hline $\mathrm{p}(=0)$ & $(0.404)$ & $(0.401)$ & $(0.285)$ & $(0.285)$ & $(0.129)$ & $(0.058)$ & $(0.187)$ & $(0.415)$ & $(0.000)$ & $(0.551)$ & $(1.000)$ & $(0.294)$ \\
\hline Model 3Y & 1.4 & 1.3 & 1.9 & 2.1 & 2.6 & 2.6 & 1.6 & 0.9 & 5.9 & 5.4 & -1.9 & -0.1 \\
\hline $\mathrm{p}(=0)$ & $(0.236)$ & $(0.229)$ & $(0.104)$ & $(0.028)$ & $(0.001)$ & $(0.000)$ & $(0.003)$ & $(0.037)$ & $(0.000)$ & $(0.000)$ & $(1.000)$ & $(0.533)$ \\
\hline $\mathrm{p}(=\mathrm{CT})$ & $(0.250)$ & $(0.252)$ & $(0.237)$ & $(0.064)$ & $(0.012)$ & $(0.005)$ & $(0.009)$ & $(0.008)$ & $(0.000)$ & $(0.000)$ & n.a. & $(0.937)$ \\
\hline Model 5Y & 1.7 & 2.0 & 1.8 & 2.6 & 2.8 & 2.7 & 1.8 & 1.1 & 6.2 & 5.8 & -1.9 & -0.1 \\
\hline $\mathrm{p}(=0)$ & $(0.169)$ & $(0.112)$ & $(0.097)$ & $(0.010)$ & $(0.000)$ & $(0.000)$ & $(0.001)$ & $(0.018)$ & $(0.000)$ & $(0.000)$ & $(1.000)$ & $(0.533)$ \\
\hline $\mathrm{p}(=\mathrm{CT})$ & $(0.210)$ & $(0.145)$ & $(0.253)$ & $(0.029)$ & $(0.005)$ & $(0.002)$ & $(0.003)$ & $(0.004)$ & $(0.000)$ & $(0.000)$ & n.a. & $(0.937)$ \\
\hline Model 10Y & 3.8 & 2.5 & 1.8 & 2.1 & 2.0 & 1.9 & 1.6 & 1.4 & 4.4 & 3.4 & -1.8 & 0.4 \\
\hline $\mathrm{p}(=0)$ & $(0.035)$ & $(0.077)$ & $(0.104)$ & $(0.022)$ & $(0.005)$ & $(0.001)$ & $(0.002)$ & $(0.001)$ & $(0.000)$ & $(0.001)$ & (1.000) & $(0.277)$ \\
\hline $\mathrm{p}(=\mathrm{CT})$ & $(0.035)$ & $(0.090)$ & $(0.274)$ & $(0.117)$ & $(0.138)$ & $(0.161)$ & $(0.040)$ & $(0.003)$ & $(0.893)$ & $(0.057)$ & $(0.010)$ & $(0.445)$ \\
\hline Combined & 1.5 & 1.6 & 2.0 & 2.2 & 2.8 & 2.7 & 1.9 & 1.2 & 5.7 & 5.9 & -1.9 & 0.1 \\
\hline $\mathrm{p}(=0)$ & $(0.210)$ & $(0.171)$ & $(0.090)$ & $(0.019)$ & $(0.000)$ & $(0.000)$ & $(0.000)$ & $(0.008)$ & $(0.000)$ & $(0.000)$ & $(1.000)$ & $(0.434)$ \\
\hline $\mathrm{p}(=\mathrm{CT})$ & $(0.188)$ & $(0.146)$ & $(0.214)$ & $(0.051)$ & $(0.006)$ & $(0.003)$ & $(0.002)$ & $(0.001)$ & $(0.032)$ & $(0.000)$ & n.a. & $(0.938)$ \\
\hline
\end{tabular}


Table A3 continued: Out-of-sample forecast evaluation, baseline results

CAD/USD

Full sample, different forecast horizons

Different samples, 36M forecast

\section{CAD/USD}

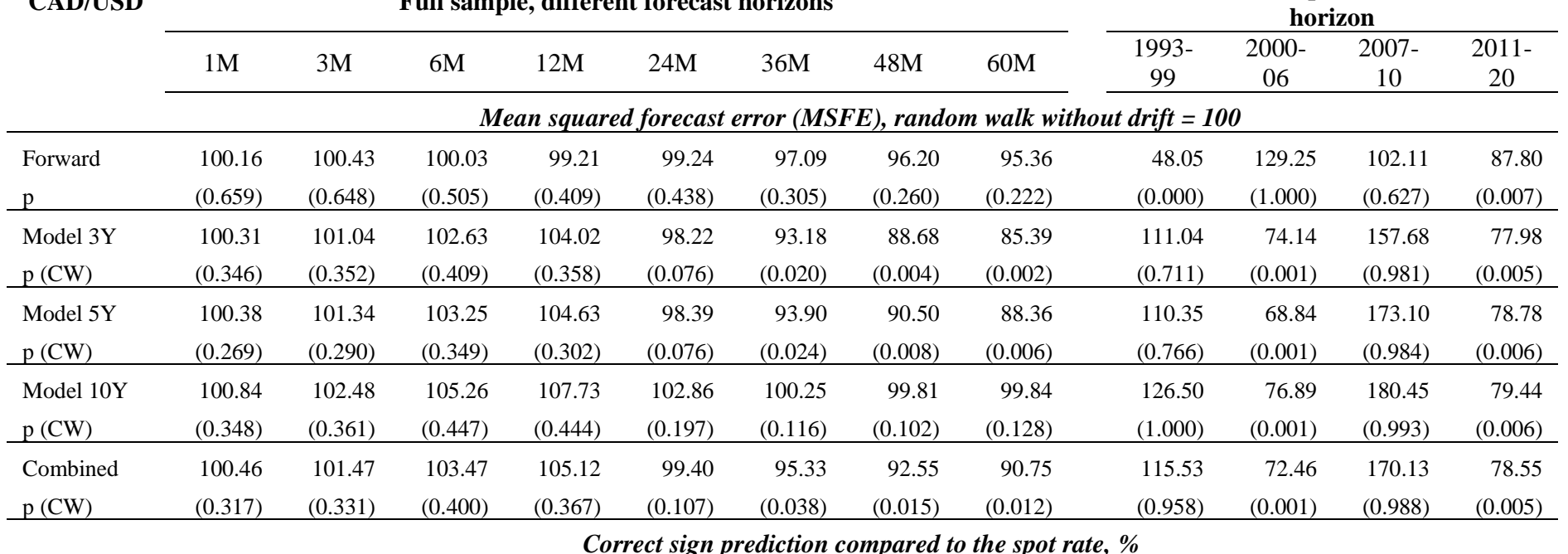

Correct sign prediction compared to the spot rate, $\%$

\begin{tabular}{|c|c|c|c|c|c|c|c|c|c|c|c|c|}
\hline \multicolumn{13}{|c|}{ Correct sign prediction compared to the spot rate, $\%$} \\
\hline Forward & 48.1 & 50.8 & 52.4 & 50.1 & 49.6 & 55.0 & 67.0 & 65.7 & 89.3 & 14.3 & 58.3 & 58.2 \\
\hline $\mathrm{p}$ & $(0.827)$ & $(0.476)$ & $(0.420)$ & $(0.754)$ & $(0.905)$ & $(0.367)$ & $(0.000)$ & $(0.000)$ & $(0.698)$ & (1.000) & $(0.393)$ & $(0.100)$ \\
\hline Model 3Y & 49.2 & 51.4 & 52.1 & 52.1 & 54.9 & 50.5 & 57.8 & 57.8 & 36.9 & 56.0 & 33.3 & 63.6 \\
\hline $\mathrm{p}$ & $(0.634)$ & $(0.321)$ & $(0.247)$ & $(0.260)$ & $(0.058)$ & $(0.538)$ & (0.007) & $(0.006)$ & $(0.078)$ & $(0.253)$ & $(0.135)$ & $(0.004)$ \\
\hline Model 5Y & 53.0 & 56.4 & 55.5 & 54.4 & 53.7 & 52.0 & 58.4 & 58.7 & 36.9 & 64.3 & 27.1 & 64.5 \\
\hline $\mathrm{p}$ & $(0.142)$ & $(0.013)$ & $(0.053)$ & $(0.104)$ & $(0.272)$ & $(0.545)$ & $(0.009)$ & $(0.004)$ & $(0.078)$ & $(0.003)$ & n.a. & $(0.000)$ \\
\hline Model 10Y & 52.8 & 56.9 & 54.1 & 54.4 & 55.5 & 50.5 & 46.7 & 44.6 & 17.9 & 81.0 & 27.1 & 61.8 \\
\hline $\mathrm{p}$ & $(0.175)$ & $(0.008)$ & $(0.178)$ & $(0.139)$ & $(0.184)$ & $(0.879)$ & (0.995) & (0.998) & $(0.212)$ & $(0.000)$ & n.a. & n.a. \\
\hline Combined & 52.2 & 56.4 & 54.1 & 52.7 & 51.9 & 51.1 & 57.1 & 55.8 & 32.1 & 66.7 & 27.1 & 63.6 \\
\hline \multirow[t]{2}{*}{$\mathrm{p}$} & $(0.226)$ & $(0.012)$ & $(0.135)$ & $(0.267)$ & $(0.496)$ & $(0.668)$ & $(0.029)$ & $(0.062)$ & $(0.103)$ & $(0.001)$ & n.a. & $(0.000)$ \\
\hline & \multicolumn{12}{|c|}{ Correct sign prediction compared to the forward rate, $\%$} \\
\hline Model 3Y & 50.0 & 55.8 & 54.6 & 57.8 & 55.5 & 54.7 & 56.5 & 56.4 & 31.0 & 67.9 & 47.9 & 66.4 \\
\hline $\mathrm{p}$ & $(0.496)$ & $(0.012)$ & $(0.037)$ & $(0.002)$ & $(0.023)$ & $(0.041)$ & $(0.008)$ & $(0.010)$ & $(0.076)$ & $(0.000)$ & $(0.017)$ & $(0.000)$ \\
\hline Model 5Y & 50.6 & 56.7 & 56.9 & 56.7 & 55.5 & 56.0 & 55.6 & 53.8 & 31.0 & 76.2 & 47.9 & 63.6 \\
\hline $\mathrm{p}$ & $(0.418)$ & $(0.007)$ & $(0.005)$ & $(0.007)$ & $(0.030)$ & $(0.021)$ & $(0.029)$ & $(0.105)$ & $(0.076)$ & $(0.000)$ & $(0.017)$ & $(0.000)$ \\
\hline Model 10Y & 52.2 & 58.1 & 58.5 & 58.4 & 59.0 & 56.6 & 49.8 & 47.5 & 29.8 & 85.7 & 35.4 & 64.5 \\
\hline $\mathrm{p}$ & $(0.199)$ & $(0.001)$ & $(0.001)$ & $(0.001)$ & $(0.002)$ & $(0.028)$ & $(0.687)$ & (0.867) & $(0.097)$ & $(0.000)$ & $(0.388)$ & $(0.000)$ \\
\hline Combined & 50.3 & 56.4 & 57.1 & 55.6 & 55.8 & 55.7 & 54.6 & 52.5 & 31.0 & 75.0 & 47.9 & 63.6 \\
\hline \multirow[t]{2}{*}{$\mathrm{p}$} & $(0.462)$ & $(0.009)$ & $(0.004)$ & $(0.020)$ & $(0.026)$ & $(0.030)$ & $(0.073)$ & $(0.227)$ & $(0.076)$ & $(0.000)$ & $(0.017)$ & $(0.000)$ \\
\hline & \multicolumn{12}{|c|}{ Mean annualized profit, \% per year } \\
\hline Carry trade & 0.3 & 0.1 & -0.4 & 0.1 & 0.7 & 0.4 & 0.2 & 0.0 & -1.2 & 4.5 & 0.8 & -1.4 \\
\hline $\mathrm{p}(=0)$ & $(0.425)$ & $(0.474)$ & $(0.626)$ & $(0.455)$ & $(0.146)$ & $(0.230)$ & $(0.382)$ & $(0.530)$ & $(0.998)$ & $(0.000)$ & $(0.264)$ & $(0.939)$ \\
\hline Model 3Y & 0.9 & 1.8 & 1.2 & 1.4 & 1.4 & 1.3 & 1.7 & 1.7 & -1.1 & 3.8 & -0.3 & 1.9 \\
\hline $\mathrm{p}(=0)$ & $(0.275)$ & $(0.081)$ & $(0.135)$ & $(0.058)$ & $(0.014)$ & $(0.013)$ & $(0.000)$ & $(0.000)$ & $(0.996)$ & $(0.000)$ & $(0.615)$ & $(0.013)$ \\
\hline $\mathrm{p}(=\mathrm{CT})$ & $(0.399)$ & $(0.176)$ & $(0.152)$ & $(0.156)$ & $(0.204)$ & $(0.123)$ & $(0.004)$ & $(0.000)$ & $(0.097)$ & $(0.993)$ & $(0.866)$ & $(0.030)$ \\
\hline Model 5Y & 1.3 & 1.3 & 1.4 & 1.3 & 1.3 & 1.3 & 1.7 & 1.5 & -1.1 & 4.2 & -0.3 & 1.9 \\
\hline $\mathrm{p}(=0)$ & $(0.184)$ & $(0.139)$ & $(0.100)$ & $(0.060)$ & $(0.021)$ & $(0.008)$ & $(0.000)$ & $(0.001)$ & $(0.996)$ & $(0.000)$ & $(0.615)$ & $(0.016)$ \\
\hline $\mathrm{p}(=\mathrm{CT})$ & $(0.333)$ & $(0.247)$ & $(0.131)$ & $(0.159)$ & $(0.235)$ & (0.098) & $(0.003)$ & $(0.001)$ & $(0.097)$ & $(0.885)$ & $(0.866)$ & $(0.032)$ \\
\hline Model 10Y & 1.8 & 1.5 & 1.3 & 1.2 & 1.2 & 1.1 & 1.2 & 1.1 & -1.2 & 4.5 & -2.1 & 1.9 \\
\hline $\mathrm{p}(=0)$ & $(0.096)$ & $(0.115)$ & $(0.128)$ & $(0.096)$ & $(0.032)$ & $(0.024)$ & $(0.009)$ & $(0.011)$ & (0.998) & $(0.000)$ & $(0.976)$ & $(0.015)$ \\
\hline $\mathrm{p}(=\mathrm{CT})$ & $(0.245)$ & $(0.216)$ & $(0.153)$ & $(0.205)$ & $(0.285)$ & $(0.177)$ & $(0.046)$ & $(0.012)$ & n.a. & $(0.453)$ & $(0.964)$ & $(0.031)$ \\
\hline Combined & 1.0 & 1.3 & 1.4 & 1.1 & 1.3 & 1.3 & 1.6 & 1.4 & -1.1 & 4.1 & -0.3 & 1.9 \\
\hline $\mathrm{p}(=0)$ & $(0.226)$ & $(0.150)$ & $(0.108)$ & $(0.098)$ & $(0.022)$ & $(0.009)$ & $(0.001)$ & $(0.001)$ & $(0.996)$ & $(0.000)$ & $(0.615)$ & $(0.016)$ \\
\hline $\mathrm{p}(=\mathrm{CT})$ & $(0.368)$ & $(0.256)$ & $(0.139)$ & $(0.205)$ & $(0.241)$ & $(0.103)$ & $(0.004)$ & $(0.001)$ & $(0.097)$ & $(0.964)$ & $(0.866)$ & (0.03 \\
\hline
\end{tabular}


Table A3 continued: Out-of-sample forecast evaluation, baseline results

AUD/USD

Full sample, different forecast horizons

Different samples, 36M forecast

\begin{tabular}{|c|c|c|c|c|c|c|c|c|c|c|c|c|}
\hline & \multicolumn{8}{|c|}{ 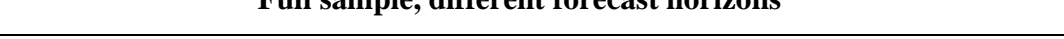 } & \multicolumn{4}{|c|}{ horizon } \\
\hline & $1 \mathrm{M}$ & $3 \mathrm{M}$ & $6 \mathrm{M}$ & $12 \mathrm{M}$ & $24 \mathrm{M}$ & $36 \mathrm{M}$ & $48 \mathrm{M}$ & $60 \mathrm{M}$ & $\begin{array}{c}1993- \\
99\end{array}$ & $\begin{array}{c}2000- \\
06\end{array}$ & $\begin{array}{c}2007- \\
10\end{array}$ & $\begin{array}{c}2011- \\
20\end{array}$ \\
\hline & \multicolumn{12}{|c|}{ Mean squared forecast error (MSFE), random walk without drift $=100$} \\
\hline $\begin{array}{l}\text { Forward } \\
p\end{array}$ & $\begin{array}{l}100.83 \\
(0.802) \\
\end{array}$ & $\begin{array}{l}102.40 \\
(0.819) \\
\end{array}$ & $\begin{array}{l}103.96 \\
(0.817) \\
\end{array}$ & $\begin{array}{r}107.47 \\
(0.918)\end{array}$ & $\begin{array}{l}111.08 \\
(0.960) \\
\end{array}$ & $\begin{array}{l}112.23 \\
(0.943) \\
\end{array}$ & $\begin{array}{l}110.49 \\
(0.893) \\
\end{array}$ & $\begin{array}{l}104.60 \\
(0.697) \\
\end{array}$ & $\begin{array}{r}80.56 \\
(0.115) \\
\end{array}$ & $\begin{array}{r}122.29 \\
(1.000) \\
\end{array}$ & $\begin{array}{r}169.72 \\
(1.000) \\
\end{array}$ & $\begin{array}{r}101.37 \\
(0.538) \\
\end{array}$ \\
\hline $\begin{array}{l}\text { Model 3Y } \\
\mathrm{p}(\mathrm{CW})\end{array}$ & $\begin{array}{r}99.16 \\
(0.036) \\
\end{array}$ & $\begin{array}{r}97.49 \\
(0.033) \\
\end{array}$ & $\begin{array}{r}94.95 \\
(0.019) \\
\end{array}$ & $\begin{array}{r}91.10 \\
(0.003) \\
\end{array}$ & $\begin{array}{r}85.40 \\
(0.000) \\
\end{array}$ & $\begin{array}{r}82.00 \\
(0.000) \\
\end{array}$ & $\begin{array}{r}78.12 \\
(0.000) \\
\end{array}$ & $\begin{array}{r}76.77 \\
(0.000) \\
\end{array}$ & $\begin{array}{r}84.77 \\
(0.012) \\
\end{array}$ & $\begin{array}{r}80.59 \\
(0.000) \\
\end{array}$ & $\begin{array}{r}156.67 \\
(0.999) \\
\end{array}$ & $\begin{array}{r}69.34 \\
(0.002) \\
\end{array}$ \\
\hline $\begin{array}{l}\text { Model 5Y } \\
\mathrm{p}(\mathrm{CW})\end{array}$ & $\begin{array}{r}98.93 \\
(0.017) \\
\end{array}$ & $\begin{array}{r}97.02 \\
(0.018) \\
\end{array}$ & $\begin{array}{r}94.33 \\
(0.011) \\
\end{array}$ & $\begin{array}{r}90.34 \\
(0.002) \\
\end{array}$ & $\begin{array}{r}84.75 \\
(0.000) \\
\end{array}$ & $\begin{array}{r}82.31 \\
(0.000) \\
\end{array}$ & $\begin{array}{r}79.87 \\
(0.000) \\
\end{array}$ & $\begin{array}{r}80.20 \\
(0.000) \\
\end{array}$ & $\begin{array}{r}89.41 \\
(0.061) \\
\end{array}$ & $\begin{array}{r}78.93 \\
(0.000) \\
\end{array}$ & $\begin{array}{r}165.06 \\
(0.999) \\
\end{array}$ & $\begin{array}{r}68.99 \\
(0.001) \\
\end{array}$ \\
\hline $\begin{array}{l}\text { Model 10Y } \\
\mathrm{p}(\mathrm{CW})\end{array}$ & $\begin{array}{r}99.04 \\
(0.027) \\
\end{array}$ & $\begin{array}{r}97.52 \\
(0.027) \\
\end{array}$ & $\begin{array}{r}95.61 \\
(0.019) \\
\end{array}$ & $\begin{array}{r}92.86 \\
(0.007) \\
\end{array}$ & $\begin{array}{r}90.31 \\
(0.002) \\
\end{array}$ & $\begin{array}{r}92.41 \\
(0.013) \\
\end{array}$ & $\begin{array}{r}93.96 \\
(0.028) \\
\end{array}$ & $\begin{array}{r}97.49 \\
(0.057) \\
\end{array}$ & $\begin{array}{r}100.64 \\
(0.187) \\
\end{array}$ & $\begin{array}{r}89.71 \\
(0.013) \\
\end{array}$ & $\begin{array}{l}187.65 \\
(1.000) \\
\end{array}$ & $\begin{array}{r}75.72 \\
(0.003) \\
\end{array}$ \\
\hline \multirow[t]{2}{*}{$\begin{array}{l}\text { Combined } \\
\mathrm{p}(\mathrm{CW})\end{array}$} & $\begin{array}{r}99.02 \\
(0.024) \\
\end{array}$ & $\begin{array}{r}97.28 \\
(0.024) \\
\end{array}$ & $\begin{array}{r}94.85 \\
(0.014) \\
\end{array}$ & $\begin{array}{r}91.24 \\
(0.003) \\
\end{array}$ & $\begin{array}{r}86.48 \\
(0.000) \\
\end{array}$ & $\begin{array}{r}85.08 \\
(0.001) \\
\end{array}$ & $\begin{array}{r}83.38 \\
(0.001) \\
\end{array}$ & $\begin{array}{r}84.10 \\
(0.001) \\
\end{array}$ & $\begin{array}{r}90.89 \\
(0.074) \\
\end{array}$ & $\begin{array}{r}82.40 \\
(0.000) \\
\end{array}$ & $\begin{array}{r}169.31 \\
(1.000) \\
\end{array}$ & $\begin{array}{r}71.13 \\
(0.002) \\
\end{array}$ \\
\hline & \multicolumn{12}{|c|}{ Correct sign prediction compared to the spot rate, \% } \\
\hline $\begin{array}{l}\text { Forward } \\
\mathrm{p}\end{array}$ & $\begin{array}{r}43.4 \\
(0.999) \\
\end{array}$ & $\begin{array}{r}41.7 \\
(1.000) \\
\end{array}$ & $\begin{array}{r}39.2 \\
(1.000) \\
\end{array}$ & $\begin{array}{r}38.2 \\
(1.000) \\
\end{array}$ & $\begin{array}{r}44.5 \\
(1.000) \\
\end{array}$ & $\begin{array}{r}48.6 \\
(1.000) \\
\end{array}$ & $\begin{array}{r}50.5 \\
(0.971) \\
\end{array}$ & $\begin{array}{r}52.5 \\
(0.141) \\
\end{array}$ & $\begin{array}{r}69.0 \\
\text { n.a. }\end{array}$ & $\begin{array}{r}22.6 \\
(1.000) \\
\end{array}$ & $\begin{array}{r}16.7 \\
\text { n.a. }\end{array}$ & $\begin{array}{r}66.4 \\
(0.000) \\
\end{array}$ \\
\hline $\begin{array}{l}\text { Model 3Y } \\
\mathrm{p}\end{array}$ & $\begin{array}{r}53.0 \\
(0.057) \\
\end{array}$ & $\begin{array}{r}53.6 \\
(0.027) \\
\end{array}$ & $\begin{array}{r}59.1 \\
(0.000) \\
\end{array}$ & $\begin{array}{r}59.0 \\
(0.000) \\
\end{array}$ & $\begin{array}{r}63.1 \\
(0.000) \\
\end{array}$ & $\begin{array}{r}65.4 \\
(0.000) \\
\end{array}$ & $\begin{array}{r}66.3 \\
(0.000) \\
\end{array}$ & $\begin{array}{r}67.0 \\
(0.000) \\
\end{array}$ & $\begin{array}{r}67.9 \\
(0.751) \\
\end{array}$ & $\begin{array}{r}82.1 \\
(0.000) \\
\end{array}$ & $\begin{array}{r}16.7 \\
\text { n.a. }\end{array}$ & $\begin{array}{r}72.7 \\
(0.000) \\
\end{array}$ \\
\hline $\begin{array}{l}\text { Model 5Y } \\
\mathrm{p}\end{array}$ & $\begin{array}{r}52.2 \\
(0.090) \\
\end{array}$ & $\begin{array}{r}53.6 \\
(0.014) \\
\end{array}$ & $\begin{array}{r}58.5 \\
(0.000) \\
\end{array}$ & $\begin{array}{r}58.1 \\
(0.000) \\
\end{array}$ & $\begin{array}{r}65.8 \\
(0.000) \\
\end{array}$ & $\begin{array}{r}65.7 \\
(0.000) \\
\end{array}$ & $\begin{array}{r}65.4 \\
(0.000) \\
\end{array}$ & $\begin{array}{r}63.4 \\
(0.000) \\
\end{array}$ & $\begin{array}{r}61.9 \\
(0.957) \\
\end{array}$ & $\begin{array}{r}90.5 \\
(0.000) \\
\end{array}$ & $\begin{array}{r}16.7 \\
\text { n.a. }\end{array}$ & $\begin{array}{r}71.8 \\
(0.000) \\
\end{array}$ \\
\hline $\begin{array}{l}\text { Model 10Y } \\
\mathrm{p}\end{array}$ & $\begin{array}{r}52.5 \\
(0.033) \\
\end{array}$ & $\begin{array}{r}52.8 \\
(0.016) \\
\end{array}$ & $\begin{array}{r}57.7 \\
(0.000) \\
\end{array}$ & $\begin{array}{r}56.7 \\
(0.000) \\
\end{array}$ & $\begin{array}{r}58.4 \\
(0.001) \\
\end{array}$ & $\begin{array}{r}56.0 \\
(0.088) \\
\end{array}$ & $\begin{array}{r}53.0 \\
(0.685) \\
\end{array}$ & $\begin{array}{r}49.2 \\
(0.954) \\
\end{array}$ & $\begin{array}{r}59.5 \\
(0.977) \\
\end{array}$ & $\begin{array}{r}59.5 \\
(0.000) \\
\end{array}$ & $\begin{array}{r}16.7 \\
\text { n.a. }\end{array}$ & $\begin{array}{r}68.2 \\
(0.000) \\
\end{array}$ \\
\hline $\begin{array}{l}\text { Combined } \\
\mathrm{p}\end{array}$ & $\begin{array}{r}52.2 \\
(0.079) \\
\end{array}$ & $\begin{array}{r}53.1 \\
(0.024) \\
\end{array}$ & $\begin{array}{r}58.5 \\
(0.000) \\
\end{array}$ & $\begin{array}{r}57.5 \\
(0.000) \\
\end{array}$ & $\begin{array}{r}65.2 \\
(0.000) \\
\end{array}$ & $\begin{array}{r}64.5 \\
(0.000) \\
\end{array}$ & $\begin{array}{r}62.5 \\
(0.000) \\
\end{array}$ & $\begin{array}{r}59.4 \\
(0.000) \\
\end{array}$ & $\begin{array}{r}61.9 \\
(0.957) \\
\end{array}$ & $\begin{array}{r}85.7 \\
(0.000) \\
\end{array}$ & $\begin{array}{r}16.7 \\
\text { n.a. }\end{array}$ & $\begin{array}{r}71.8 \\
(0.000) \\
\end{array}$ \\
\hline & \multicolumn{12}{|c|}{ Correct sign prediction compared to the forward rate, \% } \\
\hline $\begin{array}{l}\text { Model 3Y } \\
\mathrm{p}\end{array}$ & $\begin{array}{r}56.6 \\
(0.006) \\
\end{array}$ & $\begin{array}{r}56.9 \\
(0.006) \\
\end{array}$ & $\begin{array}{r}62.7 \\
(0.000) \\
\end{array}$ & $\begin{array}{r}67.2 \\
(0.000) \\
\end{array}$ & $\begin{array}{r}75.2 \\
(0.000) \\
\end{array}$ & $\begin{array}{r}74.9 \\
(0.000) \\
\end{array}$ & $\begin{array}{r}72.1 \\
(0.000) \\
\end{array}$ & $\begin{array}{r}68.6 \\
(0.000) \\
\end{array}$ & $\begin{array}{r}65.5 \\
(0.004) \\
\end{array}$ & $\begin{array}{r}83.3 \\
(0.000) \\
\end{array}$ & $\begin{array}{r}43.8 \\
(0.032) \\
\end{array}$ & $\begin{array}{r}89.1 \\
(0.000) \\
\end{array}$ \\
\hline $\begin{array}{l}\text { Model 5Y } \\
\mathrm{p}\end{array}$ & $\begin{array}{r}58.8 \\
(0.000) \\
\end{array}$ & $\begin{array}{r}57.2 \\
(0.002) \\
\end{array}$ & $\begin{array}{r}62.5 \\
(0.000) \\
\end{array}$ & $\begin{array}{r}68.7 \\
(0.000) \\
\end{array}$ & $\begin{array}{r}75.2 \\
(0.000) \\
\end{array}$ & $\begin{array}{r}76.5 \\
(0.000) \\
\end{array}$ & $\begin{array}{r}71.4 \\
(0.000) \\
\end{array}$ & $\begin{array}{r}65.3 \\
(0.000) \\
\end{array}$ & $\begin{array}{r}59.5 \\
(0.144) \\
\end{array}$ & $\begin{array}{r}92.9 \\
(0.000) \\
\end{array}$ & $\begin{array}{r}39.6 \\
(0.047) \\
\end{array}$ & $\begin{array}{r}92.7 \\
(0.000) \\
\end{array}$ \\
\hline $\begin{array}{l}\text { Model 10Y } \\
\mathrm{p}\end{array}$ & $\begin{array}{r}59.1 \\
(0.000) \\
\end{array}$ & $\begin{array}{r}59.4 \\
(0.000) \\
\end{array}$ & $\begin{array}{r}66.1 \\
(0.000) \\
\end{array}$ & $\begin{array}{r}69.2 \\
(0.000) \\
\end{array}$ & $\begin{array}{r}71.1 \\
(0.000) \\
\end{array}$ & $\begin{array}{r}67.3 \\
(0.000) \\
\end{array}$ & $\begin{array}{r}66.3 \\
(0.000) \\
\end{array}$ & $\begin{array}{r}56.1 \\
(0.015) \\
\end{array}$ & $\begin{array}{r}48.8 \\
(0.757) \\
\end{array}$ & $\begin{array}{r}84.5 \\
(0.000) \\
\end{array}$ & $\begin{array}{r}39.6 \\
(0.047) \\
\end{array}$ & $\begin{array}{r}80.0 \\
(0.000) \\
\end{array}$ \\
\hline $\begin{array}{l}\text { Combined } \\
\mathrm{p}\end{array}$ & $\begin{array}{r}59.1 \\
(0.000) \\
\end{array}$ & $\begin{array}{r}57.5 \\
(0.001) \\
\end{array}$ & $\begin{array}{r}63.0 \\
(0.000) \\
\end{array}$ & $\begin{array}{r}69.5 \\
(0.000) \\
\end{array}$ & $\begin{array}{r}74.3 \\
(0.000) \\
\end{array}$ & $\begin{array}{r}75.5 \\
(0.000) \\
\end{array}$ & $\begin{array}{r}71.1 \\
(0.000) \\
\end{array}$ & $\begin{array}{r}63.7 \\
(0.000) \\
\end{array}$ & $\begin{array}{r}57.1 \\
(0.282) \\
\end{array}$ & $\begin{array}{r}92.9 \\
(0.000) \\
\end{array}$ & $\begin{array}{r}39.6 \\
(0.047) \\
\end{array}$ & $\begin{array}{r}91.8 \\
(0.000) \\
\end{array}$ \\
\hline & \multicolumn{12}{|c|}{ Mean annualized profit, \% per year } \\
\hline $\begin{array}{l}\text { Carry trade } \\
\mathrm{p}(=0)\end{array}$ & $\begin{array}{r}5.2 \\
(0.009) \\
\end{array}$ & $\begin{array}{r}5.5 \\
(0.003) \\
\end{array}$ & $\begin{array}{r}5.2 \\
(0.001) \\
\end{array}$ & $\begin{array}{r}4.6 \\
(0.000) \\
\end{array}$ & $\begin{array}{r}3.2 \\
(0.001) \\
\end{array}$ & $\begin{array}{r}2.6 \\
(0.001) \\
\end{array}$ & $\begin{array}{r}2.1 \\
(0.002) \\
\end{array}$ & $\begin{array}{r}1.6 \\
(0.007) \\
\end{array}$ & $\begin{array}{r}0.4 \\
(0.304) \\
\end{array}$ & $\begin{array}{r}6.4 \\
(0.000) \\
\end{array}$ & $\begin{array}{r}4.7 \\
(0.000) \\
\end{array}$ & $\begin{array}{r}0.6 \\
(0.335) \\
\end{array}$ \\
\hline $\begin{array}{l}\text { Model 3Y } \\
\mathrm{p}(=0) \\
\mathrm{p}(=\mathrm{CT})\end{array}$ & $\begin{array}{r}4.2 \\
(0.027) \\
(0.693) \\
\end{array}$ & $\begin{array}{r}4.1 \\
(0.020) \\
(0.784) \\
\end{array}$ & $\begin{array}{r}4.4 \\
(0.006) \\
(0.716) \\
\end{array}$ & $\begin{array}{r}4.7 \\
(0.000) \\
(0.482) \\
\end{array}$ & $\begin{array}{r}4.7 \\
(0.000) \\
(0.037) \\
\end{array}$ & $\begin{array}{r}3.9 \\
(0.000) \\
(0.015) \\
\end{array}$ & $\begin{array}{r}3.2 \\
(0.000) \\
(0.048) \\
\end{array}$ & $\begin{array}{r}2.2 \\
(0.000) \\
(0.185) \\
\end{array}$ & $\begin{array}{r}1.3 \\
(0.053) \\
(0.087) \\
\end{array}$ & $\begin{array}{r}7.4 \\
(0.000) \\
(0.001) \\
\end{array}$ & $\begin{array}{r}-0.6 \\
(0.656) \\
(1.000) \\
\end{array}$ & $\begin{array}{r}5.5 \\
(0.000) \\
(0.000) \\
\end{array}$ \\
\hline $\begin{array}{l}\text { Model 5Y } \\
\mathrm{p}(=0) \\
\mathrm{p}(=\mathrm{CT})\end{array}$ & $\begin{array}{r}5.1 \\
(0.011) \\
(0.516) \\
\end{array}$ & $\begin{array}{r}4.6 \\
(0.009) \\
(0.687) \\
\end{array}$ & $\begin{array}{r}4.8 \\
(0.002) \\
(0.603) \\
\end{array}$ & $\begin{array}{r}5.3 \\
(0.000) \\
(0.301) \\
\end{array}$ & $\begin{array}{r}5.1 \\
(0.000) \\
(0.010) \\
\end{array}$ & $\begin{array}{r}3.9 \\
(0.000) \\
(0.020) \\
\end{array}$ & $\begin{array}{r}3.0 \\
(0.000) \\
(0.094) \\
\end{array}$ & $\begin{array}{r}1.8 \\
(0.002) \\
(0.402) \\
\end{array}$ & $\begin{array}{r}0.5 \\
(0.215) \\
(0.445) \\
\end{array}$ & $\begin{array}{r}8.4 \\
(0.000) \\
(0.000) \\
\end{array}$ & $\begin{array}{r}-1.1 \\
(0.770) \\
(1.000) \\
\end{array}$ & $\begin{array}{r}5.5 \\
(0.000) \\
(0.000) \\
\end{array}$ \\
\hline $\begin{array}{l}\text { Model 10Y } \\
\mathrm{p}(=0) \\
\mathrm{p}(=\mathrm{CT})\end{array}$ & $\begin{array}{r}5.9 \\
(0.003) \\
(0.356) \\
\end{array}$ & $\begin{array}{r}5.6 \\
(0.002) \\
(0.468) \\
\end{array}$ & $\begin{array}{r}5.6 \\
(0.001) \\
(0.410) \\
\end{array}$ & $\begin{array}{r}5.2 \\
(0.000) \\
(0.338) \\
\end{array}$ & $\begin{array}{r}4.8 \\
(0.000) \\
(0.040) \\
\end{array}$ & $\begin{array}{r}3.0 \\
(0.000) \\
(0.321) \\
\end{array}$ & $\begin{array}{r}2.1 \\
(0.002) \\
(0.517) \\
\end{array}$ & $\begin{array}{r}0.9 \\
(0.094) \\
(0.819) \\
\end{array}$ & $\begin{array}{r}-0.5 \\
(0.744) \\
(0.777) \\
\end{array}$ & $\begin{array}{r}6.2 \\
(0.000) \\
(0.579) \\
\end{array}$ & $\begin{array}{r}-1.1 \\
(0.770) \\
(1.000) \\
\end{array}$ & $\begin{array}{r}5.2 \\
(0.000) \\
(0.000) \\
\end{array}$ \\
\hline $\begin{array}{l}\text { Combined } \\
\mathrm{p}(=0) \\
\mathrm{p}(=\mathrm{CT})\end{array}$ & $\begin{array}{r}5.3 \\
(0.010) \\
(0.469) \\
\end{array}$ & $\begin{array}{r}4.8 \\
(0.007) \\
(0.643) \\
\end{array}$ & $\begin{array}{r}5.0 \\
(0.002) \\
(0.569) \\
\end{array}$ & $\begin{array}{r}5.3 \\
(0.000) \\
(0.287) \\
\end{array}$ & $\begin{array}{r}5.0 \\
(0.000) \\
(0.015) \\
\end{array}$ & $\begin{array}{r}3.9 \\
(0.000) \\
(0.031) \\
\end{array}$ & $\begin{array}{r}2.9 \\
(0.000) \\
(0.126) \\
\end{array}$ & $\begin{array}{r}1.7 \\
(0.004) \\
(0.484) \\
\end{array}$ & $\begin{array}{r}0.2 \\
(0.381) \\
(0.590) \\
\end{array}$ & $\begin{array}{r}8.4 \\
(0.000) \\
(0.000) \\
\end{array}$ & $\begin{array}{r}-1.1 \\
(0.770) \\
(1.000) \\
\end{array}$ & $\begin{array}{r}5.5 \\
(0.000) \\
(0.000) \\
\end{array}$ \\
\hline
\end{tabular}


Table A3 continued: Out-of-sample forecast evaluation, baseline results

NZD/USD

Full sample, different forecast horizons

Different samples, 36M forecast

\section{NZD/USD}

\begin{tabular}{llllllllllccc}
\hline $1 \mathrm{M}$ & $3 \mathrm{M}$ & $6 \mathrm{M}$ & $12 \mathrm{M}$ & $24 \mathrm{M}$ & $36 \mathrm{M}$ & $48 \mathrm{M}$ & $60 \mathrm{M}$ & & $\begin{array}{c}1993- \\
99\end{array}$ & $\begin{array}{c}2000- \\
06\end{array}$ & $\begin{array}{c}2007- \\
10\end{array}$ & $\begin{array}{c}2011- \\
20\end{array}$
\end{tabular}

Mean squared forecast error (MSFE), random walk without drift $=100$

\begin{tabular}{|c|c|c|c|c|c|c|c|c|c|c|c|c|}
\hline $\begin{array}{l}\text { Forward } \\
\mathrm{p}\end{array}$ & $\begin{array}{l}100.78 \\
(0.769) \\
\end{array}$ & $\begin{array}{l}102.15 \\
(0.764) \\
\end{array}$ & $\begin{array}{l}103.58 \\
(0.780) \\
\end{array}$ & $\begin{array}{l}107.68 \\
(0.900) \\
\end{array}$ & $\begin{array}{l}114.44 \\
(0.983) \\
\end{array}$ & $\begin{array}{l}119.58 \\
(0.995) \\
\end{array}$ & $\begin{array}{r}123.04 \\
(0.997) \\
\end{array}$ & $\begin{array}{l}125.75 \\
(0.996) \\
\end{array}$ & $\begin{array}{l}108.17 \\
(0.737) \\
\end{array}$ & $\begin{array}{l}116.67 \\
(0.991) \\
\end{array}$ & $\begin{array}{l}170.91 \\
(0.984) \\
\end{array}$ & $\begin{array}{l}131.10 \\
(0.929) \\
\end{array}$ \\
\hline $\begin{array}{l}\text { Model 3Y } \\
\mathrm{p}(\mathrm{CW})\end{array}$ & $\begin{array}{l}101.64 \\
(0.205) \\
\end{array}$ & $\begin{array}{l}104.59 \\
(0.194) \\
\end{array}$ & $\begin{array}{l}104.31 \\
(0.100) \\
\end{array}$ & $\begin{array}{l}100.73 \\
(0.029) \\
\end{array}$ & $\begin{array}{r}88.81 \\
(0.002) \\
\end{array}$ & $\begin{array}{r}79.77 \\
(0.000) \\
\end{array}$ & $\begin{array}{r}74.04 \\
(0.000) \\
\end{array}$ & $\begin{array}{r}75.19 \\
(0.000) \\
\end{array}$ & $\begin{array}{r}97.66 \\
(0.044) \\
\end{array}$ & $\begin{array}{r}50.58 \\
(0.000) \\
\end{array}$ & $\begin{array}{r}266.69 \\
(0.574) \\
\end{array}$ & $\begin{array}{r}111.82 \\
(0.032) \\
\end{array}$ \\
\hline $\begin{array}{l}\text { Model 5Y } \\
\mathrm{p}(\mathrm{CW})\end{array}$ & $\begin{array}{l}100.75 \\
(0.104) \\
\end{array}$ & $\begin{array}{r}102.65 \\
(0.125) \\
\end{array}$ & $\begin{array}{l}102.86 \\
(0.085) \\
\end{array}$ & $\begin{array}{r}102.33 \\
(0.042) \\
\end{array}$ & $\begin{array}{r}98.93 \\
(0.010) \\
\end{array}$ & $\begin{array}{r}98.16 \\
(0.006) \\
\end{array}$ & $\begin{array}{r}98.24 \\
(0.004) \\
\end{array}$ & $\begin{array}{l}102.22 \\
(0.004) \\
\end{array}$ & $\begin{array}{r}175.42 \\
(0.598) \\
\end{array}$ & $\begin{array}{r}59.61 \\
(0.000) \\
\end{array}$ & $\begin{array}{r}241.60 \\
(0.554) \\
\end{array}$ & $\begin{array}{r}103.64 \\
(0.022) \\
\end{array}$ \\
\hline $\begin{array}{l}\text { Model 10Y } \\
\mathrm{p}(\mathrm{CW})\end{array}$ & $\begin{array}{l}100.52 \\
(0.094) \\
\end{array}$ & $\begin{array}{l}102.18 \\
(0.131) \\
\end{array}$ & $\begin{array}{l}103.46 \\
(0.123) \\
\end{array}$ & $\begin{array}{l}106.16 \\
(0.120) \\
\end{array}$ & $\begin{array}{l}110.81 \\
(0.111) \\
\end{array}$ & $\begin{array}{l}118.71 \\
(0.193) \\
\end{array}$ & $\begin{array}{l}123.70 \\
(0.218) \\
\end{array}$ & $\begin{array}{l}128.65 \\
(0.170) \\
\end{array}$ & $\begin{array}{l}253.89 \\
(0.951) \\
\end{array}$ & $\begin{array}{r}76.01 \\
(0.000) \\
\end{array}$ & $\begin{array}{l}190.78 \\
(0.585) \\
\end{array}$ & $\begin{array}{r}88.59 \\
(0.009) \\
\end{array}$ \\
\hline $\begin{array}{l}\text { Combined } \\
\mathrm{p}(\mathrm{CW})\end{array}$ & $\begin{array}{l}100.72 \\
(0.126) \\
\end{array}$ & $\begin{array}{l}102.44 \\
(0.143) \\
\end{array}$ & $\begin{array}{l}102.44 \\
(0.093) \\
\end{array}$ & $\begin{array}{l}101.41 \\
(0.045) \\
\end{array}$ & $\begin{array}{r}97.16 \\
(0.009) \\
\end{array}$ & $\begin{array}{r}96.08 \\
(0.006) \\
\end{array}$ & $\begin{array}{r}95.58 \\
(0.004) \\
\end{array}$ & $\begin{array}{r}98.43 \\
(0.003) \\
\end{array}$ & $\begin{array}{r}168.30 \\
(0.577) \\
\end{array}$ & $\begin{array}{r}60.52 \\
(0.000) \\
\end{array}$ & $\begin{array}{l}230.08 \\
(0.570) \\
\end{array}$ & $\begin{array}{r}99.66 \\
(0.020) \\
\end{array}$ \\
\hline
\end{tabular}

$\begin{array}{lllllllll}\mathrm{p}(\mathrm{CW}) & (0.126) & (0.143) & (0.093) & (0.045) & (0.009) & (0.006) & (0.004) & (0.003)\end{array}$

\begin{tabular}{|c|c|c|c|c|c|c|c|c|c|c|c|c|}
\hline & \multicolumn{12}{|c|}{ prediction compared to the spot rate, $\%$} \\
\hline Model 3Y & 49.7 & 49.7 & 52.1 & 52.1 & 58.7 & 58.4 & 59.0 & 63.0 & 54.8 & 67.9 & 37.5 & 62.7 \\
\hline Model 5Y & 48.3 & 48.9 & 52.1 & 52.1 & 59.6 & 60.6 & 57.1 & 55.4 & 50.0 & 81.0 & 37.5 & 62.7 \\
\hline $\mathrm{p}$ & $(0.252)$ & $(0.285)$ & $(0.015)$ & $(0.005)$ & $(0.000)$ & $(0.000)$ & $(0.000)$ & $(0.000)$ & n.a. & $(0.000)$ & n.a. & $(0.000)$ \\
\hline Combined & 48.6 & 48.9 & 51.5 & 51.0 & 59.6 & 59.6 & 57.5 & 56.8 & 50.0 & 77.4 & 37.5 & 62.7 \\
\hline \multirow[t]{2}{*}{$\mathrm{p}$} & $(0.225)$ & $(0.294)$ & $(0.033)$ & $(0.032)$ & $(0.000)$ & $(0.000)$ & $(0.000)$ & $(0.000)$ & n.a. & $(0.000)$ & n.a. & $(0.000)$ \\
\hline & \multicolumn{12}{|c|}{ Correct sign prediction compared to the forward rate, \% } \\
\hline Model 3Y & 49.7 & 50.3 & 50.4 & 54.1 & 55.2 & 59.0 & 66.3 & 68.0 & 66.7 & 72.6 & 20.8 & 60.0 \\
\hline $\mathrm{p}$ & $(0.200)$ & $(0.181)$ & $(0.094)$ & $(0.003)$ & $(0.001)$ & $(0.000)$ & $(0.000)$ & $(0.000)$ & $(0.000)$ & $(0.000)$ & $(0.312)$ & $(0.000)$ \\
\hline $\mathrm{p}$ & $(0.003)$ & $(0.002)$ & $(0.000)$ & $(0.000)$ & $(0.000)$ & $(0.000)$ & $(0.000)$ & $(0.000)$ & $(0.472)$ & $(0.000)$ & $(0.026)$ & $(0.000)$ \\
\hline Combined & 48.9 & 50.3 & 49.6 & 51.9 & 54.0 & 58.1 & 63.5 & 67.7 & 42.9 & 78.6 & 29.2 & 67.3 \\
\hline \multirow[t]{2}{*}{$\mathrm{p}$} & $(0.163)$ & $(0.091)$ & $(0.059)$ & $(0.011)$ & $(0.001)$ & $(0.000)$ & $(0.000)$ & $(0.000)$ & $(0.012)$ & $(0.000)$ & $(0.126)$ & $(0.000)$ \\
\hline & \multicolumn{12}{|c|}{ Mean annualized profit, \% per year } \\
\hline Carry trade & 3.7 & 3.9 & 4.3 & 3.7 & 3.3 & 3.0 & 2.9 & 2.7 & 2.3 & 4.6 & 2.7 & 2.5 \\
\hline $\mathrm{p}(=0)$ & $(0.052)$ & $(0.031)$ & $(0.011)$ & $(0.008)$ & $(0.002)$ & $(0.001)$ & $(0.000)$ & $(0.000)$ & $(0.042)$ & $(0.025)$ & $(0.007)$ & $(0.017)$ \\
\hline Model 3Y & 0.5 & 0.0 & 1.5 & 2.2 & 2.2 & 2.3 & 2.9 & 2.6 & 2.1 & 7.4 & -2.3 & 0.8 \\
\hline $\mathrm{p}(=0)$ & $(0.400)$ & $(0.494)$ & $(0.182)$ & $(0.063)$ & $(0.024)$ & $(0.006)$ & $(0.000)$ & $(0.000)$ & $(0.041)$ & $(0.000)$ & $(0.990)$ & $(0.226)$ \\
\hline $\mathrm{p}(=\mathrm{CT})$ & $(0.866)$ & $(0.939)$ & $(0.879)$ & $(0.761)$ & $(0.788)$ & $(0.742)$ & $(0.480)$ & $(0.567)$ & $(0.553)$ & $(0.013)$ & $(0.992)$ & $(0.865)$ \\
\hline Model 5Y & -0.4 & -0.3 & 0.5 & 1.2 & 1.9 & 2.0 & 2.4 & 2.2 & -1.5 & 8.4 & -1.4 & 1.6 \\
\hline $\mathrm{p}(=0)$ & $(0.529)$ & $(0.461)$ & $(0.457)$ & $(0.144)$ & $(0.027)$ & (0.008) & $(0.001)$ & $(0.000)$ & $(0.871)$ & $(0.000)$ & $(0.938)$ & $(0.009)$ \\
\hline$p(=\mathrm{CT})$ & $(0.922)$ & $(0.934)$ & $(0.970)$ & $(0.870)$ & $(0.801)$ & $(0.768)$ & $(0.652)$ & $(0.652)$ & $(0.929)$ & $(0.001)$ & $(0.986)$ & $(0.580)$ \\
\hline
\end{tabular}


Table A3 continued: Out-of-sample forecast evaluation, baseline results

NOK/USD

Full sample, different forecast horizons

Different samples, 36M forecast

\section{NOK/USD}

\begin{tabular}{llllllll}
\hline $1 \mathrm{M}$ & $3 \mathrm{M}$ & $6 \mathrm{M}$ & $12 \mathrm{M}$ & $24 \mathrm{M}$ & $36 \mathrm{M}$ & $48 \mathrm{M}$ & $60 \mathrm{M}$ \\
\hline
\end{tabular}

Mean squared forecast error (MSFE), random walk without drift $=100$

\begin{tabular}{cccc}
\multicolumn{4}{c}{ horizon } \\
\hline $1993-$ & $2000-$ & $2007-$ & $2011-$ \\
99 & 06 & 10 & 20 \\
\hline
\end{tabular}

\begin{tabular}{lrrrrrrrrrrrrr}
\multicolumn{10}{c}{ Mean squared forecast error (MSFE), random walk without drift = 100 } \\
\hline Forward & 99.46 & 99.84 & 100.52 & 102.51 & 106.66 & 111.25 & 111.17 & 106.04 & 111.58 & 144.75 & 88.99 & 87.92 \\
$\mathrm{p}$ & $(0.359)$ & $(0.478)$ & $(0.549)$ & $(0.669)$ & $(0.846)$ & $(0.945)$ & $(0.945)$ & $(0.792)$ & $(0.772)$ & $(1.000)$ & $(0.112)$ & $(0.018)$ \\
\hline Model 3Y & 99.82 & 99.10 & 97.71 & 94.05 & 85.59 & 74.92 & 66.05 & 62.38 & 51.10 & 60.45 & 220.13 & 70.59 \\
$\mathrm{p}(\mathrm{CW})$ & $(0.160)$ & $(0.127)$ & $(0.094)$ & $(0.024)$ & $(0.001)$ & $(0.000)$ & $(0.000)$ & $(0.000)$ & $(0.000)$ & $(0.000)$ & $(0.955)$ & $(0.001)$ \\
\hline Model 5Y & 99.56 & 98.77 & 97.19 & 93.21 & 84.87 & 75.30 & 66.73 & 63.87 & 56.92 & 59.09 & 237.74 & 67.55 \\
$\mathrm{p}(\mathrm{CW})$ & $(0.106)$ & $(0.104)$ & $(0.076)$ & $(0.019)$ & $(0.001)$ & $(0.000)$ & $(0.000)$ & $(0.000)$ & $(0.000)$ & $(0.000)$ & $(0.964)$ & $(0.000)$ \\
\hline Model 10Y & 99.54 & 99.07 & 97.73 & 94.68 & 88.69 & 81.30 & 75.06 & 74.19 & 70.61 & 68.30 & 272.71 & 63.35 \\
$\mathrm{p}$ (CW) & $(0.106)$ & $(0.121)$ & $(0.083)$ & $(0.028)$ & $(0.003)$ & $(0.000)$ & $(0.000)$ & $(0.000)$ & $(0.004)$ & $(0.000)$ & $(0.978)$ & $(0.000)$ \\
\hline Combined & 99.61 & 98.90 & 97.39 & 93.69 & 85.87 & 76.50 & 68.56 & 66.09 & 58.79 & 61.72 & 242.79 & 66.70 \\
$\mathrm{p}$ (CW) & $(0.119)$ & $(0.115)$ & $(0.082)$ & $(0.022)$ & $(0.001)$ & $(0.000)$ & $(0.000)$ & $(0.000)$ & $(0.000)$ & $(0.000)$ & $(0.968)$ & $(0.000)$ \\
\hline
\end{tabular}

\begin{tabular}{llllllllll}
$\mathrm{p}(\mathrm{CW})$ & $(0.119)$ & $(0.115)$ & $(0.082)$ & $(0.022)$ & $(0.001)$ & $(0.000)$ & $(0.000)$ & $(0.000)$ & $(0.0)$ \\
\hline & Correct sign prediction compared to the spot rate, \%
\end{tabular}

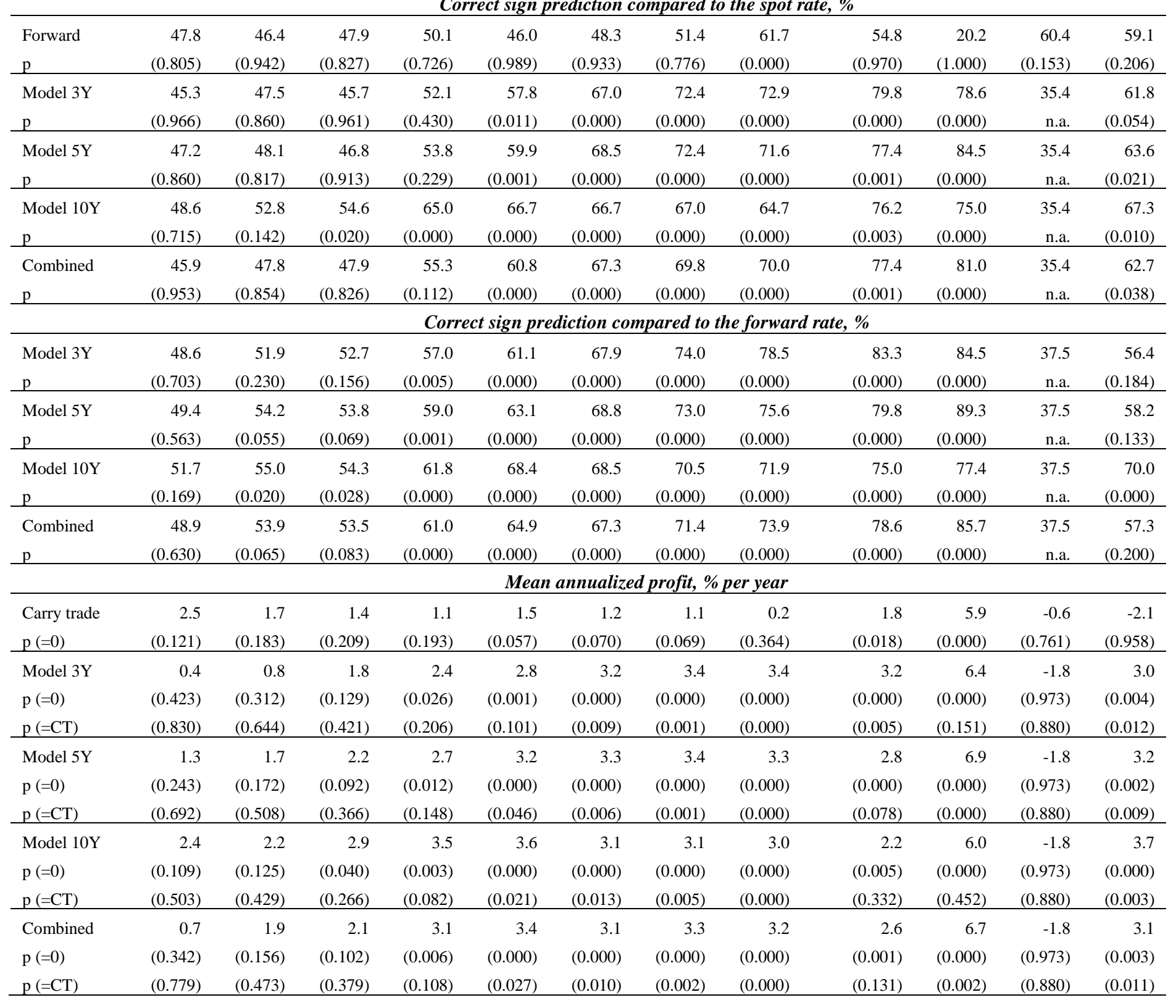


Table A3 continued: Out-of-sample forecast evaluation, baseline results

SEK/USD

Full sample, different forecast horizons

Different samples, $36 \mathrm{M}$ forecast

\section{SEK/USD}

\begin{tabular}{|c|c|c|c|c|c|c|c|c|c|c|c|}
\hline \multicolumn{8}{|c|}{ 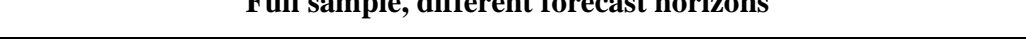 } & \multicolumn{4}{|c|}{ horizon } \\
\hline $1 \mathrm{M}$ & $3 \mathrm{M}$ & $6 \mathrm{M}$ & $12 \mathrm{M}$ & $24 \mathrm{M}$ & $36 \mathrm{M}$ & $48 \mathrm{M}$ & $60 \mathrm{M}$ & $\begin{array}{c}1993- \\
99\end{array}$ & $\begin{array}{c}2000- \\
06\end{array}$ & $\begin{array}{c}2007- \\
10\end{array}$ & $\begin{array}{c}2011- \\
20\end{array}$ \\
\hline
\end{tabular}

Mean squared forecast error (MSFE), random walk without drift $=100$

\begin{tabular}{|c|c|c|c|c|c|c|c|c|c|c|c|c|}
\hline $\begin{array}{l}\text { Forward } \\
\mathrm{p}\end{array}$ & $\begin{array}{r}99.45 \\
(0.383) \\
\end{array}$ & $\begin{array}{r}99.03 \\
(0.405) \\
\end{array}$ & $\begin{array}{r}99.20 \\
(0.442) \\
\end{array}$ & $\begin{array}{r}98.91 \\
(0.441) \\
\end{array}$ & $\begin{array}{r}99.91 \\
(0.495) \\
\end{array}$ & $\begin{array}{r}94.29 \\
(0.240) \\
\end{array}$ & $\begin{array}{r}93.23 \\
(0.151) \\
\end{array}$ & $\begin{array}{r}87.13 \\
(0.030) \\
\end{array}$ & $\begin{array}{r}56.57 \\
(0.009) \\
\end{array}$ & $\begin{array}{l}118.66 \\
(1.000) \\
\end{array}$ & $\begin{array}{r}98.30 \\
(0.464) \\
\end{array}$ & $\begin{array}{l}101.59 \\
(0.621) \\
\end{array}$ \\
\hline $\begin{array}{l}\text { Model 3Y } \\
\mathrm{p}(\mathrm{CW})\end{array}$ & $\begin{array}{l}102.17 \\
(0.554) \\
\end{array}$ & $\begin{array}{r}100.41 \\
(0.163) \\
\end{array}$ & $\begin{array}{r}96.13 \\
(0.058) \\
\end{array}$ & $\begin{array}{r}95.53 \\
(0.031) \\
\end{array}$ & $\begin{array}{r}94.11 \\
(0.008) \\
\end{array}$ & $\begin{array}{r}91.87 \\
(0.002) \\
\end{array}$ & $\begin{array}{r}81.60 \\
(0.000) \\
\end{array}$ & $\begin{array}{r}76.75 \\
(0.000) \\
\end{array}$ & $\begin{array}{r}92.68 \\
(0.017) \\
\end{array}$ & $\begin{array}{r}96.49 \\
(0.135) \\
\end{array}$ & $\begin{array}{r}159.42 \\
(0.659) \\
\end{array}$ & $\begin{array}{r}71.75 \\
(0.002) \\
\end{array}$ \\
\hline $\begin{array}{l}\text { Model 5Y } \\
\mathrm{p}(\mathrm{CW})\end{array}$ & $\begin{array}{l}100.81 \\
(0.276) \\
\end{array}$ & $\begin{array}{r}99.94 \\
(0.107) \\
\end{array}$ & $\begin{array}{r}94.42 \\
(0.014) \\
\end{array}$ & $\begin{array}{r}88.40 \\
(0.003) \\
\end{array}$ & $\begin{array}{r}78.60 \\
(0.000) \\
\end{array}$ & $\begin{array}{r}79.88 \\
(0.000) \\
\end{array}$ & $\begin{array}{r}73.87 \\
(0.000) \\
\end{array}$ & $\begin{array}{r}74.68 \\
(0.000) \\
\end{array}$ & $\begin{array}{r}95.89 \\
(0.131) \\
\end{array}$ & $\begin{array}{r}53.77 \\
(0.000) \\
\end{array}$ & $\begin{array}{l}322.55 \\
(0.777) \\
\end{array}$ & $\begin{array}{r}58.12 \\
(0.001) \\
\end{array}$ \\
\hline $\begin{array}{l}\text { Model 10Y } \\
\mathrm{p}(\mathrm{CW})\end{array}$ & $\begin{array}{r}99.07 \\
(0.042) \\
\end{array}$ & $\begin{array}{r}97.58 \\
(0.034) \\
\end{array}$ & $\begin{array}{r}94.87 \\
(0.018) \\
\end{array}$ & $\begin{array}{r}90.41 \\
(0.003) \\
\end{array}$ & $\begin{array}{r}85.00 \\
(0.000) \\
\end{array}$ & $\begin{array}{r}92.60 \\
(0.003) \\
\end{array}$ & $\begin{array}{r}95.20 \\
(0.005) \\
\end{array}$ & $\begin{array}{r}99.19 \\
(0.010) \\
\end{array}$ & $\begin{array}{l}116.75 \\
(0.718) \\
\end{array}$ & $\begin{array}{r}69.96 \\
(0.000) \\
\end{array}$ & $\begin{array}{l}286.18 \\
(0.763) \\
\end{array}$ & $\begin{array}{r}63.79 \\
(0.001) \\
\end{array}$ \\
\hline $\begin{array}{l}\text { Combined } \\
\mathrm{p}(\mathrm{CW})\end{array}$ & $\begin{array}{r}100.24 \\
(0.265) \\
\end{array}$ & $\begin{array}{r}98.43 \\
(0.061) \\
\end{array}$ & $\begin{array}{r}93.94 \\
(0.015) \\
\end{array}$ & $\begin{array}{r}89.81 \\
(0.004) \\
\end{array}$ & $\begin{array}{r}83.69 \\
(0.000) \\
\end{array}$ & $\begin{array}{r}85.14 \\
(0.000) \\
\end{array}$ & $\begin{array}{r}80.06 \\
(0.000) \\
\end{array}$ & $\begin{array}{r}79.98 \\
(0.000) \\
\end{array}$ & $\begin{array}{r}99.60 \\
(0.207) \\
\end{array}$ & $\begin{array}{r}70.53 \\
(0.000) \\
\end{array}$ & $\begin{array}{r}247.33 \\
(0.751) \\
\end{array}$ & $\begin{array}{r}61.48 \\
(0.001) \\
\end{array}$ \\
\hline
\end{tabular}

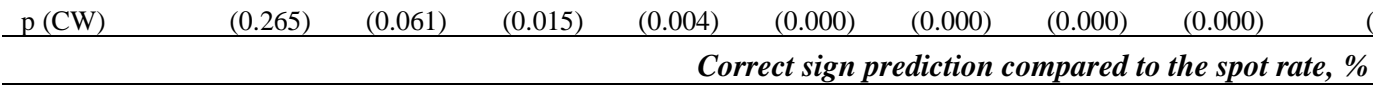

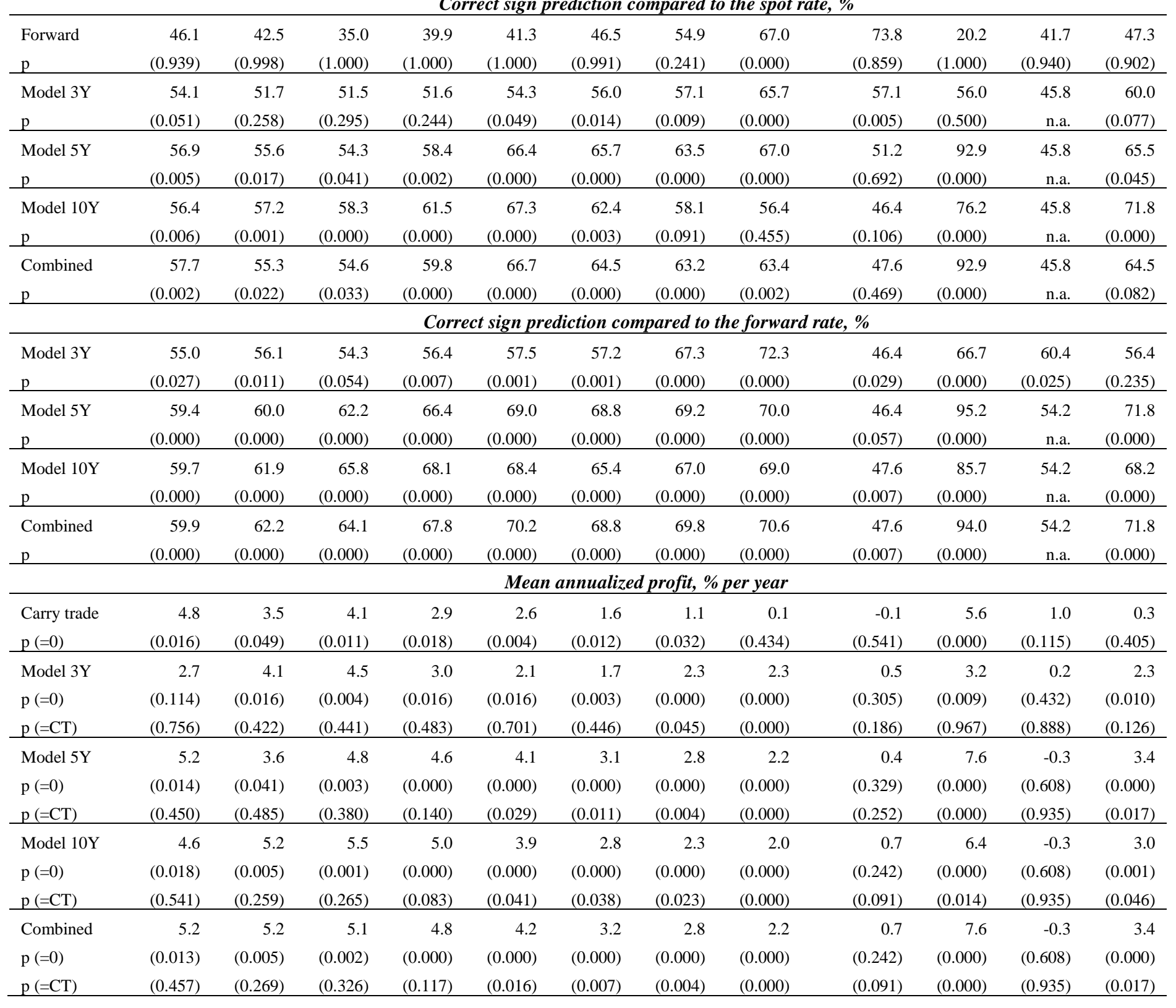


Table A3 continued: Out-of-sample forecast evaluation, baseline results

GBP/DEM

Full sample, different forecast horizons

Different samples, 36M forecast

\begin{tabular}{|c|c|c|c|c|c|c|c|c|c|c|c|c|}
\hline & \multicolumn{8}{|c|}{ 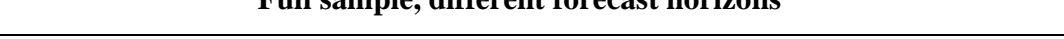 } & \multicolumn{4}{|c|}{ horizon } \\
\hline & $1 \mathrm{M}$ & $3 \mathrm{M}$ & $6 \mathrm{M}$ & $12 \mathrm{M}$ & $24 \mathrm{M}$ & $36 \mathrm{M}$ & $48 \mathrm{M}$ & $60 \mathrm{M}$ & $\begin{array}{c}1993- \\
99\end{array}$ & $\begin{array}{c}2000- \\
06\end{array}$ & $\begin{array}{c}2007- \\
10\end{array}$ & $\begin{array}{c}2011- \\
20\end{array}$ \\
\hline & \multicolumn{12}{|c|}{ Mean squared forecast error (MSFE), random walk without drift $=100$} \\
\hline $\begin{array}{l}\text { Forward } \\
\mathrm{p}\end{array}$ & $\begin{array}{r}101.19 \\
(0.931) \\
\end{array}$ & $\begin{array}{l}102.85 \\
(0.905) \\
\end{array}$ & $\begin{array}{l}104.67 \\
(0.922) \\
\end{array}$ & $\begin{array}{l}106.65 \\
(0.923) \\
\end{array}$ & $\begin{array}{l}108.18 \\
(0.885) \\
\end{array}$ & $\begin{array}{l}104.02 \\
(0.681) \\
\end{array}$ & $\begin{array}{r}99.58 \\
(0.482) \\
\end{array}$ & $\begin{array}{l}100.91 \\
(0.533) \\
\end{array}$ & $\begin{array}{l}120.64 \\
(0.954) \\
\end{array}$ & $\begin{array}{r}149.84 \\
(0.983) \\
\end{array}$ & $\begin{array}{r}73.92 \\
(0.000) \\
\end{array}$ & $\begin{array}{r}81.50 \\
(0.008) \\
\end{array}$ \\
\hline $\begin{array}{l}\text { Model 3Y } \\
\mathrm{p}(\mathrm{CW})\end{array}$ & $\begin{array}{r}99.93 \\
(0.237) \\
\end{array}$ & $\begin{array}{r}99.71 \\
(0.185) \\
\end{array}$ & $\begin{array}{r}99.44 \\
(0.144) \\
\end{array}$ & $\begin{array}{r}98.97 \\
(0.089) \\
\end{array}$ & $\begin{array}{r}98.28 \\
(0.050) \\
\end{array}$ & $\begin{array}{r}96.64 \\
(0.018) \\
\end{array}$ & $\begin{array}{r}97.45 \\
(0.034) \\
\end{array}$ & $\begin{array}{l}100.34 \\
(0.138) \\
\end{array}$ & $\begin{array}{r}103.18 \\
(0.761) \\
\end{array}$ & $\begin{array}{r}69.09 \\
(0.001) \\
\end{array}$ & $\begin{array}{r}96.07 \\
(0.009) \\
\end{array}$ & $\begin{array}{r}99.33 \\
(0.097) \\
\end{array}$ \\
\hline $\begin{array}{l}\text { Model 5Y } \\
\mathrm{p}(\mathrm{CW})\end{array}$ & $\begin{array}{r}99.80 \\
(0.143) \\
\end{array}$ & $\begin{array}{r}99.20 \\
(0.082) \\
\end{array}$ & $\begin{array}{r}98.32 \\
(0.045) \\
\end{array}$ & $\begin{array}{r}96.78 \\
(0.013) \\
\end{array}$ & $\begin{array}{r}94.00 \\
(0.001) \\
\end{array}$ & $\begin{array}{r}91.26 \\
(0.000) \\
\end{array}$ & $\begin{array}{r}90.47 \\
(0.000) \\
\end{array}$ & $\begin{array}{r}91.81 \\
(0.001) \\
\end{array}$ & $\begin{array}{r}93.33 \\
(0.005) \\
\end{array}$ & $\begin{array}{r}73.63 \\
(0.006) \\
\end{array}$ & $\begin{array}{r}87.25 \\
(0.000) \\
\end{array}$ & $\begin{array}{r}103.08 \\
(0.166) \\
\end{array}$ \\
\hline $\begin{array}{l}\text { Model 10Y } \\
\mathrm{p}(\mathrm{CW})\end{array}$ & $\begin{array}{l}100.04 \\
(0.123) \\
\end{array}$ & $\begin{array}{r}99.14 \\
(0.052) \\
\end{array}$ & $\begin{array}{r}97.72 \\
(0.026) \\
\end{array}$ & $\begin{array}{r}95.44 \\
(0.005) \\
\end{array}$ & $\begin{array}{r}94.12 \\
(0.004) \\
\end{array}$ & $\begin{array}{r}97.16 \\
(0.022) \\
\end{array}$ & $\begin{array}{l}100.61 \\
(0.042)\end{array}$ & $\begin{array}{l}108.15 \\
(0.089) \\
\end{array}$ & $\begin{array}{r}100.62 \\
(0.277) \\
\end{array}$ & $\begin{array}{r}142.57 \\
(0.147) \\
\end{array}$ & $\begin{array}{r}67.63 \\
(0.000) \\
\end{array}$ & $\begin{array}{r}104.11 \\
(0.607)\end{array}$ \\
\hline \multirow[t]{2}{*}{$\begin{array}{l}\text { Combined } \\
\mathrm{p}(\mathrm{CW})\end{array}$} & $\begin{array}{r}99.81 \\
(0.131) \\
\end{array}$ & $\begin{array}{r}99.04 \\
(0.063) \\
\end{array}$ & $\begin{array}{r}97.96 \\
(0.032) \\
\end{array}$ & $\begin{array}{r}96.27 \\
(0.008) \\
\end{array}$ & $\begin{array}{r}94.19 \\
(0.002) \\
\end{array}$ & $\begin{array}{r}93.10 \\
(0.004) \\
\end{array}$ & $\begin{array}{r}93.64 \\
(0.008) \\
\end{array}$ & $\begin{array}{r}96.50 \\
(0.033) \\
\end{array}$ & $\begin{array}{r}97.88 \\
(0.237) \\
\end{array}$ & $\begin{array}{r}87.71 \\
(0.030) \\
\end{array}$ & $\begin{array}{r}82.80 \\
(0.000) \\
\end{array}$ & $\begin{array}{r}100.33 \\
(0.164) \\
\end{array}$ \\
\hline & \multicolumn{12}{|c|}{ Correct sign prediction compared to the spot rate, $\%$} \\
\hline $\begin{array}{l}\text { Forward } \\
\mathrm{p}\end{array}$ & $\begin{array}{r}52.2 \\
(0.152) \\
\end{array}$ & $\begin{array}{r}48.3 \\
(0.593) \\
\end{array}$ & $\begin{array}{r}51.8 \\
(0.166) \\
\end{array}$ & $\begin{array}{r}57.5 \\
(0.001) \\
\end{array}$ & $\begin{array}{r}55.2 \\
(0.142) \\
\end{array}$ & $\begin{array}{r}59.3 \\
(0.010) \\
\end{array}$ & $\begin{array}{r}65.1 \\
(0.000) \\
\end{array}$ & $\begin{array}{r}67.0 \\
(0.000) \\
\end{array}$ & $\begin{array}{r}51.2 \\
(0.947) \\
\end{array}$ & $\begin{array}{r}47.6 \\
\text { n.a. }\end{array}$ & $\begin{array}{c}97.9 \\
\text { n.a. }\end{array}$ & $\begin{array}{r}57.3 \\
(0.000) \\
\end{array}$ \\
\hline $\begin{array}{l}\text { Model 3Y } \\
\text { p }\end{array}$ & $\begin{array}{r}50.8 \\
(0.344) \\
\end{array}$ & $\begin{array}{r}53.3 \\
(0.129) \\
\end{array}$ & $\begin{array}{r}54.1 \\
(0.053) \\
\end{array}$ & $\begin{array}{r}51.0 \\
(0.255) \\
\end{array}$ & $\begin{array}{r}61.1 \\
(0.000) \\
\end{array}$ & $\begin{array}{r}60.9 \\
(0.000) \\
\end{array}$ & $\begin{array}{r}56.2 \\
(0.040) \\
\end{array}$ & $\begin{array}{r}55.8 \\
(0.163) \\
\end{array}$ & $\begin{array}{r}59.5 \\
(0.062) \\
\end{array}$ & $\begin{array}{r}61.9 \\
(0.000) \\
\end{array}$ & $\begin{array}{r}70.8 \\
(0.065) \\
\end{array}$ & $\begin{array}{r}56.4 \\
(0.183) \\
\end{array}$ \\
\hline $\begin{array}{l}\text { Model 5Y } \\
\mathrm{p}\end{array}$ & $\begin{array}{r}53.0 \\
(0.097) \\
\end{array}$ & $\begin{array}{r}56.4 \\
(0.009) \\
\end{array}$ & $\begin{array}{r}57.4 \\
(0.002) \\
\end{array}$ & $\begin{array}{r}55.8 \\
(0.007) \\
\end{array}$ & $\begin{array}{r}61.9 \\
(0.000) \\
\end{array}$ & $\begin{array}{r}64.2 \\
(0.000) \\
\end{array}$ & $\begin{array}{r}61.0 \\
(0.001) \\
\end{array}$ & $\begin{array}{r}60.1 \\
(0.038) \\
\end{array}$ & $\begin{array}{r}70.2 \\
(0.000) \\
\end{array}$ & $\begin{array}{r}51.2 \\
(0.045) \\
\end{array}$ & $\begin{array}{r}95.8 \\
(0.559) \\
\end{array}$ & $\begin{array}{r}56.4 \\
(0.183) \\
\end{array}$ \\
\hline $\begin{array}{l}\text { Model 10Y } \\
\mathrm{p}\end{array}$ & $\begin{array}{r}53.3 \\
(0.097) \\
\end{array}$ & $\begin{array}{r}54.2 \\
(0.062) \\
\end{array}$ & $\begin{array}{r}56.3 \\
(0.008) \\
\end{array}$ & $\begin{array}{r}62.4 \\
(0.000) \\
\end{array}$ & $\begin{array}{r}58.4 \\
(0.003) \\
\end{array}$ & $\begin{array}{r}57.8 \\
(0.057) \\
\end{array}$ & $\begin{array}{r}55.2 \\
(0.767) \\
\end{array}$ & $\begin{array}{r}60.1 \\
(0.960) \\
\end{array}$ & $\begin{array}{r}54.8 \\
\text { n.a. }\end{array}$ & $\begin{array}{r}47.6 \\
\text { n.a. }\end{array}$ & $\begin{array}{r}97.9 \\
\text { n.a. }\end{array}$ & $\begin{array}{r}50.0 \\
(0.654) \\
\end{array}$ \\
\hline $\begin{array}{l}\text { Combined } \\
\mathrm{p}\end{array}$ & $\begin{array}{r}53.3 \\
(0.093) \\
\end{array}$ & $\begin{array}{r}53.9 \\
(0.082) \\
\end{array}$ & $\begin{array}{r}56.0 \\
(0.011) \\
\end{array}$ & $\begin{array}{r}55.3 \\
(0.025) \\
\end{array}$ & $\begin{array}{r}58.7 \\
(0.002) \\
\end{array}$ & $\begin{array}{r}59.6 \\
(0.003) \\
\end{array}$ & $\begin{array}{r}59.0 \\
(0.018) \\
\end{array}$ & $\begin{array}{r}60.7 \\
(0.058) \\
\end{array}$ & $\begin{array}{r}52.4 \\
(0.905) \\
\end{array}$ & $\begin{array}{r}47.6 \\
\text { n.a. } \\
\end{array}$ & $\begin{array}{r}97.9 \\
\text { n.a. }\end{array}$ & $\begin{array}{r}57.3 \\
(0.098) \\
\end{array}$ \\
\hline & \multicolumn{12}{|c|}{ Correct sign prediction compared to the forward rate, \% } \\
\hline $\begin{array}{l}\text { Model 3Y } \\
\mathrm{p}\end{array}$ & $\begin{array}{r}53.9 \\
(0.151) \\
\end{array}$ & $\begin{array}{r}56.4 \\
(0.050) \\
\end{array}$ & $\begin{array}{r}56.9 \\
(0.079) \\
\end{array}$ & $\begin{array}{r}62.4 \\
(0.000) \\
\end{array}$ & $\begin{array}{r}65.8 \\
(0.000) \\
\end{array}$ & $\begin{array}{r}62.7 \\
(0.000) \\
\end{array}$ & $\begin{array}{r}57.1 \\
(0.000) \\
\end{array}$ & $\begin{array}{r}53.5 \\
(0.000) \\
\end{array}$ & $\begin{array}{r}61.9 \\
(0.000) \\
\end{array}$ & $\begin{array}{r}96.4 \\
(0.000) \\
\end{array}$ & $\begin{array}{r}25.0 \\
\text { n.a. }\end{array}$ & $\begin{array}{r}54.5 \\
\text { n.a. }\end{array}$ \\
\hline $\begin{array}{l}\text { Model 5Y } \\
\mathrm{p}\end{array}$ & $\begin{array}{r}54.7 \\
(0.069) \\
\end{array}$ & $\begin{array}{r}57.2 \\
(0.018) \\
\end{array}$ & $\begin{array}{r}56.9 \\
(0.075) \\
\end{array}$ & $\begin{array}{r}64.4 \\
(0.000) \\
\end{array}$ & $\begin{array}{r}66.1 \\
(0.000) \\
\end{array}$ & $\begin{array}{r}64.5 \\
(0.000) \\
\end{array}$ & $\begin{array}{r}57.8 \\
(0.000) \\
\end{array}$ & $\begin{array}{r}52.8 \\
(0.002) \\
\end{array}$ & $\begin{array}{r}67.9 \\
(0.000) \\
\end{array}$ & $\begin{array}{r}96.4 \\
(0.000) \\
\end{array}$ & $\begin{array}{r}27.1 \\
(0.278) \\
\end{array}$ & $\begin{array}{r}54.5 \\
\text { n.a. }\end{array}$ \\
\hline $\begin{array}{l}\text { Model 10Y } \\
\mathrm{p}\end{array}$ & $\begin{array}{r}54.7 \\
(0.070) \\
\end{array}$ & $\begin{array}{r}52.8 \\
(0.359) \\
\end{array}$ & $\begin{array}{r}53.8 \\
(0.211) \\
\end{array}$ & $\begin{array}{r}63.0 \\
(0.000) \\
\end{array}$ & $\begin{array}{r}67.6 \\
(0.000) \\
\end{array}$ & $\begin{array}{r}59.3 \\
(0.000) \\
\end{array}$ & $\begin{array}{r}52.1 \\
(0.346) \\
\end{array}$ & $\begin{array}{r}55.4 \\
(0.254) \\
\end{array}$ & $\begin{array}{r}73.8 \\
(0.000) \\
\end{array}$ & $\begin{array}{r}53.6 \\
(0.004) \\
\end{array}$ & $\begin{array}{r}70.8 \\
(0.007) \\
\end{array}$ & $\begin{array}{r}48.2 \\
(0.986) \\
\end{array}$ \\
\hline $\begin{array}{l}\text { Combined } \\
p\end{array}$ & $\begin{array}{r}54.4 \\
(0.094) \\
\end{array}$ & $\begin{array}{r}57.2 \\
(0.018) \\
\end{array}$ & $\begin{array}{r}56.0 \\
(0.128) \\
\end{array}$ & $\begin{array}{r}63.2 \\
(0.000) \\
\end{array}$ & $\begin{array}{r}66.7 \\
(0.000) \\
\end{array}$ & $\begin{array}{r}63.3 \\
(0.000) \\
\end{array}$ & $\begin{array}{r}55.2 \\
(0.003) \\
\end{array}$ & $\begin{array}{r}51.5 \\
(0.033) \\
\end{array}$ & $\begin{array}{r}69.0 \\
(0.000) \\
\end{array}$ & $\begin{array}{r}90.5 \\
(0.000) \\
\end{array}$ & $\begin{array}{r}27.1 \\
(0.278) \\
\end{array}$ & $\begin{array}{r}54.5 \\
\text { n.a. }\end{array}$ \\
\hline & \multicolumn{12}{|c|}{ Mean annualized profit, \% per year } \\
\hline $\begin{array}{l}\text { Carry trade } \\
\mathrm{p}(=0)\end{array}$ & $\begin{array}{r}1.0 \\
(0.241) \\
\end{array}$ & $\begin{array}{r}0.6 \\
(0.321) \\
\end{array}$ & $\begin{array}{r}0.7 \\
(0.270) \\
\end{array}$ & $\begin{array}{r}0.1 \\
(0.480) \\
\end{array}$ & $\begin{array}{r}0.3 \\
(0.372) \\
\end{array}$ & $\begin{array}{r}0.1 \\
(0.439) \\
\end{array}$ & $\begin{array}{r}-0.1 \\
(0.593) \\
\end{array}$ & $\begin{array}{r}0.3 \\
(0.243) \\
\end{array}$ & $\begin{array}{r}2.0 \\
(0.082) \\
\end{array}$ & $\begin{array}{r}1.1 \\
(0.082) \\
\end{array}$ & $\begin{array}{r}-4.0 \\
(1.000) \\
\end{array}$ & $\begin{array}{r}-0.2 \\
(0.650) \\
\end{array}$ \\
\hline $\begin{array}{l}\text { Model 3Y } \\
\mathrm{p}(=0) \\
\mathrm{p}(=\mathrm{CT})\end{array}$ & $\begin{array}{r}1.3 \\
(0.199) \\
(0.410) \\
\end{array}$ & $\begin{array}{r}1.3 \\
(0.173) \\
(0.146) \\
\end{array}$ & $\begin{array}{r}1.6 \\
(0.089) \\
(0.057) \\
\end{array}$ & $\begin{array}{r}1.3 \\
(0.110) \\
(0.009) \\
\end{array}$ & $\begin{array}{r}1.3 \\
(0.049) \\
(0.000) \\
\end{array}$ & $\begin{array}{r}1.0 \\
(0.044) \\
(0.000) \\
\end{array}$ & $\begin{array}{r}0.7 \\
(0.109) \\
(0.001) \\
\end{array}$ & $\begin{array}{r}0.6 \\
(0.089) \\
(0.090) \\
\end{array}$ & $\begin{array}{r}3.0 \\
(0.009) \\
(0.004) \\
\end{array}$ & $\begin{array}{r}3.4 \\
(0.000) \\
(0.000) \\
\end{array}$ & $\begin{array}{r}-4.0 \\
(1.000) \\
\text { n.a. }\end{array}$ & $\begin{array}{r}0.1 \\
(0.424) \\
(0.046) \\
\end{array}$ \\
\hline $\begin{array}{l}\text { Model 5Y } \\
\mathrm{p}(=0) \\
\mathrm{p}(=\mathrm{CT})\end{array}$ & $\begin{array}{r}1.5 \\
(0.151) \\
(0.339) \\
\end{array}$ & $\begin{array}{r}1.6 \\
(0.113) \\
(0.088) \\
\end{array}$ & $\begin{array}{r}2.0 \\
(0.044) \\
(0.029) \\
\end{array}$ & $\begin{array}{r}1.6 \\
(0.048) \\
(0.003) \\
\end{array}$ & $\begin{array}{r}1.4 \\
(0.029) \\
(0.000) \\
\end{array}$ & $\begin{array}{r}1.3 \\
(0.016) \\
(0.000) \\
\end{array}$ & $\begin{array}{r}0.7 \\
(0.075) \\
(0.003) \\
\end{array}$ & $\begin{array}{r}0.6 \\
(0.109) \\
(0.199) \\
\end{array}$ & $\begin{array}{r}3.8 \\
(0.001) \\
(0.001) \\
\end{array}$ & $\begin{array}{r}3.4 \\
(0.000) \\
(0.000) \\
\end{array}$ & $\begin{array}{r}-3.8 \\
(1.000) \\
(0.021) \\
\end{array}$ & $\begin{array}{r}0.1 \\
(0.424) \\
(0.046) \\
\end{array}$ \\
\hline $\begin{array}{l}\text { Model 10Y } \\
\mathrm{p}(=0) \\
\mathrm{p}(=\mathrm{CT})\end{array}$ & $\begin{array}{r}0.6 \\
(0.333) \\
(0.605) \\
\end{array}$ & $\begin{array}{r}0.7 \\
(0.295) \\
(0.486) \\
\end{array}$ & $\begin{array}{r}1.4 \\
(0.108) \\
(0.269) \\
\end{array}$ & $\begin{array}{r}2.2 \\
(0.013) \\
(0.034) \\
\end{array}$ & $\begin{array}{r}2.4 \\
(0.000) \\
(0.010) \\
\end{array}$ & $\begin{array}{r}1.5 \\
(0.005) \\
(0.045) \\
\end{array}$ & $\begin{array}{r}0.8 \\
(0.062) \\
(0.089) \\
\end{array}$ & $\begin{array}{r}0.2 \\
(0.285) \\
(0.550) \\
\end{array}$ & $\begin{array}{r}3.9 \\
(0.000) \\
(0.053) \\
\end{array}$ & $\begin{array}{r}0.2 \\
(0.388) \\
(0.750) \\
\end{array}$ & $\begin{array}{r}3.4 \\
(0.003) \\
(0.000) \\
\end{array}$ & $\begin{array}{r}-0.3 \\
(0.681) \\
(0.514) \\
\end{array}$ \\
\hline $\begin{array}{l}\text { Combined } \\
\mathrm{p}(=0) \\
\mathrm{p}(=\mathrm{CT})\end{array}$ & $\begin{array}{r}1.2 \\
(0.191) \\
(0.440) \\
\end{array}$ & $\begin{array}{r}2.0 \\
(0.063) \\
(0.115) \\
\end{array}$ & $\begin{array}{r}1.7 \\
(0.069) \\
(0.092) \\
\end{array}$ & $\begin{array}{r}1.5 \\
(0.059) \\
(0.012) \\
\end{array}$ & $\begin{array}{r}1.6 \\
(0.015) \\
(0.000) \\
\end{array}$ & $\begin{array}{r}1.3 \\
(0.016) \\
(0.000) \\
\end{array}$ & $\begin{array}{r}0.6 \\
(0.115) \\
(0.033) \\
\end{array}$ & $\begin{array}{r}0.5 \\
(0.129) \\
(0.285) \\
\end{array}$ & $\begin{array}{r}4.0 \\
(0.000) \\
(0.001) \\
\end{array}$ & $\begin{array}{r}3.1 \\
(0.000) \\
(0.000) \\
\end{array}$ & $\begin{array}{r}-3.8 \\
(1.000) \\
(0.021) \\
\end{array}$ & $\begin{array}{r}0.1 \\
(0.424) \\
(0.046) \\
\end{array}$ \\
\hline
\end{tabular}


Table A3 continued: Out-of-sample forecast evaluation, baseline results

JPY/DEM

Full sample, different forecast horizons

Different samples, 36M forecast

\begin{tabular}{|c|c|c|c|c|c|c|c|c|c|c|c|c|}
\hline \multirow[t]{3}{*}{ 年 } & \multicolumn{8}{|c|}{ 20. } & \multicolumn{4}{|c|}{ horizon } \\
\hline & $1 \mathrm{M}$ & $3 \mathrm{M}$ & $6 \mathrm{M}$ & $12 \mathrm{M}$ & $24 \mathrm{M}$ & $36 \mathrm{M}$ & $48 \mathrm{M}$ & $60 \mathrm{M}$ & $\begin{array}{c}1993- \\
99 \\
\end{array}$ & $\begin{array}{c}2000- \\
06\end{array}$ & $\begin{array}{c}2007- \\
10 \\
\end{array}$ & $\begin{array}{c}2011- \\
20\end{array}$ \\
\hline & \multicolumn{12}{|c|}{ Mean squared forecast error (MSFE), random walk without drift $=100$} \\
\hline $\begin{array}{l}\text { Forward } \\
\mathrm{p}\end{array}$ & $\begin{array}{r}99.84 \\
(0.422) \\
\end{array}$ & $\begin{array}{r}99.49 \\
(0.405) \\
\end{array}$ & $\begin{array}{r}99.29 \\
(0.425) \\
\end{array}$ & $\begin{array}{r}99.24 \\
(0.444) \\
\end{array}$ & $\begin{array}{r}99.86 \\
(0.493) \\
\end{array}$ & $\begin{array}{l}103.69 \\
(0.635) \\
\end{array}$ & $\begin{array}{l}110.54 \\
(0.766)\end{array}$ & $\begin{array}{r}122.92 \\
(0.878) \\
\end{array}$ & $\begin{array}{r}91.20 \\
(0.288) \\
\end{array}$ & $\begin{array}{l}134.92 \\
(0.954) \\
\end{array}$ & $\begin{array}{r}91.74 \\
(0.340) \\
\end{array}$ & $\begin{array}{r}88.50 \\
(0.115) \\
\end{array}$ \\
\hline $\begin{array}{l}\text { Model 3Y } \\
\mathrm{p}(\mathrm{CW})\end{array}$ & $\begin{array}{r}99.87 \\
(0.270) \\
\end{array}$ & $\begin{array}{r}99.78 \\
(0.315) \\
\end{array}$ & $\begin{array}{r}99.13 \\
(0.229) \\
\end{array}$ & $\begin{array}{r}98.07 \\
(0.154) \\
\end{array}$ & $\begin{array}{r}96.06 \\
(0.064) \\
\end{array}$ & $\begin{array}{r}92.59 \\
(0.008) \\
\end{array}$ & $\begin{array}{r}89.56 \\
(0.001) \\
\end{array}$ & $\begin{array}{r}88.28 \\
(0.003) \\
\end{array}$ & $\begin{array}{l}109.60 \\
(0.804) \\
\end{array}$ & $\begin{array}{r}99.36 \\
(0.279) \\
\end{array}$ & $\begin{array}{r}83.16 \\
(0.004) \\
\end{array}$ & $\begin{array}{r}75.34 \\
(0.000) \\
\end{array}$ \\
\hline $\begin{array}{l}\text { Model 5Y } \\
\mathrm{p}(\mathrm{CW})\end{array}$ & $\begin{array}{r}99.95 \\
(0.335) \\
\end{array}$ & $\begin{array}{r}100.08 \\
(0.405) \\
\end{array}$ & $\begin{array}{r}99.78 \\
(0.323) \\
\end{array}$ & $\begin{array}{r}99.21 \\
(0.244) \\
\end{array}$ & $\begin{array}{r}98.06 \\
(0.138) \\
\end{array}$ & $\begin{array}{r}95.45 \\
(0.037) \\
\end{array}$ & $\begin{array}{r}92.94 \\
(0.011) \\
\end{array}$ & $\begin{array}{r}92.23 \\
(0.017) \\
\end{array}$ & $\begin{array}{l}112.43 \\
(0.890) \\
\end{array}$ & $\begin{array}{r}102.15 \\
(0.418) \\
\end{array}$ & $\begin{array}{r}84.24 \\
(0.002) \\
\end{array}$ & $\begin{array}{r}79.36 \\
(0.000) \\
\end{array}$ \\
\hline $\begin{array}{l}\text { Model 10Y } \\
\mathrm{p}(\mathrm{CW})\end{array}$ & $\begin{array}{r}100.15 \\
(0.494) \\
\end{array}$ & $\begin{array}{l}100.65 \\
(0.582) \\
\end{array}$ & $\begin{array}{r}100.90 \\
(0.518) \\
\end{array}$ & $\begin{array}{l}101.27 \\
(0.466) \\
\end{array}$ & $\begin{array}{l}102.18 \\
(0.447) \\
\end{array}$ & $\begin{array}{l}102.15 \\
(0.364) \\
\end{array}$ & $\begin{array}{l}101.53 \\
(0.253) \\
\end{array}$ & $\begin{array}{l}102.62 \\
(0.255) \\
\end{array}$ & $\begin{array}{l}115.75 \\
(0.924) \\
\end{array}$ & $\begin{array}{r}110.41 \\
(0.758) \\
\end{array}$ & $\begin{array}{r}86.91 \\
(0.002) \\
\end{array}$ & $\begin{array}{r}89.75 \\
(0.000) \\
\end{array}$ \\
\hline $\begin{array}{l}\text { Combined } \\
\mathrm{p}(\mathrm{CW})\end{array}$ & $\begin{array}{r}99.98 \\
(0.358) \\
\end{array}$ & $\begin{array}{l}100.14 \\
(0.426) \\
\end{array}$ & $\begin{array}{r}99.88 \\
(0.339) \\
\end{array}$ & $\begin{array}{r}99.42 \\
(0.261) \\
\end{array}$ & $\begin{array}{r}98.59 \\
(0.167) \\
\end{array}$ & $\begin{array}{r}96.48 \\
(0.061) \\
\end{array}$ & $\begin{array}{r}94.35 \\
(0.024) \\
\end{array}$ & $\begin{array}{r}93.91 \\
(0.032) \\
\end{array}$ & $\begin{array}{r}112.33 \\
(0.890) \\
\end{array}$ & $\begin{array}{r}103.85 \\
(0.515) \\
\end{array}$ & $\begin{array}{r}84.73 \\
(0.003) \\
\end{array}$ & $\begin{array}{r}80.99 \\
(0.000) \\
\end{array}$ \\
\hline & \multicolumn{12}{|c|}{ Correct sign prediction compared to the spot rate, $\%$} \\
\hline $\begin{array}{l}\text { Forward } \\
\mathrm{p}\end{array}$ & $\begin{array}{r}50.8 \\
(0.084) \\
\end{array}$ & $\begin{array}{r}47.2 \\
(0.757) \\
\end{array}$ & $\begin{array}{r}48.2 \\
(0.824) \\
\end{array}$ & $\begin{array}{r}47.9 \\
(0.821) \\
\end{array}$ & $\begin{array}{r}51.0 \\
(0.394) \\
\end{array}$ & $\begin{array}{r}50.8 \\
(0.909) \\
\end{array}$ & $\begin{array}{r}49.5 \\
(1.000) \\
\end{array}$ & $\begin{array}{r}54.5 \\
(0.964) \\
\end{array}$ & $\begin{array}{r}63.1 \\
\text { n.a. }\end{array}$ & $\begin{array}{r}36.9 \\
\text { n.a. }\end{array}$ & $\begin{array}{r}56.3 \\
\text { n.a. }\end{array}$ & $\begin{array}{r}49.1 \\
(0.761) \\
\end{array}$ \\
\hline $\begin{array}{l}\text { Model 3Y } \\
\mathrm{p}\end{array}$ & $\begin{array}{r}51.7 \\
(0.426) \\
\end{array}$ & $\begin{array}{r}52.2 \\
(0.265) \\
\end{array}$ & $\begin{array}{r}55.7 \\
(0.010) \\
\end{array}$ & $\begin{array}{r}59.5 \\
(0.000) \\
\end{array}$ & $\begin{array}{r}64.6 \\
(0.000) \\
\end{array}$ & $\begin{array}{r}68.5 \\
(0.000) \\
\end{array}$ & $\begin{array}{r}71.1 \\
(0.000) \\
\end{array}$ & $\begin{array}{r}65.0 \\
(0.000) \\
\end{array}$ & $\begin{array}{r}52.4 \\
(0.001) \\
\end{array}$ & $\begin{array}{r}60.7 \\
(0.694) \\
\end{array}$ & $\begin{array}{r}85.4 \\
(0.000) \\
\end{array}$ & $\begin{array}{r}80.0 \\
(0.000) \\
\end{array}$ \\
\hline $\begin{array}{l}\text { Model 5Y } \\
\mathrm{p}\end{array}$ & $\begin{array}{r}51.4 \\
(0.417) \\
\end{array}$ & $\begin{array}{r}52.8 \\
(0.184) \\
\end{array}$ & $\begin{array}{r}54.6 \\
(0.033) \\
\end{array}$ & $\begin{array}{r}55.8 \\
(0.012) \\
\end{array}$ & $\begin{array}{r}58.1 \\
(0.001) \\
\end{array}$ & $\begin{array}{r}66.1 \\
(0.000) \\
\end{array}$ & $\begin{array}{r}70.2 \\
(0.000) \\
\end{array}$ & $\begin{array}{r}62.7 \\
(0.000) \\
\end{array}$ & $\begin{array}{r}44.0 \\
(0.065) \\
\end{array}$ & $\begin{array}{r}59.5 \\
(0.913) \\
\end{array}$ & $\begin{array}{r}83.3 \\
(0.000) \\
\end{array}$ & $\begin{array}{r}80.9 \\
(0.000) \\
\end{array}$ \\
\hline $\begin{array}{l}\text { Model 10Y } \\
\mathrm{p}\end{array}$ & $\begin{array}{r}49.2 \\
(0.737) \\
\end{array}$ & $\begin{array}{r}48.9 \\
(0.727) \\
\end{array}$ & $\begin{array}{r}50.7 \\
(0.380) \\
\end{array}$ & $\begin{array}{r}51.9 \\
(0.241) \\
\end{array}$ & $\begin{array}{r}53.4 \\
(0.085) \\
\end{array}$ & $\begin{array}{r}62.4 \\
(0.000) \\
\end{array}$ & $\begin{array}{r}69.5 \\
(0.000) \\
\end{array}$ & $\begin{array}{r}62.0 \\
(0.000) \\
\end{array}$ & $\begin{array}{r}41.7 \\
(0.142) \\
\end{array}$ & $\begin{array}{r}59.5 \\
(0.913) \\
\end{array}$ & $\begin{array}{r}77.1 \\
(0.000) \\
\end{array}$ & $\begin{array}{r}74.5 \\
(0.000) \\
\end{array}$ \\
\hline $\begin{array}{l}\text { Combined } \\
\mathrm{p}\end{array}$ & $\begin{array}{r}49.7 \\
(0.676) \\
\end{array}$ & $\begin{array}{r}51.1 \\
(0.405) \\
\end{array}$ & $\begin{array}{r}53.2 \\
(0.098) \\
\end{array}$ & $\begin{array}{r}53.8 \\
(0.070) \\
\end{array}$ & $\begin{array}{r}55.2 \\
(0.019) \\
\end{array}$ & $\begin{array}{r}64.5 \\
(0.000) \\
\end{array}$ & $\begin{array}{r}70.2 \\
(0.000) \\
\end{array}$ & $\begin{array}{r}65.0 \\
(0.000) \\
\end{array}$ & $\begin{array}{r}44.0 \\
(0.065) \\
\end{array}$ & $\begin{array}{r}60.7 \\
(0.865) \\
\end{array}$ & $\begin{array}{r}77.1 \\
(0.000) \\
\end{array}$ & $\begin{array}{r}78.2 \\
(0.000) \\
\end{array}$ \\
\hline & \multicolumn{12}{|c|}{ Correct sign prediction compared to the forward rate, \% } \\
\hline $\begin{array}{l}\text { Model 3Y } \\
\mathrm{p}\end{array}$ & $\begin{array}{r}57.7 \\
(0.052) \\
\end{array}$ & $\begin{array}{r}60.3 \\
(0.000) \\
\end{array}$ & $\begin{array}{r}61.1 \\
(0.000) \\
\end{array}$ & $\begin{array}{r}65.0 \\
(0.000) \\
\end{array}$ & $\begin{array}{r}59.0 \\
(0.000) \\
\end{array}$ & $\begin{array}{r}61.8 \\
(0.000) \\
\end{array}$ & $\begin{array}{r}64.4 \\
(0.000) \\
\end{array}$ & $\begin{array}{r}68.3 \\
(0.000) \\
\end{array}$ & $\begin{array}{r}51.2 \\
(0.080) \\
\end{array}$ & $\begin{array}{r}65.5 \\
\text { n.a. } \\
\end{array}$ & $\begin{array}{r}45.8 \\
\text { n.a. }\end{array}$ & $\begin{array}{r}74.5 \\
(0.000) \\
\end{array}$ \\
\hline $\begin{array}{l}\text { Model 5Y } \\
\mathrm{p}\end{array}$ & $\begin{array}{r}55.8 \\
(0.175) \\
\end{array}$ & $\begin{array}{r}59.2 \\
(0.002) \\
\end{array}$ & $\begin{array}{r}59.1 \\
(0.001) \\
\end{array}$ & $\begin{array}{r}63.0 \\
(0.000) \\
\end{array}$ & $\begin{array}{r}56.3 \\
(0.018) \\
\end{array}$ & $\begin{array}{r}59.6 \\
(0.000) \\
\end{array}$ & $\begin{array}{r}63.8 \\
(0.000) \\
\end{array}$ & $\begin{array}{r}67.3 \\
(0.000) \\
\end{array}$ & $\begin{array}{r}51.2 \\
(0.080) \\
\end{array}$ & $\begin{array}{r}65.5 \\
\text { n.a. } \\
\end{array}$ & $\begin{array}{r}45.8 \\
\text { n.a. }\end{array}$ & $\begin{array}{r}68.2 \\
(0.000) \\
\end{array}$ \\
\hline $\begin{array}{l}\text { Model 10Y } \\
\mathrm{p}\end{array}$ & $\begin{array}{r}54.1 \\
(0.400) \\
\end{array}$ & $\begin{array}{r}56.9 \\
(0.030) \\
\end{array}$ & $\begin{array}{r}58.0 \\
(0.005) \\
\end{array}$ & $\begin{array}{r}61.5 \\
(0.000) \\
\end{array}$ & $\begin{array}{r}55.2 \\
(0.063) \\
\end{array}$ & $\begin{array}{r}58.1 \\
(0.000) \\
\end{array}$ & $\begin{array}{r}64.4 \\
(0.000) \\
\end{array}$ & $\begin{array}{r}66.0 \\
(0.000) \\
\end{array}$ & $\begin{array}{r}50.0 \\
(0.162) \\
\end{array}$ & $\begin{array}{r}65.5 \\
\text { n.a. } \\
\end{array}$ & $\begin{array}{r}45.8 \\
\text { n.a. }\end{array}$ & $\begin{array}{r}64.5 \\
(0.001) \\
\end{array}$ \\
\hline $\begin{array}{l}\text { Combined } \\
\mathrm{p}\end{array}$ & $\begin{array}{r}55.2 \\
(0.237) \\
\end{array}$ & $\begin{array}{r}58.1 \\
(0.009) \\
\end{array}$ & $\begin{array}{r}58.8 \\
(0.001) \\
\end{array}$ & $\begin{array}{r}62.4 \\
(0.000) \\
\end{array}$ & $\begin{array}{r}56.0 \\
(0.026) \\
\end{array}$ & $\begin{array}{r}59.0 \\
(0.000) \\
\end{array}$ & $\begin{array}{r}64.1 \\
(0.000) \\
\end{array}$ & $\begin{array}{r}67.3 \\
(0.000) \\
\end{array}$ & $\begin{array}{r}50.0 \\
(0.162) \\
\end{array}$ & $\begin{array}{r}65.5 \\
\text { n.a. } \\
\end{array}$ & $\begin{array}{r}45.8 \\
\text { n.a. } \\
\end{array}$ & $\begin{array}{r}67.3 \\
(0.000) \\
\end{array}$ \\
\hline & \multicolumn{12}{|c|}{ Mean annualized profit, \% per year } \\
\hline $\begin{array}{l}\text { Carry trade } \\
\mathrm{p}(=0)\end{array}$ & $\begin{array}{r}-0.6 \\
(0.597) \\
\end{array}$ & $\begin{array}{r}0.0 \\
(0.504) \\
\end{array}$ & $\begin{array}{r}0.0 \\
(0.502) \\
\end{array}$ & $\begin{array}{r}-0.3 \\
(0.580) \\
\end{array}$ & $\begin{array}{r}0.9 \\
(0.213) \\
\end{array}$ & $\begin{array}{r}1.2 \\
(0.094) \\
\end{array}$ & $\begin{array}{r}1.8 \\
(0.009) \\
\end{array}$ & $\begin{array}{r}1.9 \\
(0.001) \\
\end{array}$ & $\begin{array}{r}-0.1 \\
(0.534) \\
\end{array}$ & $\begin{array}{r}4.1 \\
(0.009) \\
\end{array}$ & $\begin{array}{r}1.1 \\
(0.282) \\
\end{array}$ & $\begin{array}{r}0.1 \\
(0.458) \\
\end{array}$ \\
\hline $\begin{array}{l}\text { Model 3Y } \\
\text { p (=0) }\end{array}$ & $\begin{array}{r}3.3 \\
(0.078)\end{array}$ & $\begin{array}{r}2.4 \\
(0.119)\end{array}$ & $\begin{array}{r}1.9 \\
(0.147)\end{array}$ & $\begin{array}{r}2.3 \\
(0.057)\end{array}$ & $\begin{array}{r}2.0 \\
(0.034)\end{array}$ & $\begin{array}{r}2.0 \\
(0.015)\end{array}$ & $\begin{array}{r}1.9 \\
(0.005)\end{array}$ & $\begin{array}{r}2.0 \\
(0.000)\end{array}$ & $\begin{array}{r}0.4 \\
(0.385)\end{array}$ & $\begin{array}{r}4.1 \\
(0.009)\end{array}$ & $\begin{array}{r}1.1 \\
(0.282)\end{array}$ & $\begin{array}{r}1.9 \\
(0.050)\end{array}$ \\
\hline $\mathrm{p}(=\mathrm{CT})$ & $(0.010)$ & $(0.047)$ & $(0.069)$ & $(0.010)$ & $(0.021)$ & $(0.004)$ & $(0.024)$ & $(0.033)$ & $(0.137)$ & n.a. & n.a. & $(0.004)$ \\
\hline $\begin{array}{l}\text { Model 5Y } \\
\text { p (=0) }\end{array}$ & $\begin{array}{r}2.1 \\
(0.182)\end{array}$ & $\begin{array}{r}1.6 \\
(0.220)\end{array}$ & $\begin{array}{r}1.4 \\
(0.214)\end{array}$ & $\begin{array}{r}1.7 \\
(0.121)\end{array}$ & $\begin{array}{r}1.8 \\
(0.055)\end{array}$ & $\begin{array}{r}1.9 \\
(0.017)\end{array}$ & $\begin{array}{r}1.8 \\
(0.007)\end{array}$ & $\begin{array}{r}2.0 \\
(0.000)\end{array}$ & $\begin{array}{r}0.4 \\
(0.385)\end{array}$ & $\begin{array}{r}4.1 \\
(0.009)\end{array}$ & $\begin{array}{r}1.1 \\
(0.282)\end{array}$ & $\begin{array}{r}1.8 \\
(0.062)\end{array}$ \\
\hline $\mathrm{p}(=\mathrm{CT})$ & $(0.042)$ & $(0.095)$ & $(0.115)$ & $(0.025)$ & $(0.046)$ & $(0.006)$ & $(0.066)$ & $(0.051)$ & $(0.137)$ & n.a. & n.a. & $(0.007)$ \\
\hline $\begin{array}{l}\text { Model 10Y } \\
\mathrm{p}(=0)\end{array}$ & $\begin{array}{r}0.6 \\
(0.393)\end{array}$ & $\begin{array}{r}0.8 \\
(0.349)\end{array}$ & $\begin{array}{r}0.9 \\
(0.303)\end{array}$ & $\begin{array}{r}1.2 \\
(0.208)\end{array}$ & $\begin{array}{r}1.6 \\
(0.079)\end{array}$ & $\begin{array}{r}1.7 \\
(0.027)\end{array}$ & $\begin{array}{r}1.9 \\
(0.006)\end{array}$ & $\begin{array}{r}2.0 \\
(0.001)\end{array}$ & $\begin{array}{r}0.1 \\
(0.469)\end{array}$ & $\begin{array}{r}4.1 \\
(0.009)\end{array}$ & $\begin{array}{r}1.1 \\
(0.282)\end{array}$ & $\begin{array}{r}1.5 \\
(0.095)\end{array}$ \\
\hline $\mathrm{p}(=\mathrm{CT})$ & $(0.075)$ & $(0.191)$ & $(0.177)$ & $(0.047)$ & $(0.065)$ & $(0.016)$ & $(0.043)$ & $(0.168)$ & $(0.154)$ & n.a. & n.a. & $(0.017)$ \\
\hline $\begin{array}{l}\text { Combined } \\
\mathrm{p}(=0)\end{array}$ & $\begin{array}{r}2.0 \\
(0.198)\end{array}$ & $\begin{array}{r}1.2 \\
(0.277)\end{array}$ & $\begin{array}{r}1.4 \\
(0.226)\end{array}$ & $\begin{array}{r}1.5 \\
(0.144)\end{array}$ & $\begin{array}{r}1.7 \\
(0.060)\end{array}$ & $\begin{array}{r}1.8 \\
(0.022)\end{array}$ & $\begin{array}{r}1.9 \\
(0.005)\end{array}$ & $\begin{array}{r}2.0 \\
(0.000)\end{array}$ & $\begin{array}{r}0.1 \\
(0.469)\end{array}$ & $\begin{array}{r}4.1 \\
(0.009)\end{array}$ & $\begin{array}{r}1.1 \\
(0.282)\end{array}$ & $\begin{array}{r}1.8 \\
(0.067)\end{array}$ \\
\hline $\mathrm{p}(=\mathrm{CT})$ & $(0.050)$ & $(0.150)$ & $(0.125)$ & $(0.034)$ & $(0.053)$ & $(0.010)$ & $(0.028)$ & $(0.051)$ & $(0.154)$ & n.a. & n.a. & $(0.008)$ \\
\hline
\end{tabular}


Table A3 continued: Out-of-sample forecast evaluation, baseline results

CHF/DEM

Full sample, different forecast horizons

Different samples, 36M forecast

\begin{tabular}{|c|c|c|c|c|c|c|c|c|c|c|c|c|}
\hline & \multicolumn{8}{|c|}{ 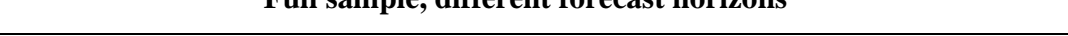 } & \multicolumn{4}{|c|}{ horizon } \\
\hline & $1 \mathrm{M}$ & $3 \mathrm{M}$ & $6 \mathrm{M}$ & $12 \mathrm{M}$ & $24 \mathrm{M}$ & $36 \mathrm{M}$ & $48 \mathrm{M}$ & $60 \mathrm{M}$ & $\begin{array}{c}1993- \\
99\end{array}$ & $\begin{array}{c}2000- \\
06\end{array}$ & $\begin{array}{c}2007- \\
10\end{array}$ & $\begin{array}{c}2011- \\
20\end{array}$ \\
\hline & \multicolumn{12}{|c|}{ Mean squared forecast error (MSFE), random walk without drift $=100$} \\
\hline Forward & 100.27 & 100.23 & 100.87 & 100.18 & 94.93 & 86.23 & 76.75 & 72.65 & 113.67 & 123.93 & 84.58 & 78.48 \\
\hline $\mathrm{p}$ & $(0.674)$ & $(0.550)$ & $(0.619)$ & $(0.518)$ & $(0.224)$ & $(0.068)$ & $(0.015)$ & $(0.007)$ & $(0.649)$ & $(0.754)$ & $(0.230)$ & $(0.003)$ \\
\hline Model 3Y & 102.31 & 107.36 & 112.48 & 119.37 & 122.90 & 122.56 & 121.09 & 118.58 & 50.94 & 131.33 & 83.14 & 140.00 \\
\hline $\mathrm{p}(\mathrm{CW})$ & $(0.725)$ & $(0.751)$ & $(0.763)$ & $(0.819)$ & $(0.873)$ & $(0.865)$ & $(0.816)$ & $(0.821)$ & $(0.004)$ & $(0.214)$ & $(0.003)$ & (1.000) \\
\hline Model 5Y & 102.06 & 106.91 & 111.12 & 114.67 & 111.90 & 109.19 & 107.41 & 104.87 & 42.95 & 101.24 & 76.57 & 126.44 \\
\hline $\mathrm{p}(\mathrm{CW})$ & $(0.737)$ & $(0.789)$ & $(0.775)$ & $(0.750)$ & $(0.607)$ & $(0.496)$ & $(0.436)$ & $(0.388)$ & $(0.003)$ & $(0.093)$ & $(0.007)$ & $(1.000)$ \\
\hline Model 10Y & 100.09 & 100.47 & 100.49 & 98.77 & 92.52 & 86.52 & 79.80 & 76.26 & 87.76 & 85.95 & 88.12 & 86.04 \\
\hline $\mathrm{p}(\mathrm{CW})$ & $(0.393)$ & $(0.431)$ & $(0.339)$ & $(0.092)$ & $(0.003)$ & $(0.000)$ & $(0.000)$ & $(0.000)$ & $(0.021)$ & $(0.035)$ & $(0.081)$ & $(0.001)$ \\
\hline Combined & 101.12 & 103.76 & 105.99 & 107.83 & 105.25 & 101.86 & 98.17 & 95.49 & 51.08 & 85.64 & 80.45 & 115.46 \\
\hline $\mathrm{p}(\mathrm{CW})$ & $(0.702)$ & $(0.749)$ & $(0.739)$ & $(0.717)$ & $(0.502)$ & $(0.262)$ & $(0.100)$ & $(0.034)$ & $(0.003)$ & $(0.011)$ & $(0.012)$ & $(0.999)$ \\
\hline
\end{tabular}

Correct sign prediction compared to the spot rate, $\%$

\begin{tabular}{|c|c|c|c|c|c|c|c|c|c|c|c|c|}
\hline $\begin{array}{l}\text { Forward } \\
\mathrm{p}\end{array}$ & $\begin{array}{r}50.6 \\
(0.942) \\
\end{array}$ & $\begin{array}{r}51.9 \\
(0.932) \\
\end{array}$ & $\begin{array}{r}48.7 \\
(0.956) \\
\end{array}$ & $\begin{array}{r}56.4 \\
(0.660) \\
\end{array}$ & $\begin{array}{r}55.2 \\
(0.860) \\
\end{array}$ & $\begin{array}{r}63.3 \\
(0.776) \\
\end{array}$ & $\begin{array}{c}78.4 \\
\text { n.o. }\end{array}$ & $\begin{array}{r}87.1 \\
\text { n.o. }\end{array}$ & $\begin{array}{r}60.7 \\
\text { n.a. }\end{array}$ & $\begin{array}{r}52.4 \\
\text { n.a. }\end{array}$ & $\begin{array}{r}56.3 \\
\text { n.a. }\end{array}$ & $\begin{array}{r}76.4 \\
(1.000) \\
\end{array}$ \\
\hline $\begin{array}{l}\text { Model 3Y } \\
\mathrm{p}\end{array}$ & $\begin{array}{r}49.4 \\
(0.449) \\
\end{array}$ & $\begin{array}{r}48.6 \\
(0.481) \\
\end{array}$ & $\begin{array}{r}47.1 \\
(0.549) \\
\end{array}$ & $\begin{array}{r}44.7 \\
(0.531) \\
\end{array}$ & $\begin{array}{r}47.5 \\
(0.454) \\
\end{array}$ & $\begin{array}{r}44.3 \\
(0.451) \\
\end{array}$ & $\begin{array}{r}41.0 \\
(0.009) \\
\end{array}$ & $\begin{array}{r}35.0 \\
(0.001) \\
\end{array}$ & $\begin{array}{r}70.2 \\
(0.000) \\
\end{array}$ & $\begin{array}{r}51.2 \\
(0.045) \\
\end{array}$ & $\begin{array}{r}70.8 \\
(0.000) \\
\end{array}$ & $\begin{array}{r}7.3 \\
(1.000) \\
\end{array}$ \\
\hline $\begin{array}{l}\text { Model 5Y } \\
\mathrm{p}\end{array}$ & $\begin{array}{r}48.3 \\
(0.631) \\
\end{array}$ & $\begin{array}{r}46.1 \\
(0.845) \\
\end{array}$ & $\begin{array}{r}45.7 \\
(0.783) \\
\end{array}$ & $\begin{array}{r}45.6 \\
(0.481) \\
\end{array}$ & $\begin{array}{r}52.8 \\
(0.018) \\
\end{array}$ & $\begin{array}{r}50.2 \\
(0.036) \\
\end{array}$ & $\begin{array}{r}49.8 \\
(0.000) \\
\end{array}$ & $\begin{array}{r}45.9 \\
(0.000) \\
\end{array}$ & $\begin{array}{r}71.4 \\
(0.000) \\
\end{array}$ & $\begin{array}{r}58.3 \\
(0.001) \\
\end{array}$ & $\begin{array}{r}81.3 \\
(0.000) \\
\end{array}$ & $\begin{array}{r}13.6 \\
(1.000) \\
\end{array}$ \\
\hline $\begin{array}{l}\text { Model 10Y } \\
\mathrm{p}\end{array}$ & $\begin{array}{r}50.0 \\
(0.646) \\
\end{array}$ & $\begin{array}{r}47.8 \\
(0.956) \\
\end{array}$ & $\begin{array}{r}48.7 \\
(0.975) \\
\end{array}$ & $\begin{array}{r}53.6 \\
(0.963) \\
\end{array}$ & $\begin{array}{r}56.0 \\
(0.324) \\
\end{array}$ & $\begin{array}{r}62.4 \\
(0.936) \\
\end{array}$ & $\begin{array}{r}78.1 \\
(0.701) \\
\end{array}$ & $\begin{array}{r}87.1 \\
\text { n.a. }\end{array}$ & $\begin{array}{r}60.7 \\
\text { n.a. }\end{array}$ & $\begin{array}{c}52.4 \\
\text { n.a. }\end{array}$ & $\begin{array}{c}56.3 \\
\text { n.a. }\end{array}$ & $\begin{array}{r}73.6 \\
(0.995) \\
\end{array}$ \\
\hline $\begin{array}{l}\text { Combined } \\
\mathrm{p}\end{array}$ & $\begin{array}{r}49.2 \\
(0.512) \\
\end{array}$ & $\begin{array}{r}46.4 \\
(0.837) \\
\end{array}$ & $\begin{array}{r}44.5 \\
(0.921) \\
\end{array}$ & $\begin{array}{r}42.7 \\
(0.946) \\
\end{array}$ & $\begin{array}{r}46.9 \\
(0.778) \\
\end{array}$ & $\begin{array}{r}53.8 \\
(0.038) \\
\end{array}$ & $\begin{array}{r}60.3 \\
(0.000) \\
\end{array}$ & $\begin{array}{r}66.7 \\
(0.000) \\
\end{array}$ & $\begin{array}{r}67.9 \\
(0.002) \\
\end{array}$ & $\begin{array}{r}71.4 \\
(0.000) \\
\end{array}$ & $\begin{array}{r}87.5 \\
(0.000) \\
\end{array}$ & $\begin{array}{r}14.5 \\
(1.000) \\
\end{array}$ \\
\hline & \multicolumn{12}{|c|}{ Correct sign prediction compared to the forward rate, \% } \\
\hline $\begin{array}{l}\text { Model 3Y } \\
\mathrm{p}\end{array}$ & $\begin{array}{r}50.8 \\
(0.583) \\
\end{array}$ & $\begin{array}{r}51.9 \\
(0.472) \\
\end{array}$ & $\begin{array}{r}48.5 \\
(0.766) \\
\end{array}$ & $\begin{array}{r}45.6 \\
(0.932) \\
\end{array}$ & $\begin{array}{r}48.7 \\
(0.970) \\
\end{array}$ & $\begin{array}{r}49.5 \\
(0.991) \\
\end{array}$ & $\begin{array}{r}49.5 \\
(0.942) \\
\end{array}$ & $\begin{array}{r}55.8 \\
(0.155) \\
\end{array}$ & $\begin{array}{r}85.7 \\
(0.000) \\
\end{array}$ & $\begin{array}{r}66.7 \\
\text { n.a. } \\
\end{array}$ & $\begin{array}{r}56.3 \\
\text { n.a. }\end{array}$ & $\begin{array}{r}6.4 \\
(1.000) \\
\end{array}$ \\
\hline $\begin{array}{l}\text { Model 5Y } \\
\mathrm{p}\end{array}$ & $\begin{array}{r}52.8 \\
(0.225) \\
\end{array}$ & $\begin{array}{r}51.9 \\
(0.532) \\
\end{array}$ & $\begin{array}{r}50.4 \\
(0.435) \\
\end{array}$ & $\begin{array}{r}45.3 \\
(0.954) \\
\end{array}$ & $\begin{array}{r}53.4 \\
(0.328) \\
\end{array}$ & $\begin{array}{r}54.7 \\
(0.353) \\
\end{array}$ & $\begin{array}{r}53.3 \\
(0.132) \\
\end{array}$ & $\begin{array}{r}56.8 \\
(0.035) \\
\end{array}$ & $\begin{array}{r}88.1 \\
(0.000) \\
\end{array}$ & $\begin{array}{r}66.7 \\
\text { n.a. } \\
\end{array}$ & $\begin{array}{r}56.3 \\
\text { n.a. }\end{array}$ & $\begin{array}{r}19.1 \\
(1.000) \\
\end{array}$ \\
\hline $\begin{array}{l}\text { Model 10Y } \\
\mathrm{p}\end{array}$ & $\begin{array}{r}52.8 \\
(0.226) \\
\end{array}$ & $\begin{array}{r}56.7 \\
(0.005) \\
\end{array}$ & $\begin{array}{r}50.7 \\
(0.395) \\
\end{array}$ & $\begin{array}{r}50.4 \\
(0.266) \\
\end{array}$ & $\begin{array}{r}57.8 \\
(0.003) \\
\end{array}$ & $\begin{array}{r}62.7 \\
(0.000) \\
\end{array}$ & $\begin{array}{r}61.6 \\
(0.000) \\
\end{array}$ & $\begin{array}{r}64.7 \\
(0.000) \\
\end{array}$ & $\begin{array}{r}76.2 \\
(0.008) \\
\end{array}$ & $\begin{array}{r}67.9 \\
(0.076) \\
\end{array}$ & $\begin{array}{r}56.3 \\
\text { n.a. }\end{array}$ & $\begin{array}{r}50.9 \\
(0.123) \\
\end{array}$ \\
\hline $\begin{array}{l}\text { Combined } \\
\mathrm{p}\end{array}$ & $\begin{array}{r}52.5 \\
(0.276) \\
\end{array}$ & $\begin{array}{r}51.4 \\
(0.665) \\
\end{array}$ & $\begin{array}{r}51.0 \\
(0.334) \\
\end{array}$ & $\begin{array}{r}44.2 \\
(0.989) \\
\end{array}$ & $\begin{array}{r}51.0 \\
(0.803) \\
\end{array}$ & $\begin{array}{r}52.9 \\
(0.787) \\
\end{array}$ & $\begin{array}{r}53.3 \\
(0.132) \\
\end{array}$ & $\begin{array}{r}56.4 \\
(0.060) \\
\end{array}$ & $\begin{array}{r}83.3 \\
(0.000) \\
\end{array}$ & $\begin{array}{r}66.7 \\
\text { n.a. } \\
\end{array}$ & $\begin{array}{r}56.3 \\
\text { n.a. }\end{array}$ & $\begin{array}{r}17.3 \\
(1.000) \\
\end{array}$ \\
\hline & \multicolumn{12}{|c|}{ Mean annualized profit, \% per year } \\
\hline $\begin{array}{l}\text { Carry trade } \\
\mathrm{p}(=0)\end{array}$ & $\begin{array}{r}0.1 \\
(0.461) \\
\end{array}$ & $\begin{array}{r}-0.1 \\
(0.525) \\
\end{array}$ & $\begin{array}{r}0.8 \\
(0.164) \\
\end{array}$ & $\begin{array}{r}0.0 \\
(0.483) \\
\end{array}$ & $\begin{array}{r}-0.1 \\
(0.599) \\
\end{array}$ & $\begin{array}{r}-0.3 \\
(0.740) \\
\end{array}$ & $\begin{array}{r}-0.3 \\
(0.815) \\
\end{array}$ & $\begin{array}{r}-0.3 \\
(0.833) \\
\end{array}$ & $\begin{array}{r}0.9 \\
(0.006) \\
\end{array}$ & $\begin{array}{r}1.1 \\
(0.003) \\
\end{array}$ & $\begin{array}{r}0.1 \\
(0.435) \\
\end{array}$ & $\begin{array}{r}-2.3 \\
(1.000) \\
\end{array}$ \\
\hline $\begin{array}{l}\text { Model 3Y } \\
\mathrm{p}(=0) \\
\mathrm{p}(=\mathrm{CT})\end{array}$ & $\begin{array}{r}-1.6 \\
(0.924) \\
(0.973) \\
\end{array}$ & $\begin{array}{r}-1.0 \\
(0.876) \\
(0.912) \\
\end{array}$ & $\begin{array}{r}-1.1 \\
(0.924) \\
(0.979) \\
\end{array}$ & $\begin{array}{r}-0.9 \\
(0.935) \\
(0.974) \\
\end{array}$ & $\begin{array}{r}-0.6 \\
(0.909) \\
(0.973) \\
\end{array}$ & $\begin{array}{r}-0.5 \\
(0.890) \\
(0.888) \\
\end{array}$ & $\begin{array}{r}-0.4 \\
(0.885) \\
(0.882) \\
\end{array}$ & $\begin{array}{r}-0.3 \\
(0.822) \\
(0.216) \\
\end{array}$ & $\begin{array}{r}1.4 \\
(0.000) \\
(0.003) \\
\end{array}$ & $\begin{array}{r}1.1 \\
(0.003) \\
\text { n.a. }\end{array}$ & $\begin{array}{r}0.1 \\
(0.435) \\
\text { n.a. }\end{array}$ & $\begin{array}{r}-3.3 \\
(1.000) \\
(1.000) \\
\end{array}$ \\
\hline $\begin{array}{l}\text { Model 5Y } \\
\mathrm{p}(=0) \\
\mathrm{p}(=\mathrm{CT})\end{array}$ & $\begin{array}{r}-0.5 \\
(0.672) \\
(0.824) \\
\end{array}$ & $\begin{array}{r}-0.6 \\
(0.746) \\
(0.821) \\
\end{array}$ & $\begin{array}{r}-0.9 \\
(0.876) \\
(0.958) \\
\end{array}$ & $\begin{array}{r}-0.8 \\
(0.904) \\
(0.944) \\
\end{array}$ & $\begin{array}{r}-0.4 \\
(0.766) \\
(0.867) \\
\end{array}$ & $\begin{array}{r}-0.4 \\
(0.819) \\
(0.735) \\
\end{array}$ & $\begin{array}{r}-0.4 \\
(0.855) \\
(0.735) \\
\end{array}$ & $\begin{array}{r}-0.3 \\
(0.813) \\
(0.153) \\
\end{array}$ & $\begin{array}{r}1.4 \\
(0.000) \\
(0.001) \\
\end{array}$ & $\begin{array}{r}1.1 \\
(0.003) \\
\text { n.a. }\end{array}$ & $\begin{array}{r}0.1 \\
(0.435) \\
\text { n.a. } \\
\end{array}$ & $\begin{array}{r}-3.0 \\
(1.000) \\
(1.000) \\
\end{array}$ \\
\hline $\begin{array}{l}\text { Model 10Y } \\
\mathrm{p}(=0) \\
\mathrm{p}(=\mathrm{CT})\end{array}$ & $\begin{array}{r}0.7 \\
(0.220) \\
(0.271) \\
\end{array}$ & $\begin{array}{r}0.7 \\
(0.192) \\
(0.200) \\
\end{array}$ & $\begin{array}{r}0.2 \\
(0.394) \\
(0.858) \\
\end{array}$ & $\begin{array}{r}0.3 \\
(0.272) \\
(0.307) \\
\end{array}$ & $\begin{array}{r}0.5 \\
(0.155) \\
(0.038) \\
\end{array}$ & $\begin{array}{r}0.3 \\
(0.234) \\
(0.027) \\
\end{array}$ & $\begin{array}{r}0.0 \\
(0.488) \\
(0.033) \\
\end{array}$ & $\begin{array}{r}-0.1 \\
(0.577) \\
(0.005) \\
\end{array}$ & $\begin{array}{r}1.0 \\
(0.003) \\
(0.057) \\
\end{array}$ & $\begin{array}{r}1.1 \\
(0.002) \\
(0.078) \\
\end{array}$ & $\begin{array}{r}0.1 \\
(0.435) \\
\text { n.a. } \\
\end{array}$ & $\begin{array}{r}-0.9 \\
(0.878) \\
(0.006) \\
\end{array}$ \\
\hline $\begin{array}{l}\text { Combined } \\
\mathrm{p}(=0) \\
\mathrm{p}(=\mathrm{CT})\end{array}$ & $\begin{array}{r}-0.5 \\
(0.690) \\
(0.852)\end{array}$ & $\begin{array}{r}-0.8 \\
(0.828) \\
(0.927)\end{array}$ & $\begin{array}{r}-0.5 \\
(0.779) \\
(0.974)\end{array}$ & $\begin{array}{r}-0.9 \\
(0.935) \\
(0.978)\end{array}$ & $\begin{array}{r}-0.5 \\
(0.832) \\
(0.954)\end{array}$ & $\begin{array}{r}-0.4 \\
(0.849) \\
(0.831)\end{array}$ & $\begin{array}{r}-0.3 \\
(0.848) \\
(0.693)\end{array}$ & $\begin{array}{r}-0.3 \\
(0.800) \\
(0.073)\end{array}$ & $\begin{array}{r}1.2 \\
(0.000) \\
(0.013)\end{array}$ & $\begin{array}{r}1.1 \\
(0.003) \\
\text { n.a. }\end{array}$ & $\begin{array}{r}0.1 \\
(0.435) \\
\text { n.a. }\end{array}$ & $\begin{array}{r}-3.0 \\
(1.000) \\
(1.000)\end{array}$ \\
\hline
\end{tabular}

Notes: The sample period includes monthly data from January 1979 to February 2020 (with a few data-driven exceptions). 
For the Japanese yen, we show two versions: one for the baseline 1979-2020 period and one for a shortened 1985-2020 period. Using the recursive estimation window, out-of-sample evaluation of forecasts was performed in the 1990-2020 period except in the last four data columns, for which the evaluation period is indicated in the heading. For MSFE, $p(C W)$ is the $\mathrm{p}$ value of testing the null hypothesis that the model MSFE is the same as that of the random walk against the onesided alternative hypothesis that the model is better, using the test of Clark and West $(2006,2007)$. The $p$ value for the sign predictions are based on the test of Pesaran and Timmermann (1992). This test assumes that both the predictor and the outcome change sign in the forecast evaluation period, which assumption is not satisfied for some of the sub-periods we consider. For the mean annualized profit, $\mathrm{p}(=0)$ is the $\mathrm{p}$ value of the null hypothesis that the Sharpe-ratio is zero against the one-sided alterative that it is positive, while $\mathrm{p}(=\mathrm{CT})$ the $\mathrm{p}$ value of the null hypothesis that the Sharpe-ratio of our model-based forecast is the same as the Sharpe-ratio of the carry trade strategy, against the one-sided alterative that the Sharpe-ratio based on our model is larger. 
Table A4 corresponds to Table 6 of the paper by showing the results for currency pairs beyond the DEM/USD rate.

Table A4: Recursive vs rolling estimation, out-of-sample forecast evaluation, mean squared forecast error (random walk $=100)$

GBP/USD Forecast horizon

\begin{tabular}{|c|c|c|c|c|c|c|c|c|c|}
\hline $\begin{array}{l}\text { estimation } \\
\text { method }\end{array}$ & $\begin{array}{l}\text { rolling } \\
\text { estimation } \\
\text { months }\end{array}$ & $1 \mathrm{M}$ & $3 \mathrm{M}$ & $6 \mathrm{M}$ & $12 \mathrm{M}$ & $24 \mathrm{M}$ & $36 \mathrm{M}$ & $48 \mathrm{M}$ & $60 \mathrm{M}$ \\
\hline \multirow{20}{*}{ rolling } & \multirow[t]{2}{*}{60} & 106.5 & 114.5 & 123.5 & 143.3 & 214.4 & 500.8 & 1543.6 & 6358.2 \\
\hline & & $(0.834)$ & $(0.767)$ & $(0.762)$ & $(0.779)$ & $(0.571)$ & $(0.588)$ & $(0.613)$ & $(0.761)$ \\
\hline & \multirow[t]{2}{*}{80} & 103.2 & 105.1 & 104.2 & 106.5 & 104.1 & 101.2 & 93.7 & 101.1 \\
\hline & & $(0.600)$ & $(0.407)$ & $(0.206)$ & $(0.135)$ & $(0.056)$ & $(0.019)$ & $(0.003)$ & $(0.006)$ \\
\hline & \multirow[t]{2}{*}{100} & 101.0 & 101.0 & 98.5 & 98.8 & 95.8 & 94.0 & 90.4 & 103.6 \\
\hline & & $(0.150)$ & $(0.073)$ & $(0.020)$ & $(0.005)$ & $(0.002)$ & $(0.001)$ & $(0.001)$ & $(0.007)$ \\
\hline & \multirow[t]{2}{*}{120} & 99.3 & 98.0 & 95.2 & 96.1 & 91.8 & 92.5 & 94.6 & 107.3 \\
\hline & & $(0.020)$ & $(0.020)$ & $(0.010)$ & $(0.005)$ & $(0.002)$ & $(0.001)$ & $(0.007)$ & $(0.051)$ \\
\hline & \multirow[t]{2}{*}{140} & 99.5 & 98.1 & 95.7 & 97.4 & 96.1 & 97.3 & 98.1 & 103.9 \\
\hline & & $(0.022)$ & $(0.013)$ & $(0.010)$ & $(0.017)$ & $(0.010)$ & $(0.012)$ & $(0.023)$ & $(0.047)$ \\
\hline & \multirow[t]{2}{*}{160} & 100.2 & 100.6 & 99.7 & 102.5 & 98.3 & 96.4 & 92.9 & 91.3 \\
\hline & & $(0.101)$ & $(0.088)$ & $(0.053)$ & $(0.090)$ & $(0.026)$ & $(0.014)$ & $(0.007)$ & $(0.003)$ \\
\hline & \multirow[t]{2}{*}{180} & 100.6 & 100.9 & 99.4 & 102.2 & 96.9 & 92.1 & 85.3 & 84.9 \\
\hline & & $(0.111)$ & $(0.068)$ & $(0.027)$ & $(0.044)$ & $(0.009)$ & $(0.002)$ & $(0.001)$ & $(0.000)$ \\
\hline & \multirow[t]{2}{*}{200} & 100.6 & 100.7 & 99.1 & 100.5 & 92.9 & 85.7 & 79.5 & 81.6 \\
\hline & & $(0.075)$ & $(0.043)$ & $(0.018)$ & $(0.021)$ & $(0.005)$ & $(0.001)$ & $(0.000)$ & $(0.000)$ \\
\hline & \multirow[t]{2}{*}{220} & 100.6 & 100.6 & 99.0 & 100.1 & 88.8 & 82.5 & 78.3 & 79.2 \\
\hline & & $(0.108)$ & $(0.066)$ & $(0.029)$ & $(0.032)$ & $(0.004)$ & $(0.001)$ & $(0.000)$ & $(0.000)$ \\
\hline & \multirow[t]{2}{*}{240} & 100.6 & 100.2 & 97.6 & 97.9 & 88.3 & 83.3 & 76.9 & 76.9 \\
\hline & & $(0.133)$ & $(0.063)$ & $(0.027)$ & $(0.034)$ & $(0.005)$ & $(0.001)$ & $(0.000)$ & $(0.000)$ \\
\hline \multirow{2}{*}{ recursive } & & 99.5 & 97.4 & 93.2 & 90.9 & 80.2 & 75.4 & 70.1 & 71.1 \\
\hline & & $(0.030)$ & $(0.011)$ & $(0.005)$ & $(0.009)$ & $(0.001)$ & $(0.000)$ & $(0.000)$ & $(0.000)$ \\
\hline
\end{tabular}


Table A4 continued: Recursive vs rolling estimation, out-of-sample forecast evaluation, mean squared forecast error $($ random walk $=100)$

\begin{tabular}{|c|c|c|c|c|c|c|c|c|c|}
\hline \multirow{2}{*}{$\begin{array}{l}\text { JPY/USD } \\
\text { estimation } \\
\text { method }\end{array}$} & \multirow[b]{2}{*}{$\begin{array}{l}\text { rolling } \\
\text { estimation } \\
\text { months }\end{array}$} & \multicolumn{8}{|c|}{ Forecast horizon } \\
\hline & & $1 \mathrm{M}$ & $3 \mathrm{M}$ & $6 \mathrm{M}$ & $12 \mathrm{M}$ & $24 \mathrm{M}$ & $36 \mathrm{M}$ & $48 \mathrm{M}$ & $60 \mathrm{M}$ \\
\hline \multirow{20}{*}{ rolling } & \multirow[t]{2}{*}{60} & 103.7 & 109.9 & 114.5 & 133.6 & 155.2 & 192.8 & 289.0 & 360.6 \\
\hline & & $(0.415)$ & $(0.482)$ & $(0.353)$ & $(0.526)$ & $(0.627)$ & $(0.628)$ & $(0.612)$ & $(0.292)$ \\
\hline & \multirow[t]{2}{*}{80} & 103.2 & 108.5 & 114.5 & 124.1 & 114.1 & 112.9 & 117.6 & 118.0 \\
\hline & & $(0.769)$ & $(0.822)$ & $(0.824)$ & $(0.815)$ & $(0.310)$ & $(0.169)$ & $(0.103)$ & $(0.038)$ \\
\hline & \multirow[t]{2}{*}{100} & 101.3 & 103.4 & 104.5 & 103.0 & 86.6 & 83.0 & 81.5 & 88.3 \\
\hline & & $(0.444)$ & $(0.460)$ & $(0.353)$ & $(0.169)$ & $(0.000)$ & $(0.000)$ & $(0.000)$ & $(0.000)$ \\
\hline & \multirow[t]{2}{*}{120} & 99.5 & 98.5 & 96.6 & 92.9 & 83.6 & 83.4 & 90.5 & 100.7 \\
\hline & & $(0.121)$ & $(0.086)$ & $(0.051)$ & $(0.020)$ & $(0.002)$ & $(0.003)$ & $(0.004)$ & $(0.005)$ \\
\hline & \multirow[t]{2}{*}{140} & 100.0 & 100.0 & 99.5 & 98.6 & 91.9 & 94.6 & 96.6 & 99.0 \\
\hline & & $(0.208)$ & $(0.177)$ & $(0.116)$ & $(0.083)$ & $(0.005)$ & $(0.001)$ & $(0.000)$ & $(0.002)$ \\
\hline & \multirow[t]{2}{*}{160} & 100.6 & 101.3 & 102.1 & 101.6 & 94.9 & 94.8 & 92.9 & 94.5 \\
\hline & & $(0.319)$ & $(0.295)$ & $(0.262)$ & $(0.166)$ & $(0.019)$ & $(0.004)$ & $(0.002)$ & $(0.002)$ \\
\hline & \multirow[t]{2}{*}{180} & 101.0 & 102.3 & 102.6 & 101.1 & 92.7 & 92.0 & 92.5 & 94.8 \\
\hline & & $(0.413)$ & $(0.406)$ & $(0.272)$ & $(0.122)$ & $(0.008)$ & $(0.002)$ & $(0.007)$ & $(0.008)$ \\
\hline & \multirow[t]{2}{*}{200} & 100.7 & 101.5 & 102.1 & 99.7 & 94.1 & 94.4 & 93.6 & 94.1 \\
\hline & & $(0.332)$ & $(0.312)$ & $(0.258)$ & $(0.109)$ & $(0.025)$ & $(0.036)$ & $(0.026)$ & $(0.018)$ \\
\hline & \multirow[t]{2}{*}{220} & 100.5 & 101.3 & 102.1 & 101.5 & 96.5 & 95.8 & 93.5 & 93.9 \\
\hline & & $(0.344)$ & $(0.338)$ & $(0.310)$ & $(0.184)$ & $(0.050)$ & $(0.053)$ & $(0.033)$ & $(0.024)$ \\
\hline & \multirow[t]{2}{*}{240} & 100.5 & 101.2 & 101.6 & 100.6 & 98.0 & 97.8 & 95.6 & 95.2 \\
\hline & & $(0.384)$ & $(0.364)$ & $(0.316)$ & $(0.187)$ & $(0.088)$ & $(0.096)$ & $(0.053)$ & $(0.037)$ \\
\hline \multirow{2}{*}{ recursive } & & 100.1 & 100.7 & 101.3 & 101.5 & 102.8 & 106.2 & 106.8 & 108.3 \\
\hline & & $(0.494)$ & $(0.664)$ & $(0.658)$ & $(0.557)$ & $(0.598)$ & $(0.766)$ & $(0.700)$ & $(0.660)$ \\
\hline
\end{tabular}


Table A4 continued: Recursive vs rolling estimation, out-of-sample forecast evaluation, mean squared forecast error $($ random walk $=100)$

\section{CHF/USD}

estimation method

Forecast horizon

$$
\text { rolling }
$$
estimation months

60 $1 \mathrm{M} \quad 3 \mathrm{M}$ $3 \mathrm{M} \quad 6 \mathrm{M}$ $12 \mathrm{M} \quad 24 \mathrm{M}$ $36 \mathrm{M}$ $48 \mathrm{M}$ $60 \mathrm{M}$ $\begin{array}{llllllll}103.1 & 112.3 & 118.6 & 130.4 & 107.9 & 80.7 & 90.6 & 105.9\end{array}$ $\begin{array}{llllllll}(0.228) & (0.510) & (0.503) & (0.602) & (0.020) & (0.000) & (0.000) & (0.000)\end{array}$

$\begin{array}{lllllllll}80 & 103.7 & 111.8 & 119.5 & 124.9 & 102.1 & 81.4 & 88.7 & 105.4\end{array}$
$\begin{array}{llllllll}(0.444) & (0.603) & (0.611) & (0.421) & (0.006) & (0.000) & (0.001) & (0.005)\end{array}$

$\begin{array}{lllllllll}100 & 101.3 & 104.4 & 107.1 & 106.5 & 89.8 & 82.1 & 96.5 & 108.5\end{array}$
$\begin{array}{llllllll}(0.196) & (0.263) & (0.208) & (0.057) & (0.001) & (0.000) & (0.002) & (0.017)\end{array}$

$\begin{array}{lllllllll}120 & 99.7 & 100.5 & 101.6 & 100.3 & 89.8 & 80.9 & 87.4 & 100.8\end{array}$
\begin{tabular}{llllllll}
$(0.034)$ & $(0.056)$ & $(0.052)$ & $(0.019)$ & $(0.005)$ & $(0.001)$ & $(0.003)$ & $(0.023)$ \\
\hline
\end{tabular}

$\begin{array}{lllllllll}140 & 100.1 & 101.6 & 103.8 & 106.1 & 94.0 & 85.6 & 95.9 & 106.4\end{array}$

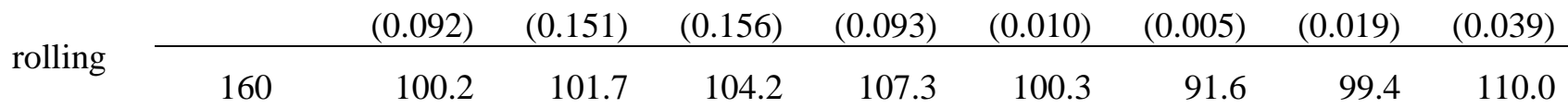

\begin{tabular}{rrrrrrrrr} 
& $(0.090)$ & $(0.139)$ & $(0.147)$ & $(0.107)$ & $(0.034)$ & $(0.014)$ & $(0.024)$ & $(0.050)$ \\
\hline 180 & 101.1 & 103.9 & 107.7 & 111.3 & 99.1 & 88.5 & 95.5 & 105.3
\end{tabular}
$\begin{array}{llllllll}(0.198) & (0.244) & (0.232) & (0.141) & (0.024) & (0.009) & (0.016) & (0.029)\end{array}$

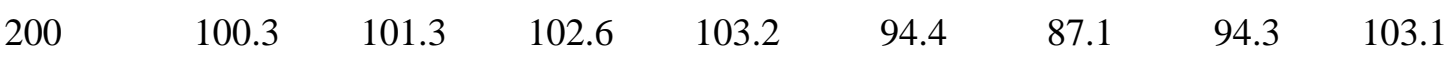
$\begin{array}{llllllll}(0.099) & (0.117) & (0.101) & (0.060) & (0.016) & (0.008) & (0.011) & (0.017)\end{array}$

$\begin{array}{lllllllll}220 & 100.2 & 101.4 & 103.2 & 105.2 & 98.3 & 90.9 & 95.8 & 102.5\end{array}$

\begin{tabular}{llllllll}
$(0.115)$ & $(0.151)$ & $(0.141)$ & $(0.091)$ & $(0.023)$ & $(0.008)$ & $(0.009)$ & $(0.013)$ \\
\hline
\end{tabular}

$\begin{array}{lllllllll}240 & 100.3 & 101.8 & 103.7 & 106.9 & 101.9 & 95.9 & 98.9 & 104.4\end{array}$

\begin{tabular}{llllllll}
$(0.139)$ & $(0.175)$ & $(0.160)$ & $(0.106)$ & $(0.027)$ & $(0.011)$ & $(0.011)$ & $(0.015)$ \\
\hline
\end{tabular}

recursive

$\begin{array}{llllllll}100.7 & 103.0 & 105.9 & 111.0 & 108.2 & 103.6 & 106.7 & 111.8\end{array}$

$\begin{array}{llllllll}(0.128) & (0.170) & (0.139) & (0.078) & (0.015) & (0.005) & (0.005) & (0.008)\end{array}$


Table A4 continued: Recursive vs rolling estimation, out-of-sample forecast evaluation, mean squared forecast error $($ random walk $=100)$

CAD/USD

estimation method

Forecast horizon

$$
\text { rolling }
$$

estimation months

60

$1 \mathrm{M} \quad 3 \mathrm{M}$

$6 \mathrm{M}$ $12 \mathrm{M}$ $24 \mathrm{M}$

$36 \mathrm{M}$

$48 \mathrm{M}$

$60 \mathrm{M}$

$\begin{array}{llllllll}102.8 & 108.0 & 109.3 & 110.5 & 111.0 & 123.3 & 133.4 & 118.0\end{array}$

$\begin{array}{llllllll}(0.447) & (0.556) & (0.441) & (0.341) & (0.177) & (0.274) & (0.312) & (0.202)\end{array}$

80

$\begin{array}{llllllll}102.7 & 107.5 & 111.9 & 120.9 & 112.3 & 119.0 & 116.6 & 125.9\end{array}$

\begin{tabular}{llllllll}
$(0.692)$ & $(0.697)$ & $(0.681)$ & $(0.765)$ & $(0.302)$ & $(0.432)$ & $(0.183)$ & $(0.383)$ \\
\hline
\end{tabular}

$\begin{array}{lllllllll}100 & 102.8 & 108.6 & 116.3 & 126.1 & 121.8 & 123.7 & 125.2 & 136.8\end{array}$

\begin{tabular}{llllllll}
$(0.725)$ & $(0.775)$ & $(0.843)$ & $(0.855)$ & $(0.598)$ & $(0.577)$ & $(0.533)$ & $(0.809)$ \\
\hline
\end{tabular}

$\begin{array}{lllllllll}120 & 103.2 & 109.4 & 117.1 & 126.7 & 122.6 & 126.5 & 129.7 & 141.5\end{array}$

\begin{tabular}{llllllll}
$(0.812)$ & $(0.828)$ & $(0.871)$ & $(0.888)$ & $(0.687)$ & $(0.764)$ & $(0.907)$ & $(0.990)$ \\
\hline
\end{tabular}

$\begin{array}{lllllllll}140 & 102.7 & 108.0 & 116.5 & 129.1 & 130.0 & 133.0 & 131.4 & 138.4\end{array}$

\begin{tabular}{|c|c|c|c|c|c|c|c|c|c|}
\hline \multirow{2}{*}{ rolling } & & $(0.736)$ & $(0.772)$ & $(0.904)$ & $(0.956)$ & $(0.916)$ & $(0.938)$ & $(0.988)$ & $(0.997)$ \\
\hline & 160 & 102.6 & 108.2 & 117.7 & 131.2 & 134.8 & 132.2 & 130.6 & 133.5 \\
\hline
\end{tabular}
\begin{tabular}{llllllll}
$(0.784)$ & $(0.853)$ & $(0.963)$ & $(0.985)$ & $(0.974)$ & $(0.959)$ & $(0.994)$ & $(0.993)$ \\
\hline
\end{tabular}

\begin{tabular}{rrrrrrrrr} 
& $(0.784)$ & $(0.853)$ & $(0.963)$ & $(0.985)$ & $(0.974)$ & $(0.959)$ & $(0.994)$ & $(0.993)$ \\
\hline \multirow{2}{*}{180} & 102.3 & 106.6 & 114.5 & 126.0 & 124.2 & 121.1 & 121.2 & 123.7 \\
& $(0.861)$ & $(0.874)$ & $(0.969)$ & $(0.988)$ & $(0.913)$ & $(0.847)$ & $(0.913)$ & $(0.916)$ \\
\hline \multirow{2}{*}{200} & 101.3 & 103.7 & 108.2 & 114.4 & 111.2 & 109.5 & 109.5 & 109.3 \\
& $(0.667)$ & $(0.673)$ & $(0.836)$ & $(0.905)$ & $(0.642)$ & $(0.548)$ & $(0.563)$ & $(0.549)$ \\
\hline \multirow{2}{*}{220} & 100.9 & 102.6 & 106.4 & 111.1 & 107.0 & 104.7 & 102.7 & 100.7 \\
& $(0.608)$ & $(0.611)$ & $(0.792)$ & $(0.850)$ & $(0.509)$ & $(0.379)$ & $(0.255)$ & $(0.196)$ \\
\hline \multirow{2}{*}{240} & 100.9 & 102.7 & 106.5 & 111.0 & 105.7 & 101.1 & 97.7 & 95.9 \\
& $(0.607)$ & $(0.621)$ & $(0.804)$ & $(0.845)$ & $(0.433)$ & $(0.212)$ & $(0.079)$ & $(0.068)$ \\
\hline & 100.5 & 101.5 & 103.5 & 105.1 & 99.4 & 95.3 & 92.5 & 90.7 \\
& $(0.317)$ & $(0.331)$ & $(0.400)$ & $(0.367)$ & $(0.107)$ & $(0.038)$ & $(0.015)$ & $(0.012)$ \\
\hline
\end{tabular}


Table A4 continued: Recursive vs rolling estimation, out-of-sample forecast evaluation, mean squared forecast error $($ random walk $=100)$

\section{AUD/USD}

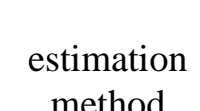

Forecast horizon

rolling

estimation months

$1 \mathrm{M}-3 \mathrm{M}$

$12 \mathrm{M} \quad 24 \mathrm{M}$

$36 \mathrm{M}$

$48 \mathrm{M}$

$60 \mathrm{M}$

60

$102.3 \quad 103.0$

99.4

93.5

83.0

77.5

72.5

74.3

$\begin{array}{llllllll}(0.396) & (0.199) & (0.065) & (0.012) & (0.000) & (0.001) & (0.000) & (0.000)\end{array}$

\begin{tabular}{rrrrrrrrrr}
\hline 80 & 101.9 & 102.3 & 100.7 & 97.9 & 85.4 & 75.8 & 71.5 & 72.7 \\
& $(0.211)$ & $(0.084)$ & $(0.041)$ & $(0.020)$ & $(0.000)$ & $(0.000)$ & $(0.000)$ & $(0.000)$ \\
\hline \multirow{2}{*}{100} & 100.5 & 100.3 & 99.8 & 96.5 & 87.4 & 77.8 & 76.9 & 84.8 \\
& $(0.075)$ & $(0.040)$ & $(0.029)$ & $(0.008)$ & $(0.001)$ & $(0.000)$ & $(0.000)$ & $(0.003)$ \\
\hline \multirow{2}{*}{120} & 100.5 & 100.5 & 99.9 & 94.4 & 85.4 & 85.6 & 89.0 & 96.3 \\
& $(0.115)$ & $(0.067)$ & $(0.049)$ & $(0.009)$ & $(0.001)$ & $(0.001)$ & $(0.004)$ & $(0.041)$ \\
\hline \multirow{2}{*}{140} & 100.0 & 99.1 & 97.7 & 94.1 & 88.6 & 89.4 & 90.2 & 94.3
\end{tabular}

rolling

\begin{tabular}{rrrrrrrrr} 
& $(0.111)$ & $(0.056)$ & $(0.040)$ & $(0.017)$ & $(0.004)$ & $(0.003)$ & $(0.009)$ & $(0.032)$ \\
\hline \multirow{2}{*}{160} & 100.1 & 99.7 & 98.6 & 94.8 & 88.8 & 87.6 & 86.8 & 88.3 \\
& $(0.138)$ & $(0.086)$ & $(0.064)$ & $(0.023)$ & $(0.004)$ & $(0.003)$ & $(0.004)$ & $(0.007)$ \\
\hline \multirow{2}{*}{180} & 99.8 & 98.6 & 96.3 & 91.8 & 85.0 & 84.1 & 82.7 & 86.1 \\
& $(0.069)$ & $(0.034)$ & $(0.022)$ & $(0.009)$ & $(0.001)$ & $(0.001)$ & $(0.002)$ & $(0.004)$ \\
\hline \multirow{2}{*}{200} & 99.6 & 98.4 & 96.1 & 92.3 & 84.1 & 81.8 & 83.1 & 87.3 \\
& $(0.067)$ & $(0.045)$ & $(0.029)$ & $(0.010)$ & $(0.001)$ & $(0.001)$ & $(0.002)$ & $(0.005)$ \\
\hline \multirow{2}{*}{220} & 99.6 & 98.6 & 96.6 & 93.0 & 84.7 & 83.4 & 83.3 & 84.1 \\
& $(0.092)$ & $(0.067)$ & $(0.045)$ & $(0.016)$ & $(0.001)$ & $(0.002)$ & $(0.002)$ & $(0.002)$ \\
\hline \multirow{2}{*}{240} & 99.6 & 98.7 & 96.6 & 93.7 & 87.8 & 86.6 & 84.5 & 84.7 \\
& $(0.096)$ & $(0.074)$ & $(0.043)$ & $(0.017)$ & $(0.002)$ & $(0.003)$ & $(0.002)$ & $(0.002)$ \\
\hline & 99.0 & 97.3 & 94.9 & 91.2 & 86.5 & 85.1 & 83.4 & 84.1 \\
& $(0.024)$ & $(0.024)$ & $(0.014)$ & $(0.003)$ & $(0.000)$ & $(0.001)$ & $(0.001)$ & $(0.001)$ \\
\hline
\end{tabular}

89.4

94.3

rolling 
Table A4 continued: Recursive vs rolling estimation, out-of-sample forecast evaluation, mean squared forecast error

$($ random walk $=100)$

NZD/USD

\begin{tabular}{|c|c|c|c|c|c|c|c|c|c|}
\hline $\begin{array}{c}\text { estimation } \\
\text { method }\end{array}$ & $\begin{array}{l}\text { rolling } \\
\text { estimation } \\
\text { months }\end{array}$ & $1 \mathrm{M}$ & $3 \mathrm{M}$ & $6 \mathrm{M}$ & $12 \mathrm{M}$ & $24 \mathrm{M}$ & $36 \mathrm{M}$ & $48 \mathrm{M}$ & $60 \mathrm{M}$ \\
\hline \multirow{20}{*}{ rolling } & \multirow[t]{2}{*}{60} & 105.3 & 113.3 & 114.2 & 118.6 & 141.0 & 185.3 & 237.8 & 288.1 \\
\hline & & $(0.765)$ & $(0.805)$ & $(0.657)$ & $(0.624)$ & $(0.924)$ & $(0.992)$ & $(0.998)$ & $(0.995)$ \\
\hline & \multirow[t]{2}{*}{80} & 101.9 & 107.2 & 109.4 & 121.3 & 145.1 & 174.9 & 206.9 & 243.2 \\
\hline & & $(0.282)$ & $(0.430)$ & $(0.370)$ & $(0.695)$ & $(0.949)$ & $(0.981)$ & $(0.983)$ & $(0.973)$ \\
\hline & \multirow[t]{2}{*}{100} & 100.9 & 104.2 & 106.9 & 114.0 & 123.6 & 131.4 & 140.0 & 149.1 \\
\hline & & $(0.174)$ & $(0.327)$ & $(0.352)$ & $(0.575)$ & $(0.743)$ & $(0.790)$ & $(0.858)$ & $(0.869)$ \\
\hline & \multirow[t]{2}{*}{120} & 100.4 & 102.7 & 104.0 & 105.7 & 110.2 & 119.5 & 127.1 & 135.5 \\
\hline & & $(0.094)$ & $(0.194)$ & $(0.166)$ & $(0.156)$ & $(0.204)$ & $(0.412)$ & $(0.531)$ & $(0.571)$ \\
\hline & \multirow[t]{2}{*}{140} & 99.8 & 100.7 & 100.5 & 101.6 & 106.2 & 114.6 & 118.4 & 121.4 \\
\hline & & $(0.054)$ & $(0.104)$ & $(0.078)$ & $(0.093)$ & $(0.156)$ & $(0.350)$ & $(0.396)$ & $(0.349)$ \\
\hline & \multirow[t]{2}{*}{160} & 100.4 & 102.3 & 103.3 & 105.0 & 106.4 & 107.7 & 107.0 & 106.4 \\
\hline & & $(0.152)$ & $(0.256)$ & $(0.232)$ & $(0.219)$ & $(0.166)$ & $(0.161)$ & $(0.122)$ & $(0.071)$ \\
\hline & \multirow[t]{2}{*}{180} & 100.5 & 102.0 & 102.1 & 102.0 & 98.1 & 95.3 & 94.1 & 95.6 \\
\hline & & $(0.143)$ & $(0.189)$ & $(0.127)$ & $(0.090)$ & $(0.027)$ & $(0.013)$ & $(0.008)$ & $(0.006)$ \\
\hline & \multirow[t]{2}{*}{200} & 100.4 & 101.5 & 101.8 & 100.0 & 92.5 & 89.4 & 88.3 & 91.2 \\
\hline & & $(0.118)$ & $(0.137)$ & $(0.105)$ & $(0.050)$ & $(0.008)$ & $(0.005)$ & $(0.003)$ & $(0.002)$ \\
\hline & \multirow[t]{2}{*}{220} & 100.5 & 101.6 & 101.7 & 100.1 & 93.9 & 90.9 & 90.3 & 92.7 \\
\hline & & $(0.127)$ & $(0.142)$ & $(0.105)$ & $(0.055)$ & $(0.011)$ & $(0.006)$ & $(0.004)$ & $(0.003)$ \\
\hline & \multirow[t]{2}{*}{240} & 100.7 & 102.2 & 102.5 & 100.9 & 94.9 & 93.4 & 92.6 & 95.4 \\
\hline & & $(0.164)$ & $(0.174)$ & $(0.125)$ & $(0.059)$ & $(0.012)$ & $(0.008)$ & $(0.006)$ & $(0.005)$ \\
\hline \multirow{2}{*}{ recursive } & & 100.7 & 102.4 & 102.4 & 101.4 & 97.2 & 96.1 & 95.6 & 98.4 \\
\hline & & $(0.126)$ & $(0.143)$ & (0.093) & $(0.045)$ & $(0.009)$ & $(0.006)$ & $(0.004)$ & (0.003) \\
\hline
\end{tabular}


Table A4 continued: Recursive vs rolling estimation, out-of-sample forecast evaluation, mean squared forecast error

$($ random walk $=100)$

NOK/USD

\begin{tabular}{|c|c|c|c|c|c|c|c|c|c|}
\hline $\begin{array}{l}\text { estimation } \\
\text { method }\end{array}$ & $\begin{array}{l}\text { rolling } \\
\text { estimation } \\
\text { months }\end{array}$ & $1 \mathrm{M}$ & $3 \mathrm{M}$ & $6 \mathrm{M}$ & $12 \mathrm{M}$ & $24 \mathrm{M}$ & $36 \mathrm{M}$ & $48 \mathrm{M}$ & $60 \mathrm{M}$ \\
\hline \multirow{20}{*}{ rolling } & \multirow[t]{2}{*}{60} & 106.2 & 113.4 & 117.9 & 124.5 & 128.2 & 124.1 & 135.2 & 132.4 \\
\hline & & $(0.864)$ & $(0.918)$ & $(0.924)$ & $(0.907)$ & $(0.676)$ & $(0.161)$ & $(0.199)$ & $(0.236)$ \\
\hline & \multirow[t]{2}{*}{80} & 103.0 & 107.6 & 110.4 & 113.6 & 118.1 & 112.9 & 114.9 & 125.9 \\
\hline & & $(0.764)$ & $(0.825)$ & $(0.722)$ & $(0.629)$ & $(0.534)$ & $(0.182)$ & $(0.122)$ & $(0.276)$ \\
\hline & \multirow[t]{2}{*}{100} & 102.7 & 107.2 & 110.9 & 117.4 & 125.1 & 122.9 & 122.8 & 126.3 \\
\hline & & $(0.656)$ & $(0.731)$ & $(0.675)$ & $(0.718)$ & $(0.723)$ & $(0.451)$ & $(0.381)$ & $(0.444)$ \\
\hline & \multirow[t]{2}{*}{120} & 103.0 & 108.0 & 112.6 & 118.8 & 120.2 & 112.0 & 106.6 & 111.4 \\
\hline & & $(0.792)$ & $(0.861)$ & $(0.855)$ & $(0.860)$ & $(0.643)$ & $(0.167)$ & $(0.032)$ & $(0.114)$ \\
\hline & \multirow[t]{2}{*}{140} & 102.6 & 106.7 & 110.4 & 113.0 & 106.7 & 100.6 & 95.4 & 94.8 \\
\hline & & $(0.792)$ & $(0.827)$ & $(0.789)$ & $(0.616)$ & $(0.099)$ & $(0.014)$ & $(0.005)$ & $(0.004)$ \\
\hline & \multirow[t]{2}{*}{160} & 101.8 & 104.9 & 107.6 & 109.9 & 106.5 & 97.1 & 89.4 & 88.0 \\
\hline & & $(0.554)$ & $(0.621)$ & $(0.545)$ & $(0.358)$ & $(0.094)$ & $(0.008)$ & $(0.002)$ & $(0.001)$ \\
\hline & \multirow[t]{2}{*}{180} & 100.7 & 101.9 & 103.0 & 102.4 & 96.1 & 85.2 & 77.4 & 77.9 \\
\hline & & $(0.237)$ & $(0.223)$ & $(0.182)$ & $(0.070)$ & $(0.008)$ & $(0.000)$ & $(0.000)$ & $(0.000)$ \\
\hline & \multirow[t]{2}{*}{200} & 100.2 & 100.6 & 101.1 & 98.1 & 88.6 & 78.2 & 72.4 & 73.5 \\
\hline & & $(0.150)$ & $(0.161)$ & $(0.143)$ & $(0.051)$ & $(0.005)$ & $(0.001)$ & $(0.000)$ & $(0.000)$ \\
\hline & \multirow[t]{2}{*}{220} & 100.2 & 100.5 & 100.6 & 97.2 & 88.3 & 79.9 & 73.8 & 71.4 \\
\hline & & $(0.196)$ & $(0.180)$ & $(0.150)$ & $(0.050)$ & $(0.006)$ & $(0.001)$ & $(0.000)$ & $(0.000)$ \\
\hline & \multirow[t]{2}{*}{240} & 100.1 & 100.2 & 100.1 & 98.2 & 92.2 & 84.7 & 77.6 & 76.2 \\
\hline & & $(0.183)$ & $(0.167)$ & $(0.141)$ & $(0.063)$ & $(0.010)$ & $(0.001)$ & $(0.000)$ & $(0.000)$ \\
\hline \multirow{2}{*}{ recursive } & & 99.6 & 98.9 & 97.4 & 93.7 & 85.9 & 76.5 & 68.6 & 66.1 \\
\hline & & $(0.119)$ & $(0.115)$ & $(0.082)$ & $(0.022)$ & $(0.001)$ & $(0.000)$ & $(0.000)$ & $(0.000)$ \\
\hline
\end{tabular}


Table A4 continued: Recursive vs rolling estimation, out-of-sample forecast evaluation, mean squared forecast error $($ random walk $=100)$

\section{SEK/USD}

\begin{tabular}{|c|c|c|c|c|c|c|c|c|c|}
\hline $\begin{array}{l}\text { estimation } \\
\text { method }\end{array}$ & $\begin{array}{l}\text { rolling } \\
\text { estimation } \\
\text { months }\end{array}$ & $1 \mathrm{M}$ & $3 \mathrm{M}$ & $6 \mathrm{M}$ & $12 \mathrm{M}$ & $24 \mathrm{M}$ & $36 \mathrm{M}$ & $48 \mathrm{M}$ & $60 \mathrm{M}$ \\
\hline \multirow{20}{*}{ rolling } & \multirow[t]{2}{*}{60} & 104.7 & 106.5 & 102.5 & 99.2 & 93.2 & 99.4 & 105.5 & 114.6 \\
\hline & & $(0.729)$ & $(0.485)$ & $(0.077)$ & $(0.022)$ & $(0.002)$ & $(0.018)$ & $(0.025)$ & $(0.033)$ \\
\hline & \multirow[t]{2}{*}{80} & 101.6 & 101.3 & 97.6 & 95.8 & 90.3 & 96.8 & 97.3 & 108.9 \\
\hline & & $(0.323)$ & $(0.122)$ & $(0.027)$ & $(0.010)$ & $(0.001)$ & $(0.011)$ & $(0.009)$ & $(0.037)$ \\
\hline & \multirow[t]{2}{*}{100} & 101.1 & 101.0 & 97.8 & 94.0 & 88.7 & 94.8 & 103.0 & 110.4 \\
\hline & & $(0.268)$ & $(0.110)$ & $(0.031)$ & $(0.005)$ & $(0.001)$ & $(0.006)$ & $(0.017)$ & $(0.049)$ \\
\hline & \multirow[t]{2}{*}{120} & 101.7 & 101.8 & 99.4 & 97.1 & 96.4 & 106.8 & 112.1 & 118.8 \\
\hline & & $(0.359)$ & $(0.133)$ & $(0.054)$ & $(0.019)$ & $(0.006)$ & $(0.042)$ & $(0.066)$ & $(0.150)$ \\
\hline & \multirow[t]{2}{*}{140} & 101.9 & 102.1 & 100.0 & 97.9 & 98.3 & 108.5 & 111.7 & 114.8 \\
\hline & & $(0.401)$ & $(0.179)$ & $(0.084)$ & $(0.028)$ & $(0.009)$ & $(0.049)$ & $(0.051)$ & $(0.045)$ \\
\hline & \multirow[t]{2}{*}{160} & 101.7 & 102.1 & 100.4 & 100.1 & 99.0 & 103.8 & 104.8 & 104.8 \\
\hline & & $(0.402)$ & $(0.212)$ & $(0.101)$ & $(0.061)$ & $(0.021)$ & $(0.018)$ & $(0.015)$ & $(0.011)$ \\
\hline & \multirow[t]{2}{*}{180} & 101.3 & 101.0 & 98.6 & 96.3 & 93.1 & 97.5 & 93.7 & 93.8 \\
\hline & & $(0.371)$ & $(0.150)$ & $(0.066)$ & $(0.025)$ & $(0.003)$ & $(0.003)$ & $(0.001)$ & $(0.001)$ \\
\hline & \multirow[t]{2}{*}{200} & 101.1 & 100.5 & 97.4 & 94.0 & 88.1 & 89.9 & 86.5 & 86.2 \\
\hline & & $(0.334)$ & $(0.134)$ & $(0.048)$ & $(0.015)$ & $(0.001)$ & $(0.001)$ & $(0.000)$ & $(0.000)$ \\
\hline & \multirow[t]{2}{*}{220} & 100.8 & 99.6 & 95.7 & 91.9 & 86.0 & 88.0 & 82.7 & 81.3 \\
\hline & & $(0.316)$ & $(0.102)$ & $(0.030)$ & $(0.008)$ & $(0.000)$ & $(0.001)$ & $(0.000)$ & $(0.000)$ \\
\hline & \multirow[t]{2}{*}{240} & 100.6 & 99.2 & 95.0 & 91.3 & 85.6 & 86.7 & 80.8 & 80.5 \\
\hline & & $(0.294)$ & $(0.085)$ & $(0.023)$ & $(0.007)$ & $(0.000)$ & $(0.000)$ & $(0.000)$ & $(0.000)$ \\
\hline \multirow{2}{*}{ recursive } & & 100.2 & 98.4 & 93.9 & 89.8 & 83.7 & 85.1 & 80.1 & 80.0 \\
\hline & & $(0.265)$ & $(0.061)$ & $(0.015)$ & $(0.004)$ & $(0.000)$ & $(0.000)$ & $(0.000)$ & $(0.000)$ \\
\hline
\end{tabular}


Table A4 continued: Recursive vs rolling estimation, out-of-sample forecast evaluation, mean squared forecast error $($ random walk $=100)$

\section{GBP/DEM}

estimation method
Forecast horizon

\begin{tabular}{|c|c|c|c|c|c|c|c|c|}
\hline $\begin{array}{l}\text { rolling } \\
\text { estimation } \\
\text { months }\end{array}$ & $1 \mathrm{M}$ & $3 \mathrm{M}$ & $6 \mathrm{M}$ & $12 \mathrm{M}$ & $24 \mathrm{M}$ & $36 \mathrm{M}$ & $48 \mathrm{M}$ & $60 \mathrm{M}$ \\
\hline \multirow[t]{2}{*}{60} & 109.8 & 116.7 & 135.6 & 210.1 & 2179.3 & 52210.8 & \#\#\#\#\#\#\#\# & \#\#\#\#\#\#\#\# \\
\hline & $(0.946)$ & $(0.790)$ & $(0.733)$ & $(0.597)$ & $(0.751)$ & $(0.842)$ & $(0.845)$ & $(0.844)$ \\
\hline \multirow[t]{2}{*}{80} & 105.4 & 108.0 & 108.7 & 108.8 & 122.5 & 161.9 & 231.8 & 431.9 \\
\hline & $(0.862)$ & $(0.529)$ & $(0.317)$ & $(0.156)$ & $(0.243)$ & $(0.659)$ & $(0.783)$ & $(0.910)$ \\
\hline \multirow[t]{2}{*}{100} & 102.6 & 104.8 & 107.0 & 106.3 & 111.9 & 134.4 & 167.9 & 248.6 \\
\hline & $(0.570)$ & $(0.344)$ & $(0.295)$ & $(0.143)$ & $(0.121)$ & $(0.420)$ & $(0.630)$ & $(0.849)$ \\
\hline \multirow[t]{2}{*}{120} & 102.7 & 104.5 & 106.0 & 105.2 & 108.2 & 125.7 & 144.1 & 191.4 \\
\hline & $(0.715)$ & $(0.443)$ & $(0.321)$ & $(0.160)$ & $(0.131)$ & $(0.453)$ & $(0.570)$ & $(0.848)$ \\
\hline 140 & 103.1 & 106.3 & 109.9 & 112.4 & 114.9 & 122.8 & 126.2 & 140.4 \\
\hline
\end{tabular}

rolling

\begin{tabular}{rrrrrrrrr} 
& $(0.849)$ & $(0.731)$ & $(0.685)$ & $(0.646)$ & $(0.593)$ & $(0.735)$ & $(0.726)$ & $(0.870)$ \\
\hline \multirow{2}{*}{160} & 102.0 & 104.6 & 106.3 & 108.0 & 108.9 & 110.1 & 111.2 & 113.7 \\
& $(0.729)$ & $(0.627)$ & $(0.493)$ & $(0.376)$ & $(0.179)$ & $(0.145)$ & $(0.106)$ & $(0.111)$ \\
\hline \multirow{2}{*}{180} & 101.1 & 102.3 & 103.2 & 103.3 & 102.8 & 101.3 & 98.8 & 102.9 \\
& $(0.467)$ & $(0.334)$ & $(0.223)$ & $(0.098)$ & $(0.020)$ & $(0.016)$ & $(0.005)$ & $(0.014)$ \\
\hline \multirow{2}{*}{200} & 100.4 & 100.5 & 100.2 & 99.2 & 96.9 & 95.5 & 98.1 & 101.7 \\
& $(0.255)$ & $(0.128)$ & $(0.079)$ & $(0.032)$ & $(0.006)$ & $(0.002)$ & $(0.003)$ & $(0.008)$ \\
\hline \multirow{2}{*}{220} & 100.0 & 99.7 & 98.4 & 96.2 & 95.9 & 97.0 & 97.4 & 99.7 \\
& $(0.146)$ & $(0.103)$ & $(0.041)$ & $(0.011)$ & $(0.005)$ & $(0.006)$ & $(0.005)$ & $(0.009)$ \\
\hline \multirow{2}{*}{240} & 100.2 & 100.0 & 99.5 & 98.3 & 95.8 & 95.0 & 94.0 & 95.0 \\
& $(0.241)$ & $(0.137)$ & $(0.092)$ & $(0.035)$ & $(0.008)$ & $(0.005)$ & $(0.004)$ & $(0.005)$ \\
\hline & 99.8 & 99.0 & 98.0 & 96.3 & 94.2 & 93.1 & 93.6 & 96.5 \\
& $(0.131)$ & $(0.063)$ & $(0.032)$ & $(0.008)$ & $(0.002)$ & $(0.004)$ & $(0.008)$ & $(0.033)$ \\
\hline
\end{tabular}


Table A4 continued: Recursive vs rolling estimation, out-of-sample forecast evaluation, mean squared forecast error $($ random walk $=100)$

\section{JPY/DEM}

estimation method

Forecast horizon

\begin{tabular}{|c|c|c|c|c|c|c|c|c|c|}
\hline \multirow{10}{*}{ rolling } & 60 & $\begin{array}{r}106.4 \\
(0.982) \\
\end{array}$ & $\begin{array}{r}115.9 \\
(0.988) \\
\end{array}$ & $\begin{array}{r}120.4 \\
(0.969) \\
\end{array}$ & $\begin{array}{r}121.8 \\
(0.915) \\
\end{array}$ & $\begin{array}{r}124.3 \\
(0.900) \\
\end{array}$ & $\begin{array}{r}125.5 \\
(0.802) \\
\end{array}$ & $\begin{array}{r}139.5 \\
(0.873) \\
\end{array}$ & $\begin{array}{r}155.4 \\
(0.810) \\
\end{array}$ \\
\hline & 80 & $\begin{array}{r}103.6 \\
(0.809) \\
\end{array}$ & $\begin{array}{r}109.3 \\
(0.860) \\
\end{array}$ & $\begin{array}{r}112.4 \\
(0.761) \\
\end{array}$ & $\begin{array}{r}114.2 \\
(0.566) \\
\end{array}$ & $\begin{array}{r}117.5 \\
(0.467) \\
\end{array}$ & $\begin{array}{r}118.2 \\
(0.348) \\
\end{array}$ & $\begin{array}{r}120.8 \\
(0.225) \\
\end{array}$ & $\begin{array}{r}120.9 \\
(0.138) \\
\end{array}$ \\
\hline & 100 & $\begin{array}{r}101.6 \\
(0.631) \\
\end{array}$ & $\begin{array}{r}105.5 \\
(0.788) \\
\end{array}$ & $\begin{array}{r}108.7 \\
(0.757) \\
\end{array}$ & $\begin{array}{r}111.7 \\
(0.677) \\
\end{array}$ & $\begin{array}{r}112.4 \\
(0.445) \\
\end{array}$ & $\begin{array}{r}108.1 \\
(0.180) \\
\end{array}$ & $\begin{array}{r}102.9 \\
(0.053) \\
\end{array}$ & $\begin{array}{r}96.2 \\
(0.021) \\
\end{array}$ \\
\hline & 120 & $\begin{array}{r}101.2 \\
(0.591) \\
\end{array}$ & $\begin{array}{r}103.1 \\
(0.612) \\
\end{array}$ & $\begin{array}{r}104.0 \\
(0.469) \\
\end{array}$ & $\begin{array}{r}103.4 \\
(0.258) \\
\end{array}$ & $\begin{array}{r}99.6 \\
(0.068) \\
\end{array}$ & $\begin{array}{r}92.1 \\
(0.004) \\
\end{array}$ & $\begin{array}{r}87.5 \\
(0.001) \\
\end{array}$ & $\begin{array}{r}82.3 \\
(0.001) \\
\end{array}$ \\
\hline & 140 & $\begin{array}{r}100.2 \\
(0.253) \\
\end{array}$ & $\begin{array}{r}101.3 \\
(0.375) \\
\end{array}$ & $\begin{array}{r}101.4 \\
(0.283) \\
\end{array}$ & $\begin{array}{r}101.3 \\
(0.203) \\
\end{array}$ & $\begin{array}{r}101.0 \\
(0.131) \\
\end{array}$ & $\begin{array}{r}100.3 \\
(0.072) \\
\end{array}$ & $\begin{array}{r}98.4 \\
(0.028) \\
\end{array}$ & $\begin{array}{r}95.8 \\
(0.018) \\
\end{array}$ \\
\hline & 160 & $\begin{array}{r}100.9 \\
(0.575) \\
\end{array}$ & $\begin{array}{r}102.7 \\
(0.637) \\
\end{array}$ & $\begin{array}{r}103.9 \\
(0.541) \\
\end{array}$ & $\begin{array}{r}105.5 \\
(0.457) \\
\end{array}$ & $\begin{array}{r}105.5 \\
(0.279) \\
\end{array}$ & $\begin{array}{r}100.0 \\
(0.046) \\
\end{array}$ & $\begin{array}{r}97.6 \\
(0.016) \\
\end{array}$ & $\begin{array}{r}93.4 \\
(0.011) \\
\end{array}$ \\
\hline & 180 & $\begin{array}{r}100.5 \\
(0.403) \\
\end{array}$ & $\begin{array}{r}101.7 \\
(0.462) \\
\end{array}$ & $\begin{array}{r}101.6 \\
(0.311) \\
\end{array}$ & $\begin{array}{r}100.4 \\
(0.166) \\
\end{array}$ & $\begin{array}{r}99.6 \\
(0.081) \\
\end{array}$ & $\begin{array}{r}93.2 \\
(0.014) \\
\end{array}$ & $\begin{array}{r}91.0 \\
(0.008) \\
\end{array}$ & $\begin{array}{r}92.7 \\
(0.026) \\
\end{array}$ \\
\hline & 200 & $\begin{array}{r}100.4 \\
(0.411) \\
\end{array}$ & $\begin{array}{r}101.4 \\
(0.453) \\
\end{array}$ & $\begin{array}{r}101.3 \\
(0.321) \\
\end{array}$ & $\begin{array}{r}98.5 \\
(0.109) \\
\end{array}$ & $\begin{array}{r}94.0 \\
(0.017) \\
\end{array}$ & $\begin{array}{r}90.8 \\
(0.008) \\
\end{array}$ & $\begin{array}{r}88.3 \\
(0.005) \\
\end{array}$ & $\begin{array}{r}86.8 \\
(0.006) \\
\end{array}$ \\
\hline & 220 & $\begin{array}{r}99.6 \\
(0.142) \\
\end{array}$ & $\begin{array}{r}99.4 \\
(0.190) \\
\end{array}$ & $\begin{array}{r}99.1 \\
(0.177) \\
\end{array}$ & $\begin{array}{r}98.4 \\
(0.115) \\
\end{array}$ & $\begin{array}{r}95.2 \\
(0.029) \\
\end{array}$ & $\begin{array}{r}91.4 \\
(0.003) \\
\end{array}$ & $\begin{array}{r}88.7 \\
(0.001) \\
\end{array}$ & $\begin{array}{r}86.8 \\
(0.002) \\
\end{array}$ \\
\hline & 240 & $\begin{array}{r}100.2 \\
(0.318) \\
\end{array}$ & $\begin{array}{r}100.6 \\
(0.309) \\
\end{array}$ & $\begin{array}{r}100.2 \\
(0.204) \\
\end{array}$ & $\begin{array}{r}98.1 \\
(0.066) \\
\end{array}$ & $\begin{array}{r}94.1 \\
(0.010) \\
\end{array}$ & $\begin{array}{r}89.6 \\
(0.002) \\
\end{array}$ & $\begin{array}{r}86.6 \\
(0.001) \\
\end{array}$ & $\begin{array}{r}83.4 \\
(0.002) \\
\end{array}$ \\
\hline recursive & & $\begin{array}{r}100.0 \\
(0.358) \\
\end{array}$ & $\begin{array}{r}100.1 \\
(0.426) \\
\end{array}$ & $\begin{array}{r}99.9 \\
(0.339) \\
\end{array}$ & $\begin{array}{r}99.4 \\
(0.261) \\
\end{array}$ & $\begin{array}{r}98.6 \\
(0.167) \\
\end{array}$ & $\begin{array}{r}96.5 \\
(0.061) \\
\end{array}$ & $\begin{array}{r}94.3 \\
(0.024) \\
\end{array}$ & $\begin{array}{r}93.9 \\
(0.032) \\
\end{array}$ \\
\hline
\end{tabular}


Table A4 continued: Recursive vs rolling estimation, out-of-sample forecast evaluation, mean squared forecast error $($ random walk $=100)$

\section{CHF/DEM}

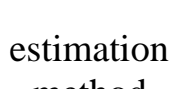
method

Forecast horizon

$$
\text { rolling }
$$

estimation months

\begin{tabular}{rrrrrrrrr}
\multirow{2}{*}{60} & 102.6 & 106.6 & 104.5 & 112.9 & 154.7 & 241.3 & 434.2 & 927.6 \\
& $(0.258)$ & $(0.156)$ & $(0.030)$ & $(0.022)$ & $(0.090)$ & $(0.044)$ & $(0.010)$ & $(0.011)$ \\
\hline \multirow{2}{*}{80} & 103.7 & 109.3 & 110.0 & 116.7 & 150.4 & 231.9 & 430.1 & 996.2 \\
& $(0.748)$ & $(0.653)$ & $(0.283)$ & $(0.133)$ & $(0.167)$ & $(0.094)$ & $(0.013)$ & $(0.008)$ \\
\hline \multirow{2}{*}{100} & 102.2 & 106.9 & 108.7 & 112.5 & 124.0 & 151.2 & 214.6 & 397.7 \\
& $(0.672)$ & $(0.675)$ & $(0.485)$ & $(0.315)$ & $(0.184)$ & $(0.067)$ & $(0.004)$ & $(0.002)$ \\
\hline \multirow{2}{*}{120} & 101.9 & 105.2 & 106.7 & 109.0 & 114.1 & 124.4 & 140.8 & 195.0 \\
& $(0.711)$ & $(0.658)$ & $(0.505)$ & $(0.332)$ & $(0.184)$ & $(0.093)$ & $(0.004)$ & $(0.000)$ \\
\hline \multirow{2}{*}{140} & 102.1 & 106.3 & 109.1 & 112.9 & 116.5 & 122.1 & 129.0 & 158.2
\end{tabular}

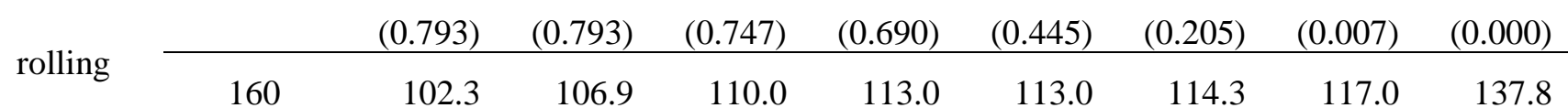

\begin{tabular}{lllllllll}
$(0.832)$ & $(0.842)$ & $(0.811)$ & $(0.731)$ & $(0.388)$ & $(0.124)$ & $(0.003)$ & $(0.000)$ \\
\hline 180 & 101.8 & 105.4 & 106.9 & 108.7 & 107.7 & 106.9 & 105.2 & 116.0
\end{tabular}

$\begin{array}{lllllllll}180 & 101.8 & 105.4 & 106.9 & 108.7 & 107.7 & 106.9 & 105.2 & 116.0\end{array}$

\begin{tabular}{llllllll}
$(0.759)$ & $(0.763)$ & $(0.651)$ & $(0.548)$ & $(0.228)$ & $(0.062)$ & $(0.001)$ & $(0.000)$ \\
\hline
\end{tabular}

\begin{tabular}{rrrrrrrrr}
\hline 200 & 102.0 & 106.0 & 108.4 & 110.4 & 107.6 & 105.6 & 102.3 & 107.6 \\
& $(0.826)$ & $(0.830)$ & $(0.788)$ & $(0.701)$ & $(0.291)$ & $(0.073)$ & $(0.001)$ & $(0.000)$ \\
\hline \multirow{2}{*}{220} & 101.2 & 103.1 & 103.8 & 104.4 & 100.7 & 97.3 & 93.3 & 91.3 \\
& $(0.706)$ & $(0.647)$ & $(0.521)$ & $(0.420)$ & $(0.101)$ & $(0.041)$ & $(0.002)$ & $(0.000)$ \\
\hline \multirow{2}{*}{240} & 101.1 & 103.4 & 104.5 & 105.8 & 105.8 & 103.9 & 98.7 & 98.1 \\
& $(0.668)$ & $(0.666)$ & $(0.573)$ & $(0.492)$ & $(0.337)$ & $(0.155)$ & $(0.005)$ & $(0.000)$ \\
\hline & 101.1 & 103.8 & 106.0 & 107.8 & 105.2 & 101.9 & 98.2 & 95.5
\end{tabular}

recursive

\begin{tabular}{llllllll}
$(0.702)$ & $(0.749)$ & $(0.739)$ & $(0.717)$ & $(0.502)$ & $(0.262)$ & $(0.100)$ & $(0.034)$ \\
\hline
\end{tabular}

Notes: The results of combined forecasts are reported, whereby three forecasts are combined with equal weights from three models using alternative maturity theoretical forward rates, 3 years, 5 years and 10 years (expect for New Zealand and Sweden, for which the 2-year maturity rate is used instead of the 3-year maturity rate). The model is defined in equation (13). The sample period includes monthly data from January 1979 to February 2020. Using either the recursive or rolling estimation windows, out-of-sample evaluation of forecasts was performed in the 1990-2020 period. p values are reported in parentheses of testing the null hypothesis that the model MSFE is the same as that of the random walk against the onesided alternative hypothesis that the model is better, based on the test of Clark and West $(2006,2007)$. 